\title{
Iraanse vluchtelingen en asielzoekers in beeld: ervaren begeleiding, psychopathologie en perceptie van kansen
}

Citation for published version (APA):

Tabesh, M. (2012). Iraanse vluchtelingen en asielzoekers in beeld: ervaren begeleiding, psychopathologie en perceptie van kansen. [, Maastricht University]. Maastricht University. https://doi.org/10.26481/dis.20121121mt

Document status and date:

Published: 01/01/2012

DOI:

10.26481/dis.20121121mt

Document Version:

Publisher's PDF, also known as Version of record

\section{Please check the document version of this publication:}

- A submitted manuscript is the version of the article upon submission and before peer-review. There can be important differences between the submitted version and the official published version of record. People interested in the research are advised to contact the author for the final version of the publication, or visit the DOI to the publisher's website.

- The final author version and the galley proof are versions of the publication after peer review.

- The final published version features the final layout of the paper including the volume, issue and page numbers.

Link to publication

\footnotetext{
General rights rights.

- You may freely distribute the URL identifying the publication in the public portal. please follow below link for the End User Agreement:

www.umlib.nl/taverne-license

Take down policy

If you believe that this document breaches copyright please contact us at:

repository@maastrichtuniversity.nl

providing details and we will investigate your claim.
}

Copyright and moral rights for the publications made accessible in the public portal are retained by the authors and/or other copyright owners and it is a condition of accessing publications that users recognise and abide by the legal requirements associated with these

- Users may download and print one copy of any publication from the public portal for the purpose of private study or research.

- You may not further distribute the material or use it for any profit-making activity or commercial gain

If the publication is distributed under the terms of Article $25 \mathrm{fa}$ of the Dutch Copyright Act, indicated by the "Taverne" license above, 
Iraanse vluchtelingen en asielzoekers in beeld:

Ervaren begeleiding, psychopathologie

en

perceptie van kansen 


\section{COLOFON}

\section{ISBN}

Druk Datawyse | Universitaire Pers Maastricht

Boekverzorging Franka van Loon

Bureauredactie Linda Slangen

Tabesh, Mahnaz. Iraanse vluchtelingen en asielzoekers in beeld:

Ervaren begeleiding, psychopathologie en perceptie van kansen

Thesis Maastricht University - With ref. - Met samenvatting in Engels

Niets uit deze uitgave mag worden vermenigvuldigd en/of openbaar gemaakt door middel van druk, fotokopie, microfilm of op welke andere wijze ook, zonder voorafgaande schriftelijke toestemming van de uitgever. 


\title{
Iraanse vluchtelingen en asielzoekers in beeld:
}

\author{
Ervaren begeleiding, psychopathologie \\ en \\ perceptie van kansen
}

PROEFSCHRIFT

ter verkrijging van de graad van doctor aan de Universiteit Maastricht, op gezag van de Rector Magnificus, prof. dr. L. Soete, volgens het besluit van het College van Decanen,

in het openbaar te verdedigen op woensdag 21 november 2012 om 16:00 uur.

door

Mahnaz Tabesh 


\section{Promotor}

Prof. dr. A. Arntz

\section{Beoordelingscommissie}

Prof. dr. M.L. Peters (voorzitter)

Prof. dr. D.A. Bernstein

Prof. dr. S.M.A.A. Evers

Prof. dr. M.J.H. Huibers

Prof. dr. I.H. Komproe 


\section{Inhoudsopgave}

Deel I: Inleiding, probleemstelling, hypothesen 7

Inleiding 8

Hoofdstuk 1. Probleemstelling, hypothesen en onderzoeksmodel 11

Hoofdstuk 2. Integratie in het perspectief van begeleiding 15

Hoofdstuk 3. Cultuurverschilen en integratie van Iraanse vluchtelingen 31

Hoofdstuk 4. De onafhankelijke variabelen: procedurele rechtvaardigheid, inspraak en vertrouwen bij de begeleiding naar integratie $\quad 51$

Deel II: De moderatoren 59

Hoofdstuk 5. Individuele en psychologische factoren als moderatoren 60

Hoofdstuk 6. Depressie als moderator 66

Hoofdstuk 7. Copingstijl als moderator $\quad 74$

Hoofdstuk 8. Algemene psychopathologie en posttraumatische stressklachten 82

Deel III: Methode 93

Hoofdstuk 9. Methode van onderzoek 94

$\begin{array}{ll}\text { Deel IV: Resultaten } & 129\end{array}$

Hoofdstuk 10. Resultaten 130

$\begin{array}{ll}\text { Deel V: Discussie } & 173\end{array}$

$\begin{array}{lll}\text { Hoofdstuk 11. Discussie } & 174\end{array}$

Summary $\quad 199$

Samenvatting $\quad 205$

$\begin{array}{ll}\text { Literatuurlijst } & 209\end{array}$

$\begin{array}{ll}\text { Dankwoord } & 229\end{array}$

$\begin{array}{ll}\text { Curriculum vitae } & 231\end{array}$

Bijlagen $\quad 233$

Afkortingenlijst $\quad 246$

Lijst met afbeeldingen (tabellen en figuren) 248

$\begin{array}{ll}\text { Begeleidingsvragenlijst (deel B) } & 250\end{array}$ 
Voor Mahwash en Faramarz, hun geloof in rechtvaardigheid en vrijheid. 
Deel I

Inleiding, probleemstelling, hypothesen 


\section{Inleiding}

In deze inleiding geef ik een kort overzicht van wat ik in deze studie betoog. Ik zet mijn onderzoeksmodel en probleemstelling uiteen en benoem mijn hypothesen die ik later in deze studie wil toetsen. Deze inleiding sluit ik af met een schematisch model dat in deze studie onderzocht wordt.

Miljoenen mensen worden gedwongen om zich te verplaatsen van de ene kant naar de andere kant van de wereld. De vluchtelingenproblematiek kent een lange geschiedenis en is meegegroeid met de sociaaleconomische ontwikkeling van de mensheid.

Sinds de afgelopen twee decennia worden de westerse landen in het bijzonder geconfronteerd met de instroom van migranten en vluchtelingen. Het karakter van migratie uit 'niet-westerse landen' is in de afgelopen decennia verschoven van arbeidsmigratie naar asielmigratie. In bijna alle Europese landen kwam het 'vluchtelingenthema' hoog op de politieke agenda te staan.

Uit de cijfers van UNHCR blijkt dat het aantal asielzoekers in de Europese Unie in 2007 gestegen is. In dat jaar kwamen in totaal 222.900 asielaanvragen binnen. In 2008 hebben 13.000 mensen in Nederland asiel aangevraagd. Het percentage asielzoekers dat voor het eerst in de periode 2007-2008 een aanvraag in Nederland heeft gedaan, steeg met $70 \%$. In de komende decennia zal de allochtone bevolking sterk blijven groeien van 3,2 miljoen op 1 januari 2007 tot 4,8 miljoen in 2050 (CBS, 2008). Twee derde van de totale bevolkingsgroei in Nederland in de afgelopen vijf jaar bestaat uit allochtonen. Volgens de gegevens van het Centraal Bureau voor de Statistiek (CBS, 2008) steeg het aandeel van niet-westerse allochtonen van 7,6\% in 1996 naar 19\% van de bevolking in 2007. In 2015 zal 14\% van de bevolking allochtoon zijn van wie 40\% uit derdewereldlanden. In 2015 is de prognose dat Nederland 3,5 miljoen allochtonen telt. De sterkst groeiende groep wordt gevormd door Aziatische asielzoekers uit landen als Irak, Iran en Afghanistan (CBS, 2004). Op 1 januari 2009 woonden er bijna 16,5 miljoen mensen in Nederland, 622.000 meer dan aan het begin van 2000. Twee derde van deze groei betreft personen van niet-westerse herkomst, waarvan Nederland er nu 1,8 miljoen telt. Dat is nu $11 \%$ van de totale bevolking. De niet-westerse bevolking is tussen 2000 en 2009 met 400.000 personen toegenomen (CBS, 2009).

Op 1 januari 2010 telde Nederland 16,6 miljoen inwoners. Ruim 11\% van de Nederlandse bevolking is van niet-westerse herkomst (1,9 miljoen personen). Eén op de vijf inwoners behoort tot de allochtone bevolking. De helft van hen is in Nederland geboren 
en behoort daarmee tot de tweede generatie. Het aandeel niet-westerse allochtonen in de totale bevolking is in de afgelopen tien jaar langzaam toegenomen. Somaliërs, Afghanen, Irakezen en Iraniërs vormen de vier grootste niet-westerse vluchtelingengroepen die voornamelijk om politieke en humanitaire redenen zijn gemigreerd (CBS, 2010). In 2010 vroegen 13.300 mensen asiel aan in Nederland. Dat is een daling ten opzichte van 2009. Het aantal asielaanvragen daalde van 3800 in het eerste kwartaal van 2010 naar 2860 in 2011 (CBS, 2011). De top 4 van landen waar asielzoekers vandaan komen, is ten opzichte van 2009 niet gewijzigd (Somalië, Irak, Afghanistan, Iran). De cijfers van het CBS laten ook zien dat in tegenstelling tot de andere drie landen, de asielaanvraag van de Iraniërs in het eerste kwartaal van 2011 met 13\% gestegen is ten opzichte van dat in 2010 (CBS, 2011).

Als subgroep van de categorie migrant kent de vluchtelingengroep een zeer heterogeen karakter. Deze groep is onderhevig aan diverse veranderingen en onderscheidt zich van de rest van de migrantengroep door de volgende kenmerken:

- Vluchtelingen verlaten hun land vanwege vervolging, geweld, oorlog en armoede.

- Ze vluchten hun land uit wegens vrees voor hun eigen leven en dat van hun families.

- Vluchtelingen hebben meestal traumatische ervaringen en/of diverse en heftige life events meegemaakt.

- Deze gebeurtenissen belemmeren vluchtelingen in hun poging zich een plaats te verwerven in het gastland.

- Ze hebben meestal weinig informatie over de cultuur en de omstandigheden van het gastland.

- Bij de groep vluchtelingen ontbreekt een ondersteunend sociaal netwerk in de migratielanden. Daardoor zijn ze in het nadeel ten aanzien van vele sociale en economische sectoren, zoals de arbeidsmarkt, gezondheidszorg en onderwijs.

- Vluchtelingen zijn niet alleen maar slachtoffers van geweld en verdrijving. Vlucht betekent ook op zoek gaan naar een beter leven. De hoop om elders weer een veilig en waardevol bestaan op te bouwen, hoort bij het vluchtproces.

- Om een waardevol bestaan in het nieuwe land op te bouwen, moeten vluchtelingen zich aanpassen aan de diverse aspecten en eisen van hun nieuwe omgeving.

- Door de ingewikkelde en moeilijke positie van vluchtelingen, verloopt het proces van integratie en/of aanpassing in de migratielanden niet altijd even gemakkelijk en is het in feite moeizaam en ingewikkeld.

In deze studie is ervan uitgegaan dat een goede en efficiënte begeleiding een groot effect heeft op het succes van het integratieproces van vluchtelingen. Naast 'officiële begeleiding' krijgen vluchtelingen gedurende hun integratieproces begeleiding en ondersteuning van diverse non-profitorganisaties en de Nederlandse bevolking. Deze vorm van begeleiding is in vele gevallen niet doelgericht en/of officieel. Deze begeleiding is in deze studie betiteld als 'niet-formele begeleiding'.

In dit proefschrift staat de subjectieve wijze waarop de Iraanse (ex-)vluchtelingen en asielzoekers hun begeleiding naar integratie ervaren centraal. Naar mijn mening heeft een 
succesvolle begeleiding één belangrijk kenmerk, namelijk het tot stand brengen van het gevoel dat vluchtelingen door de begeleiding meer kansen in de Nederlandse samenleving krijgen om een goed bestaan op te kunnen bouwen.

Mijn keuze om de Iraanse vluchtelingen te onderzoeken, is primair ingegeven door het feit dat ik zelf een Iraanse (ex-)vluchteling ben en ik me emotioneel betrokken voel bij mijn landgenoten. Daarnaast ben ik geïnteresseerd in de ontwikkelingen die vluchtelingen in Nederland doorlopen hebben.

Hoofdstuk 1 is gewijd aan de probleemstelling, de hypothesen en het onderzoeksmodel. Onderzoek 1 en 2 van deze studie hebben betrekking op de twee fasen van de opvang en het verblijf van asielzoekers en vluchtelingen in Nederland. In de eerste fase heeft de asielzoeker nog geen verblijfsvergunning. In de tweede fase beschikt de vluchteling over een verblijfsvergunning en/of de Nederlandse nationaliteit. In onderzoek 3 hebben alle respondenten een verblijfsvergunning. Ik maak wel een onderscheid tussen 'permanente en tijdelijke verblijfsvergunning'.

In hoofdstuk 2 bespreek ik de twee begrippen 'integratie en begeleiding' vanuit diverse theoretische kaders.

In hoofdstuk 3 wordt de invloed van culturele aspecten op het proces van integratie in kaart gebracht. Hier verwijs ik naar empirische studies en presenteer ik literatuurstudies. Ik geef een kort overzicht van de Iraanse cultuur en de integratie van Iraniërs in Nederland. Dit hoofdstuk is bedoeld om meer achtergrondinformatie te verschaffen die van belang kan zijn voor dit onderzoek. Het begrip cultuur is niet als een variabele in het onderzoeksmodel van deze studie meegenomen.

In hoofdstuk 4 wordt het effect van procedurele rechtvaardigheid op de wijze waarop de begeleiding naar integratie ervaren wordt in beeld gebracht en passeren diverse empirische studies de revue.

In hoofdstuk 5 bespreek ik het belang van verblijfsvergunning als een individuele variabele en als moderator.

In hoofdstuk 6, 7 en 8 bespreek ik de psychologische variabelen die als moderatoren in deze studie zijn bestudeerd, namelijk depressie, copingstijl en de posttraumatische stressstoornis. Hier wordt ook aandacht besteed aan de andere empirische studies.

Hoofdstuk 9 en 10 zijn gewijd aan de methode en de resultaten van dit onderzoek. Ik sluit deze studie af met mijn conclusies en aanbevelingen in hoofdstuk 11. 


\section{Hoofdstuk 1}

\section{Probleemstelling, hypothesen en onderzoeksmodel}

Onderzoek 1 is een correlationeel en kwantitatief onderzoek. De doelstelling van dit onderzoek is na te gaan hoe Iraanse vluchtelingen en asielzoekers hun begeleiding naar integratie in de Nederlandse samenleving ervaren en in het bijzonder of deze begeleiding in hun beleving kansen schept om hun eigen positie in Nederland te verbeteren.

Begeleiding maakt een wezenlijk onderdeel uit van het integratieproces. Onder begeleiding versta ik een interactieproces tussen begeleider en vluchteling, waarmee de vluchteling op basis van informatie die hij/zij ontvangt en met hulp van de begeleider kan kiezen uit verschillende mogelijkheden voor een weg; een weg die bij zijn/haar persoonlijke situatie past. Bij begeleiding van vluchtelingen dient men vooral te denken aan een proces van het geven van informatie, advies en ondersteuning, en ook indien nodig verwijzingen voor therapie en behandeling. Naar mijn mening dient begeleiding tot een goed resultaat te leiden. Een goede integratiebegeleiding moet uiteindelijk als effect hebben dat de integratie (eerder) slaagt. Ik ga ervan uit dat de begeleiding die niet op dit doel gericht is, tot teleurstelling, isolement en het gevoel van onzekerheid zal leiden.

Bij de analyse van de rol van de begeleiding naar integratie maak ik de volgende onderscheiden:

Ten eerste maak ik een onderscheid tussen twee fasen waarin vluchtelingen zich in Nederland bevinden.

- In de eerste fase en tijdens het verblijf in de asielzoekerscentra heeft de asielzoeker nog geen status, geen huis, geen recht op scholing en geen werk.

- In de tweede fase heeft de vluchteling als een gelijkwaardige burger van Nederland een verblijfsvergunning, recht op scholing en een woning, recht op sociale zekerheid en een uitkering, of hij/zij heeft een baan.

Bij mijn tweede onderscheid ga ik ervan uit dat de door de vluchteling ervaren integratie een langdurig proces is. Dit proces staat naar mijn mening onder invloed van twee groepen factoren:

A. De eerste groep van factoren (externe factoren) bestaat uit de begeleidingsfactoren zoals de vluchteling deze beleeft, en die te maken hebben met de wijze waarop de vluchtelingen begeleid worden. In welke mate ervaren zij dat er naar hen geluisterd wordt en dat zij inspraak krijgen in de beslissingen die over hen worden genomen? In welke mate achten zij de procedures die op hen toegepast worden eerlijk en rechtvaardig? In welke mate hebben zij vertrouwen in de wijze waarop zij worden begeleid? 
B. De tweede groep van factoren (interne factoren) bestaat uit individuele en psychologische factoren. Onder individuele factoren vallen onder andere demografische factoren zoals geslacht, leeftijd, en het beschikken over een verblijfsstatus. Als psychologische factoren onderzoek ik de mate van psychopathologie, depressie en de copingstijlen van de respondenten. Onderzocht wordt in welke mate deze factoren van invloed zijn op de perceptie van kansen die respondenten in de Nederlandse samenleving ervaren.

Uitgaande van beide groepen van factoren wordt ingegaan op vragen als: hoe kijken vluchtelingen aan tegen hun kansen in Nederland en hoe draagt de wijze waarop ze begeleid worden daaraan bij? In welke mate heeft hun persoonlijke ervaring met begeleiding invloed op hun perceptie van deze kansen?

Ten slotte wordt in deze studie ervan uitgegaan dat de integratie bevorderd wordt door begeleiding die de materiële en immateriële positie van vluchtelingen verbetert. De immateriële positieverbetering bevat alle elementen die met subjectieve beleving van integratie te maken hebben, zoals zich gelijkwaardig voelen, zich thuis voelen en zich niet gediscrimineerd voelen. De materiële positie heeft te maken met praktische aspecten van de integratie, zoals een baan hebben en lid zijn van maatschappelijke organisaties en clubs.

In figuur 1.1 komt het onderzoeksmodel van onderzoek 1 in beeld, waarin de afhankelijke en onafhankelijke variabelen van het onderzoek zijn weergegeven.

\section{De centrale vragen van onderzoek 1 heb ik als volgt geformuleerd:}

- In hoeverre en hoe hebben de vorm en de inhoud van de begeleiding invloed op de waargenomen kans dat de vluchteling zijn/haar positie in de Nederlandse samenleving verbetert?

- In hoeverre en hoe zijn de fase van integratie waarin de vluchteling zich bevindt, individuele en psychologische factoren als depressie, copingstijl en de mate van psychopathologie van invloed op de relatie tussen de ervaren begeleiding en de waargenomen kansen van de vluchteling om zijn/haar positie in de Nederlandse samenleving te verbeteren?

Steunend op de resultaten uit de literatuurstudie worden de volgende hypothesen voor onderzoek 1 geformuleerd:

- Respondenten schatten hun kansen naar positieverbetering met begeleiding hoger in dan zonder begeleiding.

- Respondenten die hun begeleiding als rechtvaardig, eerlijk en betrouwbaar ervaren en het gevoel hebben dat ze inspraak hebben in hun begeleiding, schatten hun kansen op positieverbetering hoger in.

- Het beschikken over een verblijfsvergunning heeft een positief effect op de relatie tussen kansperceptie- en de ervaren begeleidingsfactoren (rechtvaardigheid, vertrouwen, inspraak). 
- De mate van depressie en psychopathologieklachten is over het algemeen hoog en asielzoekers rapporteren meer psychopathologieklachten dan (ex-)vluchtelingen.

- Er bestaat een verschil tussen de twee groepen met betrekking tot de gehanteerde copingstijlen. Asielzoekers passen meer passieve en vermijdende copingstijlen toe dan (ex-)vluchtelingen.

- Individuele (leeftijd, geslacht en verblijfsvergunning) en psychologische factoren (algemene psychopathologie, coping en depressie) hebben een modererend effect op de relatie tussen de kansperceptie en de begeleidingsfactoren.

Deze hypothesen heb ik onderzocht door middel van het afnemen van drie standaardvragenlijsten en een zelfontworpen vragenlijst. De standaardvragenlijsten bestaan uit de volgende vragenlijsten: de Beck Depressie-vragenlijst (BDI), de Utrechtse Copingvragenlijst (UCL) en de Symptom Klachten Vragenlijst (SCL-90). Daarnaast is er een zelfontworpen 'begeleidingsvragenlijst' gebruikt.

Onderzoek 2 is een kwalitatief onderzoek. Het onderzoek is verricht door middel van een diepte-interview. In onderzoek 2 gaat mijn aandacht voornamelijk uit naar de persoonlijke ervaring van de respondenten met hun begeleiding naar integratie en hun perceptie van de kansen op positieverbetering. Er is ook aandacht besteed aan de effecten van de psychologische factoren en aspecten als cultuurverschillen, discriminatie en achtergrond van de respondenten.

Onderzoek 3 is een correlationeel en kwantitatief onderzoek. In onderzoek 3 besteed ik aandacht aan de psychologische factoren, met name posttraumatische stressstoornis. Door middel van vier vragenlijsten heb ik getracht de mate van posttraumatische stressstoornis en de algemene psychopathologie van de respondenten in kaart te brengen. Naast de UCL en de SCL-90 heb ik ook twee standaard traumavragenlijsten afgenomen: de Harvard Trauma-vragenlijst (HTQ) en de PTSD Syndrom Scale (PSS).

De vraagstellingen van onderzoek 3 heb ik als volgt geformuleerd:

- In welke mate hebben de respondenten last van psychopathologieklachten en in het bijzonder van angst- en depressieve klachten?

- Hebben de respondenten gezien hun achtergrond veel last van posttraumatische stressklachten?

- Bestaan er verschillen tussen de twee groepen (respondenten met een permanente verblijfsvergunning en respondenten met een pardonregeling) met betrekking tot de mate van psychopathologie, PTSS-klachten en hun copingstijlen?

Steunend op de resultaten uit de literatuurstudie heb ik de volgende hypothesen voor onderzoek 3 geformuleerd:

- De mate van algemene psychopathologie en PTSS-klachten is over het algemeen hoog.

- Respondenten die onder de pardonregeling vallen, hebben meer last van diverse psychopathologiesymptomen en PTSS-klachten dan respondenten met een permanente verblijfsvergunning. 
- Er bestaat een hoge correlatie tussen passieve en vermijdende copingstijlen, psychopathologieklachten en PTSS-klachten.

- Demografische factoren zoals geslacht en leeftijd hebben effect op de PTSS-klachten en op de mate van psychopathologieklachten.

Hieronder volgt het onderzoeksmodel van onderzoek 1.

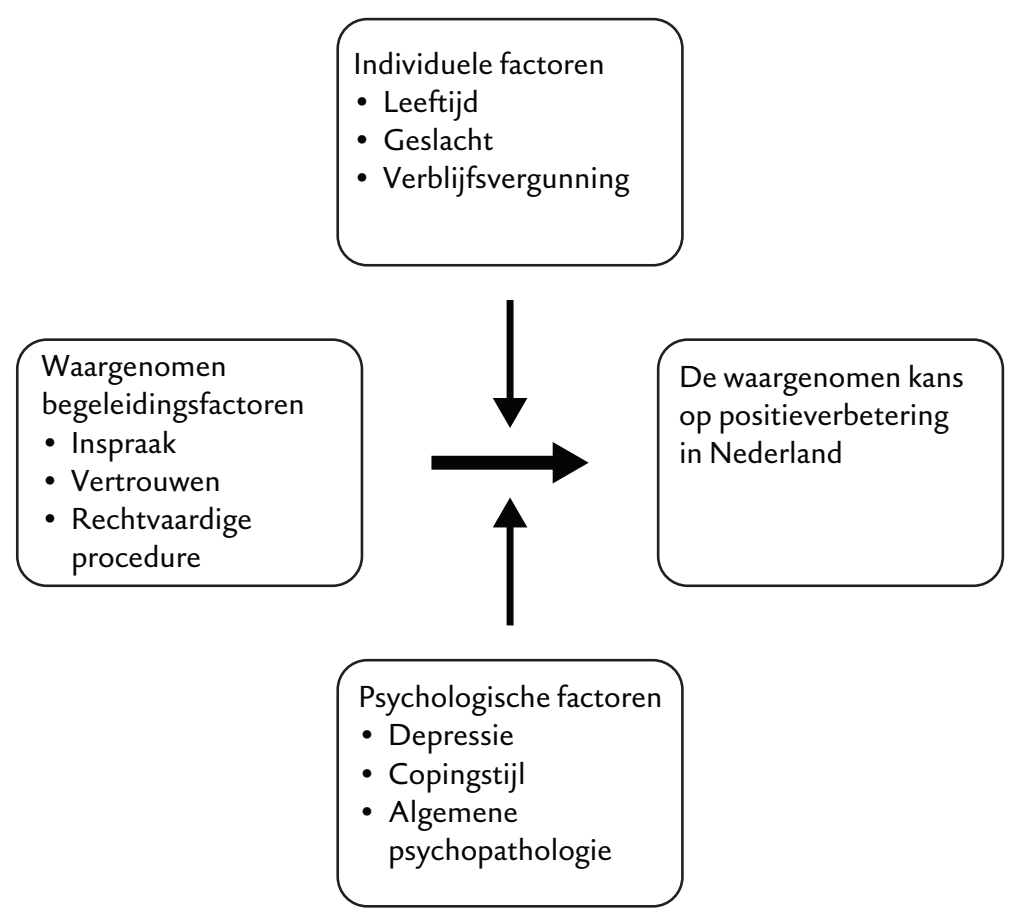

Figuur 1.1 Het onderzoeksmodel 


\section{Hoofdstuk 2}

\section{Integratie in het perspectief van begeleiding}

Het integratieproces is geen eenrichtingsverkeer, maar een interactieproces tussen de vluchteling en de samenleving met daaraan verbonden rechten en plichten. Integratie krijgt vorm langs zowel formele als informele weg. Met informele weg bedoel ik integratie in het dagelijks leven: in de bus, bij de bakker, op het schoolplein en op straat. Langs de formele weg krijgen vluchtelingen systematische begeleiding. Het doel van de formele begeleiding is de vluchteling te ondersteunen bij het opbouwen van een waardevol leven in Nederland. Het bestuderen van hoe deze begeleiding door Iraanse vluchtelingen en asielzoekers ervaren is en hoe dit de waarneming van integratiekansen beïnvloedt, staat in deze studie centraal. Begeleiding speelt een belangrijke rol bij het integratieproces en dient hoop en perspectief te bieden naar de toekomst. In dit hoofdstuk wordt eerst het begrip integratie nader beschreven. Omdat de wijze waarop begeleiding ervaren wordt per fase van het verblijf anders is, passeren de verblijfsfasen kort de revue. De definitie van begeleiding en de belangrijke aspecten van begeleiding komen aan de orde. Het hoofdstuk wordt afgesloten met een korte beschrijving van factoren die naar mijn mening het proces van begeleiding beïnvloeden.

\subsection{Integratie als begrip}

Integratie is een ingewikkeld en complex begrip. Er zijn diverse beschrijvende en verklarende definities van de term integratie. In de praktijk is het niet altijd even gemakkelijk om een duidelijk onderscheid te maken tussen integratie en andere veelgebruikte begrippen zoals aanpassing, inburgering en participatie. Nog ingewikkelder dan het begrip zelf, is de subjectieve beleving van het begrip door de nieuwkomers.

Integratie wordt gezien als de mate van deelname aan kernsituaties in de samenleving zoals de arbeidsmarkt en het onderwijs. Integratie wordt ook gezien als een voorwaarde voor een dergelijke deelname (Nekuee \& Verkuyten, 1999).

Veenman (1994) benadrukt twee aspecten van integratie: een participatieaspect en een oriëntatieaspect (formele en informele aspecten). Het eerste aspect richt zich op deelname aan maatschappelijke sectoren als onderwijs, arbeidsmarkt en ook vrijetijdsbesteding. Het tweede aspect betreft de houding die nieuwelingen hebben ten opzichte van het belang van participatie in de Nederlandse samenleving.

Engbersen \& Gabriëls (1995) spreken over een zevental sferen van integratie: arbeid, cultuur, huisvesting, onderwijs, politiek, recht en religie. De mate waarin en de wijze waarop nieuwelingen in een sfeer geïntegreerd zijn, is een indicatie voor de sociale integratie. 
Gowricharn (1997) definieert integratie in termen van 'zich thuis voelen en het gevoel van geworteld zijn'.

Vermeulen \& Penninx (1994) en Dagevos (2001) maken een onderscheid tussen structurele en sociaal-culturele integratie. De eerste omvat een volwaardige deelname aan de maatschappelijke instituties. Dit aspect slaat op arbeid, opleiding en inkomen. De tweede verwijst naar de sociale oriëntatie en culturele aanpassingen. Het gaat hier vooral om kennis van de Nederlandse taal en oriëntatie op de Nederlandse samenleving.

Integratie wordt over het algemeen beschouwd als een proces van verwerving van burgerschap en participatie in de samenleving in een drietal maatschappelijke domeinen, namelijk politiek, sociaaleconomisch en sociaal-cultureel (Penninx, 2004; Entzinger \& Biezeveld, 2003). Daarbij is sprake van een wisselwerking tussen allochtonen en autochtonen.

In deze studie staat het begrip integratie in brede zin centraal. De studie omvat zowel sociaal-culturele als structurele aspecten van integratie die ik respectievelijk immateriële en materiële integratie noem.

\subsection{Integratie in Nederland}

In Nederland is de opvang van vluchtelingen vooral gericht op structurele (materiële) integratie. Structurele integratie is het gelijkwaardig en evenredig participeren van de allochtone groepen aan alle facetten van het maatschappelijk leven. Dit wordt zichtbaar in de deelname aan maatschappelijke instituties en geledingen, variërend van arbeidsmarkt en onderwijs tot gezondheidszorg.

Om zich hier te kunnen vestigen en een nieuw bestaan op te bouwen, heeft de vluchteling ondersteuning en begeleiding nodig. Vanaf januari 1996 is in Nederland ervaring opgedaan met het zogenaamde inburgeringsbeleid. Gedurende twee jaar heeft dit beleid onder de naam 'onderwijs en welzijnsregeling inburgering nieuwkomers' vorm gekregen. Per 1 januari 1998 is de regeling vervangen door de Wet Inburgering Nieuwkomers (WIN). Het doel van het programma is om nieuwkomers zo snel mogelijk tot zelfredzaamheid in de Nederlandse samenleving te brengen. De wet moet leiden tot een goede integratie van de nieuwkomers. Begeleiding speelt bij dit programma een wezenlijke en cruciale rol. Sinds 1 januari 2007 is de Wet inburgering (Wi) van kracht. Alle vreemdelingen tussen 18 en 65 jaar die duurzaam in Nederland willen verblijven, zijn verplicht tot inburgering.

Op één uitzondering na, namelijk de studie van Van den Tillaart et al. (2000), heb ik geen uitgebreide studie gevonden naar de individuele beleving van vluchtelingen van het integratieproces. In hun studie onderzochten de auteurs in hoeverre vluchtelingen zich thuis voelen en in welke mate ze zich geïntegreerd voelen in Nederland.

Er bestaan wel diverse Nederlandse en internationale studies over vluchtelingen met betrekking tot een bepaalde sociaal-maatschappelijke sector en/of beleid. Zo zijn er studies verricht met betrekking tot de volgende terreinen:

- Arbeidsmarkt: Brink et al., 1996; Pen \& Tissing, 2000; Halewijn Staal, 1997; Berg et al., 1997; Lam, 2002; Snel, 2003. 
- Onderwijs: Prins \& Van der Linden, 1999; Goyani \& Halberstadt, 1994.

- Gezondheidszorg: Bliatout et al., 1985; Gong-Guy et al., 1991; Hondius \& Van Willigen, 1992; De Jong, 1996; Regina \& Brook, 1997; Jahanara Darabi, 1997; Nekuee \& Verkuyten, 1999; Shrestha et al., 1998; Keyes, 2000; Seeleman et al., 2005; Joels, 2008; Van Willigen (2003); Bean et al., 2006; Lindencrona et al., 2008; Toar et al., 2009; Oostrum et al., 2011.

- Integratie en acculturatieaspecten: Brink, 1997; Postel \& Boekhoorn, 1993; Cornelis et al., 1997; Koser, 1997, Besjes et al., 1998; Hooge, 1995; Vermeulen \& Penninx, 1994; Chavoushi, 1996; Budding, 1998; Snel \& Boonstra, 2005; Cornelis et al., 1997; Postel \& Boekhoorn, 1993; Nekuee \& Verkuyten, 1999; Birman \& Trickett, 2001; Bourhis et al., 1997a; Penninx \& Schrover, 2002; Silove \& Ekblad, 2002; Phalet, 2003; Scheepers et al., 2004; Gijsberts \& Dagevos, 2004 \& 2009; Klaver et al., 2005; Azghari, 2005; Van Elk, 2005; Snel \& Boonstra, 2005; Ghorashi, 2006; Michalowski et al., 2006; Muskens-Lepelstraat, 2008; De Feijter, 2008; Dagevos, 2008.

Uit deze studies blijkt dat migranten en vluchtelingen aan het begin van de 21 ste eeuw nog niet in gelijke mate als autochtonen toegang hebben kunnen verkrijgen tot onderwijs, arbeidsmarkt en gezondheidszorg. De allochtonengroep loopt op diverse gebieden achterstand op. Hoewel uit het laatste rapport van het Centraal Bureau voor de Statistiek (CBS) uit 2010-2011 blijkt dat de achterstand is verminderd, is deze nog niet helemaal ingehaald. Een voorbeeld hiervan is de werkloosheid onder de niet-westerse allochtonen. Ondanks het feit dat in de laatste jaren de werkloosheid onder migranten is afgenomen van $20 \%$ in 1997 tot $13 \%$ in 2007, is het aantal werklozen onder allochtonen gemiddeld driemaal hoger dan onder autochtonen. In 2010 was 12,6\% van de niet-westerse allochtonen werkloos. Onder autochtonen lag de werkloosheid op 4,5\%.

In de studie van Van den Tillaart et al. (2000) krijgt vooral de individuele beleving van vluchtelingen in brede zin de aandacht. In hun studie is nagegaan hoe vluchtelingen uit verscheidene landen, waaronder Iran, hun situatie in Nederland beleven. Het blijkt dat bijna de helft van de geïnterviewde Iraniërs zich goed tot zeer goed thuis voelt in Nederland. Vrijwel alle Iraanse deelnemers voelen zich veilig tot zeer veilig in Nederland. Bijna twee derde beoordeelt zijn/haar gezondheid als goed of zeer goed en bijna hetzelfde percentage is tevreden over het leven in Nederland. Er zijn evenveel Iraniërs ontevreden als tevreden over de ondersteuning die zij krijgen om zich thuis te voelen.

\subsection{Fasen bij het integratieproces}

Integratie is een langdurig en doorlopend proces. Integratie dient ertoe te leiden dat mensen volwaardig deel kunnen nemen aan de maatschappij, zich thuis en geworteld voelen en kansen zien om de eigen positie te verbeteren en dit ook daadwerkelijk doen. ledere vluchteling die zijn toevlucht tot Nederland zoekt, doorloopt diverse fasen voordat hij/zij geïntegreerd is. 
In 1989 werd door de Wetenschappelijke Raad voor het Regeringsbeleid (WRR) een advies uitgebracht waarin werd benadrukt dat bij het integratieproces vooral meer accent dient te worden gelegd op 'onderwijs en arbeid'. Begin jaren negentig kwam het inburgeringsbeleid tot stand. Alle nieuwkomers en onder anderen vluchtelingen hebben op basis van dit beleid rechten, maar ook plichten. Het beleid heeft eindelijk geleid tot de Wet Inburgering Nieuwkomers (WIN), waarin de wederzijdse rechten en plichten verwoord zijn. De inburgeringswet moest leiden tot betere integratie van alle nieuwkomers. Sinds 1 januari 2007 is de Wet inburgering (Wi) van kracht.

In deze studie maak ik een onderscheid tussen twee fasen. Dit onderscheid is gebaseerd op het 'in het bezit zijn van een verblijfsvergunning.' Het onderscheid vind ik vooral belangrijk gezien het feit dat bij iedere fase vluchtelingen zich in een andere sociaalpsychologische, juridische en economische situatie bevinden.

\section{Fase 1: opvang van asielzoekers door de rijksoverheid}

Mensen die naar Nederland vluchten, kunnen aan de Nederlandse regering bescherming vragen door het indienen van een asielverzoek. De huidige asielprocedure valt uiteen in twee procedures, namelijk de AC-procedure in aanmeldcentra en de OC- of vervolgprocedure in oriëntatie- en inburgeringscentra. Bij aankomst in Nederland dient een asielzoeker voor zichzelf en zijn/haar gezinsleden een asielaanvraag in te dienen bij de Immigratie- en Naturalisatiedienst (IND). Asielzoekerscentra vallen onder de verantwoordelijkheid van de Immigratie- en Naturalisatiedienst van het ministerie van Justitie. De AC-procedure, ook wel de 48 uurs-procedure genoemd, is een versnelde procedure. In het aanmeldcentrum moeten de asielzoekers een officieel verzoek indienen en geregistreerd worden. Tijdens de AC-procedure wordt de asielzoeker tweemaal gehoord. Hier wordt onderscheid gemaakt tussen kansrijke en kansloze asielzoekers. Kansrijke asielzoekers worden vervolgens overgeplaatst naar een Opvang- en Onderzoekscentrum (OC). Indien gedurende de AC-procedure duidelijk wordt dat deze niet binnen 48 werkuren kan worden afgerond, dan wordt ze opgeschort en wordt de asielzoeker gehuisvest in een oriëntatie- en inburgeringscentrum (OC). De OC-procedure dient volgens de regelgeving binnen zes maanden te worden afgerond. In de praktijk blijkt dat echter vaak veel langer te duren. Als de asielaanvraag wordt afgewezen in de OC-procedure, kan de asielzoeker in beroep gaan.

In deze fase is het Centraal Orgaan opvang asielzoekers (COA) verantwoordelijk voor de opvang. In de centra van het COA verblijven asielzoekers gedurende de procedure in afwachting van hun uitplaatsing naar gemeentes. Binnen een paar maanden komt er een voorlopige beslissing op de asielaanvraag. Asielzoekers die een positieve beschikking krijgen, mogen in Nederland blijven en krijgen een verblijfsvergunning. Asielzoekers die voorlopig in Nederland mogen blijven en de tweede beslissing hier mogen afwachten, blijven in een asielzoekerscentrum (azc). Hier wordt in veel gevallen de definitieve beslissing genomen. Dit kan nog enkele jaren in beslag nemen. Het COA beschikt over circa 60 opvanglocaties verspreid over acht clusters in Nederland. 
Activiteiten in het kader van dagstructurering tijdens het verblijf in de centrale opvang zijn gericht op twee mogelijke opties:

A) het bevorderen van integratie na statusverlening;

B) het niet bevorderen van integratie en gericht op terugkeer.

De gedachte achter de activiteiten in het kader van 'dagstructurering' is dat bij eventuele terugkeer naar eigen land, ook de positie in het land van herkomst bevorderd wordt. Een reëel beeld vormen van de mogelijkheden voor een toekomst in Nederland is in deze fase van groot belang.

Gedurende de opvangperiode worden asielzoekers door het COA begeleid volgens de methodiek'trajectbegeleiding asielzoekers'. Trajectbegeleiding beoogt de instroom te zijn door middel waarvan asielzoekers in staat worden gesteld zich een realistisch toekomstbeeld te vormen: een basis voor haalbare toekomstplannen. Asielzoekers worden door de trajectbegeleider geconfronteerd met de mogelijke uitkomsten van de asielprocedure en gestimuleerd om een toekomst in Nederland of elders vorm te geven. Ter ondersteuning wordt een dossier opgebouwd waarin alle relevante gegevens over de opleidings- en arbeidsachtergrond worden verzameld, en ook de activiteiten die ondernomen zijn in de centrale opvang. Het dossier wordt bij een beslissing op de asielaanvraag overgedragen aan de asielzoekers, zodat het kan worden gebruikt als input voor de inburgering. In deze fase wordt dus een beperkt programma (trajectbegeleiding asielzoekers) aan asielzoekers geboden. Het leren van de Nederlandse taal en oriëntatie op de Nederlandse samenleving is mogelijk, maar deze oriëntatie is beperkt. Tijdens het verblijf in azc's krijgen asielzoekers een kleine toelage als zakgeld en ze wonen in gemeenschappelijke ruimtes. Het recht op voorzieningen is beperkt. In deze fase heeft de asielzoeker nog geen status en daardoor ook geen recht op een eigen woning, werken en studeren. Een beperkt aantal asielzoekers die door de Stichting voor Vluchteling-Studenten (UAF) als cliënt geaccepteerd worden, krijgt financiële ondersteuning en mag een studie volgen in het hoger onderwijs. Deze groep vormt maar een klein onderdeel van het geheel.

In 1987 is de Regeling Opvang Asielzoekers (ROA) in werking getreden. Gemeenten waren verantwoordelijk voor huisvesting en integratie van asielzoekers. Tot het jaar 1996 was het voor asielzoekers mogelijk om met de hulp van gemeenten tijdelijk een (ROA-) woning te krijgen. Hoewel in 1996 de ROA-regeling is opgeheven, zit een groep vluchtelingen nog steeds in deze woningen in afwachting van de definitieve beslissing van de IND. Behalve asielzoekers die van deze regeling gebruikmaken, zijn er ook asielzoekers die intrekken bij hun familie die al in Nederland woonachtig is, of die zelf over voldoende middelen beschikken om in de noodzakelijke kosten van levensonderhoud te voorzien. In deze fase wordt de integratie niet 'bewust' aangemoedigd. Asielzoekers volgen (zeer) beperkt de Nederlandse lessen, ze ontvangen een COA-uitkering en ze mogen niet langer dan drie maanden werken. 


\section{Fase 2: opvang van statushouders}

In fase 2 bevinden zich vluchtelingen die in het bezit zijn van een verblijfsvergunning. In deze studie vallen onder deze fase alle vluchtelingen die een vluchtelingenstatus hebben of op humanitaire gronden een verblijfsvergunning in hun bezit hebben. ledereen die een D-document (voorlopige verblijfsvergunning) heeft, valt ook onder fase 2 . Bij inwilliging van het asielverzoek wordt in het OC in afwachting van huisvesting in een gemeente een start gemaakt met de inburgeringscursus. Deze is afgestemd op de Wet Inburgering (WIN, WI).

Sinds 1 januari 1996 is een nieuw verplicht inburgeringsprogramma (traject) ingesteld in de vorm van een contract. Het niet volgen van het programma zou ertoe leiden dat de vluchteling een boete krijgt in de vorm van een financiële sanctie. Het inburgeringsprogramma houdt wederzijdse verplichtingen in. De gemeenten zijn verantwoordelijk om op een optimale wijze voor voorzieningen te zorgen. Het doel van het inburgeringsprogramma is 'het stimuleren van zelfredzaamheid van nieuwkomers in sociale, educatieve en professionele aspecten'. Met het programma zouden aan de statushouders kansen en mogelijkheden worden geboden om als gelijkwaardige inwoners in Nederland een zelfstandig bestaan op te bouwen. Dit betekent dat ze naar de arbeidsmarkt worden begeleid en bemiddeld. Zij mogen ook werken. Het COA geeft vanaf eind 2002 aan iedere (nieuwe) statushouder zijn trajectdossier mee bij het vertrek uit de centrale opvang. In samenwerking met de 'taskforce inburgering' wordt bekeken welke informatie in het trajectdossier beschikbaar moet zijn aan het begin van het inburgeringsprogramma.

Daarnaast worden de lokale bij inburgering betrokken partijen op de hoogte gebracht van het bestaan van dit dossier, zodat zij er gebruik van kunnen maken. Mensen die onder deze fase vallen, hebben een status, recht op eigen woning, scholing en werk. Zij wonen meestal in gehuurde woningen, maar ze hebben doorgaans nog geen baan. Deze groep van vluchtelingen woont niet meer in azc's. Een groot deel van deze groep woont al langer dan 5 jaar in Nederland. Deze groep heeft over het algemeen een inburgeringstraject en/ of de scholing afgerond en kan zelfstandig in zijn/haar levensonderhoud voorzien. Deze nieuwe Nederlanders zijn niet meer afhankelijk van de uitkering als ze een baan hebben: verondersteld wordt dat ze zijn ingeburgerd en geïntegreerd. Voor mensen die in Nederland aanspraak willen maken op een status als vluchteling, zijn toelatingseisen neergelegd in de Vreemdelingen Wet 2000. De Wet Inburgering Nederland regelt de inburgeringseisen waaraan migranten na toelating moeten voldoen. Inburgering krijgt in Nederland in de regel verplicht een vervolg: het inburgeringsexamen waarvan de eindtermijn is vastgelegd in de Wet Inburgering. De gemeenten voeren de Wet Inburgering uit. Voornaamste taken zijn de werving van inburgeraars, het handhaven van de inburgeringsplicht en het aanbieden van inburgeringsvoorzieningen. In de afgelopen periode zijn binnen het inburgeringsbeleid maatregelen genomen om inburgering nadrukkelijk in de context van maatschappelijke en arbeidsmarktparticipatie te brengen, onder meer via de introductie van daarop toegespitste examenprofielen en het (financieel) stimuleren van gecombineerde leer-werktrajecten. 
Sinds 1 januari 2007 is de Wet inburgering (Wi) van kracht. Alle vreemdelingen tussen 18 en 65 jaar die duurzaam in Nederland willen verblijven, zijn verplicht tot inburgering. Deze plicht geldt zowel voor vreemdelingen die zich vanaf 2007 in Nederland vestigden, als voor vreemdelingen die daarvoor al in Nederland woonden maar de Nederlandse taal niet of slechts gebrekkig beheersen. Alleen voor vreemdelingen uit lidstaten van de Europese Unie (EU) of de Europese Economische Ruimte (EER) geldt een uitzondering. Daarnaast heeft de rechter recentelijk beslist dat ook Turken in Nederland niet inburgeringsplichtig zijn.

Nieuw aan de Wi was de eigen verantwoordelijkheid van inburgeraars. Zij werden geacht zelf te bepalen hoe zij zich op een examen voorbereiden en ook zelf de kosten te dragen. Wie dat niet kon betalen, kon een lening krijgen als tegemoetkoming in de cursuskosten. Ook de rol van de gemeenten veranderde. Waren zij ten tijde van de WIN een belangrijk contactpunt tussen inburgeraar en instanties als het ROC en Inburgering in Nederland, in de Wi was de bemoeienis van de gemeenten beperkt. Het was de bedoeling dat zich een markt van taalaanbieders zou ontwikkelen waardoor de inburgeraar zou kunnen kiezen uit een geschikt aanbod. Uitzonderingen waren vluchtelingen en geestelijk bedienaren; zij kregen van de gemeente wel altijd een inburgeringscursus aangeboden. Inburgeraars dienden binnen drieënhalf jaar aan de inburgeringsplicht te hebben voldaan. Ook kunnen gemeenten sinds 1 januari 2009 een inburgeringsaanbod verplichtend opleggen. Dit houdt in dat een inburgeringsaanbod kan worden vastgesteld, zonder dat de kandidaat daarmee hoeft in te stemmen. Deze bevoegdheid treedt overigens pas in werking als de gemeentelijke verordening op dit punt is aangepast. Daarnaast zijn er maatregelen genomen voor het rendement van inburgering. Meer maatwerk is belangrijk, vooral door gecombineerde of duale trajecten aan te bieden. Dit betekent dat het leren van de taal direct gekoppeld wordt aan het participeren in de samenleving, bijvoorbeeld door werk, ondernemerschap of opvoedingsondersteuning (Gijsberts et al., 2012).

In onderzoek 1 heb ik de opvang van asielzoekers en (ex-)vluchtelingen in de twee bovengenoemde fasen verdeeld. Deze indeling vind ik belangrijk gezien de verschillende ervaringen die vluchtelingen met de begeleiding naar de integratie hebben. Elke fase heeft een eigen karakter. Beperkingen of faciliteiten, waar mensen in iedere fase mee te maken krijgen, kunnen invloed uitoefenen op de persoonlijke beleving van de integratie en daardoor op de waargenomen kansen in Nederland.

\subsection{Inburgeringsprogramma voor de statushouders}

In 1998 is de Wet Inburgering Nieuwkomers (WIN) in werking getreden met als doel nieuwe migranten in Nederland beter op de Nederlandse samenleving toe te rusten, in termen van de WIN: een eerste stap in de richting van sociale, educatieve en/of professionele zelfredzaamheid. 
De WIN heeft tot doel een gericht programma te geven dat op het individu is toegespitst en de integratie van de statushouders stimuleert. Het volgen van het programma is verplicht en krijgt gestalte in de vorm van een contract. Zo wordt dus doelbewust en gericht gestreefd naar een effectief en efficiënt integratieprogramma.

Het doel van het inburgeringstraject is het stimuleren van zelfredzaamheid van nieuwkomers op sociale, educatieve en professionele aspecten, waarbij de beheersing van de taal en kennis van de arbeidsmarkt steeds belangrijker wordt. Sociale zelfredzaamheid is het minimumniveau dat elke nieuwkomer moet bereiken om zelfstandig in de Nederlandse maatschappij te kunnen functioneren. Van educatieve zelfredzaamheid is sprake als toegang verkregen kan worden tot vervolgonderwijs. Professionele zelfredzaamheid is bereikt wanneer een nieuwkomer is ingeschreven als werkzoekende bij arbeidsintegratiebureaus en op korte termijn bemiddelbaar is naar werk.

Het inburgeringsprogramma bestaat uit een welzijnscomponent en een educatieve component. De welzijnscomponent omvat de organisatie van de welzijnsprogramma's, de maatschappelijke begeleiding en de trajectbegeleiding in de gemeenten. In iedere gemeente is een bureau 'Nieuwkomers' dat de intake, doorverwijzing en trajectbegeleiding op zich neemt.

Om het doel van het inburgeringsbeleid te bereiken, wordt een individueel traject uitgestippeld. Individueel maatwerk is een startprogramma en staat centraal bij inburgeringsbeleid. Met maatwerk krijgt iedere nieuwkomer een programma op maat en toegespitst op zijn/haar persoonlijke en individuele behoeften en kwaliteiten.

Sinds 1 januari 2007 is de Wet inburgering (Wi) van kracht. Alle vreemdelingen tussen 18 en 65 jaar die duurzaam in Nederland willen verblijven, zijn verplicht tot inburgering. Met de introductie van een verplicht inburgeringsexamen heeft de overheid de mogelijkheid om inburgeraars die niet voor het examen slagen een sanctie op te leggen. Onder de WIN waren eveneens sancties mogelijk, maar deze hadden betrekking op deelname aan trajecten. De sancties in het kader van de Wi liggen zowel in de financiële als in de verblijfsrechtelijke sfeer. Wie niet binnen de gestelde termijnen voor het examen slaagt, krijgt een bestuurlijke boete die kan oplopen tot maximaal 1000 euro. De verblijfsrechtelijke gevolgen hebben betrekking op de kans op een verblijfvergunning (voor onbepaalde tijd of voor voortgezet verblijf) of op naturalisatie tot Nederlands staatsburger. In deze gevallen moet men de inburgeringstoets met succes afleggen. Inburgeren is dus sinds 2007 geen vrijblijvende aangelegenheid meer (Gijsberts et al., 2012).

\subsection{De invloed van het overheidsbeleid op de integratie}

Migratie is een adaptatieproces, waarbij zowel de migrant als het gastland betrokken is. Migratie wordt gezien als een proces van veranderingen van twee kanten dat tot stand komt wanneer twee etnoculturele groepen met elkaar in contact komen (Bourhis et al., 1997a). Het politieke systeem van het gastland is nauw betrokken bij het adaptatieproces 
en heeft grote invloed op het integratieproces. Zowel migranten als de bevolking van het land hebben invloed op het migratiebeleid en de beslissingen die regeringen nemen. Het politieke systeem van een land heeft op de volgende wijze invloed op de wijze van integratie van nieuwkomers: het politieke systeem neemt beslissingen over het type, de nationaliteit en de achtergrond van migranten die worden binnengelaten. Het systeem neemt een beslissing in verband met de mate van ondersteuning en middelen die migranten ter beschikking krijgen, om in het nieuwe land beter te kunnen integreren (Elbaz \& Helly, 2000).

Adaptatieproblematiek die door migranten ervaren wordt, kan leiden tot spanning tussen de migrantengroep en de dominante groep. Om dit te voorkomen, stelt de overheid faciliteiten en middelen ter beschikking van de nieuwkomers om het adaptatieproces te bevorderen. In sommige gevallen hebben migranten en de dominante groep overeenstemming over de wijze en de soort van adaptatiestrategie, terwijl ze in andere gevallen volstrekt tegenovergestelde of vage ideeën hebben over het adaptatieproces. Omdat het proces van besluitvorming een zeer gevoelige aangelegenheid is, dient het politieke systeem op basis van uitgebreide onderzoeken plannen te maken en periodiek door middel van evaluatieonderzoeken de mate van succes en de effectiviteit van het beleid objectief te meten. Dit leidt tot het opstellen en uitvoeren van een effectiever migratiebeleid.

In een moderne samenleving is het migratiebeleid gebaseerd op twee parameters:

- Externe grenzen van de staat. De externe grenzen worden bepaald door internationale regels die voor een groot deel uitmaken wie als vreemdeling én wie als een gelijke burger wordt beschouwd. Hiervoor doet men een beroep op de conventie van Den Haag van 1930.

- Interne grenzen van de staat die bepalen wie kan en moet worden toegelaten als migrant. Interne grenzen omvatten de volgende aspecten:

- Open of gesloten zijn van de grenzen voor migranten.

- De mate waarin migranten worden toegelaten.

- Welke groeperingen worden toegelaten?

Een land accepteert migratie om diverse redenen, zoals economische belangen van het gastland, humanitaire redenen, problemen in verband met het bewaken van zijn eigen grenzen.

Migrantengroeperingen die worden toegelaten krijgen niet allemaal dezelfde status en mogelijkheden. Daardoor creëert de staat een sociaalpsychologische realiteit. Die realiteit creëert de staat door benamingen als gastarbeider, vreemdeling, vluchteling, toerist et cetera. Deze categorisering strekt zich verder uit tot de kinderen van migranten (tweede generatie). De legale status die de overheid verleent aan de eerste en de tweede generatie, heeft een grote impact op het acculturatieproces en de adaptatiestrategie waarvoor ze kiest.

Bourhis et al. (1997a) verdelen de strategieën die de staat ten opzichte van migranten kiest in vier categorieën: meervoudige ideologie, burgerlijke ideologie, assimilatie-ideo- 
logie en etnische ideologie. Nederland is een voorbeeld van een staat met meervoudige ideologie.

Deze ideologie is gebaseerd op het principe van de integratiestrategie. De meeste moderne politieke systemen kiezen voor deze strategie. Ze verwachten van migranten dat zij zich aanpassen en de politieke waarden van het gastland accepteren. Dit houdt onder andere in dat ze de principes van democratie moeten accepteren. Dit betreft alle normen die met civiele en criminele daden te maken hebben en door de staat opgesteld zijn, ook de mensenrechten die daarmee verbonden zijn. ledere burger dient de individuele rechten te respecteren die te maken hebben met privénormen van de burgers. De staat gaat zich niet verder bemoeien met de individuele normen en het privéleven van zijn burgers. Persoonlijke activiteiten die vrij zijn gesteld van de controle van de staat, zijn bijvoorbeeld huishoudelijke activiteiten, interpersoonlijke contacten, taal en culturele activiteiten, en religieuze ceremonies. Ook heeft iedereen de vrijheid om deel te kunnen nemen aan politieke, culturele en economische activiteiten en in de besteding van zijn vrije tijd. Deze privéactiviteiten vallen buiten de controle van de staat zolang ze niet in strijd zijn met de civiele en politieke wetten van het politieke systeem. Een bijzonder kenmerk van deze ideologie is dat alle culturele groeperingen hun culturele identiteit mogen behouden. Ze krijgen sociale en economische ondersteuning van de staat. Dit geldt voor alle mensen en groeperingen zolang ze belasting betalen. Deze ideologie accepteert de waarden van etnoculturele diversiteit.

Gijsberts \& Dagevos (2004) komen in hun studie tot de conclusie dat er in Nederland geen sprake is van aanpassing als gevolg van gevoerd integratiebeleid (structurele integratie). Aanpassing is uiteindelijk een individuele aangelegenheid en besluit. De verschillen in culturele integratie zijn beter te verklaren uit een goede of minder goede aansluiting op de waarden van de autochtone bevolking (sociaal-culturele integratie).

\subsection{Begeleiding: een kwestie van lange adem}

Vanaf het moment dat iemand in Nederland asiel aanvraagt, begint in wezen het begeleidingsproces. Begeleiding is een langdurig interactieproces dat plaatsvindt op basis van wisselwerking tussen de begeleider en de cliënt. In een ruime definitie van begeleiding wordt vooral de interactie tussen twee personen benadrukt, waarin het individu wordt geholpen verschillende opties te onderzoeken om te kunnen bepalen wat de kansen en de belemmeringen zijn van elke optie. Uiteindelijk is de persoon (cliënt) degene die tot een weloverwogen beslissing moet komen over de te zetten stappen. Bij deze cliëntgerichte begeleiding neemt de begeleider de rol van coach op zich en iedere beweging krijgt vorm vanuit het referentiekader van de hulpvrager (cliënt). De begeleider ondersteunt de cliënt, maar sluit zich steeds aan bij zijn/haar referentiekader.

In de praktijk is de begeleiding van vluchtelingen zeer ingewikkeld. Bij sommige gevallen is meer dan een 'directe interventie' nodig en neemt de begeleider de rol van adviseur 
op zich. Dit komt vooral door de volgende kenmerken van vluchtelingen: Vluchtelingen hebben hun eigen land gedwongen moeten verlaten. Een groot aantal van hen lijdt onder lichamelijke en psychische trauma's. Met hun zeer kwetsbare achtergrond komen vluchtelingen in een gastland terecht dat niet altijd vriendelijk en open tegenover hen staat; een situatie die bij velen nog meer verslechtering teweegbrengt. Het acculturatie- en integratieproces moet zo snel mogelijk plaatsvinden, terwijl de vluchteling nog niet vertrouwd is met de zeer individualistische westerse cultuur en gewoonten. Ook het verschil tussen de wereld zoals die is en het ideaalbeeld van de wereld zoals die zou moeten zijn en die de vluchteling verwacht, is groot. Al deze aspecten veroorzaken bij de groep vluchtelingen soms enorme conflicten tussen hun ideaalbeeld en de koude werkelijkheid. Het eigen referentiekader sluit niet meer aan bij de nieuwe werkelijkheid. Ook ontbreekt hier de sociale ondersteunende omgeving: de vluchteling kent de weg niet, hij heeft geen sociale ondersteunende netwerken en voelt zich voortdurend machteloos. Bala (1995) ziet het leven van vluchtelingen als een opeenhoping van veranderingen op individueel, gezinsen maatschappelijk niveau die de nodige stress teweegbrengt.

De bovenstaande aspecten rechtvaardigen de conclusie dat de begeleiding van de groep vluchtelingen speciale kenmerken heeft en bijzondere aandacht vraagt. Begeleiding is nodig bij het leren van de taal, deelnemen aan de arbeidsmarkt en het gebruikmaken van faciliteiten van de gezondheidszorg. Ook bij andere maatschappelijke activiteiten is de rol van begeleiding onmisbaar.

Omdat de middelen en de mogelijkheden die vluchtelingen tijdens hun verblijf in Nederland tot hun beschikking hebben bij iedere fase verschillen, loopt ook de subjectieve beleving van personen per fase anders. In de eerste fase en tijdens de asielprocedure, waarin nog niet is vastgesteld of de asielzoeker zich in Nederland mag vestigen, wordt er doelbewust een non-integratiebeleid gevoerd. Voor een zinvolle tijdsbesteding zijn er twee mogelijkheden: sociaal-culturele activiteiten en het beperkt leren van de Nederlandse taal. Van doelgerichte begeleiding naar scholing en de arbeidsmarkt is nog geen sprake. De reden hiervoor (zo beweert men) is dat het wekken van valse hoop onder asielzoekers vermeden moet worden.

Integratie is een proces van voorbereiding, hoop, bemiddeling, ondersteuning en aanpassing. Begeleiding maakt daarvan een wezenlijk onderdeel uit. ledere vluchteling is anders en heeft zijn/haar speciale verwachtingspatronen, behoeften en eigenschappen. Hoe een vluchteling het proces van begeleiding naar integratie ervaart, is een zeer subjectieve aangelegenheid die in een maatschappelijke context plaatsvindt. Begeleiding moet uiteindelijk tot een resultaat leiden en heeft een positieve uitkomst als de vluchteling zijn kansen op diverse maatschappelijke niveaus ziet vergroten. Deze perceptie van kansen breng ik onder in twee categorieën:

- Kansen met betrekking tot onderwijs en scholing, arbeidsmarkt, gezondheidszorg (materiële integratie).

- Kansen om zich hier thuis te voelen en hier thuis te raken, zich gelijkwaardig te voelen en zich gelukkig te voelen (immateriële integratie). 


\subsection{Trajectbegeleiding voor vluchtelingen}

Een belangrijke en onmisbare factor bij het integreren in het nieuwe land is het verrichten van betaald werk. Dit heeft niet alleen economische en financiële consequenties voor de nieuwkomer, maar draagt ook bij aan het gevoel van zelfwaardering, zelfvertrouwen en zich thuis voelen.

Om werkloosheid onder vluchtelingen te beperken en de toegang naar de arbeidsmarkt te verhogen, dient de overheid vroegtijdig te investeren in een passend traject. Dit kan immers de kans van vluchtelingen om sneller aan een geschikte baan te komen vergroten. Een geschikte baan kan gedefinieerd worden als een baan die goed aansluit bij het opleidingsniveau en de werkervaringen van vluchtelingen.

De werkloosheidsduur van vluchtelingen is hoger dan van andere werkzoekenden. In de praktijk blijkt dat de relatief hoge opleiding van sommige vluchtelingen niet aansluit bij de kwalificaties die de Nederlandse arbeidsmarkt vraagt. Voor langdurig werkloze hoger opgeleide vluchtelingen is een extra impuls wenselijk om hen te bereiken met behulp van een sluitende aanpak en hun een passend traject naar geschikt werk te bieden. Individuele trajectbegeleiding en coaching (maatwerk) vormt in de praktijk een succesfactor bij het verwerven van een arbeidsplaats.

Uit de gegevens van het Jaarrapport integratie (2004) blijkt dat vluchtelingen een slechte positie op de Nederlandse arbeidsmarkt hebben. Nederland telde in 2004 ongeveer 20.000 werkloze vluchtelingen. Het percentage werklozen verschilt per bevolkingsgroep. Zo zit slechts $17 \%$ van de vluchtelingen uit (voormalig) Joegoslavië zonder werk. Bij Iraniers is het percentage hoger (25\%). De economische crisis van de afgelopen jaren heeft duidelijk laten zien dat niet-westerse allochtonen nog altijd een kwetsbare positie innemen op de arbeidsmarkt. In 2010 was 12,6\% van de niet-westerse allochtonen werkloos tegenover $4,5 \%$ van de allochtonen. Aan de andere kant zien we dat niet-westerse allochtonen langzaam maar zeker steeds hoger opgeleid raken (CBS, 2010). Verder blijkt dat in alle leeftijdsgroepen het aandeel allochtonen in loondienst tussen 1999 en 2009 is gestegen. Onder niet-westerse allochtonen is het aandeel van de beroepsbevolking dat werkloos was iets toegenomen, van 12,6\% in 2010 naar 13,1\% in 2011. Deze toename is echter minder groot dan in de twee voorgaande jaren (CBS, 2011).

Trajectbegeleiding is een methodiek van inschakeling van werkzoekenden voor de arbeidsmarkt. Het succes van trajectbegeleiding is dan ook mede afhankelijk van hoe de cliënt (in dit geval een vluchteling) deze begeleiding ervaart en in het bijzonder of deze begeleiding kansen schept om de eigen positie te verbeteren.

Een standaardnorm bij het proces van begeleiding die altijd in ogenschouw genomen dient te worden, is 'vertrouwen' (Elchardus, 1998; Bermasco, 1999; Kramer \& Tyler, 1996; Van den Bos et al., 1999). Er zijn verschillende definities van vertrouwen. McAllister (1995) definieert 'vertrouwen' als de mate waarin een persoon bereid is te handelen op grond van de woorden, handelingen en beslissingen van een ander. 
Ook 'inspraak' blijkt bij het begeleidingsproces van essentieel belang te zijn (Korsgaard \& Roberson, 1995; Von Grumbkow \& Ramaekers, 2000a, 2000b). Inspraak verwijst naar de mogelijkheid om invloed uit te oefenen op beslissingen en/of op het beslissingsproces. Deze invloed heeft een instrumentele en ook een persoonlijke component. Instrumentele betrokkenheid en inspraak ontstaan als de cliënt de beslissing concreet kan beïnvloeden en als hij/zij optimaal wordt geïnformeerd. Dit aspect heeft dus te maken met informatie en invloed. De persoonlijke betrokkenheid en inspraak betreffen de gelegenheid om los van het uitoefenen van invloed aangehoord te worden (Von Grumbkow \& Ramaekers, 2000b).

Wil een trajectbegeleiding effectief zijn, dan moet ze merkbare en positieve gevolgen hebben voor de vluchteling. Meer zelfvertrouwen, meer beroepsvaardigheden en het gevoel dat er rekening wordt gehouden met zijn of haar persoonlijke omstandigheden, en het belangrijkste is uiteraard dat de vluchteling de indruk krijgt betere kansen te maken in diverse maatschappelijke sectoren (onder andere de arbeidsmarkt). Uit onderzoek van Schoormans \& Von Grumbkow (1988) en Von Grumbkow \& Ramaekers (2000a) blijkt dat procedures als juist worden beoordeeld als deze fair en transparant zijn en als ze rekening houden met de belangen van de cliënt. Uitkeringsgerechtigden die de procedures als rechtvaardig en juist ervaren, hebben positieve attitudes ten aanzien van de uitkeringsinstanties, zijn meer loyaal tegenover deze instanties en volgen eerder de regels die door deze instanties zijn opgesteld (Schoormans \& Syroit, 1989). Gedurende het integratieproces doorlopen vluchtelingen diverse procedures. In feite bestaat begeleiding vooral uit procedures, toewijzingen en beslissingen.

Een ander zeer belangrijk aspect van een goede begeleiding is rechtvaardigheid. Het individu dient het proces van begeleiding als rechtvaardig en eerlijk te ervaren. Leventhal (1980) omschrijft procedurele rechtvaardigheid als waargenomen eerlijkheid in een sociaal systeem. Hij gaat ervan uit dat ieder individu een cognitief plan heeft voor gebeurtenissen die leiden tot een verdeling of toewijzing van middelen of opbrengsten. Bij iedere soort begeleiding worden formele en informele beslissingen genomen. De wijze waarop beslissingen genomen worden en de procedure die tot de beslissingen leidt, beoordeelt de cliënt (vluchteling) in de mate waarin deze naar zijn/haar opvatting eerlijk en rechtvaardig zijn. Procedures die als eerlijk worden waargenomen, zullen ook als rechtvaardig worden beoordeeld.

Volgens Leventhal voldoet een eerlijke procedure aan een aantal eisen. Hij beschrijft de volgende regels die elk een bepaald rechtvaardigheidscriterium omvatten:

- De consistentieregel: deze regel is gebaseerd op gelijke kansen voor iedereen.

- De corrigeerbaarheidsregel: deze regel benadrukt dat de klachten van de cliënten zorgvuldig moeten worden afgehandeld.

- De representativiteitsregel: deze regel stelt dat men bij de besluitvorming rekening moet houden met de levenshouding van de cliënt (godsdienstnormen, waarden en dergelijke). 
- De accuraatheidsregel: informatie die de cliënt over de begeleiding ontvangt, dient volledig, zorgvuldig en juist te zijn.

- De ethiekregel: deze regel houdt in dat het systeem van begeleiding en de werkwijze van de begeleider door de cliënt als ethisch juist moeten worden opgevat.

In deze studie is de mate waarin de begeleiding als rechtvaardig gezien wordt, vastgesteld door aan de vluchtelingen vragen te stellen over bepaalde kenmerken van de begeleiding die ze ontvangen of ontvangen hebben.

De begeleidingsvragen die vluchtelingen in deze studie voorgelegd krijgen, zijn ontwikkeld op basis van het theoretische model van Leventhal (zoals hiervoor beschreven).

Het uitgangspunt van onderzoek 1 van deze studie is dat een begeleiding als effectief kan worden gezien als deze tot bepaalde resultaten leidt die in deze studie worden geformuleerd als: 'door de vluchteling waargenomen kansen'. Ik bouw hier voort op de studie van Ramaekers (2003).

\subsection{Verschillen in kansperceptie}

Ik ga ervan uit dat vluchtelingen in hun kansperceptie van elkaar verschillen. Dit verschil in kansperceptie kan naar mijn idee verklaard worden door de volgende aspecten:

- De fase van verblijf in Nederland: in fase 1 als asielzoeker en in fase 2 als een Nederlandse burger.

- De psychologische en individuele kenmerken van vluchtelingen.

- De wijze en de kenmerken van de begeleiding.

Deze drie aspecten zullen hierna worden toegelicht.

\section{A. De fase van verblijf in Nederland}

Naar mijn mening ligt het voor de hand te veronderstellen dat de verblijfsduur van de vluchteling van invloed is op zijn/haar perceptie van de kansen. Naarmate de vluchteling meer zekerheid heeft over de mogelijkheid om hier te blijven, nemen de kansen om te integreren en een eigen leven op te bouwen toe. Een vluchteling die zich nog in fase 1 bevindt, is meer onzeker over zijn toekomst in Nederland en zal minder gericht zijn op integratie dan een vluchteling die zich in fase 2 bevindt. In fase 1 is de aandacht van de vluchteling vooral gericht op het verkrijgen van een status, in fase 2 heeft de vluchteling een verblijfsvergunning tot zijn/haar beschikking en is daardoor meer gemotiveerd om te gaan integreren.

\section{B. De psychologische en individuele kenmerken van vluchtelingen}

Deze groep van factoren beschouw ik als interne factoren.

Als psychologische factoren worden in onderzoek 1 de mate van depressie, copingstijl en de mate van psychopathologie onder de loep genomen. Psychologische factoren spelen een belangrijke rol bij de ervaren begeleiding naar integratie. De etiologie van de psychopathologische klachten zoals depressie, angst en posttraumatische stressstoornis kan 
bij iedere fase van het verblijf anders zijn. Tijdens het verblijf in Nederland ervaart een grote groep van vluchtelingen ingrijpende gebeurtenissen. Dit zou een aanleiding kunnen zijn voor nog meer depressieve en/of psychopathologieklachten. Ook de traumatische ervaringen in het land van herkomst kunnen daardoor heftiger beleefd worden. Deze kunnen leiden tot verschillende belevingspatronen.

Coping wordt gedefinieerd als de manier waarop mensen met problematische situaties omgaan. Copingstijl is geen statisch patroon. Mensen hanteren bij verschillende situaties verschillende copingstijlen om problemen het hoofd te bieden. In dit onderzoek wordt nagegaan of deze gehanteerde strategieën zich per fase anders voordoen. Ook zou het effect dat deze factor heeft op de ervaren begeleiding naar integratie en de waargenomen kansen in Nederland, anders kunnen zijn.

Als individuele factoren worden de effecten van demografische factoren (geslacht, leeftijd en in het bezit zijn van een verblijfsvergunning) op de ervaren begeleiding onderzocht.

\section{De wijze en de kenmerken van de begeleiding}

Behalve individuele en psychologische factoren, spelen de begeleidingsfactoren als externe factoren een belangrijke rol bij de ervaren begeleiding. Deze factoren omvat ik in deze studie als begeleidingsvariabelen. De begeleiding naar integratie kent diverse vormen en heeft per fase een ander doel voor ogen. De wijze en de mate van begeleiding, de inspraak die de vluchteling ervaart over de genomen beslissingen en de mate waarin de vluchteling zich gerespecteerd voelt, worden als externe factoren in deze studie onder de loep genomen. Bij de wijze en kenmerken van de begeleiding gaat mijn aandacht uit naar de invloed van vijf groepen factoren. Deze factoren hebben betrekking op de wijze waarop vluchtelingen benaderd worden door de begeleider en/of de organisatie die de begeleiding voor haar rekening neemt.

De factoren die worden onderzocht zijn:

- De beleving van de juistheid en eerlijkheid van de procedure van begeleiding.

- De mate waarin de vluchteling via inspraak zich betrokken voelt bij de begeleidingsprocedure.

- De mate waarin de vluchteling vertrouwen heeft in de begeleidingsprocedure.

- De mate waarin de vluchteling tevreden is over zijn of haar begeleiding.

- De mate waarin de vluchteling zich met respect behandeld voelt. Met respect bedoel ik rekening houden met de culturele achtergrond en het gedragspatroon, en de wensen en de mogelijkheden van de vluchteling.

- De mate waarin de vluchteling zich (niet) gediscrimineerd voelt.

De eerste vier aspecten staan in het kwantitatieve deel van deze studie centraal (onderzoek 1). In het kwalitatieve deel (onderzoek 2) krijgen de culturele achtergrond en persoonlijke wensen en beleving van de respondenten aandacht (zie Leventhal, 1980).

Deze studie gaat ervan uit dat deze factoren invloed uitoefenen op de perceptie van kansen om in Nederland succesvol te kunnen integreren. 


\subsection{Vraagstellingen van kwantitatieve onderzoeken}

Steunend op de literatuurstudie heb ik de volgende vraagstellingen voor twee kwantitatieve onderzoeken geformuleerd. Deze vraagstellingen zijn al eerder vermeld op pagina's 12 en 13.

De centrale vragen van onderzoek 1 heb ik als volgt geformuleerd:

- In hoeverre en hoe hebben de vorm en de inhoud van de begeleiding invloed op de relatie tussen ervaren begeleiding en de waargenomen kans van de vluchteling om zijn/haar positie in de Nederlandse samenleving te verbeteren?

- In hoeverre en hoe zijn de fase van integratie waarin de vluchteling zich bevindt, individuele en psychologische factoren als depressie, copingstijl en de mate van algemene psychopathologie van invloed op de relatie tussen ervaren begeleiding en de waargenomen kansen van de vluchteling om zijn/haar positie in de Nederlandse samenleving te verbeteren?

De vraagstellingen van onderzoek 3 heb ik als volgt geformuleerd:

- In welke mate hebben de respondenten last van psychopathologische klachten en met name van angst- en depressieve klachten?

- Hebben de respondenten gezien hun achtergrond veel last van posttraumatische stressklachten?

- Is er een verschil tussen de twee groepen van de respondenten (vluchtelingen met een permanente verblijfsvergunning en respondenten met een pardonregeling) met betrekking tot psychopathologie, PTSS-klachten en de copingstijlen? 


\section{Hoofdstuk 3}

\section{Cultuurverschillen en integratie van Iraanse vluchtelingen}

In een multiculturele samenleving is communicatie tussen diverse groepen en individuen een noodzaak. Mensen met diverse opvattingen, waarden en normen, en gewoontes wonen naast elkaar en leven met elkaar. Dit kan soms tot conflicten en misverstanden leiden. In de afgelopen periode is er veel discussie geweest over de kwestie 'aanpassen aan de normen en waarden'. De meningen over de manier waarop de grenzen en de mate van inspanning tot integratie kunnen leiden, lopen uiteen. Bovendien blijken er ook verschillen te bestaan tussen allochtone en autochtone Nederlanders over de mate van succes van integratie van nieuwkomers in de Nederlandse samenleving. Bestaat er eigenlijk een verband tussen de culturele achtergrond en de mate van integratie? Zou het cultuurverschil tussen het gastland en het migratieland de voortgang van het integratieproces kunnen belemmeren? Welke aspecten van twee culturen hebben een belemmerend of juist een bevorderend effect op het proces van integratie? Hoe zit het met de integratie van Iraanse vluchtelingen in Nederland?

Deze onderwerpen komen in dit hoofdstuk aan de orde. Ik bespreek eerst de begrippen cultuur en cultuurverschil. Individualisme en collectivisme als twee belangrijke aspecten van cultuurverschil passeren de revue. Het effect van cultuurverschil op de communicatie tussen allochtonen en autochtone Nederlanders komt globaal aan bod. De Nederlandse samenleving als een dominante cultuur en de standpunten van autochtone Nederlanders ten opzichte van allochtonen komen in beeld. Dit hoofdstuk is informatief bedoeld en wordt afgesloten met een korte schets van Iran en de integratie van Iraanse vluchtelingen in Nederland.

\subsection{Cultuur als begrip}

Van het woord cultuur zijn diverse definities in omloop.

Cultuur is beschreven als het geheel van levenswijzen die een groep ontwikkeld heeft over een langere historische periode. Tot de cultuur behoren de normen en waarden, geloofsopvattingen, taal, symbolen, denkpatronen en communicatiestijlen. Cultuur is een belangrijk middel dat groepen ontwikkelen om in een bepaalde fysieke en sociale omgeving te kunnen overleven. Cultuur wordt in vele gevallen gezien als een onafhankelijke factor; een factor die gedrag en denken van de leden van een bepaalde cultuur beïnvloedt. Vooral de crossculturele psychologie houdt zich hiermee bezig.

Cultuur wordt gedefinieerd als een 'serie van subjectieve en objectieve elementen' die in de geschiedenis van de mensheid een overlevingswaarde hebben gehad. Dit had een positief resultaat op het ecologische voortbestaan van de mensheid. De objectieve en 
subjectieve elementen werden later gemeenschappelijk gebruikt door groepen mensen die dezelfde taal spraken en in dezelfde plaats woonden. Cultuur is volgens deze definitie alles wat in het verleden goed gewerkt heeft en nu verenigd is in de cognitie van de mensen die met elkaar communiceren. Volgens deze definitie vallen onder cultuur alle gereedschappen, standaardprocedures, categorieën en de manier van leven die mensen door middel van taal aan elkaar overdragen (Triandis, 1994). Volgens Mezzich et al. (1993) is het begrip cultuur te beschrijven als: 'het geheel aan betekenissen, waarden en gedragingen die aangeleerd en overgedragen worden in een gemeenschap en in zijn sociale groepen'. Als wij over een cultuur van een bepaald land of een bepaalde regio spreken, dan spreken wij over de cultuur van de dominante groep ter plekke.

De wijze waarop het begrip cultuur gedefinieerd wordt, kan men dus op een continuum van statisch tot dynamisch plaatsen (Boomstra \& Kramer, 1997). In een statische definitie wordt het begrip 'cultuur' vooral geassocieerd met etniciteit of etnische achtergrond. Het gaat dan om waarden, normen en levensstijlen die in verband worden gebracht met het land van herkomst. In deze definitie stereotypeert men het gedrag van mensen uit andere culturen. In een dynamische definitie wordt het begrip vooral in verband gebracht met interculturele communicatie tussen verschillende groepen. leder individu is volgens de dynamische definitie een unieke combinatie van verschillende culturele oriëntaties en invloeden: iedere persoon hoort bij verschillende culturele groepen. De structuurtheorie neemt een tussenpositie onder de twee definities in. Deze theorie benadrukt vooral de relatie tussen sociaal systeem, cultuur en het individu. De emancipatorische doelstelling neemt een belangrijke plaats in bij deze theorie: het verbeteren van de positie van allochtone groepen wordt namelijk als doelstelling vastgesteld. Hofstede \& Hofstede (2005a) zien cultuur als mentale programmering. Ze vergelijken deze met de wijze waarop computers worden geprogrammeerd. Volgens de auteurs handelen mensen niet alleen maar op basis van hun culturen, integendeel: mensen beschikken over een fundamenteel vermogen om daarvan af te wijken en te reageren op manieren die nieuw, creatief, destructief of onverwacht zijn. Hier gaat het om een dynamische betekenis van cultuur. Shadid (2007) beschrijft het woord cultuur als 'een samenhangend geheel van symbolen en betekenissen, dat de mens oriënteert op de werkelijkheid, waarin hij leeft'.

Deze studie sluit aan bij de hiervoor genoemde definitie van zowel de dynamische als de structuurtheorie over het begrip cultuur.

\subsection{Cultuurverschil}

Ondanks het feit dat de meeste wereldculturen grote overeenkomsten vertonen op het gebied van bepaalde basiswaarden, zoals het recht van anderen op leven, huwelijk, vriendschap en verwantschap, is er toch sprake van grote diversiteit tussen verschillende groepen.

leder land kent meerdere culturen die als subculturen kunnen worden beschouwd. Hoewel de cultuur van een land geen scherpe grenzen heeft, is een algemeen beeld dat 
het woord cultuur oproept meestal de cultuur van de dominante groep.

Over het algemeen maken mensen deel uit van vele sociale eenheden en daarmee verbonden culturen. Mensen maken dus deel uit van een groot aantal aan elkaar gebonden en overlappende culturele sets (Vermeulen, 2002). Shadid (2007) ziet de subculturen als het resultaat van de creatieve pogingen van bepaalde groepen om problemen, spanningen en behoeften die zij in een gemeenschappelijke situatie ervaren, op te lossen.

Door de interactie met andere culturen, de veranderende behoeften van individuen en de eisen die een bepaalde tijd stelt, zijn de verschillende culturen voortdurend in beweging. Daarnaast kent iedere cultuur ook een stabiele kant. Deze functioneert als een systeem met zijn eigen karakteristiek. In die zin brengt een cultuur bepaalde soorten mensen, hun interacties en hun eigen instituten voort. In dit geval spreekt men bijvoorbeeld van de Nederlandse cultuur of de Iraanse cultuur. Men schrijft dan bepaalde eigenschappen toe aan bepaalde groeperingen.

Het beoordelingsproces is niet altijd even objectief. Cultuurverschil is dus geen relatief maar een relationeel fenomeen dat vooral over interacties gaat (De Vries, 2002).

\subsubsection{Individualisme/Collectivisme}

Hofstede $(1980,1983,1997)$ en Hofstede \& Bond (1984) beschreven vier culturele dimensies in een multiculturele samenleving: machtsverschil, onzekerheid, individualisme/collectivisme en mannelijkheid/vrouwelijkheid. Later voegde Hofstede daaraan een vijfde dimensie toe. Hij zette de oosterse volharding tegenover de westerse drang naar waarheid en onmiddellijk resultaat. Deze dimensies reflecteren een 'patroon van denken, voelen en acties' en zij spelen daarom een zeer belangrijke rol bij het proces van interculturele interacties. Eén van de bovengenoemde dimensies die voor deze studie van belang is, bevat twee tegenovergestelde elementen: individualisme/collectivisme.

Een individualistische cultuur zoals we die in de westerse landen tegenkomen, kent de volgende karakteristieken:

In de eerste plaats zijn mensen met individualistische culturen onafhankelijk van de groep. 'Zelf' is een onafhankelijk zelf en staat in verband met aspecten als zelfversterkend, zelfassertief, hoog zelfvertrouwen, welbevinden en optimisme. In collectivistische culturen zoals in Azië en Latijns-Amerika, heeft 'zelf' een afhankelijk karakter. In deze (traditionele) culturen is het 'zelf' een concept dat tot één of meerdere groepen behoort. Een afhankelijk zelf heeft een primair verband met aspecten als passen bij en een goed lid zijn van de groep en wordt vaak in verband gebracht met aspecten als bescheidenheid, ingetogenheid en een matig niveau van welbevinden.

In de tweede plaats krijgen in individualistische culturen persoonlijke doelen een prioriteit boven de groepsdoelen (Triandis, 1990; Yamaguchi, 1994; Triandis, 2001).

In de derde plaats worden in individualistische culturen gedragingen van mensen bepaald door attitudes. Normen hebben een geringe invloed op het gedrag van mensen (Bontempo \& Rivero, 1992; Dawson et al., 1996; Kashima et al., 1992), in tegenstelling tot collectivistische culturen waar normen belangrijker zijn dan attitudes. 
In de vierde plaats neemt in individualistische culturen het 'eigenbelang' een belangrijke plaats in (Triandis, 1995). Mensen maken een afweging tussen de voor- en nadelen die een bepaalde relatie voor hen heeft. Ze blijven meestal in een relatie als deze voor hen meer voordelen heeft. In collectivistische culturen gaat het gemeenschappelijke belang boven het belang van het individu. Ze blijven in relaties ongeacht het feit of ze hiervan profijt hebben. Triandis \& Gelfand (1998) onderscheiden twee variaties tussen de twee culturen, te weten horizontale en verticale variaties. Horizontaal individualisme benadrukt de uniekheid van het individu, terwijl in verticaal individualisme de ene persoon beter is dan de andere. Verticaal individualisme bemoedigt de concurrentie tussen de leden van de samenleving.

Horizontaal collectivisme benadrukt de eenheid van 'zelf' en de groep. In verticaal collectivisme wordt de gehoorzaamheid aan de groep sterk benadrukt en aangemoedigd. Zich opofferen voor de gemeenschappelijke idealen en/of belangen van de groep is een opmerkelijk aspect van verticaal collectivisme.

Nederland is een voorbeeld van een horizontaal individualistische cultuur. De cultuur van Iran is een combinatie van oude en moderne elementen. Deze elementen zijn de klassieke Iraanse cultuur van het Perzische Rijk uit de oudheid, de islamitische cultuur en de moderne westerse cultuur (Hessels, 2002). Naar mijn mening heeft deze combinatie van de Iraanse cultuur een semi-individualistische/semicollectivistische cultuur gemaakt. Dit betekent dat de Iraanse cultuur aspecten van zowel individualistische als collectivistische aard heeft.

\subsubsection{Ik/Wij-cultuur}

Men gebruikt meestal twee soorten definities van het woord 'wij'. De eerste definitie heeft te maken met de groepsidentiteit en wordt geassocieerd met begrippen als familie, natie, kerk en professionele organisaties.

Een andere definitie omvat een bredere inhoud en wordt meer in verband gebracht met attributieve identiteit en met abstracte begrippen, zoals: 'wij die racisme afkeuren' of 'wij die rechtvaardigheid willen'. De eerste definitie van 'wij' is een collectivistische begripsomschrijving: mensen die een groepsidentiteit hebben, onderwaarderen de successen van andere groepen, terwijl degenen die een attributieve identiteit gebruiken dit niet doen. Volgens Markus \& Kitayama (1991) behoren mensen tot een collectivistische cultuur wanneer ze weinig verschil zien tussen 'ik' en 'wij'. Mensen die tussen hun eigen groep en de andere groepen grote verschillen constateren, hebben meestal ook de neiging om meer te stereotyperen en meer nationalistische begrippen in hun interpretatie en hun oordelen te gebruiken.

Het verschil tussen 'wij en ik'-culturen (collectivistisch versus individualistisch) zou kunnen leiden tot een verschil in centrale culturele waarden. In diverse studies is benadrukt dat deze verschillen tot conflicten tussen diverse culturen en/of subculturen kunnen leiden (Oetzel \& Ting-Toomey, 2006; Orbe \& Everett, 2006). Dit heeft namelijk effect op alle interpersoonlijke en groepsverhoudingen binnen een samenleving. 
Bij contacten tussen verschillende culturen zijn vooral de overeenkomsten tussen groepen belangrijk. De meerderheid van de bevolking van een land waardeert groeperingen die op haar lijkt. Culturele verschillen creëren het gevoel van ongelijkheid. Ongelijkheid in combinatie met weinig contact tussen groepen zou tot conflicten kunnen leiden. Als de culturele afstand niet te groot is, neemt het gevoel van gelijkheid toe. Ook neemt het gevoel van gelijkheid toe indien de ene groep meer informatie ter beschikking heeft over de andere groep. Hoe meer de ene groep kennisneemt van de andere groep, hoe meer deze groep erin slaagt om het gedrag van de andere groep beter te begrijpen.

De perceptie van gelijkenis neemt toe als de twee groepen meer gemeenschappelijke doelen, status, belangen en interesses hebben (Byrne, 1971; Brewer \& Campbell, 1976). Feitelijke, juiste en betrouwbare instrumenten die het gedrag en de reacties van de andere groep meer voorspelbaar maken, leiden tot het gevoel dat de eigen groep meer controle heeft op de onderlinge interacties. Het resultaat is dat de ene groep zich minder bedreigd voelt door de andere groep.

In feite categoriseren we allemaal de wereld. Mensen benadrukken de verschillen tussen de leden/elementen van verschillende groepen en accentueren de overeenkomsten tussen de leden van de groepen door deze onder dezelfde categorie te plaatsen. Dit proces is rationeel en is gebaseerd op het principe van assimilatie-contrast van de Gestaltpsychologie.

Deze informatie over cultuurverschillen is voor deze studie van belang omdat verschillen en overeenkomsten tussen de Nederlandse en Iraanse culturen effect kunnen hebben op de manier waarop Iraanse vluchtelingen de begeleiding naar integratie ervaren. In deze studie heb ik in de begeleidingsvragenlijst niet de aspecten van individualistische of collectivistische culturen meegenomen. Ik heb wel in onderzoek 1 en vooral in onderzoek 2 gerichte aandacht besteed aan culturele verschillen tussen Iraanse en Nederlandse culturen. Ik heb stilgestaan bij aspecten als zakelijkheid en afstandelijkheid van het begeleidingsproces.

\subsection{Acculturatie en acculturatiestrategieën}

Migratie is een gegeven van het moderne leven. Wereldwijde bewegingen brengen verschillende groepen mensen met diverse culturele achtergronden in contact met elkaar. Het contact tussen migranten en bevolkingsgroepen is meestal onzichtbaar. De verandering in het originele cultuurpatroon is het resultaat van interpersoonlijke interacties of interacties tussen groepen. De verandering die optreedt, wordt in de literatuur met het woord acculturatie betiteld (Redfield et al., 1936). In diverse studies zijn vragen gesteld over het gedrag van de nieuwkomers met betrekking tot diverse aspecten zoals de taal, de mate van sociale contacten met allochtonen en de culturele gewoonten (Roccas et al., 2000; Birman \& Trickett, 2001; Shen \& Takeuchi, 2001; Ataca \& Berry, 2002; Berry, 2005; Stevens et al., 2005; Domínguez \& Maya-Jariego, 2008). In andere studies richt men zich op de 
psychologische aspecten van acculturatie zoals emotionele binding, identiteitsproblematiek, persoonlijke waarden en psychisch welbevinden (Berry, 2001; Meredith et al., 2000; Arcia et al., 2001; Tropp et al., 1999; Zheng et al., 2004; Langley \& Jones, 2005; Matheson et al., 2008; Choi et al., 2009). Haan et al. (2007) onderzochten de invloed van acculturatie en traumatische stress onder Bosnische vluchtelingen in Nederland. Het behoud van Bosnische culturele tradities en gewoonten bleek samen te hangen met een betere ervaren gezondheid. Dat gold ook voor het beheersen van praktische vaardigheden om in de Nederlandse samenleving te kunnen functioneren, het hebben van een baan en een langere verblijfsduur.

Acculturatie doet zich voor wanneer groepen en individuen met diverse culturele achtergronden voor een lange periode met elkaar contact houden (Berry, 1992). Acculturatie wordt gezien als een proces waarlangs het individu een proces van adaptatie doorloopt. Het acculturatieproces verwijst naar een niveau van adaptatie van de non-dominante cultuur aan de dominante cultuur. Hoe uitgebreider het acculturatieproces, hoe meer aanpassing aan de gewoontes, de taal, identiteit, attitude en het gedrag van de dominante cultuur (Domino \& Acosta, 1987; Garza \& Gallegos, 1985; Negy \& Woods, 1992a).

Het contact tussen de dominante en niet-dominante groepen loopt meestal harmonieus en er zijn overeenkomsten over wat ze als verandering verwachten. Toch doen zich ook in sommige gevallen spanningen en conflicten voor (Zagefka \& Brown, 2002). Een conflict wijst erop dat de twee groepen verschil van mening hebben ten opzichte van de richting en de mate van de verwachte verandering. Volgens Berry $(1992,1997,2001)$ is er sprake van adaptatie als er een poging wordt ondernomen om deze spanning en conflicten te vermijden. Berry beschreef adaptatie als een serie van strategieën die tijdens het acculturatieproces gehanteerd worden om spanningen te vermijden.

Volgens de acculturatietheorie van Berry zijn er twee vragen waarmee migranten tijdens de adaptatieperiode geconfronteerd worden:

- Wenst de migrant zijn/haar eigen culturele identiteit te behouden?

- Wenst de migrant positieve contacten te onderhouden met de leden van de dominante samenleving? (Berry, 1980, 1992; Berry et al., 1992; Poortinga et al., 1993; Berry, 2005)

Afhankelijk van het antwoord op deze twee vragen zijn er vier verschillende vormen van acculturatie mogelijk. Deze vier bekende strategieën zijn: integratie, assimilatie, separatie en marginalisatie. 
Vormen van acculturatie (Berry, 1992)

\begin{tabular}{|c|c|c|c|}
\hline & & \multicolumn{2}{|c|}{$\begin{array}{l}\text { Acht men het van belang om de eigen } \\
\text { culturele identiteit te behouden? }\end{array}$} \\
\hline & & $\mathrm{Ja}$ & Nee \\
\hline $\begin{array}{l}\text { Acht men het van belang } \\
\text { om met andere culturele }\end{array}$ & Ja & Integratie & Assimilatie \\
\hline groepen om te gaan? & Nee & Separatie & Marginalisatie \\
\hline
\end{tabular}

Als de migrant zijn/haar culturele identiteit graag wil behouden en tegelijk geïnteresseerd is in contact met een dominante groep, is er sprake van integratie. Veel Italianen in Nederland hebben gekozen voor deze vorm van adaptatiestrategie (Lindo, 1994).

Bij assimilatie kiest de nieuwkomer voor contact met de leden van de dominante groep en heeft weinig belangstelling voor zijn/haar eigen culturele achtergrond. Terwijl bij de integratiestrategie de migrant primair kiest voor het behouden van de eigen culturele identiteit, is bij assimilatie sprake van 'streven naar de nieuwe culturele identiteit'. Voorbeelden van groepen die voor assimilatie hebben gekozen zijn migranten uit Indonesië (een voormalige kolonie van Nederland) (Ellemers \& Vaillant, 1985) en migranten van een aantal Oost-Europese landen (Brassé \& Van Schelven, 1980).

We praten over separatie als de migrant weigert contact te houden met de dominante groep, maar zijn eigen originele identiteit wil behouden. Zigeuners zijn een voorbeeld van deze vorm van adaptatiestrategie (Penninx, 1988). Ten slotte is er sprake van marginalisatie als de migrant geen belangstelling heeft noch voor zijn/haar culturele identiteit, noch voor de cultuur van de dominante groep. Volgens Buijs \& Nelissen (1994) en Roelandt \& Veenman (1991) is een groep van de tweede generatie van Marokkanen in Nederland een voorbeeld van een migrantengroepering die gekozen heeft voor marginalisatie. Deze groep Marokkanen leeft aan de grenzen van de Nederlandse samenleving.

Het acculturatiemodel van Berry $(1992,1997)$ is een tweedimensioneel model waarin ervan uitgegaan wordt dat mensen zowel gericht kunnen zijn op hun oorspronkelijke cultuur als op de huidige en nieuwe cultuur (Eyou et al., 2000; Jasinskaja-Lahti \& Liebkind, 2000; Nguyen \& von Eye, 2002; Berry, 2001; Nguyen, 2006).

Berry (2001) zet zich af tegen het streven naar het behoud van een cultuur louter om de cultuur zelf, afgezien van de waarde en functies die ze heeft voor individuen. 


\subsection{Integratie als de meest favoriete adaptatiestrategie}

Integratie werd door diverse onderzoekers beschouwd als de meest effectieve strategie met de beste acculturatieresultaten (Berry, 1997; Berry et al., 1987). Bovendien bleek uit verschillende studies dat integratie de meest favoriete adaptatiestrategie onder migranten is (Berry, 1997; Van de Vijver et al., 1999). Integratie leidt tot het beste resultaat omdat migranten daardoor een gemeenschappelijke culturele identiteit met de dominante groep kunnen delen en daarnaast kunnen ze zichzelf op een positieve manier onderscheiden van de dominante groep (Dovidio et al., 1998; Gaertner \& Dovidio, 2000). In tegenstelling tot integratie wordt marginalisatie beschouwd als een zeer negatieve oriëntatie ten opzichte van beide culturen, die leidt tot meer stress bij migranten (Berry et al., 1992).

Uit literatuurstudie blijkt dat de meerderheid van migranten in Nederland voor integratie kiest. Uit de studie van Van Oudenhoven et al. (1998) onder Turken en Marokkanen blijkt dat deze twee groepen een voorkeur hebben voor integratie. Lang niet alle migrantengroeperingen kiezen in de praktijk voor integratie. Migranten die gezien hun culturele identiteit meer op Nederlanders lijken, zoals de voormalige Nederlands Indiërs, hebben voor een groot deel hun voorkeur aangegeven voor assimilatie (Ellemers \& Vaillant, 1985). Ook Surinamers (Van Oudenhoven et al., 1996) hebben voor assimilatie gekozen. Volgens de auteurs zijn er twee oorzaken voor:

- Surinamers zijn in sterke mate en voor een lange periode geconfronteerd met de Nederlandse cultuur.

- Assimilatiestrategie zorgt voor meer acceptatie van de Nederlanders.

Omdat integratie een tweezijdig proces is, wordt het acculturatieproces ook beïnvloed door de houding die de dominante groep inneemt tegenover migranten. Daarnaast heeft het beleid van de regering en de culturele afstand tussen dominante en non-dominante groepen grote effecten op het verloop van het acculturatieproces.

Uit onderzoek van Vedder \& Van de Vijver (2003) onder allochtone jongeren blijkt dat de waargenomen discriminatie een forse negatieve invloed heeft op zowel socioculturele als psychologische aanpassingen.

\subsection{Multiculturele/multi-etnische samenlevingen}

Nederland is net als vele andere Europese landen een multiculturele samenleving. Dit verschijnsel impliceert een grote verscheidenheid aan culturele achtergronden in de Nederlandse samenleving (Van de Vijver, 2001). Het globaliseringbeleid in de westerse landen leidt tot tijdelijke en permanente migratie en intensieve interculturele contacten. De nieuwe ontwikkelingen leiden tot nieuwe en waarschijnlijk permanente culturele veranderingen van de westerse samenlevingen. Als gevolg hiervan bestaan er binnen de westerse landen verschillende culturele groepen naast elkaar. 
Tegenwoordig zijn er weinig gebieden in de samenleving die niet op een of andere manier te maken hebben met mensen uit andere etnische groepen. Minderheidsgroeperingen onderscheiden zich meestal van de meerderheid door hun ras, geboorteland, religie en andere culturele eigenschappen. Etnische minderheden vormen een collectiviteit binnen de samenleving, waarvan de leden een feitelijke dan wel vermeende gemeenschappelijke afstemming hebben.

Alle etnische groepen hebben een cultuur die voortdurend in ontwikkeling is. Etnische groepen zijn in feite culturele groepen. Mensen die tot lid van een etnische groep gerekend worden, hebben bepaalde culturele kenmerken van hun gemeenschap. Deze kenmerken worden van generatie tot generatie overgedragen en behoren tot de oorspronkelijke etnische groep. In een land dat zich niet als immigratieland beschouwt, zijn nieuwkomers geen immigranten maar tijdelijk verblijvende onderdelen van een andere politieke gemeenschap. Nieuwkomers zijn vreemdelingen en de overheidsbemoeienis beperkt zich tot justitiële aspecten. Landen die zich wel expliciet als een immigratieland zien, voeren bewust een selectief immigratiebeleid en zien de nieuwkomers in principe als nieuwe burgers. Eenmaal toegelaten, krijgen ze gemakkelijk toegang tot het staatsburgerschap. Deze landen zijn gericht op voortdurende immigratie en het zo spoedig mogelijk benutten van het potentieel van nieuwe immigranten.

De meeste Noord-Europese landen, waaronder Nederland, bevinden zich tussen deze twee groepen: zij zijn immigratielanden 'tegen wil en dank'.

\subsection{De houding van de dominante groep}

In de meeste traditionele studies is eenzijdig een groot accent gelegd op de rol van migranten tijdens het acculturatieproces. De rol die het gastland daarbij speelt, wordt meestal onderschat. In sommige studies richten de onderzoekers hun aandacht wel op de houding van autochtone groepen tegenover allochtonen (Bourhis et al., 1997a; Van Oudenhoven et al., 1998).

Volgens Bourhis en zijn collega's kiest het gastland net als de migrant voor één van de vier acculturatiestrategieën. Deze strategieën noemen ze integratie, assimilatie, afscheiden (vergelijkbaar met separatie) en uitsluiting (vergelijkbaar met marginalisatie).

Het gastland heeft bepaalde ideeën en voorkeuren over hoe ze met migranten om wil gaan en hoe migranten zich in het gastland moeten gedragen. Dit gedachtegoed wordt door Bourhis en zijn collega's verder uitgewerkt in het Interactieve Acculturatie Model (IAM).

Volgens dit model neemt het begrip 'fit' (vergelijkbaar met het woord zich aanpassen) een belangrijke plaats in bij het definiëren van de houding van het gastland en vervolgens bij het proces van acculturatie. Het model onderscheidt drie soorten van fit: overeenstemming, problematiek en conflict.

Een overeenstemmingsfit komt tot stand als beide groepen voor een integratiestra- 
tegie kiezen. Bij problematiekfit kiest de migrant voor integratie terwijl het gastland voor marginalisatie kiest. In alle gevallen waarin zowel het gastland als de migrant het contact weigert, is er sprake van conflictfit, omdat beide groepen weinig kennis hebben van elkaars behoeften en eigenschappen. Het beste resultaat is te verkrijgen door overeenstemmingsfit. Dit leidt tot lage acculturatiestress, lage intergroepspanning, positieve interetnische attitude en weinig discriminatie. Problematische fit leidt tot weinig gunstige resultaten en conflictfit brengt het slechtste resultaat teweeg.

De psychologische interacties tussen het individu en de realiteit van zijn omgeving worden door zijn subjectieve perceptie van de realiteit gemedieerd. Het meten van de mate van fit is daarom belangrijk. Er is sprake van een functionele fit als er overeenstemming bestaat tussen de strategievoorkeur van de persoon aan de ene kant en zijn waarneming van de voorkeur van de dominante groep aan de andere kant.

Tabel 3.1 Het Interactieve Acculturatie Model (IAM)

\begin{tabular}{|l|l|l|l|l|}
\hline Attitude gastland & \multicolumn{4}{l|}{ Attitude migrant } \\
\hline & Integratie & Assimilatie & Separatie & Marginalisatie \\
\hline Integratie & O & P & C & C \\
\hline Assimilatie & P & O & C & C \\
\hline Afscheiding (separatie) & C & O & C & C \\
\hline $\begin{array}{l}\text { Uitsluiting } \\
\text { (marginalisatie) }\end{array}$ & C & C & C & C \\
\hline
\end{tabular}

$C=$ conflict,$O=$ overeenstemming,$P=$ problematiek

Hoe groter het attitudeverschil tussen de twee partijen, hoe slechter de mate van fit. Conflictfit kan tot stand komen als de twee groepen dezelfde disfunctionele attitudes ten opzichte van elkaar hebben (beide marginalisatie of separatie).

De mate van tolerantie is per dominante groep verschillend. Murphy (1965) beschrijft de mate van steun die een dominante groep verleent aan de immigranten, en het niveau van acceptatie die ze vertoont ten opzichte van het onderhouden van de culturele identiteit van de acculturatiegroep. Niet alle etnische groepen worden in gelijke mate geaccepteerd door de dominante groep. De ongelijke attitude van de dominante groep wordt vooral beïnvloed door het niveau van discriminatie en de vooroordelen die bestaan over 
bepaalde etnische groeperingen. De genoemde factoren beïnvloeden niet alleen het verloop van het acculturatieproces, maar hebben ook een groot effect op het gevoel van welbevinden en de gezondheid van etnische groepen.

Van Oudenhoven et al. (1998) zien assimilatie en integratie als adequate acculturatiestrategieën, waarbij de voorkeur van migranten vooral zal uitgaan naar integratie en die van de dominante groep naar assimilatie. Berry (1976) beschrijft drie soorten van aanpassingsstrategieën die tot verschillende adaptatieresultaten leiden: aanpassing, reactie en isolement.

Bij aanpassing treedt een wijziging in het organisme op die tot weinig verandering en tot hoge mate van fit leidt. In reactie treedt ook verandering op, maar niet in de vorm van positieve culturele verandering en gedragsacceptatie. Isolement leidt tot een richting van verandering die weinig druk voor de omgeving en het organisme teweegbrengt. In dit geval wordt het organisme door de omgeving verstoten.

\subsection{De Nederlandse samenleving als een dominante groep}

De onderzoeken van Hagendoorn \& Hraba (1989), Hagendoorn et al. (2003) en Scheepers et al. (2004) over de houding van Nederlanders ten opzichte van minderheidsgroeperingen brachten een paar opmerkelijke feiten aan het licht. Hun studies lieten zien dat etnocentrisme en discriminatie in Nederland in de afgelopen jaren zijn toegenomen.

In de jaren tachtig won een kleine rechtse partij (Centrum Partij) een relatief groot aantal stemmen. De campagne van de partij was duidelijk gericht op pro-Nederlanders en anti-buitenlanders. Dit nieuwe politieke verschijnsel bracht veel discussie over het onderwerp'racisme' teweeg. Het onderzoek van Hagendoorn en Jansen in 1983 en 1986 liet zien dat $42 \%$ van de middelbare scholieren zeer conservatieve ideeën had over allochtonen. $32 \%$ had geloof in een autoritair systeem, $27 \%$ was etnocentrisch, $8 \%$ had extreem rechtse ideeën en 1,6\% wilde een racistische politieke partij. De Jong en Van der Toorn-Den Hartog rapporteerden in 1984 nog grotere percentages van etnocentrisme en vooroordelen. Een kleine fractie van de respondenten had extreem rechtse overtuigingen.

Uit het grootschalige onderzoek van Van Oudenhoven (2000) blijkt dat autochtone Nederlanders een voorkeur hebben voor de minderheidsgroepen die op hen lijken. Migranten proberen hun eigen positie in de samenleving te bepalen. De realisering van bepaalde adaptatievormen kan belemmerd of gestimuleerd worden door de omgeving en voornamelijk door de attitude van de meerderheidsgroepen. In het onderzoek van Van Oudenhoven wordt de houding van de Nederlandse samenleving ten opzichte van een aantal etnische minderheidsgroepen besproken. Integratie en assimilatie zijn twee strategieën die zowel door migranten als door de Nederlanders als favoriete strategieën zijn benoemd. Deze twee strategieën geven migranten de mogelijkheid om volledig in de samenleving te kunnen participeren. Uit onderzoek onder Turkse en Marokkaanse groepen blijkt dat beide groepen een voorkeur hebben voor integratie, terwijl de Nederlandse 
respondenten van mening zijn dat zij zich vooral separeren. Dit verschil van mening en perceptie zou veroorzaakt kunnen zijn door diverse factoren:

- Een geringe mate van contact tussen de Nederlandse bevolking en deze twee groepen migranten.

- Vooroordelen.

- Het gebrek aan feitelijke kennis van de Nederlanders over de twee migratiegroepen.

- De maatschappelijke positie van de Nederlanders ten opzichte van deze twee groepen.

Uit dit onderzoek bleek verder dat de migranten positief worden gewaardeerd als ze zich maar net zo gedragen als Nederlanders. Wat de mate van tolerantie van Nederlanders betreft, blijkt dat deze een pragmatische basis heeft. Wanneer het economisch gezien goed gaat, zijn Nederlanders wel tolerant, terwijl deze verdraagzaamheid meestal in de verdrukking raakt wanneer het economisch slecht gaat (Prins, 1993). Immigranten worden op dergelijke momenten gezien als indringers en profiteurs (Kleinpenning \& Hagendoorn, 1993). De studies van Van Oudenhoven (2000) en van Van Oudenhoven et al. (1998) laten zien dat de Nederlanders het liefst willen dat immigranten assimileren of integreren, terwijl ze van mening zijn dat de meeste immigranten voorstander zijn van separatie. De aanwijzing dat immigranten hun eigen cultuur en taal willen behouden wordt opgevat als afkeuring van de Nederlandse cultuur. Dit wordt door de Nederlanders opgevat als een afwijking van het gewenste adaptatiepatroon (Arends-Tóth \& Van de Vijver, 2003). In het onderzoek van Van Oudenhoven et al. (2000) onder een representatieve steekproef van bijna 2400 proefpersonen in Nederland kwam naar voren dat autochtone Nederlanders vooral migranten waarderen die meer overeenkomsten met hen hebben. Autochtonen voelen zich meer aangetrokken tot allochtonen die meer op hen lijken.

Uit de onderzoeken van TNS/NIPO (1998 \& 2004) en Verkuyten \& Thijs (2002) blijkt dat veel Nederlanders van oordeel zijn dat immigranten zich te weinig en te langzaam aanpassen aan de Nederlandse samenleving. Volgens deze studies denken Nederlanders dat immigranten vooral bezig zijn met het behoud van eigen culturen (Arends-Tóth \& Van de Vijver, 2003).

In 2001 heeft de Universiteit Nijmegen een studie verricht naar de opvattingen van allochtonen en autochtone Nederlanders over elkaar. Uit de studie blijkt dat de twee groepen over verschillende zaken zoals migratiebeleid, godsdienstbeleving en discriminatie heel verschillend denken.

Uit onderzoek van Gijsberts \& Dagevos (2004) blijkt dat de mate van contact tussen de twee groepen belangrijk is voor wederzijdse acceptatie en begrip voor elkaar. Volgens deze studie is in Nederland ten opzichte van culturele aanpassing een grote afstand tussen de waarden van migranten en autochtonen. Coutts et al. (2007) zien contacten met andere herkomstgroepen als bevorderend voor de integratie.

Op een aantal aspecten van sociale samenhang vertonen niet-westerse allochtonen minder betrokkenheid bij de Nederlandse samenleving dan autochtonen. Zij participeren minder in organisaties, tonen minder interesse in de politiek, komen minder vaak opda- 
gen bij verkiezingen en hebben minder vertrouwen in de medeburger vergeleken met autochtonen. Ze hebben echter ongeveer net zoveel sociale contacten en proberen net zo vaak de politiek te beïnvloeden als autochtonen (Gijsberts \& Dagevos, 2010). De tweede generatie is actiever vergeleken met de eerste generatie en is meer betrokken bij de politiek dan de eerste generatie.

Uit een onderzoek van het German Marshall Fund in de VS en aantal EU-landen blijkt dat Nederlanders een positiever oordeel hebben over immigratie dan de meeste andere Europeanen. Nederland staat helemaal aan de top als het gaat om de vraag of legale immigranten mogen meestemmen bij de plaatselijke verkiezingen. Liefst $76 \%$ is daarvoor, terwijl het Europese gemiddelde op $63 \%$ ligt. Het beeld wordt wat genuanceerd als gevraagd wordt naar het verband tussen immigratie en misdaad. Gemiddeld vindt $52 \%$ van de Europeanen dat migratie tot meer misdaad leidt. In de VS is dat 47\%. Bij Nederlanders ligt dat percentage op $61 \%$. Alleen in Italië is men nog achterdochtiger (de Volkskrant, 18 november 2008).

Ik heb weinig literatuurstudies gevonden over het oordeel van de Nederlandse bevolking over de integratie van vluchtelingen in Nederland. Datzelfde geldt ook voor de Iraanse vluchtelingen. De reden hiervan zou te maken kunnen hebben met het feit dat de groep 'vluchtelingen' een vrij recente immigratiegroep is (van de jaren tachtig en negentig). De Nederlandse bevolking houdt minder contacten met Iraanse immigranten dan met vele andere immigranten. Daarnaast zou bij immigranten ook sprake kunnen zijn van beeldvorming over de Nederlanders en de Nederlandse gezinnen. Veel allochtonen bekritiseren bijvoorbeeld de wederzijdse relatie tussen kinderen en hun ouders in Nederland. Zakelijkheid, egoïsme en gebrek aan genegenheid worden gezien als een veelvoorkomend patroon bij de Nederlandse gezinnen. Zakelijkheid en afstandelijkheid van de Nederlanders beperken zich niet tot het gezin, maar komen ook voor in veel interpersoonlijke contacten.

Niet-westerse allochtonen van 15 jaar of ouder hebben over het algemeen minder vertrouwen in andere mensen dan autochtonen. De tweede generatie allochtonen heeft al meer vertrouwen in anderen dan de eerste generatie. Voor alle allochtone groepen geldt dat de tweede generatie zichzelf vaker als Nederlander beschouwt. Daarnaast blijkt dat de tweede generatie actiever is in clubverband en meer betrokken is bij de politiek dan de eerste generatie (Gijsberts \& Dagevos, 2010).

Nederlanders hebben een oprechte afkeer van alles wat neigt naar racisme, maar dit neemt niet weg dat de Nederlander meer etnocentrisch is dan hij denkt en zichzelf vergeleken met buitenlanders superieur voelt.

In deze studie is de respondenten de vraag voorgelegd hoe zij aspecten als zakelijkheid en afstandelijkheid in hun interacties met de Nederlanders en met hun begeleiders ervaren. Ook heb ik hun gevraagd of deze aspecten effect hebben gehad op hun oordeel over hun begeleiding naar integratie. Deze aspecten zijn niet in het (kwantitatieve) onderzoeksmodel 1 verwerkt. In (kwalitatief) onderzoek 2 komen aspecten als zakelijkheid, afstandelijkheid, cultuurverschil en discriminatie wel in beeld. 


\section{8 $\quad$ Beeldvorming en aanverwante begrippen}

Mensen zijn over het algemeen geneigd om aan hun sociale omgeving bepaalde eigenschappen toe te kennen. Ze veronderstellen dat bepaalde groepen over collectieve eigenschappen beschikken. Het toekennen van die eigenschappen kan op basis van verschillende kenmerken van die groepen plaatsvinden, zoals religie, woonplaats, sekse en ras. De negatieve opvattingen ten opzichte van bepaalde groeperingen zouden consequenties kunnen hebben voor deze groepen. Beeldvorming wordt beschreven als opvattingen en oordelen die mensen hebben over zichzelf en hun eigen groep en cultuur alsook over andere groepen en hun cultuur (Shadid, 1998). Stereotypen, vooroordelen, discriminatie, racisme en etnocentrisme worden gezien als negatieve voorbeelden van beeldvorming.

Stereotypen worden gedefinieerd als een set van vaste opvattingen over de eigenschappen van een andere groep. Vooroordeel wordt beschreven als een houding tegenover de leden van de andere groep, waarbij de richting van de evaluatie overwegend negatief is (Doosje et al., 1996).

Sommige auteurs zien deze twee begrippen als synoniem. Discriminatie wordt beschreven als ongelijke behandeling van een enkeling of van een groep op grond van arbitraire kenmerken als ras, sekse, etniciteit en culturele achtergrond. Het verbod op discriminatie is als een basisbegrip van mensenrechten wereldwijd geaccepteerd. Internationale verdragen veroordelen discriminatie op grond van geboorte, ras, geloof, geslacht, taal, sociale herkomst en status. Discriminatie heeft nauwe banden met etnocentrisme en vooroordelen.

In tegenstelling tot vooroordelen en discriminatie gaat het bij racisme om een ideologie die gebruikt wordt om de hiërarchische ordening van groepen op basis van raciale, etnische of culturele criteria te ordenen. Uitspraken zoals 'buitenlanders moeten het land uit, want Nederland is vol' of 'eigen volk eerst' of 'houd Nederland blank en schoon' zijn uitingen van racistische opvattingen. Ze duiden op een rechtvaardiging van de uitsluiting van bepaalde groepen op grond van raciale of etnische criteria.

Vollebergh (2000) definieert etnocentrisme als het superieur achten van de eigen autochtone groep en de eigen cultuur boven die van etnische minderheden (vooroordelen), het bevoordelen van autochtonen boven etnische minderheden bij de verdeling van schaarse goederen (bijvoorbeeld huisvesting, arbeidsmarkt), en/of het buitensluiten van allochtonen bij meer sociale aangelegenheden, zoals sociale steun of zorg. Het onderscheid maken tussen de eigen groep (ingroup) en de andere groep (outgroup), de anderen tot buitenstaanders maken en om die reden buitensluiten, wordt als kern gezien voor het tot stand komen van discriminatie en etnocentrisme. Naarmate bepaalde etnische groeperingen als vreemder worden ervaren, zullen zij ook sterker als 'outgroup' worden beschouwd en kan de houding ten opzichte van deze groep negatiever worden.

Over het algemeen wordt aangenomen dat naarmate mensen negatiever over etnische minderheden denken, ze ook in hun gedrag sterker zullen discrimineren. Mensen die discriminerende handelingen verrichten, zullen ook negatiever over etnische minderheden denken (Bovenkerk, 1978; Vollebergh, 2000). 
In de studies van Vollebergh $(1996,2000)$ wordt de mening van autochtonen over allochtonen bestudeerd. De etnische discriminatie wordt in zijn studie afgeleid uit het antwoord op de volgende vraag: hoe zou onder de conditie van schaarste de verdeling van de belangrijkste maatschappelijke hulpbronnen (zoals huisvesting en arbeidsmarkt) moeten plaatsvinden?

Vollebergh concludeerde uit zijn studies dat bij allochtone jongeren 'ervaren discriminatie en etnocentrisme' in de Nederlandse samenleving de twee belangrijkste factoren zijn die invloed uitoefenen op de negatieve attitudes en gedragingen van de jongeren. Ervaren discriminatie gaat vooral gepaard met meer militante reacties en met gevoelens van verbondenheid met eigen etnische groepen. Jongeren gaan dan kiezen voor strategieën die verbonden zijn met 'zelfuitsluiting' en bewust afzien van mogelijkheden die de Nederlandse samenleving biedt. Het gevolg hiervan zou kunnen zijn dat deze groep in een marginaliseringspiraal terechtkomt en zo de voorhoede vormt van bredere lagen gemarginaliseerde etnische groepen aan de onderkant van de samenleving.

Uit het bovenstaande is de conclusie gerechtvaardigd dat negatieve beeldvorming effect kan hebben op de mate waarin vluchtelingen zich rechtvaardig behandeld voelen. Vooral bij het proces van begeleiding is het belangrijk dat mensen het gevoel krijgen niet negatief beoordeeld te worden vanwege hun persoonlijke kenmerken. Negatieve beeldvorming kan ertoe leiden dat vluchtelingen zich machteloos voelen, hun vertrouwen in het proces van begeleiding verliezen en zich verder uitgesloten voelen van de Nederlandse samenleving.

In deze studie zijn, zoals ik eerder heb aangegeven, de culturele aspecten niet meegenomen in het onderzoeksmodel. Ik heb wel in onderzoek 2 gerichte vragen gesteld over de ervaring van de respondenten met culturele verschillen en hun persoonlijke beleving van discriminatie.

\section{Integratie of sociale uitsluiting}

De kans op integratie van immigranten wordt groter als zij een beroep mogen doen op steunbronnen in hun omgeving. Deze mogelijkheden kunnen uit hun eigen groep komen of uit de dominante groep. Berry $(1992,2001)$ veronderstelt dat migranten die in het acculturatieproces niet voldoende sociale contacten onderhouden met de mensen uit hun omgeving, het gevaar lopen dat ze in een isolement terechtkomen. De kans is groot dat ze zich gaan afscheiden van de samenleving. Volgens Berry zijn voor echte integratie zowel stevige contacten met de eigen sociale groep noodzakelijk als contacten met de leden van het gastland.

Het effect van uitsluitingsmechanismen moet niet worden onderschat. Het woord betekent in de meest algemene zin: er niet bij horen. Sociale uitsluiting wordt in drie vormen verdeeld:

1. Er niet bij mogen horen. 
2. Er niet bij kunnen horen.

3. Er niet bij willen horen.

De dominante groep ziet soms heel snel immigranten als bedreiging voor haar eigen waarden en normen. Een negatieve waardering van de normen en waarden van de immigranten door de dominante groep, zou kunnen leiden tot sociale uitsluiting. De uitsluiting vindt plaats op diverse gebieden in de samenleving, zoals arbeidsmarkt, informele relatienetwerken, media en onderwijs. Rath (1999) noemde dit proces ten aanzien van nieuwkomers 'verkleining': een proces waarbij bepaalde groepen tot etnische minderheden worden gemaakt. De definitie van bepaalde groepen als risicogroepen is ook een subtiel uitsluitingsmechanisme (Can \& Voordouw, 2001). Lindencrona et al. (2008) constateren dat discriminatie, verlies van status en vervreemding risicofactoren voor asielzoekers in Zweden vormden. Een relatief goede geestelijke gezondheid van vluchtelingen bleek onder meer samen te hangen met een groter materieel welzijn na de gedwongen migratie (eigen huisvesting, economische mogelijkheden), minder statusverlies en minder acculturatiestress (Porter \& Haslam, 2005).

\subsection{Iran}

\subsubsection{Schets van land en volk}

Iran is met $1.648 .000 \mathrm{~km}^{2}$ op 16 landen na het grootste land van de wereld. Het land heeft 65,9 miljoen inwoners. Het totale inwonertal is inclusief 1,4 miljoen vluchtelingen uit Afghanistan en 600.000 uit Irak. Sinds de Islamitische Revolutie in 1979 zijn enkele miljoenen burgers het land uit gevlucht. Verschillende etnische bevolkingen die in Iran wonen, spreken verschillende talen. De officiële taal van het land is het Farsi.

Meer dan 60\% van de populatie bestaat uit Perzen (inclusief de etnische groepen Gilaki, Mazandarani en Loren). Daarnaast wonen er in Iran ook Azaries (24\%), Koerden (7\%), Arabieren (3\%), Baloetsji's (2\%), en Turkmenen (2\%). Iran heeft een zeer jonge populatie: $70 \%$ is onder de 30 jaar.

De islam is de officiële godsdienst van Iran. Islamitische gelovigen zijn onderverdeeld in sjiieten en soennieten, waarvan 85\% sjiieten. Daarnaast zijn er bahais, Armeense en Assyrische christenen, joden en zoroastriërs (samen 1\%), en overigen (4\%). Met uitzondering van de bahais worden ze als godsdienstminderheden erkend als 'volkeren van het Boek'. Dit betekent dat zij over eigen godshuizen, rechtbanken en onderwijsinstellingen mogen beschikken. Bahais worden als bedreiging van de stabiliteit van Iran en de islam gezien en worden vervolgd.

\subsubsection{Het politieke systeem}

Vanaf 1979 en na het vertrek van koning Mohamed Reza Pahlavi is Iran een islamitische republiek geworden. Het sociale, politieke en economische bestel is gebaseerd op de 
islam. Aan het hoofd staat de geestelijke leider en daarna de president. De geestelijke leider is voor het leven benoemd. Leger, politie, de rechterlijke macht en de president zijn ondergeschikt aan hem.

Het parlement bestaat uit 290 rechtstreeks voor vier jaar gekozen vertegenwoordigers met zeer beperkte macht. Hun macht wordt beperkt door 'de Raad van Toezicht'. Deze heeft een vetorecht over alle parlementsbesluiten die in strijd zouden kunnen zijn met het beginsel 'velayate faqih' (een sjiitische wetgeving).

Op politiek gebied is de oppositie te verdelen in aanhangers van de monarchie, linkse partijen, moslimgroeperingen en nationaal-liberale bewegingen.

Sinds de Islamitische Revolutie hebben ongeveer drie miljoen Iraniërs hun land verlaten. De meerderheid van de politieke vluchtelingen is afkomstig uit de stedelijke middenklasse. De groep die aan het eind van de jaren tachtig en later naar Nederland is gekomen, bestaat uit twee groepen: politieke vluchtelingen en personen die genoeg hebben van het door de islam gedomineerde leven in Iran, en een betere toekomst in een meer westerse leefstijl willen opbouwen.

\subsubsection{Cultuur en religie}

De nationale, Perzische cultuur is sterk en gaat 2500 jaar terug. Cultuur en geschiedenis zijn voor elke Iraniër belangrijke wortels waar men trots op is. Die trots op de rijke traditie van het Perzische volk wordt in de volksaard gecombineerd met verzet tegen vreemde overheersingen waar het volk de hele geschiedenis mee te maken heeft gehad.

In Iran bestaat er een groot verschil tussen het leven in de stad en op het platteland. Ongeveer de helft van de bevolking woont in stedelijke gebieden waar voorzieningen zijn zoals we die in Nederland kennen. Het leven op het platteland kent daarentegen een traditionele structuur en levenswijze. Daarnaast is er ook sprake van minder welvaart en meer financiële beperkingen. De invloed van de islam is op het platteland veel groter dan in de grote steden.

De hedendaagse Iraanse cultuur wordt beschouwd als een mengeling van een historische volksidentiteit, zoroastrische elementen, islamitische invloeden en hedendaagse westerse denkbeelden. Dit alles heeft bijgedragen aan de ontwikkeling van het land, enerzijds tot een semitraditionele samenleving, anderzijds tot een semimoderne samenleving.

Een belangrijk aspect is het gevoel van verbondenheid met en verplichtingen ten opzichte van familienetwerken. Dit vormt een intern netwerk voor ondersteuning. De familie staat centraal in het leven van Iraniërs. Het respect voor de ouderen binnen de familie is groot. Bij het nemen van beslissingen hebben de ouderen de meeste zeggenschap.

Sinds de Islamitische Revolutie speelt de islam op alle terreinen van de samenleving en de cultuur een overheersende rol. Door de islamitische wetgeving is de vrouw ondergeschikt aan de man geworden. Dit heeft geleid tot het ontnemen van veel rechten die vrouwen vóór die tijd en vooral in de tijd van de monarchie hadden. Vrouwen zijn uitgesloten van functies in de rechterlijke macht, de religie en het leger. 


\subsubsection{Iraniërs in Nederland}

Iran behoort tot de top tien van landen waarvan personen politiek asiel vragen in Nederland. Het CBS vermeldt dat het aantal genaturaliseerde Iraniërs per 1 januari 200011.731 bedraagt. In 2004 vermeldde het CBS dat er 28.438 Iraniërs in Nederland waren. Het vluchten heeft diverse redenen, zoals vrees voor vervolging en bedreigingen, en het verlies van vrijheid door het fundamentalistische regime. Op 1 januari 2010 woonden er 39.000 Iraniërs in Nederland (CBS, 2010). In 2011 woonden er 32.777 Iraanse vluchtelingen met een verblijfsvergunning in Nederland, van wie er 25.932 tot de eerste generatie behoorden en 6845 tot de tweede generatie.

Gevluchte Iraniërs hebben over het algemeen een goede opleiding genoten. De meeste van hen zijn afkomstig uit de grote steden en spreken Engels. Zij behoorden in Iran tot het moderne deel van de bevolking en hadden veelal een westerse levensstijl. Het verwerven van de materiële positie die men in Iran tot zijn beschikking had, is meestal niet in Nederland mogelijk. Belangrijke redenen hiervan zijn aspecten als gesloten economie, het niet goed beheersen van de Nederlandse taal en kwalificatie-eisen voor beroepen. Bovendien is het gebrek aan relatienetwerken een moeilijk te slechten barrière.

Uit het Jaarrapport integratie (2004) blijkt dat Iraanse vluchtelingen graag meer contacten wensen met de Nederlanders dan met hun eigen groep (38\% tegenover $24 \%$ ). Verder blijkt dat de Iraniërs dichter bij de Nederlanders staan ten opzichte van hun waarden en normen dan vele andere vluchtelingengroepen. Boven aan de integratiekaart van het Centraal Bureau voor de Statistiek (CBS) en het Wetenschappelijk Onderzoeks- en Documentatie Centrum (WODC) staan Iraniërs. Ze integreren het meest in Nederland, gevolgd door Joegoslavische en Afghaanse vluchtelingen.

Iraanse vluchtelingen zijn over het algemeen hoog opgeleid en hebben minstens de middelbare school afgerond (vergelijkbaar met de havo in Nederland). Gijsberts \& Dagevos $(2009,2010)$ schetsen Iraanse Nederlanders als een overwegend hoogopgeleide en moderne groep. Het gaat duidelijk beter met Iraniërs dan met de vele andere migrantengroeperingen. Bij de Iraniërs is er duidelijk sprake van elitemigratie. Dit is zichtbaar op uiteenlopende terreinen. Zo presteren de kinderen van de Iraanse migranten uitstekend in het onderwijs; het aandeel jongeren met een Iraanse achtergrond dat op havo/vwo zit, is zelfs wat hoger dan bij autochtone Nederlandse jongeren. Dat het om een moderne groep gaat, kan worden afgeleid uit het feit dat Iraans-Nederlandse vrouwen weinig kinderen krijgen, en ook op latere leeftijd. Zelfs autochtone Nederlandse vrouwen krijgen meer en eerder kinderen dan Iraans-Nederlandse vrouwen. Ook opvallend is het hoge aandeel personen van Iraanse afkomst met de Nederlandse of een dubbele nationaliteit. Dit betekent nog niet dat bij de Iraans-Nederlandse groep gesproken kan worden van een geslaagde en voltooide integratie. Van de Iraanse Nederlanders van 15-65 jaar zit 18\% in de bijstand (tegen 1,6\% van de autochtone Nederlanders). Hoewel dit aandeel onder invloed van een langere verblijfsduur en conjuncturele ontwikkeling in de afgelopen tien jaar is gedaald, is het dus nog steeds zeer hoog. Opvallend is verder het hoge aandeel Iraans-Nederlandse ondernemers. 
Onder Iraniërs in Nederland bevinden zich betrekkelijk veel jongeren. Ongeveer $40 \%$ is dertiger of veertiger. Het merendeel van hen is gedurende de afgelopen 25 jaar als asielzoeker naar Nederland gekomen. In 2010 deden Iraanse kinderen het in het derde leerjaar van het voortgezet onderwijs bijna net zo goed als autochtone kinderen. Van de tweede generatie Iraanse leerlingen zitten zelfs bijna drie op de vijf leerlingen op de havo of het vwo. Onder Iraniërs in Nederland bevinden zich betrekkelijk veel jongeren.

Op de arbeidsmarkt blijkt dat ze net als vele andere vluchtelingen moeilijk een baan kunnen vinden die bij hun kwaliteiten en opgedane kennis en kunde past. Dit heeft vooral te maken met kwalificatie-eisen die in Nederland gesteld worden. Het gesloten karakter van de arbeidsmarkt, de sollicitatieprocedure en het niet goed beheersen van de Nederlandse taal worden ook als belangrijke oorzaken aangegeven. Uit de gegevens van het Jaarrapport integratie (2004) blijkt dat bijna 43\% van de Iraniërs een betaalde baan van 12 uur of meer per week heeft. Bij Iraniërs bedraagt de arbeidsdeelname van vrouwen in 2009 42\%. Dat is veel hoger dan bij de andere vluchtelingengroepen. Iraniërs vormen met $45 \%$ in 2009 het hoogste aandeel van de vluchtelingengroepen dat als werknemer in loondienst is. Het sociaaleconomische integratieproces van Iraniërs, die gemiddeld al het langst in Nederland zijn, lijkt van de vier vluchtelingengroepen het meest succesvol verlopen te zijn. Ze zijn goed vertegenwoordigd in het middelbaar en hoger onderwijs. Dit geldt ook voor hun deelname op de arbeidsmarkt: onder zelfstandigen is hun aandeel zelfs bijzonder hoog. Dit komt waarschijnlijk doordat de Iraanse vluchtelingen een overwegend hoogopgeleide en moderne groep zijn (Gijsberts \& Dagevos, 2009).

Op het terrein van de gezondheidszorg blijkt dat het Nederlandse gezondheidsstelsel in vele aspecten afwijkt van het Iraanse gezondheidssysteem. De structuur en de functie van de Nederlandse geestelijke gezondheidszorg zijn ook voor de meeste Iraanse vluchtelingen niet echt zaligmakend. Veel Iraanse vluchtelingen lijden net als vele andere vluchtelingen aan depressie en stressverschijnselen. Een paar belangrijke factoren die hieraan ten grondslag liggen zijn: vlucht en het acculturatieproces, de meegemaakte trauma's en andere stressvolle gebeurtenissen zowel in Iran als in Nederland, het verlies van sociale netwerken, het gemis van dierbaren die men in Iran heeft achtergelaten en de werkloosheid. Wat de sociale contacten betreft, blijkt dat bij Iraniërs minder sprake is van een collectief 'identiteitsgevoel' dan bij andere vluchtelingenpopulaties. Iraniërs zijn meer gewend om vast te houden aan de eigen individuele principes. Een andere eigenschap van Iraanse vluchtelingen is het actief ontwikkelen van sociale relaties buiten hun eigen gemeenschap. Hoogopgeleiden zoeken en vinden gemakkelijker aansluiting met Nederlanders dan met landgenoten. Dit zou vooral te maken kunnen hebben met het feit dat de Iraanse vluchtelingen van huis uit bekend zijn met de Europese cultuur en de wijze van leven. Gemengde huwelijken tussen Iraniërs en Nederlanders komen relatief veel voor. Gemengde huwelijken tussen de autochtone bevolking en bepaalde etnische groepen worden vaak gezien als een indicatie voor de mate waarin de betreffende etnische groep in de Nederlandse samenleving geaccepteerd en geïntegreerd is (Roelandt \& Veenman, 1991; Hessels, 2002). 
Al deze factoren wijzen erop dat Iraniërs zich langzaam maar zeker in Nederland een plek verwerven en dat de meeste Iraniërs goed thuis zijn geraakt in de Nederlandse samenleving én bekend zijn met de regels, gebruiken en gewoontes van die samenleving (Van den Tillaart et al., 2000).

\subsubsection{Het effect van het cultuurverschil op kansperceptie}

De Iraanse vluchtelingen in Nederland zijn zeer divers wat betreft hun etnische, religieuze en politieke achtergrond. Een gemeenschappelijk kenmerk van deze groep van vluchtelingen is dat de meeste leden afkomstig zijn uit de grote steden. Ze zijn relatief vrij opgevoed met de nadruk op zelfstandigheid. In Iran hadden ze een westerse levensstijl en ook in normen, waarden en politiek denken waren ze westers georiënteerd. Iraanse vluchtelingen zijn als individu naar Nederland gevlucht en gaan zo ook om met cultuurverschillen. Deze westers gerichte oriëntatie maakt het proces van integratie voor Iraanse vluchtelingen minder problematisch. Iraanse vluchtelingen in Nederland, voornamelijk jongeren, zijn gericht op het volgen van onderwijs en hebben hoge ambities. Volgens De Vries (2002) hebben Iraniërs ambitieuze verwachtingen van het verblijf in Nederland. Impliciete verwachtingen zijn: het recht op een zekere 'compensatie' na het ondergane leed, respect voor en erkenning van hun idealen en status, de kans zich te ontplooien en op materieel niveau een vergelijkbare positie als in Iran te verwerven. Deze verwachtingen en een zekere mate van trots en zelfrespect zorgen ervoor dat Iraniërs veel assertiever zijn ten opzichte van functionarissen en hulpverleners dan andere vluchtelingen.

De hooggespannen verwachtingen over respect, studie, werk en status worden zelden ingelost en botsen soms met het zelfrespect en de trots, en de rechten die ze menen te hebben. Dat werkt nogal eens contraproductief. Het is voor veel Iraniërs moeilijk om een middenweg te vinden tussen enerzijds vasthoudend zijn en zich niet laten ontmoedigen, en anderzijds flexibel zijn en zich neerleggen bij wat haalbaar is.

Gezien het feit dat Iraniërs over het algemeen 'integratie en assimilatie' in Nederland nastreven, kunnen we ze plaatsen onder de categorie overeenstemmingsfit in het Interactieve Acculturatie Model (IAM).

Uit bovenstaande blijkt verder dat het cultuurverschil tussen Iran en Nederland zo gering is dat het gemakkelijk overbrugd kan worden. Daarom verwacht ik weinig conflicten tijdens het integratieproces. Dit komt door aspecten als individualisme, een westers gerichte opvoeding en geïnteresseerd zijn in de westerse levensstijl. Deze aspecten heeft de meerderheid van gevluchte Iraniërs van huis uit meegekregen.

Wat het waarnemen van de kansen betreft, ligt naar mijn mening de kwestie wat ingewikkelder. Dit geldt vooral voor Iraanse vluchtelingen die in het Nederlandse profiel van succes passen. Het verwachtingspatroon dat nogal eens als hoog wordt beschreven, hoge ambities, assertiviteit, zelfstandigheid en zelfbewustheid gaan niet gepaard met gemakkelijk tevreden zijn. Dit zou leiden tot 'minder gauw genoegen nemen met de begeleiding die ze krijgen'. 


\section{Hoofdstuk 4}

\section{De onafhankelijke variabelen: procedurele rechtvaardigheid, inspraak en vertrouwen bij de begeleiding naar integratie}

Iraanse vluchtelingen zijn uit hun land verdreven vanwege sociale en politieke onderdrukking. Voor een groot deel van hen is het tot stand brengen van een rechtvaardig (politiek, sociaal en economisch) systeem in Iran een levenslang ideaal waarnaar ze hebben gestreefd. Voor vele Iraanse vluchtelingen is het een levenslange droom om in een rechtvaardige wereld te leven. Een wereld die geen onderdrukking kent en waarin iedereen gelijke en eerlijke kansen krijgt. Dit ideaal maakt deel uit van hun persoonlijke identiteit. Om hun ideaal te realiseren, hebben ze in de gevangenis gezeten, werden ze gemarteld en mishandeld en zijn ze hun dierbaren kwijtgeraakt. In het kader van hun begeleiding zal naar mijn mening hun persoonlijke ervaring met rechtvaardigheid en daaraan gebonden aspecten zoals vertrouwen en inspraak een bijzondere rol spelen. De denkbeelden van de groep vluchtelingen over en de emotionele betekenis van aspecten zoals rechtvaardigheid, inspraak en vertrouwen liggen soms ver van de denkbeelden van autochtone Nederlanders. De wijze waarop de respondenten de begeleiding ervaren, houdt naar mijn mening duidelijk verband met hun oordeel over de begeleidingsfactoren. In dit hoofdstuk beschrijf ik kort de begrippen rechtvaardigheid en distributieve en procedurele rechtvaardigheid. Daarnaast ga ik in op de verwante aspecten van het begrip procedurele rechtvaardigheid die in deze studie centraal staan, namelijk vertrouwen en inspraak.

\subsection{Rechtvaardigheid: definitie van begrip}

Verschillende wetenschappelijke domeinen hebben zich met het thema 'rechtvaardigheid' beziggehouden, onder andere filosofie, politicologie, recht, sociale psychologie en arbeids- en organisatiepsychologie.

Het begrip rechtvaardigheid is niet gemakkelijk te definiëren. Plato bracht rechtvaardigheid in verband met arbeidsverdeling. ledere persoon vervult één maatschappelijke functie, de functie waarvoor hij aanleg heeft. Volgens Plato zijn de maatschappelijke verhoudingen rechtvaardig als de geldverdienende, de militaire en de regerende groep zich elk tot haar eigen zaken beperkt en haar eigen maatschappelijke taak vervult. Een hiërarchische orde speelt in het standpunt van Plato een belangrijke rol.

Aristoteles (384-322 voor Chr.) was een groot voorstander van democratie. Democratie in haar ware vorm is gebaseerd op het erkende beginsel van democratische gerechtigheid. Dit betekent dat ieder mens gelijk behoort mee te tellen. De gelijkheid houdt volgens hem in dat de rijken geen groter aandeel in de regering behoren te hebben dan de 
armen en dat ze niet de enige heersers behoren te zijn. In een democratische staat hebben alle burgers gelijke rechten. Democratie is gebaseerd op rechtvaardigheid. Allen behoren gelijk te regeren naar gelang van hun aantallen. Volgens Aristoteles is gelijkheid nauw verwant met rechtvaardigheid. Maatschappelijke ongelijkheid is volgens Plato en Aristoteles dé achtergrond van revoluties (Hoogerwerf, 2001).

In de laatste decennia is onderzoek naar de perceptie van rechtvaardigheid in sterke mate een aandachtspunt geworden van de sociale wetenschappen. Men heeft verschillende theorieën ontworpen waarin werd geprobeerd de kernbegrippen over dit thema te definiëren.

Greenberg (1987) maakt onderscheid tussen proactieve en reactieve rechtvaardigheid. Proactieve rechtvaardigheid behelst de vraag tot op welke hoogte mensen rechtvaardigheid nastreven in de beslissingen die zij nemen. Reactieve rechtvaardigheid gaat na hoe mensen reageren op de waargenomen (on)rechtvaardigheid van dingen die hun wordt aangedaan.

Van den Bos $(2002,2007)$ maakt onderscheid tussen prescriptieve en descriptieve theorieën. Volgens de auteur wordt in prescriptieve theorieën aangegeven wat (on)rechtvaardigheid is. Voorbeelden hiervan treft men aan in de filosofie. Wanneer filosofen zich bezighouden met sociale rechtvaardigheid, construeren ze theorieën die aangeven welke gebeurtenissen of handelingen als rechtvaardig moeten worden beschouwd en welke voorvallen of acties als niet rechtvaardig moeten worden aangeduid.

Descriptieve inventarisaties van sociale rechtvaardigheid proberen te beschrijven wat mensen rechtvaardig of onrechtvaardig vinden. Voorbeelden van een dergelijke manier om rechtvaardigheid te beschrijven treffen we aan in de sociale psychologie. Men probeert onder meer na te gaan wat mensen rechtvaardig vinden en hoe zij tot een oordeel komen.

\subsubsection{Distributieve en procedurele rechtvaardigheid}

De theorievorming over rechtvaardigheid heeft zich in twee belangrijke richtingen ontwikkeld: distributieve (verdelende) en procedurele rechtvaardigheid.

In de jaren zestig interesseerden sociaal psychologen zich vooral voor het concept distributieve rechtvaardigheid. Onderzoekers richtten zich op twee aspecten: op de door de persoon ervaren rechtvaardigheid van de verdeling van uitkomsten (straf, beloning, status en dergelijke) én op de reacties van mensen op deze verdeling. Het verwachtingspatroon met betrekking tot uitkomsten speelt bij alle studies op dit terrein een belangrijke rol.

Halverwege de jaren zeventig wordt de aandacht van sociaal psychologen echter niet alleen gericht op de waargenomen rechtvaardigheid van de uitkomsten van de sociale interacties, maar ook op de wijze waarop uitkomsten worden bepaald (Deutsch, 1975; Thibaut \&Walker, 1975, 1978; Leventhal, 1976, 1980). Tevredenheid over een procedure is niet slechts een functie van distributieve aspecten (de ervaren rechtvaardigheid van de verkregen uitkomst), maar ook van de waargenomen rechtvaardigheid van de procedure die tot de uitkomsten leidt. Het gegeven dat de aspecten van procedurele rechtvaardigheid 
onafhankelijk van de uitkomsten invloed uitoefenen op de ervaren tevredenheid over de gang van zaken, is veelvuldig aangetoond (Latour, 1978; Lind et al., 1980; Van den Bos et al., 1997).

Het belang van procedurele rechtvaardigheid beperkt zich niet tot het veld van sociale psychologie. Uit veldonderzoeken blijkt dat procedurele rechtvaardigheid een zeer cruciale rol speelt bij de contacten tussen burgers en politiek (Tyler \& Folger, 1980; Tyler, 1988; Van den Bos, 2005, 2007), in de evaluatie van politieke leiders door burgers (Tyler et al., 1985) en in de beoordeling van docenten door studenten.

Voor zover mij bekend is, is er in Nederland geen studie verricht naar het subjectieve oordeel van vluchtelingen over procedurele rechtvaardigheid: hoe ervaren vluchtelingen de begeleiding naar integratie en in hoeverre beleven ze deze begeleiding als procedureel rechtvaardig?

Naar mijn mening is het voor een effectieve begeleiding zeer belangrijk om een correct beeld te hebben van de persoonlijke beleving van de groep vluchtelingen van de begeleiding die ze wensen te krijgen. Men is te vaak en te eenzijdig bezig met beelden en ideeën die gebaseerd zijn op de uitgangspunten van autochtone Nederlanders. Dit zou ertoe kunnen leiden dat de behoeften van de groep allochtonen onvoldoende onderkend worden en er waarschijnlijk (in vele gevallen) eenzijdige beleidsbeslissingen genomen worden.

\subsection{Het belang van rechtvaardigheid}

Het onderzoek naar sociale rechtvaardigheid heeft in eerste instantie plaatsgevonden in het bedrijfsleven en in het rechtssysteem van Amerika. Langzamerhand heeft de studie op dit terrein zich uitgebreid naar andere velden. Deze ontwikkeling lijkt vanzelfsprekend te zijn: overal waar mensen wonen en met elkaar en met de autoriteiten in contact komen, geven zij ook hun oordeel over de sociale rechtvaardigheid.

Van den Bos et al. (1998) veronderstellen dat mensen vaak onzeker zijn over hun relatie met leidinggevenden en andere autoriteiten. Dit komt onder andere omdat autoriteiten macht over en/of invloed op hen kunnen uitoefenen waardoor de mogelijkheid bestaat dat de autoriteiten hun macht zullen misbruiken of ondergeschikten zullen uitsluiten van belangrijke verbanden (Tyler et al., 1996). Mensen willen daarom graag weten of zij hun leidinggevenden kunnen vertrouwen (Van den Bos, 2001).

Voor de groep vluchtelingen en asielzoekers ligt de kwestie 'macht en vertrouwen' zeer gevoelig en ingewikkeld. Vooral de asielzoekers bevinden zich in de eerste periode van hun verblijf in een zeer afhankelijke positie. Verschillende factoren, zoals onvoldoende kennis van de sociale sector, de taalproblematiek, onzekerheid over de toekomst, psychische trauma's en het verkeren in depressieve en angstige toestand, maken deze groep zeer afhankelijk van hun begeleiders.

De wijze waarop vluchtelingen door de autoriteit/begeleider behandeld en benaderd worden en de mate waarin dit als (on)rechtvaardig ervaren wordt, hebben invloed op hun 
gedachten, gevoelens, attitudes en gedragingen. Dit is een zeer gevoelig onderwerp voor vluchtelingen, gezien hun voorgeschiedenis en achtergrond. Ze willen graag weten of zij hun begeleiders kunnen vertrouwen. Directe informatie die vluchtelingen van hun begeleiders verkrijgen én de zeggenschap die zij hebben over het verloop van de begeleidingsprocedure, hebben naar mijn mening invloed op hun kanspercepties in Nederland.

Wanneer we ons bezighouden met ideeën en oordelen van mensen over rechtvaardigheid, weten we dat we met subjectieve ideeën te maken hebben die toch kunnen worden gedefinieerd op basis van enkele aspecten die hierna aan de orde komen.

\subsection{Aspecten van rechtvaardigheid}

Thibaut \& Walker (1978) komen in hun onderzoek naar rechtspraak tot de conclusie dat de ervaren rechtvaardigheid van uitspraken niet alleen beïnvloed wordt door de verkregen uitkomsten, maar ook door de gebruikte procedures bij de besluitvorming over de uiteindelijke uitvoering van de beslissingen. Ze onderscheiden twee elementen: procescontrole en beslissingscontrole in de besluitvorming.

Procescontrole gaat over de invloed die mensen hebben in de procedures, zoals inspraak, ook wel voice genoemd (Folger, 1977; Tyler et al., 1985; Early \& Lind, 1987; Cohen, 1988). Beslissingscontrole geeft de mate aan waarin mensen invloed hebben op de uiteindelijke beslissingen (Houldon et al., 1978; Thibaut \& Walker, 1975; Lind et al., 1983).

Leventhal (1980) noemt enkele elementen die tot rechtvaardige procedures behoren, zoals consistentie, corrigeerbaarheid, informatiekwaliteit en representativiteit. De relationele (Lind \& Tyler, 1988) en interactionele rechtvaardigheid (Bies \& Moag, 1986) hebben ook relaties met aspecten als inspraak en vertrouwen.

Uit diverse studies blijkt dat er verbanden bestaan tussen de aspecten van procedurele rechtvaardigheid en tevredenheid over trajecten en/of organisaties (Naumann, 1998; Reichle \& Gefke, 1998; Hart, 1998; Gilson, 2001; Erdogan et al., 2001; Huffman \& Cain, 2001; Naumann \& Bennett, 2000; Lemons \& Jones-Coy, 2001).

In de studies van Bakker et al., 2000; Taris et al., 2001; Karregat \& Steensma, 2005; Kawachi, 2006; Vermunt \& Steensma, 2005; Ybema et al., 2006 en Ybema, 2007 zijn relaties gevonden tussen procedurele rechtvaardigheid, geestelijk welbevinden van mensen in organisaties en het ontstaan van stressklachten.

Van Dijk et al. (2001) constateerden in hun studie dat asielzoekers ontevreden waren over de geboden zorg. Ze klaagden dat ze niet gehoord werden en slecht behandeld werden. Het frequent voorschrijven van paracetamol wordt ervaren als een teken van desinteresse en ontkenning van de gezondheidsklachten door de zorgverleners.

In de studie van Goosen \& Gerritsen (2007) gaf 60\% van de respondenten aan welke verbeteringen zij in de zorgverlening wensen. De onderzoeksgroep bestond uit Afghaanse, Iraanse en Somalische asielzoekers. De meest frequent genoemde verbeteringen waren: serieus genomen worden, geloofd worden, gerespecteerd worden, beter behandeld wor- 
den (met medicatie, snellere behandeling), meer aandacht krijgen, sneller doorverwezen worden, gehoord worden, betere bereikbaarheid en hetzelfde worden behandeld als Nederlanders.

Feldmann (2007) constateerde dat vluchtelingen uit Somalië en Afghanistan de technische vaardigheden van huisartsen niet in twijfel trekken, maar in de interactie met de huisarts (het opbouwen van) vertrouwen missen.

Ook de mate van betrouwbare informatie die mensen tot hun beschikking hebben, heeft invloed op het oordeel dat mensen vellen over de procedurele rechtvaardigheid. Het oordeel over rechtvaardigheid van procedures is meestal in de zogenaamde informatieonzekerheid tot stand gekomen. Van den Bos $(1996,2002)$ en Van den Bos et al. (1997) tonen in hun studies aan dat rechtvaardigheidsoordelen sterk worden beïnvloed door procedurele rechtvaardigheidsinformatie. Wanneer mensen niet weten welke uitkomst een vergelijkbaar ander persoon heeft ontvangen, heeft procedurele rechtvaardigheid geen invloed op hun oordeel. Distributieve rechtvaardigheid heeft in dit geval wél invloed op hun oordeel. De informatie die mensen wel of niet voorhanden hebben, is van grote invloed op datgene wat als rechtvaardig of onrechtvaardig waargenomen en beoordeeld wordt. Informatieonzekerheid speelt een cruciale rol in het construeren van rechtvaardigheidsoordelen.

\subsubsection{Inspraak (voice)}

Uit diverse studies, zowel in de politiek als in organisaties, komt naar voren dat de mate van inspraak die mensen in de besluitvorming ervaren, een zeer belangrijke factor is bij het waarnemen van controle en tevredenheid over procedures (Lind \& Tyler, 1988).

Rechtvaardigheid in een procedure komt naar voren door interactie tussen mensen en de directe besluitvormer en/of autoriteit. Vooral de mate van inspraak die mensen in de besluitvorming hebben, speelt hierbij een belangrijke rol. Als men persoonlijk inspraak in een beslissing heeft, wordt de ervaren procedurele rechtvaardigheid groter en wordt ook de beslissing gemakkelijker geaccepteerd. Dit betekent dat mensen hun kansen en mogelijkheden positiever gaan beoordelen.

Wetenschappers hebben verschillende studies verricht om antwoord te verkrijgen op de vraag welke aspecten in een procedure door mensen als positief en motiverend worden ervaren (Lind, 1998; Lind et al., 1980; Lind \& Tyler, 1988; Tyler \& Lind, 1992). De bevindingen uit bijna alle studies duiden aan dat het oordeel over procedures positiever is naarmate mensen meer de mogelijkheid krijgen om hun mening te geven. Dit wordt in de literatuur betiteld als het 'inspraakeffect'.

Het effect van inspraak wordt door twee verschillende benaderingen verklaard: een instrumentele en een non-instrumentele verklaring.

Volgens de instrumentele verklaring leidt procescontrole tot een hogere procedurele rechtvaardigheid omdat dit tot een betere verdeling van resultaten voor het individu leidt. In de theorie van Leventhal (1980) is procescontrole een instrument om tot een betere verdeling van resultaten te komen. 
Een alternatief hiervoor is een benadering die in plaats van de opbrengsten het groepslidmaatschap van mensen centraal stelt. De non-instrumentele verklaring stelt dat inspraak van invloed is op procedurele rechtvaardigheid omdat de status van het individu binnen de groep wordt verhoogd (Lind \& Tyler, 1988; Tyler \& Lind, 1992). Op basis van de resultaten van deze studies is niet de controle over de beslissing, maar de positie binnen de groep bepalend voor de reacties van mensen in sociale interacties. Uit de studies van Hart (1998), Gilson (2001), Huffman \& Cain (2001), Erdogan et al. (2001) en Naumann \& Bennett (2000) bleek dat er positieve relaties bestaan tussen inspraak en de waargenomen procedurele rechtvaardigheid.

In deze studie is getracht om de relatie tussen inspraak en de perceptie van de kansen in beeld te brengen. Aan de respondenten zijn vragen gesteld over hun persoonlijke invloed op het proces van de begeleiding (inspraak), en de relatie tussen hun ervaren inspraak en hun kansperceptie om in Nederland succesvol te kunnen integreren.

\subsubsection{Vertrouwen}

In diverse studies op het terrein van de sociale wetenschappen en politiek wordt benadrukt dat bij iedere procedure waarin mensen betrokken zijn, het oordeel over (on)rechtvaardigheid van de gevolgde procedure een belangrijke factor is. Vooral het effect van vertrouwen in de autoriteit krijgt gewicht in de waarneming van procedurele rechtvaardigheid en tevredenheid over procedures.

Mensen leven en werken samen met anderen. In hun interacties met anderen speelt vertrouwen in de ander een centrale rol. Het sociale model vat vertrouwen op als een vorm van georiënteerdheid op anderen (Kramer \& Tyler, 1996). McAllister (1995) definieert vertrouwen als de mate waarin een persoon bereid is te handelen. Zijn handelen dient ook afgestemd te zijn op de waarden, handelingen en beslissingen van de ander.

Tyler \& Schuller (1990) noemen drie factoren als voorspellers van de mate van procedurele rechtvaardigheid: vertrouwen, controle over de beslissing (procescontrole en beslissingscontrole) en de interpersoonlijke communicatie.

De mate van vertrouwen wordt bepaald door de aandacht voor de behoeften van de persoon en de manier waarop verschillende meningen in de groep overwogen worden door de autoriteit (Lind, 1998; Tyler \& Lind, 1992; Nooteboom et al., 1997).

Vertrouwen is gebaseerd op de kennis die de persoon heeft over de ander. Informatie en communicatie spelen daarbij een belangrijke rol: hoe meer iemand van de ander weet, hoe beter men het gedrag van een ander kan voorspellen. Ook kennis van het verwachtingspatroon van die ander over ons is belangrijk.

Boon \& Holmes (1991) beschrijven vertrouwen als een positieve verwachting over het motief van de ander ten opzichte van zichzelf in risicovolle situaties. Bij een eerste ontmoeting is het duidelijk in hoeverre de ander te vertrouwen is. Vertrouwen in de ander is in dit geval vooral gebaseerd op angst voor de negatieve consequenties van handelen van de ander. Siegel et al. (1995) concluderen dat tussen vertrouwen en uitkomst (distributieve rechtvaardigheid) een significant interactie-effect bestaat. 
Rousseau et al. (1998) beschouwen vertrouwen als een psychologische toestand waarin het individu zich kwetsbaar opstelt. Deze kwetsbaarheid is gebaseerd op de positieve verwachtingen ten opzichte van de intenties, houding en het gedrag van de ander. Zij onderscheiden twee condities die noodzakelijk zijn voor het ontstaan van vertrouwen. Als eerste moet de situatie een bepaald risico met zich meebrengen en als tweede moet er onderlinge afhankelijkheid bestaan tussen het individu en de andere partij (Van Beek, 1999).

Aan vertrouwen zit, naast de bereidheid tot afstemming, een verwachtingsaspect. Mensen werken met anderen samen omdat zij de subjectieve verwachting (het vertrouwen) hebben dat datgene wat zij investeren niet door de ander wordt uitgebuit. Nooteboom et al. (1997) definiëren vertrouwen op basis hiervan als volgt: $X$ vertrouwt $Y$ in de mate dat $X$ verkiest om samen te werken met $Y$ op basis van de subjectieve verwachting dat $Y$ geen gebruik zal maken van gelegenheden die $X$ als schadelijk beschouwt, ook als dat in het belang van $Y$ is om dat te doen. Lemons \& Jones-Coy (2001), Von Grumbkow \& Ramaekers (2000b, 2004) en Syroit et al. (2007) zien duidelijke verbanden tussen vertrouwen, inspraak en de rechtvaardige procedures. In een recente studie onder asielzoekers uit Irak en Somalië blijkt dat vertrouwen een belangrijke factor is voor het slagen van medische begeleiding (Feldmann et al., 2007).

Uit het bovenstaande is de conclusie gerechtvaardigd dat in het proces van oordeelsvorming over rechtvaardigheid, vertrouwen zowel in interpersoonlijke relaties als in groepsverband een belangrijke rol speelt.

In deze studie is getracht het vertrouwen van vluchtelingen in het proces van begeleiding te meten. In onderzoek 1 heb ik de respondenten vragen gesteld over diverse aspecten van vertrouwen enerzijds, en de relatie tussen vertrouwen in hun begeleiding en hun perceptie van kansen op succesvolle integratie anderzijds. 

Deel II

De moderatoren 


\section{Hoofdstuk 5}

\section{Individuele en psychologische factoren als moderatoren}

Als eerste groep van moderatoren bespreek ik in dit hoofdstuk de individuele factoren, met name de verblijfsvergunning. De andere twee individuele factoren die als moderatoren in het onderzoeksmodel zijn opgenomen, zijn geslacht en leeftijd. In onderzoeken 1 en 2 heb ik een onderscheid gemaakt tussen twee onderzoeksgroepen: asielzoekers (zonder een verblijfsvergunning) en (ex-)vluchtelingen (met een verblijfsvergunning). Bij onderzoek 3 is de soort verblijfsvergunning het belangrijkste criterium waarop de onderzoeksgroep in twee delen is verdeeld. Ik zal uitleggen waarom ik het onderscheid met betrekking tot het beschikken over een verblijfsvergunning belangrijk vind. Ik geef eerst beknopt een definitie van het woord 'moderator.' Vervolgens komen de soorten verblijfsvergunning en hun onderlinge verschillen aan de orde. Ik bespreek de rol van verblijfsvergunning als een stressfactor. Ik sluit dit hoofdstuk af met mijn betoog waarom ik het beschikken over een verblijfsvergunning als moderator heb onderzocht.

\subsection{Moderator en mediator: definities van twee begrippen}

Een moderator is een variabele die de richting en sterkte van de relatie tussen de onafhankelijke variabele (predictor) en de afhankelijke variabele (criterium) beïnvloedt. Bij een moderatiehypothese is de verwachting dat het effect van de predictor op het criterium niet rechtstreeks is, maar door een derde variabele (moderator) beïnvloed wordt. Een moderator kan kwalitatief (geslacht, klasse, ras) of kwantitatief (de mate van bekrachtiging, leeftijd) van aard zijn (Baron \& Kenny, 1986).

Van een mediator is er sprake als een variabele de relatie tussen de afhankelijke (criterium) en onafhankelijke variabele (predictor) verklaart.

Het verschil tussen moderator en mediator heeft vooral te maken met het soort van invloed. Een moderator oefent invloed uit op de relatie tussen de twee variabelen (modererend effect), terwijl een mediator invloeden van onafhankelijke variabelen opvangt en doorgeeft aan de afhankelijke variabele (mediërend effect). Een mediator helpt dus om een verklaring te geven voor de relatie tussen het criterium en de predictor (MacKinnon, 2008).

De functies van moderator en mediator kunnen we in drie niveaus verdelen: conceptueel niveau, strategisch niveau en statistisch niveau.

Een voorbeeld van moderatoreffect is het effect van controleerbare levensomstandigheden op de relatie tussen het gevoel van (on)welbevinden en life events. 
In een statistische analyse moet een differentieel effect van de predictor op het criterium gezien worden als het effect van de moderator. De wijze waarop het differentiële effect wordt gemeten, is afhankelijk van de niveaus van de meting van de onafhankelijke variabele en de moderatorvariabele.

\subsection{Verblijfsvergunning}

Mensen die hun eigen land ontvluchten wegens schending van hun mensenrechten, vrees voor eigen veiligheid en/of andere humanitaire redenen, kunnen in Nederland asiel aanvragen. Vluchtelingen kunnen voor een verblijfsvergunning in aanmerking komen op grond van de volgende redenen:

- Het Vluchtelingenverdrag van Genève en het Europees Verdrag tot Bescherming van de Rechten van de Mens.

- Klemmende redenen van humanitaire aard, bijvoorbeeld traumatische ervaringen.

- Als terugkeer naar het land van herkomst bijzonder moeilijk is wegens de algemene situatie in het land van herkomst, bijvoorbeeld wanneer er sprake is van oorlog.

Vreemdelingen kunnen een asielaanvraag indienen bij één van de drie aanmeldcentra van de IND. Na het eerste gesprek met de IND krijgt de asielzoeker binnen vijf werkdagen te horen of er een verder onderzoek nodig is of dat zijn verzoek kansloos is. Indien er meer onderzoek nodig is, wordt de asielaanvraag verder in behandeling genomen. Tijdens het onderzoek verblijft de asielzoeker in Nederland in een van de opvanglocaties van het Centraal Orgaan opvang asielzoekers (COA).

Met de invoering van de Vreemdelingenwet in april 2001 is het proces versimpeld. Er is nu één Verblijfsvergunning voor Asiel-Bepaalde Tijd (VVA-BT). Deze voorwaardelijke en tijdelijke verblijfsvergunning kan na vijf jaar worden omgezet in een Verblijfsvergunning voor Asiel-Onbepaalde Tijd (VVA-OT). Dit is een definitieve verblijfsvergunning. Na vijf jaar mogen de vergunninghouders de Nederlandse nationaliteit aanvragen.

In de Vreemdelingenwet 2000-2001 is er sprake van één type verblijfsvergunning voor alle asielzoekers die worden toegelaten. Statushouders mogen betaald werk verrichten en hebben recht op huisvesting, scholing en studiefinanciering. Ze hebben ook onder bepaalde voorwaarden recht op gezinshereniging.

Vóór de invoering van de Vreemdelingenwet in 2001 kwamen de asielzoekers in aanmerking voor een verblijfsvergunning op basis van politieke of humanitaire redenen. De statushouders vielen toen onder twee categorieën: de A-status (voor de politieke vluchtelingen) en de C-status (overige groepen).

De IND is de enige instantie die kan beslissen of iemand in aanmerking komt voor een verblijfsvergunning. De IND beoordeelt altijd eerst of iemand vluchteling is volgens het Vluchtelingenverdrag en gaat dan verder met de andere twee categorieën. VVA-BT kan gedurende drie jaar worden ingetrokken wanneer de situatie in het land van herkomst is 
verbeterd. Een vergunning die verleend is op basis van vluchtelingschap geeft de vluchteling meer uitzicht op permanent verblijf. Een vergunning die verleend is op grond van een algemeen beschermingsbeeld kan veel makkelijker worden ingetrokken.

In onderzoeken 1 en 2 is er een onderscheid gemaakt tussen de twee groepen op grond van twee categorieën: vluchtelingen met een verblijfsvergunning voor onbepaalde tijd en/of Nederlandse nationaliteit, en asielzoekers zonder een verblijfsvergunning.

De respondenten van onderzoek 3 beschikken allemaal over een verblijfsvergunning. Het onderscheid tussen de twee groepen in onderzoek 3 richt zich echter op de verschillen met betrekking tot de bepaalde en de onbepaalde tijd-vergunning. De groep respondenten met een bepaalde tijd-vergunning valt over het algemeen onder de pardonregeling.

\subsubsection{Pardonregeling}

Op 15 juni 2007 heeft de regering het generaal pardon ingesteld. Asielzoekers zonder verblijfsvergunning, die langer dan 6 jaar in Nederland woonden, konden hierdoor een vergunning krijgen om in Nederland te verblijven.

Om voor het generaal pardon in aanmerking te komen, moest een asielzoeker aan de volgende voorwaarden voldoen:

1. De asielzoeker heeft de eerste asielaanvraag ingediend vóór 1 april 2001.

2. De asielzoeker woont sinds 1 april 2001 in Nederland.

De IND verstrekte verblijfsvergunningen aan personen die aan de voorwaarden van het generaal pardon voldeden. Voor de overige pardonkandidaten moest door middel van een burgemeestersverklaring aangetoond worden dat zij in Nederland waren. De verklaring werd verstrekt, als voldoende aantoonbaar was dat de (pardon)kandidaat het gehele jaar 2006 in Nederland had verbleven.

Per 1 januari 2009 is de pardonregeling officieel beëindigd.

In onderzoek 3 zijn de twee groepen vluchtelingen met onbepaalde tijd-verblijfsvergunning en vluchtelingen met een bepaalde tijd-verblijfsvergunning (pardonregeling) met elkaar vergeleken wat betreft hun gezondheid en het gevoel van welbevinden. Dit betekent dat het effect van het soort verblijfsvergunning (bepaalde vs. onbepaalde tijd) op hun psychische gezondheid is onderzocht. In onderzoek 3 is de verblijfsvergunning niet in het onderzoek opgenomen als een moderator. Er is rechtstreeks een vergelijking gemaakt tussen de twee onderzoeksgroepen.

\subsection{Verblijfsvergunning als een stressor}

In onderzoek 1 en 2 is een onderscheid gemaakt tussen de groepen asielzoekers en (ex-) vluchtelingen. In de literatuur worden deze twee termen soms door elkaar gebruikt.

Een asielzoeker is iemand die aanspraak maakt op het vluchtelingenstatuut. Via de 
gangbare procedures wordt zijn asielvraag onderzocht. In feite is een asielzoeker een kandidaat-vluchteling (Ramaekers, 1995).

Een vluchteling is volgens de Conventie van Genève van 1951, elke persoon die uit gegronde vrees voor vervolging wegens zijn ras, geloof, nationaliteit, het behoren tot een sociale groep of zijn politieke overtuiging, zich buiten het land bevindt waarvan hij de nationaliteit bezit, en die de bescherming van dat land niet kan of, uit hoofde van bovenbedoelde vrees, niet wil inroepen, of die, indien hij geen nationaliteit bezit en verblijft buiten het land waar hij vroeger zijn gewone verblijfplaats had, daarheen niet kan of, uit hoofde van bovenbedoelde vrees, niet wil terugkeren (Ramaekers, 1995).

Over het algemeen verblijven asielzoekers in open opvangcentra of in particuliere woningen. In de literatuur wordt regelmatig verwezen naar de navolgende negatieve kenmerken die als stressoren het leven van asielzoekers negatief beïnvloeden. Allereerst is er de hygiëne. Uit de onderzoeken van De Jongh \& Van Ee (2002), De Jongh et al. (2004) blijkt dat asielzoekers het gebrek aan voldoende hygiëne als een stressor met een negatieve invloed op hun gezondheid ervaren.

Het gebrek aan privacy vormt een andere stressfactor. Asielzoekers ervaren het als negatief omdat er dicht bij elkaar wordt geleefd en er lange tijd dezelfde ruimte wordt gedeeld (De Vries, 2002; Kramer, 2003; Kramer \& Cense, 2004).

De derde stressfactor betreft veiligheid. Asielzoekers ervaren heel wat onveiligheid in de opvangcentra (De Vries, 2002; Laban, 2003; Laban et al. 2008; De Jongh et al., 2004). Vooral vrouwen, en met name jonge alleenstaande vrouwen, voelen zich onveilig vanwege seksuele intimidatie, geweldpleging en ongewenst gedrag van mannelijke lotgenoten.

Nog een stressfactor die door asielzoekers wordt ervaren heeft betrekking op het gebrek aan mogelijkheden voor een zinvolle dagbesteding (Lock, 2005; Orthel, 2004; Vanmarcke, 2005).

De volgende factor is het werkverbod. De resultaten van de onderzoeken van Kramer \& Cense (2004), Laban (2003) en Dupont et al. (2005) laten zien dat vooral de mannelijke asielzoekers het werkverbod als een belangrijke stressfactor ervaren.

Verder ervaren asielzoekers regels en voorschriften (Vanmarcke, 2005; Jansen et al., 2002; De Jongh et al., 2004), herhaaldelijke overplaatsingen (Orthel, 2004; Laban, 2003), weinig sociale contacten (Kramer, 2003; Meylemans, 2005), discriminerend of racistisch gedrag van de medebewoners en de medewerkers van de opvangcentra (Kramer \& Cense, 2004) en de toegankelijkheid tot medische diensten (Kramer \& Cense, 2004) als de stressfactoren die hun psychische en lichamelijke gezondheid in gevaar brengen.

De laatste stressfactor is de asielprocedure. Volgens De Vries (2002) en Van Eyken (2005) kan de onzekerheid over de asielprocedure tot een gevoel van hopeloosheid leiden. Bepalend voor de mate waarin men een factor als bedreigend ervaart, is de duur van de periode die men in een opvangcentrum verblijft (De Vries, 2002).

Uit diverse onderzoeken blijkt dat asielzoekers een hoger gemiddeld aantal psychische klachten vertonen dan de vluchtelingen mét een verblijfsvergunning (Van Horebeek, 2005; De Jongh \& Van Ee, 2002; Gerritsen et al., 2006, 2007; Toar et al., 2009). 
Silove \& Ekblad (2002) stellen dat uit een verscheidenheid van onderzoeken naar de determinanten van psychische stoornissen bij vluchtelingen twee consistente risicofactoren voorkomen, namelijk traumatische ervaringen in het verleden en postmigratie-stressfactoren. Deze factoren dragen bij aan het in stand houden en de toename van psychische klachten (Lindencrona et al., 2008). Ik heb eerder verwezen naar enkele stressfactoren gedurende de asielprocedure. De spanning en stress die gepaard gaan met de procedure en de onzekerheid over het verkrijgen van een legale status in Nederland kunnen tevens samenhangen met symptomen van depressie en angst (Schweitzer et al., 2006).

Samenvattend blijkt uit deze onderzoeken dat de postmigratiefactoren een negatief effect uitoefenen op de psychische gezondheid van vluchtelingen en asielzoekers. Daarnaast blijkt dat asielzoekers in hun dagelijks leven regelmatig te maken hebben met diverse stressfactoren. De onzekerheid over het verkrijgen van een verblijfsvergunning en/of (niet) beschikken over een verblijfsvergunning wordt door asielzoekers ervaren als een belangrijke stressbron.

\subsection{Verblijfsvergunning als moderator}

Vluchtelingen en asielzoekers worden blootgesteld aan diverse stressvolle factoren. Deze factoren kunnen het psychische welzijn van de vluchteling negatief beïnvloeden. Een lange asielprocedure heeft een negatieve impact op de algemene gezondheid en hangt daarnaast samen met een lage beoordeling van de kwaliteit van leven (Laban et al., 2008). Het niet beschikken over een verblijfsvergunning kan door het individu als een bron van stress ervaren worden (De Vries, 2002; Van Eyken, 2005).

In het onderzoeksmodel van onderzoek 1 heb ik in 'het bezit zijn van een verblijfsvergunning' beschouwd als een individueel gebonden factor die ook als moderator de relatie tussen ervaren begeleiding en perceptie van kansen kan beïnvloeden. Deze hypothese is enerzijds gebaseerd op de bovenstaande literatuurstudie, en leunt anderzijds op het stresscopingmodel van Lazarus \& Folkman (1984).

Het model beschrijft de relatie tussen de persoonlijke beoordeling (appraisal) van een stressvolle situatie, in samenhang met persoonlijke hulpbronnen en copingstrategie, uitmondend in de mate van persoonlijk welbevinden. Daarmee is een stressvolle situatie volgens het model geen directe reactie op een stressor (geen lineaire relatie tussen predictor en criterium), maar wordt deze relatie beïnvloed door de hulpbronnen en de mogelijkheden van de persoon om met de situatie om te gaan. Mijn hypothese over het beschikken over een verblijfsvergunning (stressfactor en moderator) is gebaseerd op het gedachtegoed van het stresscopingmodel. Dit houdt in dat wanneer iemand een situatie en/of een stressor als negatief beoordeelt en weinig gebruik kan maken van hulpbronnen, dit effect kan hebben op zijn/haar beoordeling van een situatie en zijn/haar persoonlijke mogelijkheden. 
Het stresscopingmodel vormt de basis voor mijn hypothese dat onzekerheid over het verkrijgen van een verblijfsvergunning (als een individuele variabele) en de drie psychologische variabelen (coping, de mate van psychopathologie en depressie) als moderatoren de relatie tussen ervaren begeleiding en kansperceptie van respondenten beïnvloeden. 


\section{Hoofdstuk 6}

\section{Depressie als moderator}

Migratie wordt in de vakliteratuur vaak beschreven als een stressfactor (Tseng, 2001). Het gevoel van hopeloosheid speelt hierbij een grote rol. Ingrijpende, stressvolle en oncontroleerbare situaties voor, tijdens en na de vlucht, de moeizame asielprocedures en acculturatiestress in het gastland kunnen tot depressie leiden. Door de meegemaakte trauma's in het land van herkomst, de postmigratiefactoren en het moeizame integratieproces ontwikkelen veel vluchtelingen de symptomen van depressie. Een groot deel van de buitenlandse cliënten van de GGZ bestaat, zoals algemeen bekend, uit asielzoekers en vluchtelingen.

In dit hoofdstuk wordt allereerst het begrip 'depressie' beschreven. Vervolgens sta ik stil bij de theoretische verklaringen van depressie. Ik bespreek de geestelijke gezondheid van vluchtelingen. Daarna passeren depressie onder vluchtelingen en een literatuurstudie de revue. Dit hoofdstuk sluit ik af met een korte beschrijving van de 'Beck Depression Inventory' en mijn conclusie over het effect van depressie als een moderator op de relatie tussen kansperceptie en begeleidingsfactoren.

\subsection{Depressie: definitie van het begrip}

Depressie hoort bij de groep van de zogenaamde stemmingsstoornissen en is wereldwijd een van de meest voorkomende psychische stoornissen.

Volgens de Wereld Gezondheidsorganisatie hebben over de hele wereld zo'n 340 miljoen mensen last van depressie en zal dit aantal alleen maar toenemen. In Nederland hebben 600.000 mensen last van depressieve klachten. Bij een groot deel van die mensen wordt de ziekte niet herkend. ledereen krijgt wel eens te maken met een gevoel van somberheid, maar er bestaat verschil tussen somberheid en gewone neerslachtigheid enerzijds, en depressie anderzijds.

Meer dan twintig procent van de bevolking maakt in de loop van het leven een depressie door (Kessler et al., 2003). Depressieve stoornissen zijn de meest behandelde aandoeningen in de ambulante geestelijke gezondheidszorg (Cuijpers et al., 2008).

Depressie beïnvloedt het functioneren van mensen op diverse levensgebieden. De diagnose van depressie wordt gesteld als iemand gedurende ten minste twee weken minstens één van de volgende twee kernsymptomen heeft:

- ernstige somberheid/neerslachtigheid die gedurende het grootste deel van de dag en bijna iedere dag aanwezig is;

- een ernstig verlies van interesse in alle of bijna alle activiteiten gedurende het grootste deel van de dag of bijna iedere dag. 
Behalve deze twee kernsymptomen dienen nog andere symptomen aanwezig te zijn:

- rusteloosheid of zich geremd voelen;

- vermoeidheid en verlies van energie;

- slaapproblemen (moeite met in- en/of doorslapen); dit noemt men insomnia;

- schuldgevoel of zich waardeloos voelen;

- concentratieproblemen of afgenomen vermogen tot nadenken, besluiteloosheid;

- duidelijke gewichtstoename of -verlies zonder dat een dieet gevolgd is;

- afnemen van libido;

- terugkerende gedachte over de dood of zelfdoding.

Depressie kent verschillende gradaties. Er is sprake van depressie in engere zin als vijf van de bovengenoemde symptomen aanwezig zijn, inclusief neerslachtigheid en/of interesseverlies (anhedonia). Soms gaat depressie gepaard met allerlei andere klachten, zoals paniek en angstgevoelens, prikkelbaarheid, snelle irritatie, veel of juist niet kunnen huilen en diverse lichamelijke klachten zonder duidelijke oorzaken.

Bij het ontstaan van depressieve stoornissen spelen onder andere de genetische, de omgevings- en de persoonlijkheidsfactoren een rol. Bij omgevingsfactoren spelen de gevolgen van negatieve levensgebeurtenissen (life events) een belangrijke rol, zowel in de vroege jeugd als in het meer recente verleden. Ook kunnen lichamelijke factoren zoals bepaalde lichamelijke ziekten, het gebruik van geneesmiddelen, alcohol en drugs het ontstaan van depressie beïnvloeden. Het onderscheid tussen etiologische en pathologische factoren is dat een etiologische factor alleen invloed kan hebben als er ook een pathologisch mechanisme aanwezig is.

\subsection{Theoretische verklaring}

De cognitieve theorie van Beck gaat ervan uit dat bepaalde 'disfunctionele' of 'automatische cognities' als intermediair werken tussen gebeurtenissen of situaties. Het ervaren van deze disfunctionele gedachten is bepalend voor depressieve of angstige gevoelens (Beck et al., 1979).

Beck et al. (1979) kwamen op basis van hun klinische ervaringen met patiënten tot de conclusie dat de patiënten regelmatig bezig zijn met negatieve gedachten over zichzelf, hun omgeving en hun toekomst. Hij benadrukte het belang van cognitieve functies niet alleen in verband met de etiologie van depressie, maar ook in verband met de behandeling van depressie. Bij depressie hebben de cognities vooral betrekking op de persoon zelf, zijn omgeving en de toekomst. Ze zijn disfunctioneel als ze tot ongewenste gevoelens leiden. Volgens Beck en zijn collega's wordt de informatieverwerking bij depressieve mensen beheerst door interpretaties en verwachtingen van verlies. Hierdoor zouden de sombere stemming en het gebrek aan motivatie tot stand komen.

Een andere belangrijke benadering over depressie komt uit de hoek van stressmodellen 
en de life-eventsbenadering. De theorie van life events ziet de oorzaak van depressie voornamelijk in de externe factoren. De rol van de stressvolle gebeurtenissen wordt daarbij vooral benadrukt. Langdurige spanningsvolle omstandigheden en ingrijpende gebeurtenissen werken depressieve symptomen in de hand. Uit de grote groep studies blijkt dat stressvolle, oncontroleerbare en ontwrichtende gebeurtenissen de risicofactoren zijn bij de aanvang en terugkeer van depressie (Shrout et al., 1989; Bruce et al., 1991; Flynn, 1993). De sociale-netwerktheorie en de sociale-supporttheorie gaan ervan uit dat depressieve mensen weinig sociale ondersteuning krijgen en een klein sociaal netwerk hebben of dat hun sociale ondersteunende netwerken te ver weg wonen. Depressieve mensen rapporteren dat ze weinig hulpvolle contacten hebben. Ze beschouwen hun interpersoonlijke contacten als niet en/of niet genoeg ondersteunend. Ten slotte blijkt uit verschillende studies dat depressieve mensen het contact met het sociale netwerk als problematisch ervaren.

Sociaal isolement, gebrekkige of weinig sociale ondersteuning, verlies en werkloosheid kunnen tot depressie leiden, maar ook de fysieke omgeving, zoals armoede, slechte behuizing en gebrek aan welstand. Volgens de life-eventstheorie leiden de levensomstandigheden niet tot depressieve stoornissen. Het zijn de interacties tussen fysieke en sociale omstandigheden en de persoonlijkheidskenmerken die tot depressie kunnen leiden. Volgens deze opvatting creëren spanning en stress een soort kwetsbaarheid voor depressie.

Deze studie gaat ervan uit dat bij het ontstaan van depressie een combinatie van cognitie (persoonsgebonden factor) en de spanningsvolle situaties (omgevingsgebonden factor) van belang is. Zowel de wijze waarop ieder persoon zijn situatie interpreteert en daarmee omgaat als langdurige stressvolle situaties hebben effect op het tot stand komen van depressie.

\subsection{Gezondheid van asielzoekers en vluchtelingen}

Wat men onder gezondheid verstaat, verschilt tussen individuen, culturele groepen en de sociale klassen. In de definitie van WHO van 1946 wordt gezondheid beschreven als een vorm van welbevinden. Welbevinden is een subjectieve maat om gezondheid te meten. Volgens deze definitie staat de beleving van gezondheid of 'zich gezond voelen' los van de medische status van gezondheid of ziek zijn. Gezondheid behelst een toestand van volledig lichamelijk, geestelijk en sociaal welzijn en niet slechts de afwezigheid van ziekte of gebrek.

In veel niet-geïndustrialiseerde landen wordt gezondheid ervaren als een gebalanceerde relatie tussen mens en natuur, én tussen de mens en de bovennatuurlijke wereld (Helman, 1990). De term gezondheid wordt vaak gebruikt om aan te duiden dat men niet ziek is en niet aan een (lichamelijke) ziekte lijdt. Leken definiëren gezondheid anders dan mensen met een medisch beroep. Jozefzoon (1999) heeft een onderzoek verricht naar de gezondheidsbeleving van asielzoekers. Het onderzoek had ten doel om naast het beschrijven van de ervaren gezondheid na te gaan of er samenhang bestaat tussen gezondheids- 
beleving en de aspecten van de asielprocedure. Uit onderzoek blijkt dat asielzoekers hun gezondheid als slechter ervaren dan elke andere groep in de Nederlandse samenleving. Niet alleen de Nederlanders, maar ook andere allochtone groeperingen beleven hun gezondheid positiever dan asielzoekers. Angst, posttraumatische stressstoornis en depressie zijn de voornaamste klachten van asielzoekers. Ook Hondius \& Van Willigen (1992) concluderen dat vluchtelingen en asielzoekers over het algemeen veel aspecifieke lichamelijke en psychische klachten én sociale problemen hebben. Met aspecifiek wordt bedoeld dat klachten geen duidelijke aanwijzing geven voor een bepaald ziektebeeld. De aard van de lichamelijke klachten betreft vooral hoofdpijn, gastro-intestinale klachten, musculoskeletale klachten, angst en depressie. Onderzoek van De Jongh \& Van Ee (2002); Laban (2008) en Toar et al., (2009) bevestigt de bevindingen van bovenstaande auteurs. Asielzoekers ervaren hun gezondheidstoestand als nog slechter vergeleken met vluchtelingen. Dit bevestigt de indruk dat de asielprocedure veel spanning en stress teweeg kan brengen.

Een bijzondere vorm van stress waar migranten en vooral de groep vluchtelingen mee te maken krijgt, wordt acculturatiestress genoemd. Migranten doorlopen de acculturatie op verschillende manieren. Sommigen sluiten het proces succesvol af, bij anderen treden stagnaties op. Uit de studie van Laban et al. onder asielzoekers in Nederland blijkt dat langdurige asielprocedures tot meer psychopathologieklachten en negatieve beleving van psychisch welbevinden leiden (Laban et al., 2008).

Berry et al. (1992) noemen als oorzaak van acculturatiestress een aantal factoren. Deze factoren kunnen we verdelen in twee grote groepen: de omgevings- en de individuele factoren. Hij onderscheidt verder de volgende factoren:

- de wijze van acculturatie (integratie, assimilatie, separatie, marginalisatie);

- de fase van acculturatie;

- de aard van de ontvangende samenleving (multicultureel of gericht op assimilatie);

- al dan niet aanwezigheid van vooroordeel, xenofobie en discriminatie;

- groepskenmerken (leeftijd, status, sociale steun);

- individuele kenmerken (copingstijl, gedrag, waardering, attitude en contact).

Kenmerken als complexiteit en de duur van de procedure, de opvang en huisvesting én de beperkingen waarmee asielzoekers te maken hebben, zouden van invloed kunnen zijn op hun negatieve gezondheidsbeleving.

In de literatuur worden verschillende factoren aangegeven als oorzaken van gezondheidsklachten bij asielzoekers en vluchtelingen. Vluchtelingen relateren hun lichamelijke en psychische klachten aan het ondergaan van vormen van 'organized violence' en aan onderdelen van hun leven als vluchteling in een gastland. Vluchtelingen leggen een link tussen hun klachten en hun sociale positie aan de ene kant, en het acculturatieproces aan de andere kant (Hondius \& Van Willigen 1992; De Jongh \& Van Ee, 2002). Asielzoekers hebben vooral het gevoel dat ze geen invloed kunnen uitoefenen op hun eigen lot. Een afhankelijke positie brengt bij deze groep het gevoel van hopeloosheid teweeg. Depressie en posttraumatische stressstoornis zijn de meest voorkomende klachten bij vluchtelingen. 
Volgens Knipscheer \& Kleber (1998, 2004a, 2005, 2005b) is het zeer belangrijk dat naast de factoren 'cultuur en migratie', ook het concept acculturatie betrokken wordt bij de gezondheidsanalyse van migranten en vluchtelingen. Acculturatie hoeft niet noodzakelijkerwijs te leiden tot negatieve consequenties. Studies naar de relaties tussen gezondheid en acculturatie laten dan ook uitlopende resultaten zien (Van Oudenhoven et al., 1998; Mooren et al., 2003; Knipscheer \& Kleber, 2006). Toch leggen deze studies een link tussen sommige dimensies van acculturatie en de ervaren psychische gezondheid. Ook demografische factoren houden hiermee verband. Onderzoek van Blair (2000) liet een sterke samenhang zien tussen actuele stressfactoren en depressie. Uit onderzoek van Gerritsen et al. $(2005,2006)$ is gebleken dat de algemene gezondheid van asielzoekers slechter is dan die van de autochtone Nederlandse bevolking.

Silove et al. (2000) concluderen op basis van hun studie dat de postmigratiestress van asielzoekers het behandelen van depressieve klachten nog moeilijker maakt. Uit onderzoeken van Bhugra (2004), Knipscheer et al. (2004c) en Komproe (2002) blijkt dat de veranderingen en verliezen die migranten en vluchtelingen meemaken, doorgaans de kwetsbaarheid voor de ontwikkeling van gezondheidsproblemen, met name depressie, vergroten.

Carlsson et al. (2006) hebben de psychische gezondheid van vluchtelingen onderzocht die langer dan tien jaar in het gastland woonachtig waren. Ze zien een duidelijk verband tussen de indicatoren van kwaliteit van leven van vluchtelingen, zoals werken en sociale steun, en de mate van ervaren van psychische gezondheid, PTSS en depressie. Werken en sociale steun hebben een bufferfunctie.

Uit het onderzoek van Gerritsen et al. (2006) dat onder Iraanse, Afghaanse en Somalische asielzoekers en vluchtelingen heeft plaatsgevonden, blijkt dat de helft van de respondenten in hoge mate last heeft van diverse psychopathologische klachten. Daarnaast blijkt uit hun onderzoek dat Iraniërs meer klachten vermelden dan de andere twee groepen. Hogere leeftijd en meer life events hebben positieve verbanden met de psychopathologische klachten. Kraus \& Zavalkink (2009) vergeleken de resultaten van het klachtenpatroon van niet-westerse allochtonen en autochtone patiënten op de SCL-90-Rvragenlijst en een Interpersoonlijke Vragenlijst (IIP-64). Uit hun studie bleek dat de scores van allochtone patiënten op de SCL-90-R ongedifferentieerd hoog waren in vergelijking met de scores van autochtone patiënten.

\subsection{Depressie bij vluchtelingen}

Vluchtelingen worden onvermijdelijk geconfronteerd met andere culturele opvattingen. Deze confrontaties zijn een belangrijke bron van spanning en dit kan ertoe leiden dat vluchtelingen psychisch gevoeliger en kwetsbaarder zijn, en eerder depressief worden dan de gewone populatie. 
Het proces van aanpassing en integratie is een langdurige en stressvolle aangelegenheid. Dit proces kan ertoe leiden dat de vluchteling in een depressieve stemming terechtkomt. De mate van depressie heeft naar mijn mening daarmee invloed op de wijze waarop vluchtelingen hun kansen in Nederland waarnemen.

Gernaat et al. (2002) vonden bij Afghaanse vluchtelingen met een verblijfsstatus bij $57 \%$ van de individuen depressie en bij $35 \%$ een posttraumatische stressstoornis. Van Ommeren et al. (2002) constateerden dat $84 \%$ van gemartelde vluchtelingen onverklaarde lichamelijke klachten had.

Uit verschillende studies blijkt dat vluchtelingen gedurende de acculturatieperiode onderhevig zijn aan diverse psychische stoornissen. Vluchtelingen vormen een risicogroep in de gezondheidszorg (Nguyen, 1989; Allodi, 1991; Williams \& Berry, 1991; Hondius \& Van Willigen, 1992; Van der Pol, 1995; Van der Veer, 1991; Nekuee \& Verkuyten, 1999; Pernice \& Brook, 1996; Keyes, 2000; Bauer \& Priebe, 1994; Vera, 1998). Bovendien blijkt uit vele epidemiologische studies dat bij vluchtelingen en migranten een groot percentage depressie, angst en posttraumatische symptomen voorkomt (Mghir et al., 1995; Boyd, 1998; Beiser \& Hyman, 1997; Van Willigen et al., 1995; Silove et al., 2000, 2007; Bean et al., 2006; Heptinstall et al., 2004; Thabet et al., 2004). Uit studie van Oostrum et al. (2011) blijkt dat de mate van 'suïcidaliteit en suïcidepogingen' onder asielzoekers hoger is dan onder de normale Nederlandse populatie. Toar et al. (2009) concluderen op basis van hun vergelijkende studie tussen asielzoekers en vluchtelingen in West-Europa dat asielzoekers over het algemeen meer psychopathologische klachten rapporteren dan vluchtelingen.

Vooral depressie is een bekende psychische stoornis die onder vluchtelingen vaak voorkomt (Murphy, 1965; Lin et al., 1985; Carlson \& Rosser-Hogan, 1991; Bauer \& Priebe, 1994; Mghir et al., 1995; Aziz, 1999; Hsu, 1999). Barnes (2001) en Chan Won Shing (2001) komen in hun onderzoek tot de conclusie dat vluchtelingen een risicogroep vormen voor depressie, angst en PTSS. Keyes (2000) concludeert op basis van haar studie dat er bij de groep vluchtelingen sprake is van een hoge mate van psychopathologie vergeleken met de gewone populatie. Volgens Carlsson et al. (2006) blijft het niveau van emotionele kwetsbaarheid na tien jaar behandeling bij de groep vluchtelingen hoger dan bij de gewone populatie.

Bij de groep adolescenten en volwassen vluchtelingen is een hoge mate van depressie en PTSS geconstateerd (Thabet et al., 2004; Bean et al., 2007a; Silove et al., 2007). Uit een grootschalig gezondheidsonderzoek onder asielzoekers door het VU medisch centrum in 2003-2004, blijkt dat asielzoekers over het algemeen meer psychische en gezondheidsklachten rapporteren dan vluchtelingen. Asielzoekers hebben over het algemeen meer angst- en depressieve klachten (68 tegen 39\%). Uit het onderzoek blijkt verder dat Iraniërs veel angst- en depressieve klachten rapporteren. 76\% van de Iraniërs die aan het onderzoek hebben meegedaan, beschrijft hun gezondheid als matig/slecht. Ook hebben Iraniers meer psychische klachten (voornamelijk depressie en posttraumatische symptomen). 
Bij de Joegoslavische vluchtelingen leiden gezondheidsklachten, en vooral depressie en PTSS tot het minder kunnen profiteren van acculturatiecursussen en trainingen (Silove et al., 2005). In de studies van Mollica et al. $(1992,2001)$ en Momartin et al. (2004) wordt de comorbiditeit tussen depressie en PTSS benadrukt. Momartin et al. (2004) zijn van mening dat een chronische depressie tot meer sociale handicaps leidt dan PTSS.

Depressieve klachten van Aziatische vluchtelingen doen zich vooral voor in de vorm van somatische stoornissen. Hieraan zouden dan cultuurgebonden factoren ten grondslag liggen (Hsu, 1999; Westermeyer et al., 1989; Morris \& Silove, 1992). Uit diverse studies blijkt dat langdurige, stressvolle situaties negatieve effecten hebben op het psychische welbevinden en op de ervaren sociale integratie van de vluchtelingen en migranten (Kleber et al., 1995; Weine et al., 1998; Mghir et al., 1995).

Diverse wetenschappelijke studies laten zien dat er een hoge comorbiditeit bestaat tussen depressie en PTSS (Breslau et al., 2000; Bargai et al., 2007; Basoglu et al., 2004; Ginzburg, 2006). Volgens Momartin et al. (2004) zijn levensbedreigende situaties gerelateerd aan PTSS, terwijl levensbedreiging en verlies samen geassocieerd zijn met de comorbiditeit van PTSS en depressie. De groep met comorbide klachten toont meer en ernstigere PTSS-klachten evenals hogere niveaus van beperkingen op globaal, sociaal en beroepsmatig functioneren (Momartin et al., 2004). Depressie kan ook een reactie zijn op PTSS of er kan sprake zijn van een overlap van klachten (Thabet et al., 2004). Cognitieve factoren zoals negatieve cognities over zichzelf en zelfverwijt, gemeten met de Beck Depression Inventory, lijken geassocieerd met de instandhouding van PTSS (Feeny et al., 2000). Aanwezigheid van depressie bij traumaslachtoffers is een belangrijke voorspeller voor niveaus van gerapporteerde PTSS-klachten na behandeling (Blanchard et al., 2003).

Rudmin en Ahmadzadeh (2001) hebben in hun studie onder Iraanse vluchtelingen in Noorwegen geen verband gevonden tussen acculturatieaspecten en psychische klachten. In tegenstelling tot Rudmin en Ahmadzadeh komen Gerritsen et al. (2006) tot de conclusie dat depressieve, PTSS- en angstklachten van Iraanse vluchtelingen wel degelijk met acculturatie- en postmigratiefactoren te maken hebben. Verder blijkt uit hun studie dat de mate van depressie en PTSS-klachten onder Iraanse vluchtelingen en asielzoekers hoger is dan bij Afghaanse en Somalische asielzoekers. Life events en postmigratiefactoren werken depressieve klachten in de hand. De resultaten van de studie van Gerritsen et al. (2006) geven een pessimistisch beeld van de gezondheidssituatie en het gevoel van welbevinden van Iraanse vluchtelingen vergeleken met de studie van Van den Tillaart die in 2000 heeft plaatsgevonden. Uit andere studies die al eerder onder Iraanse vluchtelingen hebben plaatsgevonden, blijkt dat Iraanse vluchtelingen hun depressie op dezelfde manier beschrijven als Nederlanders (Good et al., 1985; Van der Veer, 1987; Richters, 1991; Marrewijk, 1997; Priebe \& Esmaili, 1998).

\subsubsection{De BDI: Depressie-vragenlijst van Beck}

De BDI bestaat uit 21 vierkeuzevragen die zijn samengesteld op basis van uitspraken van depressieve patiënten. De vragenlijst is bedoeld voor de meting van depressie. De lijst 
bevat één schaal en kent een volledige ( 21 items) en een verkorte (13 items) versie. De psychometrische kwaliteit van de vragenlijst is redelijk. De lijst bestaat uit de volgende aspecten: somberheid, pessimisme, het gevoel van mislukking, ontevredenheid, schuld, ergens voor gestraft worden, niet van zichzelf houden, zichzelf beschuldigen, suïcidale ideeën, huilen, prikkelbaarheid, sociaal isolement, beslissingen nemen, het oordeel over persoonlijk uiterlijk, achteruitgaan op het werk, slapeloosheid, vermoeidheid, anorexia, gewichtsverlies, zich zorgen maken over gezondheid, libido (seksuele belangstelling).

In onderzoek 1 heb ik de volledige versie met 21 items gebruikt. De BDI wordt ook in Iran gebruikt, zowel ten behoeve van wetenschappelijke onderzoeken als in de klinische praktijk.

\section{Conclusie:}

Samenvattend blijkt uit diverse studies dat vluchtelingen en asielzoekers vanwege hun voorgeschiedenis (life events, de meegemaakte trauma's en verlieservaringen) en de postmigratiefactoren een kwetsbare groep vormen met betrekking tot het ontwikkelen van diverse psychische klachten en in het bijzonder depressieve klachten. Verder blijkt uit sommige studies dat de acculturatiestress een voorspeller is voor het ontwikkelen van depressie. In mijn studie is het effect van acculturatiefactoren op de mate van depressie niet onderzocht.

Eén hypothese van dit onderzoek is dat depressie een modererend effect heeft op de relatie tussen de begeleidingsfactoren en de perceptie van kansen. Deze hypothese is gebaseerd op de literatuurstudie op het gebied van depressie onder vluchtelingen en migranten enerzijds, en de relatie tussen life events, traumatische ervaringen en depressieve klachten anderzijds. Ik verwacht (statistisch gezien) dat de respondenten die op de depressie-vragenlijst hoog scoren, negatiever staan ten opzichte van hun integratiekansen, zelfs als ze tevreden zijn over de ontvangen begeleiding. Met andere woorden: de verwachting is dat de positieve relatie tussen tevredenheid over de begeleiding en kansperceptie minder sterk is wanneer de depressiescore hoog is. Depressie verhindert als het ware om te profiteren van de positieve effecten van een goede begeleiding. Daarom is in onderzoek 1 het effect van depressie als een moderator onderzocht. 


\section{Hoofdstuk 7}

\section{Copingstijl als moderator}

Coping wordt beschreven als de manier waarop mensen zowel cognitief als gedragsmatig als emotioneel op problematische gebeurtenissen reageren. Coping wordt vaak gezien als een persoonlijkheidskenmerk. Coping speelt een belangrijke rol bij het aanpassingsproces na ervaring van life events en psychologische trauma's waarbij de traumatische ervaring zelf een ondergeschikte rol heeft. Daarnaast blijkt dat copingstijl gerelateerd is aan depressieve klachten. De wijze waarop mensen een taxatie maken van moeilijke situaties en daarmee omgaan, is per persoon anders en is een belangrijke factor bij het ervaren van psychisch (on)welbevinden. In deze studie onderzoek $i k$ het modererende effect van copingstijl op de relatie tussen de begeleidingsvariabelen en de kansperceptie van de respondenten.

Ik breng eerst het begrip coping vanuit verschillende benaderingen in beeld. Vervolgens komen aan de orde: de relatie tussen stress en coping, cultuur en coping en de copingstijl van vluchtelingen. Daarna bespreek ik het effect van copingstijl op de wijze waarop de begeleiding naar integratie ervaren wordt. Ten slotte geef ik een korte beschrijving van de UCL, de copingvragenlijst die ik in deze studie heb gebruikt.

\subsection{Coping als begrip}

Het woord coping komt oorspronkelijk uit de sociale psychologie. Copingstijl wordt gedefinieerd als de manier waarop mensen omgaan met problemen of een problematische situatie die aanpassing vereist. Coping is zowel gericht op directe actie als op het reguleren van emoties. Ridder et al. (2004) definiëren coping als het in gang zetten van een bepaald scenario van cognitieve of gedragsmatige inspanningen dat erop gericht is de spanning die de dreigende of ambigue stimulus oproept, hanteerbaar te maken.

Lazarus (1966) verwees naar twee soorten copingstijlen: probleemgerichte en emotiegerichte copingstijlen. Coping wordt omschreven als gedachten en handelingen die mensen gebruiken om te kunnen omgaan met interne en externe eisen van stressvolle gebeurtenissen (Folkman \& Lazarus, 1980). Coping heeft twee functies: het oplossen van de problemen en het reguleren van de beangstigende emoties. De eerste functie van coping heeft te maken met 'controle krijgen en/of het oplossen van problemen'. Deze vorm van coping is beschreven als oplossingsgericht. De tweede functie van coping heeft te maken met de regulerende functie van coping die vooral emotiegericht is. De twee soorten copingstijlen kunnen als volgt worden samengevat: 
A. Probleemgerichte coping: in probleemgerichte copingstijl probeert men de oorzaak van stress direct aan te pakken en op te lossen. Deze coping richt zich op problemen die stress veroorzaken en houdt in het zoeken naar informatie over de stressor, het maken van een actief plan, het zich concentreren op de volgende te nemen stap om het probleem op te lossen (Folkman \& Moskowitz, 2004).

B. Emotiegerichte coping: men reguleert emotionele reacties om met situaties om te gaan, bijvoorbeeld door afleiding te zoeken, zich te ontspannen en/of emotionele steun te zoeken bij anderen. Men verricht geen directe acties, maar probeert de stressoren te vermijden of er afstand van te nemen (Wagenvoort et al., 1998). Palliatieve (afleiding zoeken), vermijdende en afwachtende reacties zijn een paar voorbeelden van emotiegerichte copingstijlen. Een emotiegerichte copingstijl richt zich op het hanteren van emotionele stress geassocieerd met de stressor.

Een veelvoorkomend idee over copingstijl is dat mensen over het algemeen dezelfde copingstijl hanteren als ze problemen tegenkomen. Dit betekent nog niet dat coping statisch van aard is en/of een statische werking heeft. Copingstijlen zijn dynamisch en passen zich aan de gebeurtenissen aan. Beide vormen van coping worden gebruikt in bijna alle stressvolle situaties.

Lazarus \& Folkman (1984) beschrijven coping als constant veranderende cognitieve en gedragsmatige pogingen om specifieke externe en/of interne eisen te hanteren, die geschat worden als belastend of grensoverschrijdend voor de individuele aanwezige mogelijkheden.

Volgens Lazarus zijn vrijwel alle ideeën over de effecten van coping en sociale steun gebaseerd op het 'stress respons axioma'. Dit axioma stelt dat sociale steun en coping de impact van de stressor (ervaren gebeurtenis) op de respons (mentale gezondheid) beïnvloeden.

Welke vorm van coping het meest effectief is, verschilt van situatie tot situatie. Op de lange termijn blijkt een directe, actieve en oplossingsgerichte copingstijl de beste stijl te zijn, indien de oorzaken van stressoren extern en controleerbaar zijn. Wanneer de oorzaken echter niet onder de controle van het individu vallen, is een oplossingsgerichte strategie per definitie onmogelijk. In dit soort gevallen zullen er meer emotiegerichte copingstijlen gebruikt worden die doorgaans op korte termijn resultaat hebben.

De interpretatie van de situatie, het oordeel dat iemand velt over de situatie en de persoonlijke kracht van het individu bepalen welke copingstijl iemand gebruikt. Lazarus brengt copingstijl in verband met de cognitieve beleving van stress en/of trauma. Bij het hanteren van copingstijl speelt het cognitieve vermogen een belangrijke rol. Met cognitief vermogen bedoel ik de kennis en de geheugenprestaties en operationaliseringvermogens van intelligentie, zoals praktisch probleemoplossend vermogen enerzijds en de sociale competentie anderzijds.

Lazarus spreekt van secundaire coping wanneer het niet zozeer om een gegeven situatie gaat, als wel om het hanteren van de daaruit voortvloeiende emoties. Er is volgens hem 
een verband tussen de cognitieve beleving van stress en trauma en zich buiten de situatie stellen enerzijds, en hopeloosheid en de zaak ontkennen anderzijds.

Folkman \& Lazarus (1980) beschrijven twee vormen van probleemgerichte copingstijlen: cognitieve en gedragsmatige strategieën. Men gebruikt de gedragsmatige strategie om de situatie te veranderen. Planning en positief herinterpreteren van de situatie worden beschreven als cognitieve probleemgerichte copingstijlen, waarbij men leert om met de situatie om te gaan in plaats van die te veranderen (De Vries \& Van der Werve, 1999).

Grofweg zien we in de literatuur twee benaderingen van het begrip coping. In de eerste benadering wordt coping gedefinieerd als een redelijk stabiel persoonlijkheidskenmerk. In dit geval wordt doorgaans de term copingstijl gebruikt. Vanuit de tweede benadering wordt het interactieproces tussen de persoon en zijn omgeving benadrukt. Coping wordt in dit geval voor een groot deel bepaald door de situatie. De invloed van deze situationele factoren op de taxatie van de situatie door de persoon is in deze benadering vooral belangrijk.

\subsection{Relatie tussen stress en coping}

In de studies van Richard Lazarus is de betekenis die de persoon zelf aan de situatie toeschrijft, bepalend voor de eventuele stressreactie. Mensen beoordelen de situatie onder bepaalde omstandigheden en ze beschouwen de situatie als (niet) gevaarlijk en (niet) bedreigend. De schatting die mensen van de situatie maken, de doelen die zij zichzelf stellen en hun aspiratieniveau zijn bepalend bij het hanteren van hun copingstijl. Volgens Lazarus is coping afhankelijk van twee factoren: het oordeel dat iemand velt over de situatie, en de kracht en de eigen mogelijkheden waarover iemand beschikt om de situatie onder ogen te zien en te beïnvloeden.

Lazarus plaatst twee interveniërende processen tussen de stressor en de uiteindelijke stressreactie: de subjectieve inschatting van de situatie en de eigen mogelijkheden van de persoon.

Copingstijl wordt beschouwd als een belangrijke component bij het omgaan met stress. Coping is een individueel proces dat gebruikt wordt om negatieve aspecten van de omgeving te nuanceren en de interne dreiging door stress te minimaliseren. In de literatuur wordt benadrukt dat er individuele verschillen tussen mensen bestaan met betrekking tot hun coping en de wijze waarop ze met stress omgaan. Coping wordt gezien als een mediator tussen de specifieke, stressvolle life events en de daaraan verbonden emotionele en fysiologische response. Copingstijlen zijn vanuit dit perspectief benaderd als zowel gedragsactiviteiten als cognitieve activiteiten.

In het model van Lazarus \& Folkman (1984) staat cognitieve appraisal centraal. Cognitieve appraisal omvat drie 'appraisal (taxatie)-processen': primary, secondary en reappraisal.

'Appraisal' (taxatie) wordt beschreven als de wijze waarop mensen de situaties inschatten. Van iedere stimulus wordt een schatting gemaakt van zijn bedreiging. 
- Primary appraisal betreft de taxaties die mensen maken van de significante aspecten van de situaties, zoals stressvol, positief, controleerbaar, uitdagend of (niet) relevant.

- Secondary appraisal heeft betrekking op de taxaties die mensen maken van de mogelijkheden die ze tot hun beschikking hebben om de situaties te veranderen.

- Mensen maken ook een herevaluatie van de situatie (reappraisal). Ze gaan op zoek naar de alternatieve interpretatie van de emotionele stimulus zodat die minder gevaarlijk of negatief waargenomen en geïnterpreteerd wordt.

Het 'appraisal-model' van coping heeft een psychologisch karakter. Het model gaat ervan uit dat stress een psychologische toestand is: een intern beeld van problemen dat gestalte krijgt door de interactie tussen de persoon en zijn omgeving. De uitkomst van een stressvolle interactie wordt gemedieerd door appraisal en coping. Daarnaast hebben individuele verschillen hun eigen invloed op de beide aspecten. Ferguson \& Cox (1991) concluderen op basis van hun studie dat 'primary appraisal' vooral verband houdt met het stressvolle karakter van de situatie, terwijl 'secondary appraisal' meer verband houdt met de persoon en het nemen van beslissingen.

Ik ben ervan uitgegaan dat copingstijl een individuele reactie is op stressvolle situaties. De reactie komt tot stand door interactie tussen de persoon en zijn omgeving. Hoe vluchtelingen stressvolle situaties in eerste instantie waarnemen, interpreteren en vervolgens taxeren (primary en secondary appraisal), heeft naar mijn mening invloed op de wijze waarop ze met de stressvolle situaties omgaan.

\subsection{Copingstijl en cultuur}

Triandis (1989) brengt culturele oriëntaties in verband met copingstijl. Zij verwijst naar twee copingstijlen: individualistische en op zichzelf gerichte copingstijlen die in westerse landen gebruikt en beloond worden, en collectief en sociaal georiënteerde copingstijlen in Azië en in Latijnse landen. Westerse landen bevorderen individualistische doelen en zelfvertrouwen, terwijl in de collectief ingerichte samenlevingen gestreefd wordt naar centrale groepsdoelen (Falicov, 1982; Bernal, 1982; Shon \& Ja, 1982; Wheeler et al., 1989). Ook Markus \& Kitayama (1991) benadrukten het verschil tussen de westerse en de oosterse culturen. Onafhankelijke copingstijl is het meest gericht op zelfvertrouwen en het minst op sociale steun. 'Interdependence coping' is het meest gericht op de interpersoonlijke relaties en brengt harmonieuze verhoudingen teweeg. Hoewel in de westerse wereld het actief wegnemen van een stressor het meest aanspreekt als de ideale manier van coping, kan deze stijl ook in veel gevallen een onverstandige aanpak zijn. Hoewel coping een culturele inkleuring heeft, kunnen we niet beweren dat mensen in sommige culturen gemakkelijker met extreme en/of problematische situaties omgaan dan mensen uit andere culturen. 
In deze studie beperk ik me tot twee algemene copingstijlen, namelijk de probleemgerichte en de emotiegerichte copingstijl. De relatie tussen de cultuur en copingstijlen wordt in deze studie niet verder onderzocht.

\subsection{Copingstijl van vluchtelingen}

Al sinds lange tijd bestaat er grote interesse voor de relatie tussen coping en psychische en lichamelijke gezondheid bij diverse bevolkingsgroepen en populaties. In de literatuur bestaan diverse studies over de copingstijl van vluchtelingen.

Baker (1992) beschrijft de copingstijlen van vluchtelingen in Europa die met geweld en marteling te maken hebben gekregen als adaptief en constructief.

Almqvist \& Hwang (1999) hebben in hun studie de copingstijlen van 39 Iraanse kinderen (leeftijd 4-7) en hun ouders onderzocht. Uit hun studie bleek dat zowel de kinderen als hun ouders een brede variatie van copingstijlen gebruikten. De ouders gebruikten vaak oplossingsgerichte en actieve copingstijlen, zoals verhuizen naar betere buurten en meer contact leggen met de bevolking. De kinderen gebruikten meer emotiegerichte copingstijlen, zoals positief denken en dagdromen. De ouders hadden bewust invloed uitgeoefend op de copingstijlen van hun kinderen, maar waren zelf ook enorm beïnvloed door de copingstijlen van hun kinderen. Priebe \& Esmaili (1998) hebben een studie gedaan onder Iraanse politieke vluchtelingen die slachtoffer waren van het politieke geweld en martelingen in Iran. Onder deze groep vluchtelingen komen depressieve symptomen, angst en posttraumatische symptomen vaak voor. Zij gebruikten variaties binnen de twee copingstijlen. Het hanteren van een variatie van copingstrategieën verwijst volgens de onderzoekers naar een goed adaptatievermogen van Iraanse vluchtelingen. Voor deze controverse (ernstige psychische klachten naast efficiënte copingstijlen) heb ik geen verklaring.

De stressbronnen waar vluchtelingen onder lijden, hebben te maken met diverse traumatische gebeurtenissen, zoals martelingen en geweld, oorlog, armoede in het vaderland en achterstandssituaties, gebrek aan sociale steun, sociale netwerken en acculturatiestress. Deze stressbronnen kunnen ervoor zorgen dat vluchtelingen minder doeltreffende, directe en probleemgerichte copingstijlen gaan hanteren (D'Avanzo et al., 1994; Frye \& D'Avanzo, 1994; Brennan \& Tamara, 1996; Trahan, 1995). Vooral de stress- en spanningsvolle situatie in het nieuwe land leidt tot het gebruik van passieve, afwachtende en/of vermijdende copingstijlen. Langdurige stress en niet goed verwerkte traumatische ervaringen worden in deze studies vaak in verband gebracht met emotiegerichte copingstijlen als palliatieve, vermijdende en afwachtende copingstijlen. Het positieve effect van sociale steun op de gebruikte copingstijl wordt ook in deze studies benadrukt.

Uit diverse meta-analyses blijkt dat probleem-focused coping (actieve copingstijl) positief samenhangt met een goede algemene gezondheid (Penley et al., 2002; Gunthert et al., 2005; Maas et al., 2009). Mensen die op een actieve manier met hun dagelijks leven 
omgaan en gericht zijn op hun toekomst in het nieuwe land, hanteren ook effectievere copingstijlen en hebben daardoor minder last van gevoelens van onzekerheid en frustraties. Het gebruik van adaptieve copingstijlen zoals toenaderingsgerichte coping is gerelateerd aan lagere niveaus van depressie (Lengua \& Stormshak, 2000; Penedo et al., 2001; Zeidner, 2006).

Bala et al. (2003) onderzochten copingstrategieën bij asielzoekers. Zij stelden dat asielzoekers die zichzelf als slachtoffers zien, vaker gezondheidsproblemen hebben. Ze geloven dat zij zelf niets kunnen veranderen aan de situatie en hun eigen positie. Vaak zijn hun sociale contacten minimaal en zijn de activiteiten gereduceerd tot wat noodzakelijk is.

Kramer \& Bala (2004) onderscheiden vier verschillende copingstijlen bij vluchtelingen: the drifter, the fighter, the explorer en the hibernator. Vluchtelingen hebben volgens Kramer $\&$ Bala de neiging diverse stijlen te hanteren. Nieuwe ervaringen, tijd en diverse omgevingsfactoren zijn van invloed op de copingstijlen die ze hanteren.

Uit de studies van Gil (2005), Olff et al. (2005), Kleber \& Brom (2003), Gil \& Caspi (2006), Ullman \& Fillipas (2005) en Schnider et al. (2007) blijkt dat er een duidelijke relatie bestaat tussen het ontwikkelen van PTSS-klachten en de copingstijl die mensen vaker hanteren. Uit deze studies blijkt dat het veelvuldige gebruik van emotiegerichte coping en weinig gebruik van oplossingsgerichte coping goede voorspellers zijn voor het ontstaan van PTSS. Vermijdende coping is volgens de uitkomsten van deze studies een significante voorspeller voor PTSS-klachten. Mensen met vermijdende copingstijl hebben meer last van psychische klachten na een traumatische ervaring (Benotsch et al., 2000; Waldrop \& Resick, 2004; Littleton et al., 2007). Daarnaast blijkt uit hun studies dat vermijdende copingstijl gerelateerd is aan meer depressieve klachten (Seiffge-Krenke \& Klessinger, 2000; Yamada et al., 2003; Mosher \& Prelow, 2007). Lindencrona et al. (2008) onderzochten in hun studie in hoeverre de capaciteit om om te gaan met spanningen van invloed is op de gevolgen van schokkende ervaringen in het land van herkomst en postmigratiespanningen. De capaciteit om met spanningen om te gaan bleek een bufferend effect te hebben op de symptomen van psychische stoornissen en posttraumatische stressstoornis.

\subsection{Copingstijl en ervaren begeleiding}

Een brug slaan tussen verleden, heden en toekomst vraagt van de vluchteling een effectieve copingstijl. ledere vluchteling die in het nieuwe land een goed leven wil opbouwen, dient zijn verleden een plek te geven. Continuïteit speelt bij het proces van 'betekenis geven' een belangrijke rol. Voor een vluchteling is het van essentieel belang om zijn leven op basis van de werkelijkheid vorm te geven en de twee culturen met elkaar te mengen. Uit studie van Beiser \& Hyman (1997) blijkt dat een goede en realistische tijdverdeling, positief omgaan met het verleden en gericht zijn op de toekomst positieve elementen zijn bij het hanteren van een effectieve copingstijl.

Begeleiding is een onmisbaar onderdeel van het integratieproces en is in de eerste 
plaats een beleidsinstrument van de overheid. Een goede en doelgerichte begeleiding stimuleert integratie, vergemakkelijkt het acculturatieproces en verbetert de copingstijlen. Begeleiding tijdens het integratieproces biedt de vluchteling de mogelijkheid om met de stressoren om te gaan door het hanteren van functionele en positieve copingstijlen. Positieve beleving van de begeleiding naar integratie brengt het gevoel van herwinning van macht en zelfvertrouwen teweeg.

Uit diverse studies blijkt dat sociale steun een bevorderend en positief effect heeft op het toepassen van effectieve copingstijlen (Cappeliez \& Flynn, 1993; Boomkamp, 2008).

Ajduković \& Ajduković (1993) kwamen op basis van hun studie onder vluchtelingen uit Zagreb en Kroatië tot de conclusie dat de sociale steun de belangrijkste voorspeller (predictor) is voor een succesvolle integratie en een goed aanpassingsproces. Zonke (1995) kwam ook tot dezelfde conclusie. Hij deed een onderzoek onder politieke vluchtelingen uit Zuid-Afrika die naar hun vaderland remigreerden. Hij concludeerde dat sociale steun de doorslaggevende factor is bij het hanteren van een effectieve copingstijl.

\subsection{De UCL: Utrechtse Copinglijst}

In deze studie is de Utrechtse Copinglijst (Schreurs et al., 1988) gebruikt om de copingstijlen van de respondenten in kaart te brengen. Deze copinglijst wordt vaak in Nederland gebruikt.

De UCL is een episodisch zelfrapportage-instrument dat de feitelijke wijze van probleemhantering beoogt te meten. Het instrument is geïnspireerd door de dispositionele copingvragenlijst van Westbroek en bevat 47 items waarvan er 44 zijn opgenomen in 7 schalen (Schaufeli \& Van Dierendonck, 1992).

De vragenlijst is gebaseerd op de opvatting dat copinggedrag een persoonlijkheidsstijl is. Het copinggedrag wordt niet gezien als een onveranderlijk gedrag, maar wel als een zodanig gedrag dat mensen een voorkeur hebben voor een bepaalde manier van gedrag. De test is in eerste instantie ontwikkeld om de invloed van de verschillende copingstijlen op stress en gezondheid in kaart te brengen.

UCL meet 7 copingstijlen die op basis van factoranalyse zijn geïdentificeerd, te weten:

- Actief aanpakken, confronteren: AC

- Palliatieve reactie (afleiding zoeken): PAL

- Vermijden, afwachten:VER

- Sociale steun zoeken: SOC

- Passief reactiepatroon: PAS

- Expressie van emoties: EXP

- Geruststellende en troostende gedachten gebruiken: GER 
Deze 7 items worden gescoord op een vierpuntenschaal (zelden of nooit, soms, vaak, zeer vaak). Er worden subscores berekend die met verschillende normgroepen vergeleken kunnen worden.

De interne consistentie van de subschalen is redelijk: ze variëren van .63 en .88. Ook de hertest-betrouwbaarheid is redelijk: variërend van .61 tot .79 na zes weken en van .51 tot .75 na een jaar. De intercorrelatie tussen de subschalen is vrij hoog, wat het bestaan van hogere-ordefactoren doet vermoeden (Schreurs et al., 1988).

\section{Conclusie:}

In dit hoofdstuk heb ik stilgestaan bij copingstijl. Het effect van copingstijl als een moderator op de relatie tussen de ervaren begeleiding wordt in onderzoek 1 onderzocht. Ik ben ervan uitgegaan dat coping een modererend effect heeft op de relatie tussen de kansperceptie en de begeleidingsfactoren. Deze hypothese is gebaseerd op het cognitieve model van Lazarus \& Folkman (1984). Ik verwacht op basis van de stresstheorie en het appraisal-model dat coping een modererend effect heeft op de relatie tussen de kansperceptie en begeleidingsvariabelen. In onderzoek 1 heb ik de modererende rol van copingstijl onderzocht en in onderzoek 3 krijgt de relatie tussen copingstrategieën, psychopathologie en de posttraumatische stressstoornis de aandacht.

Meer specifiek is de verwachting dat passieve en vermijdende copingstijlen de relatie tussen tevredenheid over de begeleiding en kansperceptie verminderen, omdat deze copingstijlen het aanpakken van problemen die integratie met zich meebrengt in de weg staan. De normaal gesproken positieve effecten van goede begeleiding worden tenietgedaan omdat de respondent geneigd is gebruik te maken van een coping-repertoire dat de kansen op succesvolle integratie vermindert. Daarentegen is de verwachting dat actieve coping en sociaal steunzoekende en geruststellende copingstrategieën de relatie tussen tevredenheid over de begeleiding en kansperceptie versterken omdat deze copingstijlen een positieve invloed hebben op integratie. Er is sprake van synergie tussen goede begeleiding en de benodigde coping. Deze moderatiehypothese wordt in onderzoek 1 getoetst. 


\section{Hoofdstuk 8}

\section{Algemene psychopathologie en posttraumatische stressklachten}

Wereldwijd bestaan er 16 tot 22 miljoen vluchtelingen. Een groot aantal van hen heeft direct of indirect te maken gehad met traumatische ervaringen. Naar schatting lijdt 25 tot $50 \%$ van de vluchtelingen aan posttraumatische stressstoornis, meestal in combinatie met depressie. Het leven van vluchtelingen is in vele gevallen gekenmerkt door extreme trauma's, spanningen, verlies en geweld. Vrees voor het eigen bestaan en voor het leven van familie en dierbaren dwingt veel mensen tot vluchten. Acculturatiestress, ontheemding, moeizame aanpassingsprocedures en sociaal isolement achtervolgen vluchtelingen in het nieuwe land. Hoewel er grote individuele verschillen bestaan met betrekking tot de omvang en de ernst van de trauma's, en ieders levensverhaal uniek is, blijkt dat een groot aantal vluchtelingen last heeft van psychische klachten: klachten die zich voordoen als gevolg van trauma's en/of life events.

Als laatste psychologische factor bespreek ik in deze studie dan ook de posttraumatische stressstoornis (PTSS). Eerst wordt het begrip posttraumatische stressstoornis besproken. Vervolgens wordt PTSS vanuit twee classificatiesystemen bekeken. De recente ontwikkelingen, factoren die PTSS in de hand werken, komen verder aan de orde. Daarna passeren de epidemiologie van PTSS en PTSS onder vluchtelingen de revue. Ten slotte wordt het veronderstelde effect van algemene psychopathologie en PTSS op de ervaren begeleiding besproken. Ik sluit dit hoofdstuk af met een kort overzicht van de gebruikte meetinstrumenten.

\subsection{Psychotrauma: definitie van het begrip}

Het Griekse woord 'trauma' betekent wond of letsel. Het woord trauma werd tot in de vorige eeuw vooral gebruikt om de lichamelijke beschadigingen door mechanisch geweld aan te duiden.

In de literatuur wordt psychisch trauma vaak beschreven als een zeer extreme en acute gebeurtenis die levensbedreigend is en die het individu overspoelt en hulpeloos maakt. Trauma is een buitengewone en extreme aangelegenheid die voor iedereen overweldigend moet zijn (DSM-IV).

PTSS kan worden gezien als een gewone, menselijke reactie op ongewone, extreme situaties. ledere schokkende gebeurtenis die buiten de patronen van het dagelijks leven valt, kan volgens deze opvatting traumatisch zijn. Volgens de DSM-IV kwalificeren zich alleen gebeurtenissen die de lichamelijke integriteit bedreigen. De 'posttraumatische stressstoornis' treedt op wanneer mensen een ingrijpende gebeurtenis of situatie niet goed hebben verwerkt. De aanvankelijke reactie op de schokkende gebeurtenissen wordt 
door velen gezien als 'een normale reactie op de abnormale gebeurtenis(sen)'. Pas als deze reactie blijft bestaan en zich ontwikkelt tot een chronisch probleem, wordt er van een stoornis gesproken. PTSS wordt gekenmerkt door herbelevingen, vermijding van traumagerelateerde stimuli of afstomping en een verhoogde prikkelbaarheid.

De belangrijkste kenmerken van PTSS worden als volgt beschreven:

- Herbeleving van traumatische ervaringen door indringende herinneringen (flashbacks) en dromen.

- Gedrag dat gericht is op het vermijden van alle situaties en de prikkels die op een of andere wijze verbonden zijn met de traumatische ervaringen.

- Verhoogde prikkelbaarheid, problemen bij het inslapen, concentratiestoornissen of agressieve uitbarstingen.

Men spreekt van psychotrauma wanneer een persoon geconfronteerd wordt met prikkels die de gebeurtenissen representeren en waardoor onaangename fysiologische en psychologische reacties optreden (Kingma, 1999). Als symptomen zich nog steeds manifesteren na drie maanden na het psychotrauma, worden ze als kenmerken van PTSS gezien. Toch bestaat hierover geen vaste regel. Het kan soms ook jaren duren voordat de verschijnselen zich openbaren. Wanneer de symptomen zich voordoen meteen na het trauma en ze niet langer dan vier weken aanhouden, spreekt men van een acute PTSS, of dit nu een stoornis is of een normaal reactiepatroon. Uit diverse onderzoeken is wel gebleken dat bepaalde en herhaaldelijke blootstellingen aan traumatische gebeurtenissen een groter risico lijken te vormen voor het ontwikkelen van PTSS dan andere (Carlson, 2002; Ozer et al., 2003; Sadock \& Sadock, 2003; Neuner et al., 2004; Keane et al., 2006).

\subsection{Classificatiesystemen en PTSS}

Het gebruik van psychiatrische classificatiesystemen bij posttraumatische reacties heeft twee belangrijke voordelen. In de eerste plaats geven ze een geruststellende uitleg: over wat de omgeving als zwakte, krankzinnigheid of aanstellerij typeert. Dit wordt benoemd als een begrijpelijke en in die zin een normale reactie op extreme, pijnlijke en verdrietige ervaringen. In de tweede plaats stellen de classificatiesystemen de hulpverlener in staat om een bondige eerste typering te geven van de problematiek. Het gebruik van classificatiesystemen helpt de hulpverlener om gerichte vragen te kunnen stellen en daardoor krijgt de vluchteling de kans om zijn klachten onder woorden te brengen (Van der Veer, 1998).

In de vierde versie van het diagnostische handboek (DSM-IV) wordt PTSS onder de categorie angststoornissen met code 309.81 gebracht.

In DSM-IV (APA, 2004) wordt trauma beschreven als: het ervaren van, getuige zijn van of geconfronteerd worden met een gebeurtenis of gebeurtenissen waarbij sprake is van feitelijk of dreigend overlijden of ernstig letsel, of bedreiging van de fysieke integriteit 
van zichzelf of anderen. Kenmerkend voor een trauma is ook dat het subjectieve reacties oproept van intense angst, hulpeloosheid of afgrijzen (APA, 2004). In DSM-IV worden de volgende algemene kenmerken van PTSS beschreven:

- Herbeleving van traumatische ervaringen door indringende herinneringen of dromen, zich gedragen of voelen alsof de traumatische gebeurtenissen opnieuw plaatsvinden.

- Vermijdingsgedrag en afstomping ten opzichte van alle prikkels die op een of andere manier verbonden zijn met traumatische belevenissen.

- Verhoogde 'arousal': bij een posttraumatische stressstoornis zijn er aanhoudend verschijnselen van verhoogde 'arousal' of prikkelbaarheid, zoals problemen bij het inslapen, concentratieproblemen of agressieve uitbarstingen.

DSM-IV stelt eisen ten opzichte van de ernst en de duur van de symptomen. De stoornis moet een duidelijke verslechtering van het functioneren op één of meer levensgebieden teweegbrengen. Bovendien moeten de symptomen minimaal een maand aanwezig zijn. Opvallend in de DSM-IV-definitie is dat niet iedere schokkende gebeurtenis die buiten het patroon van het normale leven valt aanleiding geeft tot PTSS. Er moet sprake zijn van directe fysieke bedreiging (denk aan dood).

In het classificatiesysteem van de World Health Organization (ICD-10) wordt PTSS in verband gebracht met persoonlijkheidsveranderingen. Een belangrijk kenmerk van PTSS wordt beschreven als 'blijvende persoonlijkheidsverandering na catastrofale stress'. De effecten van traumatische gebeurtenissen zoals concentratiekampen, gevangenschap, langdurig blootstellen aan levensgevaarlijke situaties, marteling en ingrijpende rampen komen aan de orde. Volgens de ICD-10-classificatie kunnen levensbedreigende situaties leiden tot gevoelens van vijandigheid en wantrouwen tegenover de hele wereld. Het gevolg daarvan is een blijvende persoonlijkheidsverandering van het slachtoffer.

Het gebruik van de classificatiesystemen wordt niet zonder kritiek overal geaccepteerd. Eén van de kritiekpunten betreft de methodologie van gebruikte systemen.

De classificatiesystemen bieden geen uitgewerkte psychologische verklaring voor het ontstaan van de stoornis en ook geen aanknopingspunten voor de psychologische behandelingsmethoden. Een andere kritiek betreft het onderschatten van het belang van de culturele aspecten bij het ontstaan van traumatische stoornissen en bij het indicatie stellen (Van Dijk, 1995; Van der Veer, 1998; Kleber, 1996; Withuis, 1995). De diagnostische criteria berusten op de westerse culturele en medische aspecten. De context en de culturele aspecten waarin een reactie zich voordoet, worden in de classificatiesystemen onderschat.

Rijnders (2002) maakt een onderscheid tussen PTSS en angst voor bijvoorbeeld uitzetting. Hij spreekt in dit geval van de actuele stressstoornis (ASS). Volgens Rijnders kunnen ook mengbeelden hiervan voorkomen. Volgens Rohlof (2003) kunnen migratie en acculturatiestress de diagnostiek en behandeling van PTSS-klachten compliceren. 


\subsection{Recente ontwikkelingen}

De stressbenadering neemt een centrale plaats in bij recente ontwikkelingen in het begrijpen van de verwerking van trauma's. In de recente studies over stress is meer aandacht voor de effecten van de omgevingsfactoren zoals werkloosheid, werkconflicten en andere moeilijke situaties die de psychische balans in gevaar kunnen brengen. Hoewel zulke factoren volgens de DSM-IV niet tot de trauma's horen die tot PTSS kunnen leiden, kunnen ze wel degelijk PTSS-symptomen en zelfs het gehele syndroom veroorzaken (Mol et al., 2005; Van der Klink \& Terluin, 2005). Daarnaast werken deze factoren als 'luxerende factoren' bij het tot stand komen van PTSS ten gevolge van oude traumatische ervaringen. Deze factoren worden vaak onder de term 'life events' geschaard. De basale kenmerken van PTSS blijken universeel te zijn (Taylor, 2006).

Traumatische ervaringen en/of life events zouden ertoe kunnen leiden dat mensen psychische en psychosomatische klachten gaan ontwikkelen. Tegenwoordig overlappen de onderzoeken op het gebied van stress en trauma elkaar. Een voorbeeld hiervan is het begrip 'stress-responssyndroom' van Horowitz (1979, 1986). Hij beschreef een algemeen stress-responsesyndroom dat optreedt na diep ingrijpende ervaringen. Het syndroom zou in vijf fasen verlopen: outcry, ontkenning, herbeleving, doorwerken en voltooiing. Het syndroom wordt beschouwd als een fasepatroon van verwerking van extreme gebeurtenissen, waarbij twee algemene categorieën van processen centraal staan: ontkenning en intrusion.

Lifton (1979) categoriseert het verwerkingsproces van de overlevenden van Hiroshima als een terechte reactie op een schokkende beleving. Herbeleving van de doorgemaakte gebeurtenissen, vermijdingsgedrag, apathie en zoeken naar een betekenis voor de schokkende gebeurtenissen benoemt hij als traumatisch syndroom. Als deze reacties het normale functioneren van een persoon in het dagelijks leven in de weg staan, is er sprake van een traumatische neurose.

\subsection{Factoren die bijdragen aan PTSS}

In de literatuur verwijst men naar twee groepen factoren die bijdragen aan het ontstaan van PTSS-klachten: de individuele en psychologische factoren (bijvoorbeeld persoonlijkheidsaspecten en copingstijl) en omgevingsfactoren (bijvoorbeeld sociale steun).

Een van de belangrijkste persoonlijkheidsaspecten is de 'locus of control' (Rotter, 1966; Thompson et al., 1998). lemand met een interne locus of control is ervan overtuigd dat hij zelf zijn eigen leven onder controle heeft. Hij zal zich meer inspannen om zijn problemen op te lossen. Daartegenover staat externe locus of control. Dit verwijst naar het besef dat de persoon vooral door de buitenwereld en door externe factoren wordt begeleid en de rol van de persoon zelf wordt onderschat. Deze persoon zal meer gevoelens van angst en machteloosheid ervaren. Volgens deze theorie is het positief en bevorderlijk voor het 
gevoel van 'zelfvertrouwen' als een persoon controle kan uitoefenen over zijn gedachten.

Een andere psychologische factor waarin de rol van de persoonlijke inbreng benadrukt wordt, is de theorie van copingstijl. Het bewust hanteren van een bepaalde copingstijl om het probleem uit de wereld te helpen, impliceert de individuele keuze en de verschillen tussen mensen. Mensen met actieve en probleemgerichte copingstijlen blijken beter met de nasleep van traumatische ervaringen om te gaan. Mensen die gekenmerkt worden door cognitieve complexiteit (dat wil zeggen: meer rollen en zelfbeelden), functioneren sneller op een goed niveau (Kleber, 2000; Brewin et al., 2000).

Hoe mensen situaties beoordelen heeft te maken met hun persoonlijkheidskenmerken en met (in)adequate copingstrategieën waarover zij beschikken (Ai et al., 2007). Lazarus (1984) was van mening dat er een verband bestaat tussen copingstijl en de cognitieve beleving van de persoon enerzijds, en de wijze waarop mensen hun mening/oordeel geven over de stressvolle en ingrijpende situatie anderzijds.

Behalve individuele factoren spelen ook omgevingsfactoren een belangrijke rol bij het ontwikkelen van PTSS. De mate van sociale steun die mensen uit hun eigen omgeving en hun sociale milieu ter beschikking krijgen, beïnvloedt hun reactie(s).

De volgende elementen blijken invloed uit te oefenen op de mate waarin de posttraumatische reacties zich voordoen (Kleber, 2000):

- Hoe chronischer een situatie, des te meer problematiek. Langdurig lijden aan trauma veroorzaakt meer psychopathologie dan een eenmalige gebeurtenis.

- Hoe meer een gebeurtenis één persoon alleen treft, des te meer stoornissen. Gedeelde rampen zoals overstromingen en aardbevingen leiden tot minder heftige psychische reacties dan bijvoorbeeld geweld dat een individuele burger op straat of in zijn huis treft.

- Hoe meer een gebeurtenis sociaal beladen is, des te meer stoornissen. Een verkrachting blijkt in ruim een kwart tot bijna de helft van de gevallen tot ernstige psychische stoornissen te leiden.

Uit verschillende studies blijkt dat er een verband bestaat tussen het aantal traumatische gebeurtenissen en de mate van PTSS in de algemene populatie en ook bij vluchtelingenpopulaties (Ai et al., 2002; Lloyd \& Turner, 2003; Neuner et al., 2004). Negatieve interpretatie van herinneringen aan trauma blijkt positief te correleren met de PTSS-symptomen (Lommen et al., 2008).

\subsection{Epidemiologie van PTSS}

Epidemiologische studie toont aan dat 92\% van de mensen ooit in hun leven een schokkende gebeurtenis heeft meegemaakt. De meest voorkomende traumatische gebeurtenissen zijn verkeersongevallen, mishandelingen, geweld op straat, de onverwachte dood van een dierbare persoon en het getuige zijn van iets ernstigs dat een ander in de nabije omgeving overkomt (Kleber, 2000). 
In verschillende studies wordt de epidemiologie van PTSS beschreven. Ozer et al. (2003) noemen in hun meta-analyses een prevalentie van 9,2\% onder volwassen burgers. Olff \& De Vries (2004) en Singareddy \& Balon (2002) vermelden een soortgelijke prevalentie in hun onderzoek van 7,8 tot $9,2 \%$. Waarom dezelfde ingrijpende ervaring bij sommige mensen leidt tot PTSS en bij anderen niet, is niet helemaal duidelijk. Er is wel veel onderzoek gedaan naar risicofactoren die een rol kunnen spelen bij het ontstaan van PTSS. Schnurr et al. (2002) en Ullman \& Fillipas (2005) komen op basis van hun onderzoeken tot de conclusie dat de kans op het ontwikkelen van PTSS voor vrouwen vier keer hoger is dan voor mannen. Ook een lage leeftijd en een lager opleidingsniveau kunnen de kans op het ontwikkelen van PTSS vergroten. Johnson \& Thompson (2007) beschrijven in hun onderzoek dat er wellicht verschillen bestaan in de posttraumatische reacties van oorlogsveteranen en burgerslachtoffers. Soldaten worden getraind om zich voor te bereiden. Het gevolg hiervan is dat burgerslachtoffers vaker last hebben van indringende herinneringen, terwijl soldaten eerder emotionele verdoofdheid en schuldgevoelens ervaren.

Uit meta-analyse van 7000 vluchtelingen door Fazel et al. (2005) bleek dat 7-17\% van de vluchtelingen voldoet aan de diagnose PTSS.

\subsection{PTSS bij vluchtelingen}

Vele vluchtelingen komen uit landen waar de mensenrechten op systematische en soms op zeer gruwelijke wijze worden geschonden. Na de aankomst in het gastland bevinden ze zich meestal in een onzekere situatie. Daarnaast worden ze geconfronteerd met andere stressbronnen. Door het verlies van vertrouwde figuren, structuren, netwerkmogelijkheden, de langdurige asielprocedure, het klimaat, de taal en de werkloosheid herbeleven ze het gevoel van machteloosheid. Er zijn schattingen over de omvang van de psychische klachten onder asielzoekers en vluchtelingen. Er blijkt diversiteit te bestaan ten opzichte van individuele verschillen per land en cultuur. Volgens een onderzoek van Hondius \& Van Willigen (1992) lijdt 12\% van de asielzoekers aan PTSS of aspecifieke klachten zoals depressie, angst en psychosomatische klachten. Deze inschatting is gebaseerd op gegevens over mensen die werden doorverwezen naar eerstelijnszorg. Vermoedelijk liggen de feitelijke cijfers veel hoger, omdat diverse groepen vluchtelingen verborgen klachten hebben of helemaal geen hulp zoeken. Uit onderzoek van Heptinstall et al. (2004) blijkt dat de onzekerheid over het verkrijgen van een verblijfsvergunning een belangrijke invloed heeft op zowel PTSS als depressie.

$20 \%$ van de vluchtelingen ontwikkelt PTSS na een traumatische ervaring (Ang, 2007). Trauma en PTSS zijn ingebed in een socioculturele realiteit. Traumatische ervaringen bij vluchtelingen zijn complex en hebben meer lading.

Het huidige toelatings- en opvangbeleid in de eerste fase van het verblijf in Nederland, het inburgeringsbeleid en de langdurige werkloosheid, en het sociale isolement zouden onder andere zorgen voor gezondheidsklachten (Gerritsen et al., 2007). Van Willigen et al. 
(1995) noemen de opeenvolging van traumatische gebeurtenissen en de spanningen die vluchtelingen in het gastland ervaren als een sequentie of cumulatieve traumatisering. Van der Veer (1991) maakt een verdeling in traumatische ervaringen die vluchtelingen hebben meegemaakt. De belangrijkste oorzaken brengt hij onder in 7 categorieën: onderdrukking, martelingen, terreurervaring, slagveldervaring, scheiding en verlies, ontbering en ballingschap.

Ondanks alle problemen die vluchtelingen hebben meegemaakt, klopt een deel van hen niet aan bij hulpverleningsorganisaties. Sommige vluchtelingen weten zich uitstekend te redden. Bij een aantal anderen doen zich allerlei psychische en psychosomatische klachten voor na het doorlopen van diverse integratiefasen. Dit kan plaatsvinden als een nieuwe gebeurtenis hen onverwacht confronteert met een traumatische ervaring uit hun verleden. Soms kan een ervaring die een associatie heeft met het verleden, het evenwicht tussen draagkracht en draaglast verstoren en psychische reacties teweegbrengen.

Behalve specifieke klachten van PTSS, blijkt dat vluchtelingen te kampen hebben met aspecifieke klachten zoals angst, depressie, slapeloosheid, concentratiestoornissen, geheugenproblemen en diverse psychosomatische klachten (Lamkaddem et al., 2005; Devillé et al., 2006; Gerritsen et al., 2007). De aspecifieke klachten worden gezien als uiting van een normaal verwerkingsproces van de opeenvolgende schokkende ervaringen. Bij vluchtelingen gaan de symptomen van PTSS samen met depressieve symptomen, zoals vermindering van interesse en plezier in activiteiten, angstreacties, maar ook bizarre gedragingen, achterdocht en paranoïde gedrag. Gevolgen van deze psychische problemen beperken zich niet tot microniveau, bijvoorbeeld tot het gezins- en het privéleven van vluchtelingen. Er is dan ook sprake van een probleem voor de hele samenleving en dus op macroniveau, met name de gezondheidszorgkosten en de arbeidsmarkt.

Uit diverse studies blijkt dat vluchtelingen meer last hebben van diverse psychische klachten en vooral PTSS-klachten dan de normale bevolking. (Silove et al., 2002; Fazel et al., 2005; Gerritsen et al., 2006, 2007). Jaukov (2002) ziet de postmigratiefactoren, vooral het langdurige verblijf in een azc en diverse en langdurige procedures, als zeer belastende factoren voor het verwerken van de meegemaakte trauma's die vluchtelingen in het land van herkomst hebben meegemaakt. Uit de grootschalige studie van Toar et al. (2009) in lerland bleek dat $63 \%$ van de asielzoekers symptomen van PTSS vertoont. Ze zagen bij $73,3 \%$ van de asielzoekers symptomen van angst en depressie. Schwarz-Nielsen \& Elklit (2009) rapporteren een hoge mate van PTSS-symptomen gemeten met HTQ onder asielzoekers (77\%). Ze vonden bij $94 \%$ van de onderzochte (afgewezen) asielzoekers symptomen van angst en bij $100 \%$ symptomen van depressie.

Een snelle interventie, het bepalen van de mate van kwetsbaarheid en de gehanteerde copingstijlen blijken belangrijke voorspellers te zijn voor het ontstaan van PTSS-klachten (Gil, 2005; Schnider et al., 2007). Een oorlogservaring wordt gezien als een belangrijke risicofactor voor PTSS-klachten (Ai et al., 2002; Al-Saffar et al., 2003). 


\subsection{Traumatisering en ervaren begeleiding}

Het contact met de cultuur van het gastland vereist aanpassing van de vluchtelingen. Het acculturatieproces brengt de nodige spanningen op individueel, gezins- en groepsniveau met zich mee. Hoe groter de druk op snelle en eenzijdige aanpassing aan de cultuur van de dominante groep, hoe ernstiger de spanning (Williams \& Berry, 1991). Aanpassing is een langdurig proces, vraagt tijd en financiële investering van het gastland. Voor de vluchteling betekent het dat hij zijn bestaan opnieuw een impuls moet geven. Zingeving van het bestaan en het verwerven van een plek in het gastland na alle trauma's die een vluchteling heeft meegemaakt, lopen niet altijd even gemakkelijk. Vluchtelingen hebben gedurende het proces van aanpassing sociale en maatschappelijke ondersteuning nodig.

Daarom is het naar mijn mening belangrijk dat de vluchteling tijdens verschillende integratiefasen en zolang hij/zij niet zelfstandig in de samenleving kan functioneren over een goede en passende begeleiding beschikt. Deze begeleiding dient bij de vluchtelingen het vertrouwen te wekken en het gevoel teweeg te brengen dat hun kansen op positieverbetering in Nederland stijgen, naast en ondanks alle trauma's die ze hebben meegemaakt.

Vooral voor getraumatiseerde vluchtelingen die door diverse trauma's psychische en somatische klachten hebben ontwikkeld, is het belangrijk om goede en passende begeleiding te krijgen.

Vanwege het hoge niveau van stressvolle en traumatiserende ervaringen bij asielzoekers en vluchtelingen, worden hoge scores op algemene psychopathologische klachten verwacht. Verder wordt verwacht dat algemene psychopathologie de positieve relatie tussen tevredenheid over de ontvangen begeleiding en integratiekansen vermindert. Dit, omdat ik verwacht dat deze klachten mogelijkerwijze verhinderen om optimisme op te bouwen op basis van de begeleiding. In de eerste studie is daarom het modererende effect van algemene psychopathologieklachten op de perceptie van kansen onderzocht. In onderzoek 3 heb ik getracht de mate van PTSS-klachten in kaart te brengen, om na te gaan of algemene psychopathologische klachten vooral gezien moeten worden als een gevolg van PTSS, of dat de psychische problematiek bij vluchtelingen breder is. Verder is nagegaan of er verbanden bestaan tussen bepaalde soorten van copingstijlen en de ervaren last van PTSS.

\subsection{Meetinstrumenten}

Ik heb in deze studie drie vragenlijsten gebruikt om de mate van psychopathologie en de PTSS-klachten in kaart te brengen: de klachtenlijst SCL-90, de Harvard Trauma Vragenlijst (HTQ) en de PTSS Symptom Scale (PSS). Hieronder volgt een korte beschrijving van deze vragenlijsten. 


\subsubsection{De SCL-90: symptoom checklijst}

Op deze klachtenlijst kan de persoon aangeven in hoeverre hij in de afgelopen periode last heeft gehad van psychische en lichamelijke klachten. Deze vragenlijst meet het psychische disfunctioneren van iemand en geeft ook informatie over 9 specifieke, klinische dimensies, te weten:

1. Agorafobie: een buitengewone reactie van vrees in openbare ruimten en in openbare gelegenheden, waarbij de persoon zich zwak voelt of bang is om de beheersing te verliezen.

2. Angst: klachten of symptomen die samenhangen met onheilsgevoelens, angstige gedachten, zenuwachtigheid, spanning, paniekaanvallen en rusteloosheid.

3. Depressie: klachten wat betreft neerslachtige stemming, onvermogen om te genieten, verlaagde zelfwaardering, schuldgevoel, hopeloosheid, dood en zelfmoord. Bij deze schaal hoort ook een aantal lichamelijke klachten.

4. Somatische klachten: klachten die met een algemeen gevoel van lichamelijk disfunctioneren samenhangen, en door psychische factoren kunnen ontstaan.

5. Insufficiëntie van denken en handelen: gedachten, impulsen en problemen bij het uitvoeren van gedragingen die als dwingend en buiten de eigen wil worden ervaren.

6. Wantrouwen en interpersoonlijke sensitiviteit: grondtoon van onvrede met het zelf in relatie tot andere mensen. Deze onvrede kan zowel naar buiten worden geprojecteerd, alsook worden ervaren als een gevoel van persoonlijke inadequatie en inefficiëntie in het contact met andere mensen.

7. Hostiliteit: gedachten, gevoelens of gedragingen die kenmerkend zijn voor de negatieve gemoedstoestand van woede.

8. Slaapprobleem: problemen met betrekking tot slapen (in- en doorslapen).

9. Totaal score (PSNEUR): psychoneuroticisme en somatisch onwelbevinden.

De SCL-90 is afgenomen bij beide kwantitatieve onderzoeken 1 en 3.

\subsubsection{De Harvard Trauma Questionnaire (HTQ)}

De HTQ is een zelfbeoordelingsvragenlijst die door Mollica et al. $(1992,1996,2004)$ is ontwikkeld. De vragenlijst meet geweldservaringen en PTSS-symptomen in verschillende culturele populaties. De HTQ bestaat uit vier onderdelen:

- Deel één bestaat uit 17 traumatische gebeurtenissen, zoals verkrachting, marteling of de moord op familie of vrienden. Mensen kunnen aangeven of ze het 'zelf hebben meegemaakt', er 'getuige van zijn geweest', 'erover gehoord hebben' of geen van dit alles.

- Deel twee is een beschrijvende vraag. Cliënten wordt gevraagd om de meest traumatische ervaring die ze hebben meegemaakt te beschrijven. Later en in de Nederlandstalige versie is deze vraag vervangen door 3 items over de oorspronkelijke gebeurtenis.

- In deel drie staan 4 vragen over traumatische ervaringen waardoor eventueel ook hoofdverwondingen zijn opgelopen. 
- Deel vier bestaat uit 30 items over traumatische stresssymptomen. De eerste 16 vragen zijn afgeleid van DSM-IV-criteria. De resterende 14 items gaan over symptomen die betrekking hebben op de doorgemaakte trauma's.

In deze studie wordt de Farsi-versie van de onderdelen één en vier gebruikt.

\subsubsection{De PTSS Symptom Scale (PSS)}

De PSS is een zelfrapportagevragenlijst ontwikkeld door Foa et al. $(1993,1997)$. De PSS correspondeert met de 17 DSM-IV-symptomen. Deze vragenlijst kan worden gebruikt als eerste screening om te weten of iemand aan de criteria van PTSS voldoet. Foa et al. (1993) rapporteerden een goede betrouwbaarheid en overeenstemming met het gestructureerde interview voor DSM-III-R (SCID).

De vertaalde versie in het Nederlands bestaat uit 20 vragen met 4 antwoordmogelijkheden waarmee in kaart wordt gebracht in hoeverre de persoon last heeft van PTSS-symptomen in de afgelopen week ( 0 = nooit; 1 = één keer; $2=$ twee tot vier keer; $3=$ vijf keer). De ruwe score wordt berekend door het optellen van de cijfers. Degenen die boven 27 scoren, worden 'gediagnosticeerd' als lijdend aan PTSS. Een ruwe score boven 14.1 is een indicator voor het bestaan van een angststoornis. Op basis van PSS is het mogelijk om een differentiële diagnose te stellen tussen PTSS, de overige angststoornissen en de normale populatie.

In de studie van Engelhard et al. (2007) is een Cronbach's alpha van 0.95 voor de hele onderzoeksgroep gevonden. Voor de PTSS-groep is de Cronbach's alpha 0.85.

Voor PSS bestaat een versie in het Farsi. Deze vertaalde versie heb ik gebruikt in onderzoek 3. 

Deel III

Methode 


\section{Hoofdstuk 9}

\section{Methode van onderzoek}

Dit hoofdstuk behandelt van alle drie onderzoeken de onderzoeksmethode. Achtereenvolgens komen per onderzoek aan de orde: procedure, kenmerken van de onderzoeksgroep, methodologische verantwoording van het onderzoek (waaronder de representativiteit, validiteit en betrouwbaarheid) en een beschrijving van de meetinstrumenten (waaronder de operationalisering van de variabelen en de constructie van de schalen).

\subsection{Onderzoek 1: Correlationeel onderzoek naar de relatie van ervaren begeleiding en waargenomen kansen}

Het eerste onderzoek is een correlationeel onderzoek, gebruikmakend van een viertal vragenlijsten. Het onderzoek heeft plaatsgevonden tussen 2004-2007 onder Iraanse asielzoekers en (ex-)vluchtelingen verspreid over Nederland.

\subsubsection{Kenmerken van de onderzoeksgroep}

De onderzoeksgroep bestaat uit asielzoekers en (ex-)vluchtelingen uit Iran.

Onder de categorie asielzoeker valt iedereen die in de asielprocedure zit en ook asielzoekers die afgewezen zijn en toch in beroep zijn gegaan tegen de beslissing van de IND. De groep asielzoekers was woonachtig in asielzoekerscentra (azc's), COA-woningen en/of bij hun familie en kennissen.

De groep (ex-)vluchtelingen die in het bezit is van een permanente verblijfsvergunning of de Nederlandse nationaliteit woonde voor een groot deel in huurwoningen en/of in een eigen woning.

Bij het verzamelen van de gegevens heb ik geen specifieke eisen gesteld. Alle Iraniërs die ouder waren dan 18 jaar en in Nederland asiel hebben aangevraagd en/of in het bezit waren van een verblijfsvergunning, mochten deelnemen aan het onderzoek.

Ook kinderen van asielzoekers en (ex-)vluchtelingen die zelf geen beroep hebben gedaan op de vluchtelingenwet, maar samen met hun ouders in Nederland woonden en ouder waren dan 18 jaar, mochten deelnemen aan het onderzoek.

Respondenten waren over het algemeen bekend met het invullen van 'meerkeuzevragenlijsten'.

Wat de samenstelling van de steekproef betreft, is er bewust gekozen voor heterogeniteit met betrekking tot leeftijd en opleidingsniveau. 


\subsubsection{Procedure}

Na een lange voorbereidingsfase in 2002-2003, zijn de data voor kwantitatief onderzoek 1 in 2004-2007 verzameld en geanalyseerd. In die periode zijn er 72 asielzoekers en 76 (ex-)vluchtelingen schriftelijk geënquêteerd. Asielzoekers die aan het onderzoek hebben deelgenomen, woonden verspreid over Nederland, in verschillende asielzoekerscentra en in de COA-woningen, onder andere in Leusden, Amersfoort, Doorn, Delft, Arnhem en Amsterdam. De groep (ex-)vluchtelingen woonde verspreid over Nederland.

Voor de werving van asielzoekers heb ik een beroep gedaan op de directeuren van enkele azc's in de provincie Utrecht. Er namen ook asielzoekers van andere provincies deel aan het onderzoek. Ze zijn benaderd door de asielzoekers die woonachtig waren in de provincie Utrecht.

In eerste instantie werden alle asielzoekerscentra in Amsterdam en in de provincie Utrecht schriftelijk benaderd om hun medewerking te verlenen.

In de brieven stond dat twee weken na de ontvangst van de brief contact zou worden opgenomen met de directie. Directeuren die hun medewerking toezegden, werden verder telefonisch geïnformeerd over het doel en de inhoud van het onderzoek en hun vragen werden beantwoord door de onderzoekster.

In tweede instantie werden onderzoeksdata afgesproken met de directeuren.

Vervolgens heb ik twee brieven aan de directeuren gestuurd: één voor de azc's in het Nederlands en één voor de asielzoekers in het Farsi.

In de brieven voor de asielzoekers ben ik gedetailleerd ingegaan op de inhoud, het doel, de datum en de locatie van het onderzoek. In de brieven stond informatie over de gebruikte vragenlijsten. De informatiebrief werd op de prikborden van de azc's opgehangen. Op de afgesproken data konden respondenten de locatie van het onderzoek binnenkomen en na de kennismaking met mij werd de instructie van de vragenlijsten uitgelegd. Over het algemeen bestond iedere onderzoeksgroep uit 3 tot 5 personen.

$\mathrm{Na}$ de afname werd met iedereen afspraken gemaakt om de uitslagen van de vragenlijsten door te nemen.

De groep (ex-)vluchtelingen werd samengesteld uit mijn eigen netwerk en de Iraanse (ex-)vluchtelingen verspreid over Nederland.

In 2004 werd een bijeenkomst georganiseerd voor de Iraanse en Afghaanse vluchtelingen door de gemeente Amersfoort. In die bijeenkomst werd door de onderzoekster van deze studie informatie gegeven over de geestelijke gezondheid van de vluchtelingen. Bij de bijeenkomst waren veel Iraniërs aanwezig. Aan het eind van de lezing werden de deelnemers geïnformeerd over het onderzoek en gevraagd of ze wilden deelnemen aan het onderzoek. Diegenen die geïnteresseerd waren, mochten de vragenlijsten ter plekke invullen of mee naar huis nemen. De ingevulde vragenlijsten konden de respondenten in gefrankeerde enveloppen terugsturen of overhandigen aan de trajectbegeleider van de gemeente Amersfoort. De vereniging van Iraanse vluchtelingen en de stichting van vluchtelingenstudenten werden ook geïnformeerd over het onderzoek. De vragenlijsteninstructies werden zowel mondeling als schriftelijk uitgelegd. 
Alle respondenten konden de uitslagen van het onderzoek schriftelijk ontvangen. Naast het individuele vragenlijstprofiel kreeg iedere deelnemer inhoudelijke informatie over de vier gebruikte vragenlijsten: De Beck Depressie-vragenlijst, de SCL-90, de UCL en de begeleidingsvragenlijst over de ervaren begeleiding naar integratie. Daarnaast mochten alle respondenten telefonisch contact opnemen met mij over de eventueel bestaande vragen.

In de praktijk was het zeer moeilijk om de groep (ex-)vluchtelingen te bereiken. Meer dan 400 vluchtelingen ontvingen de vragenlijsten, maar uiteindelijk hebben 76 personen $(22,5 \%)$ de vragenlijsten ingevuld en teruggestuurd.

Het is mij niet duidelijk waarom ik zo weinig reacties van de groep (ex-) vluchtelingen heb ontvangen (non-responsverschijnsel). Mijn hypothese is dat de volgende factoren hierop invloed hebben gehad: de omvang van de vragenlijsten, weinig motivatie, geen direct belang, weinig tijd en twijfel over de effecten van het onderzoek op hun levenssituatie.

\subsubsection{Meetinstrumenten}

Voor onderzoek 1 heb ik vier vragenlijsten gebruikt: drie standaardvragenlijsten die regelmatig in de klinische praktijk gebruikt worden en een zelfontworpen vragenlijst over de wijze waarop respondenten hun begeleiding naar integratie hebben ervaren (begeleidingsvragenlijst).

Hieronder volgt een korte beschrijving van de gebruikte vragenlijsten bij onderzoek 1:

\section{De Beck Depressie-vragenlijst (BDI):}

Deze vragenlijst bestaat uit enkele uitspraken die bij elkaar staan. De BDI is een 21-items, zelfrapportagevragenlijst met een 4-punts Likert-schaal. Er is sprake van een cumulatief meetmodel (Wiggins, 1973) dat overeen lijkt te stemmen met het klinische beeld van depressie. Hoe meer symptomen voorkomen, hoe ernstiger de depressie is (Van den Hoofdakker, 1978). De vragenlijst brengt 21 symptomen van depressie in kaart. De symptomen worden geformuleerd in de vorm van stellingen. ledere stelling krijgt een cijfer. De cijfers lopen van 0 (geen) tot 4 (zeer hoog). De som van de cijfers bepaalt de mate van depressie.

De Beck-vragenlijst wordt regelmatig zowel in Iran als in Nederland in de klinische praktijk gebruikt. Voor deze studie is de vertaalde versie in het Farsi gebruikt. De COTAN (Commissie Testaangelegenheden Nederland) beoordeelt zowel de betrouwbaarheid als de validiteit van de Beck-vragenlijst als voldoende (Evers et al., 2000). Over het algemeen wordt een coëfficiënt a gevonden van .73 tot .92 (Beck et al., 1979). De betrouwbaarheid van de gebruikte versie in dit onderzoek ligt tussen 0.76 en 0.82 met behulp van gangbare normen.

Voor analyses van de gegevens van de BDI zijn genormeerde scores gebruikt. Dit is gedaan om een beter overzicht te krijgen van het niveau van de klachten. Voor de Beck-vragenlijst zijn de volgende categorieën gebruikt: 
Lage depressie $=1$

Gemiddelde depressie $=2$

Hoge depressie $=3$

Zeer hoge depressie $=4$

\section{De Utrechtse Copinglijst (UCL):}

De UCL definieert 7 copingstijlen. Coping is de manier waarop iemand zowel gedragsmatig als cognitief als emotioneel op de aanpassing vereisende omstandigheden reageert. Het betreft een proces dat uit vele afzonderlijke componenten bestaat en dat voortdurend verandert. De copingstijlen zijn verschillend en worden door iedereen verschillend toegepast. De (in)effectiviteit van de copingstijlen heeft vooral te maken met de (in)flexibiliteit en de intensiteit van het toepassen van de stijlen.

De UCL is een 47-items, zelfrapportagevragenlijst met een 4-punts Likert-schaal. De UCL heeft 7 schalen, te weten: actief aanpakken (AC), palliatieve reacties (PAL), vermijden, afwachten (VER), sociale steun zoeken (SOC), passief reactiepatroon (PAS), expressie van gevoelens (EXP) en geruststellende gedachten (GER). COTAN beoordeelt de betrouwbaarheid als onvoldoende en de validiteit van de vragenlijst als voldoende (Evers et al., 2000). Coëfficiënt a wordt gemiddeld tussen 0.67 tot 0.84 berekend (Schreurs et al., 1988). De betrouwbaarheid van subschalen van de gebruikte versie bij onderzoek 1 variëren van 0.71 tot 0.75 .

Voor analyses van de gegevens van de BDI zijn genormeerde scores gebruikt. Dit is gedaan om een beter overzicht te krijgen van het niveau van de klachten. De volgende categorieën zijn gebruikt:

$$
\begin{aligned}
& 1=\text { zeer laag } \\
& 2=\text { laag } \\
& 3=\text { gemiddeld } \\
& 4=\text { hoog } \\
& 5=\text { zeer hoog }
\end{aligned}
$$

\section{De Symptom Klachten Vragenlijst (SCL-90)}

De SCL-90 is een multidimensionele zelfrapportageschaal. De schaal is een 5-punts Likertschaal. Met deze vragenlijst maakt men taxaties van psychiatrische symptomen. SCL-90 wordt zowel in de klinische praktijk als bij wetenschappelijk onderzoek gebruikt.

De SCL-90 brengt het psychisch disfunctioneren in kaart en geeft informatie over 9 specifieke, klinische dimensies, te weten: agorafobie (AGO), angst (ANG), depressie (DEP), somatische klachten (SOM), insufficiëntie van denken en handelen (IN), wantrouwen en interpersoonlijke sensitiviteit (SEN), hostiliteit (HOS), slaapproblemen (SLA), overige vragen (OVER) en psychoneuroticisme (PSNEUR). De COTAN beoordeelt de betrouwbaarheid en de validiteit van de vragenlijst als goed en de normen als onvoldoende (Evers et al., 2000). Coëfficiënt a ligt tussen .80 en 1.00. Gemiddeld is er een a-waarde van 0.90 gevonden (Evers et al., 2000; Arrindell \& Ettema, 1986). De betrouwbaarheid van de subschalen ingevuld door de respondenten van onderzoek 1 variëren van 0.72 tot 0.80 . 
In onderzoek 1 zijn de volgende normscores van SCL-90 gebruikt:

$$
\begin{aligned}
& 1=\text { zeer laag } \\
& 2=\text { laag } \\
& 3=\text { benedengemiddeld } \\
& 4=\text { gemiddeld } \\
& 5=\text { bovengemiddeld } \\
& 6=\text { hoog } \\
& 7=\text { zeer hoog }
\end{aligned}
$$

Dit is gedaan om een beter overzicht te geven van de mate en het niveau van de klachten.

\section{Vragenlijst begeleidingsvariabelen}

De vragenlijst is een zelfontworpen meetinstrument. Voor de constructie is gebruikgemaakt van de originele vragenlijst die door Von Grumbkow \& Ramaekers (2000a) en Ramaekers (2003) ontwikkeld is. De schalen, die betrekking hebben op de variabelen inspraak, vertrouwen en rechtvaardigheid, zijn ontleend aan hun onderzoeken en zijn inhoudelijk aangepast aan de doelgroep van onderzoek 1. De begeleidingsvragenlijst was voor de twee onderzoeksgroepen identiek.

De conceptvragenlijst is vooraf door een aantal Iraniërs ingevuld in verband met duidelijkheid en de tijd die de vragenlijst in beslag zou nemen. Hun opmerkingen zijn verwerkt in de definitieve vragenlijstversie.

De originele vragenlijst bevat 40 items. De respondenten konden aangeven in hoeverre zij het daarmee (on)eens waren.

Voor het beantwoorden van de stellingen werd een schaal gebruikt. De gebruikte schaal is een 5-punts antwoordschaal van het Likert-type, lopend van geheel mee eens tot geheel mee oneens.

\section{De begeleidingsvragenlijst bestaat uit twee onderdelen:}

Deel A gaat over de algemene en demografische kenmerken van de respondenten. Verder werden vragen gesteld over onder andere: de fase van het verblijf, het bezit van een verblijfsvergunning en de positie van respondenten op de arbeidsmarkt.

Deel $\mathrm{B}$ bestaat uit vragen over de waargenomen kansen op positieverbetering en ervaren begeleiding. Dit onderdeel bevat schalen waarmee de afhankelijke variabele kansperceptie en de ervaren begeleiding van de respondenten is vastgesteld.

Hierna volgt een beschrijving van de schalen van de vragenlijst:

\section{De schaal waargenomen kansen op de positieverbetering}

Ik ben ervan uitgegaan dat wil de begeleiding naar integratie effectief zijn, deze voor de respondent tot bepaalde opbrengsten (resultaten) moet leiden. Deze opbrengsten beschouw ik als door de respondent waargenomen kansen. Deze perceptie van kansen 
als afhankelijke variabele is in deze studie onderzocht. Deze kansen zijn inschattingen die de respondent maakt over in welke mate de eigen positie verbetert door de begeleiding die hij meent te krijgen of gekregen heeft.

Door middel van 12 vragen werd nagegaan in welke mate de respondenten menen dat de begeleiding hun kansen vergroot op werk, op het verwerven van betere beroepsvaardigheden, op toename van zelfvertrouwen, op het vergroten van het sociale netwerk en dergelijke. De gebruikte schaal is een 5-punts antwoordschaal van het Likert-type, lopende van geheel mee eens tot geheel mee oneens.

\section{Stellingen over de waargenomen kansen}

1. Door de begeleiding wordt de kans op werk groter dan zonder begeleiding.

2. Door de begeleiding wordt de kans dat mijn lichamelijke gezondheid op peil blijft groter dan zonder begeleiding.

3. Door de begeleiding is de kans dat mijn psychische gezondheid op peil blijft groter dan zonder begeleiding.

4. Door de begeleiding is de kans om mijn financiële situatie te verbeteren groter dan zonder begeleiding.

5. Door de begeleiding is de kans dat ik meer beroepsvaardigheden kan verwerven groter dan zonder begeleiding.

6. Door de begeleiding wordt de kans dat ik meer zelfvertrouwen krijg groter dan zonder begeleiding.

7. Door de begeleiding wordt de kans op meer sociale contacten groter dan zonder begeleiding.

8. Door de begeleiding wordt de kans op werk dat beter aansluit bij mijn persoonlijke wensen en voorkeuren groter dan zonder begeleiding.

9. Door de begeleiding wordt de kans op werkaanbiedingen groter dan zonder begeleiding.

10. Door de begeleiding wordt de kans op een vaste baan groter dan zonder begeleiding.

11. Door de begeleiding is de kans dat ik mijn situatie verbeter groter dan zonder begeleiding.

12. Door de begeleiding is de kans dat ik het verschil tussen Iraanse en Nederlandse cultuur kan overbruggen groter dan zonder begeleiding.

Uit factoranalyse (principale-componentenanalyse) blijkt dat er één factor van deze schaal ten grondslag ligt welke $40 \%$ van de variatie verklaart. Een hoge gemiddelde score op deze schaal betekent dat de respondent voor zichzelf hoge kansen waarneemt op positieverbetering door de begeleiding. Er is een betrouwbaarheidsanalyse gemaakt. Uit deze analyse bleek dat de interne samenhang hoog is (Cronbach's alfa $=0.92$ ). De reacties op de 12 vragen worden opgeteld. 


\section{Schaal inspraak}

De instrumentele inspraak heb ik vastgesteld door respondenten te vragen in welke mate zij invloed kunnen uitoefenen op de begeleiding die ze krijgen en/of ze voldoende op de hoogte zijn gesteld van de mogelijkheden die de begeleiding hun kan bieden.

De niet-instrumentele (persoonlijke) inspraak is vastgesteld door middel van vragen naar de kwaliteit van de relatie met de begeleiders. Respondenten is de vraag voorgelegd of ze in gesprekken met hun begeleiders hun eigen ideeën en gevoelens kunnen uiten en/ of hun begeleider voldoende weet wat er bij de respondenten leeft. De gebruikte schaal is een 5-punts antwoordschaal van het Likert-type van geheel mee eens tot geheel mee oneens.

\section{Stellingen over inspraak}

1. Ik kan veel invloed uitoefenen op de begeleiding.

2. Ik ben in grote mate zelf verantwoordelijk voor het resultaat van de begeleiding.

3. Ik word heel goed op de hoogte gesteld van de mogelijkheden van de begeleiding.

4. Ik kan tijdens de gesprekken met mijn begeleider mijn ideeën en gevoelens uiten.

Uit factoranalyse (principale-componentenanalyse) blijkt dat één factor aan deze schaal ten grondslag ligt welke $48 \%$ van de variatie verklaart. Een hoge gemiddelde score op deze schaal betekent dat de respondenten via inspraak zich betrokken voelen bij de begeleiding en voor zichzelf hoge kansen schatten op positieverbetering door de begeleiding. Er is een betrouwbaarheidsanalyse gemaakt. Uit deze analyse bleek dat de interne samenhang voldoende is (Cronbach's alfa $=0.76$ ). De reacties op 4 vragen worden opgeteld.

\section{Schaal vertrouwen}

Vertrouwen bij de respondenten is vastgesteld door hun vragen te stellen over de werkwijze van de begeleiders en over het begeleidingssysteem.

Over de begeleider is aan respondenten de vraag gesteld in welke mate de respondent vertrouwen heeft in de adviezen van de begeleider en wat deze voor de respondent kan betekenen.

Over de begeleiding werd gevraagd in welke mate er vertrouwen is in de resultaten van de begeleiding en in de wijze waarop deze is opgezet.

De gebruikte schaal is een 5-punts antwoordschaal die van geheel mee eens tot geheel mee oneens loopt.

\section{Stellingen over vertrouwen}

1. Mijn begeleider weet goed wat er bij mij leeft.

2. Ik heb veel vertrouwen in de wijze waarop mijn begeleider mij adviseert.

3. Ik heb veel vertrouwen in wat de begeleider voor mij kan bereiken.

4. Ik heb veel vertrouwen in de resultaten van de begeleiding.

5. Ik heb veel vertrouwen in de wijze waarop de begeleiding is opgezet. 
Uit de factoranalyse (principale-componentenanalyse) blijkt dat er één factor aan deze schaal ten grondslag ligt welke $60 \%$ van de variatie verklaart. Een hoge gemiddelde score op deze schaal betekent dat de respondent een hoge mate van vertrouwen ervaart in de begeleider en in het systeem van begeleiding. Er is een betrouwbaarheidsanalyse gemaakt. Uit analyse blijkt dat de interne samenhang voldoende is (Cronbach's alfa = 0.77). De reacties op 5 vragen worden opgeteld.

\section{Schaal procedurele rechtvaardigheid}

In dit onderzoek is de mate van rechtvaardigheid vastgesteld door de respondenten te vragen naar de verschillende aspecten van de begeleidingsprocedure. Negen stellingen werden geformuleerd en verdeeld over 5 rechtvaardigheidsregels van Leventhal (1980). De stellingen werden geformuleerd naar de meningen van de respondenten over de procedurele rechtvaardigheid bij het systeem van begeleiding en de begeleider. De gebruikte schaal is een 5-punts antwoordschaal van het Likert-type, lopende van geheel mee eens tot geheel mee oneens. Een hoge gemiddelde score op deze schaal betekent dat de respondent de procedure van de begeleiding als fair en eerlijk ervaart.

\section{Stellingen over procedurele rechtvaardigheid}

1. Het systeem van begeleiding bezorgt iedere vluchteling evenveel kansen.

2. Mijn begeleider behandelt iedere vluchteling op dezelfde manier.

3. Het systeem van begeleiding is eerlijk en fair.

4. Over het geheel genomen is de informatie die ik van mijn begeleider krijg/kreeg, zorgvuldig en juist.

5. Mogelijke klachten over de begeleiding worden door het systeem van begeleiding altijd zorgvuldig behandeld.

Uit de factoranalyse blijkt dat er één factor aan deze schaal ten grondslag ligt welke 38\% van de variatie verklaart. De interne consistentie is goed (Cronbach's alfa $=0.88$ ). De reacties op de vragen worden opgeteld.

\section{Conclusie:}

Over het algemeen wordt voor complexe begrippen een minimum alfa van 0.60 als maatstaf genomen (Baarda et al., 2003). Uit het bovenstaande blijkt dat alle vier begeleidingsvariabelen voldoen aan deze eisen en de schalen kunnen als betrouwbaar bestempeld worden.

\subsubsection{Modererende variabelen}

In onderzoek 1 wordt het effect van de modererende variabelen op de waargenomen kansen op positieverbetering getoetst. Deze variabelen heb ik'individuele en psychologische 
variabelen' genoemd. Met individuele variabelen bedoel ik demografische kenmerken (geslacht, leeftijd) en het beschikken over een verblijfsstatus. Een moderator is een kwalitatieve of een kwantitatieve variabele die effect heeft op de richting en/of de sterkte van de relatie tussen predictor(en) en de afhankelijke variabele.

De mate van depressie (gemeten door de BDI), de gehanteerde copingstijl (gemeten door de UCL) en de algemene psychopathologie (gemeten door de SCL-90) van de respondenten heb ik'psychologische variabelen' genoemd.

Er werd gekeken of deze variabelen modererende effecten hebben op de relatie tussen de onafhankelijke begeleidingsvariabele (samengesteld uit de drie begeleidingsvariabelen rechtvaardigheid, vertrouwen, inspraak) en de afhankelijke variabele kansperceptie.

Behalve psychologische factoren, is ook onderzocht of demografische kenmerken van respondenten effect hebben op de relatie tussen de ervaren begeleiding en de kansperceptie van de respondenten. Individuele variabelen zijn de persoonskenmerken van respondenten, namelijk geslacht en leeftijd. Daarnaast is ook het modererende effect van het beschikken over een verblijfsstatus als een individuele variabele onderzocht.

\subsubsection{Vertalingsprotocol}

De geselecteerde meetinstrumenten werden in het Farsi aan de respondenten voorgelegd. De toestemming van de oorspronkelijke auteur voor vertaling van de Utrechtse vragenlijst werd via de Nederlandse uitgever aangevraagd en is verkregen. De BDI en de SCL90 worden ook in Iran gebruikt en zijn daarom niet vertaald.

In eerste instantie heb ik de Utrechtse vragenlijst in het Farsi vertaald. Daarna werden de vragenlijsten door twee andere onafhankelijke vertalers in het Farsi vertaald. Alle vertalers waren vloeiend twee- of drietalig (Farsi, Nederlands en Engels). Nadat de oorspronkelijke vertalingen gereed waren, werden onderlinge meningsverschillen bediscussieerd, waarna een gezamenlijke vertaling werd opgesteld.

De gezamenlijke versie werd door een andere vertaler die ook vloeiend tweetalig was, onafhankelijk terugvertaald naar de oorspronkelijke taal, in dit geval het Nederlands. De originele en de vertaalde versies werden met elkaar vergeleken, waarbij men opnieuw onderlinge tegenstrijdigheden besprak en corrigeerde.

Dit proces werd herhaald tot alle vertalers van mening waren dat de items identiek waren naar inhoud en betekenis.

\subsubsection{Representativiteit}

Er is bewust gestreefd naar heterogeniteit wat de samenstelling van de onderzoeksgroep betreft. Tot de doelgroep behoren respondenten met diverse opleidingsniveaus en leeftijden. In de onderstaande tabel is een overzicht gegeven van de kenmerken van de onderzoeksgroep en de landelijke gegevens over het beleven van de begeleiding qua leeftijd, geslachtsverdeling en het opleidingsniveau.

Met behulp van de Chi-kwadraat-toets is nagegaan of de onderzoeksgroep representatief is vergeleken met een grote representatieve steekproef Iraniërs in Nederland uit 
een CBS-onderzoek (CBS, 2004). De vergelijking betreft vier kenmerken: geslacht, leeftijd, opleidingsniveau en huishoudelijke samenstelling. Op basis van deze vergelijking kan de conclusie worden getrokken dat de representativiteit van de onderzoeksgroep over het algemeen als 'redelijk goed' te benoemen is. Burgerlijke staat en de opleidingsniveaus van de respondenten komen het meest overeen met het grootschalige onderzoek van het CBS. De kenmerken van de onderzoeksgroep van het onderzoek staan in tabel 9.1.

Tabel 9.1 Vergelijking enkele kenmerken van de onderzoeksgroep met het landelijke CBS-onderzoek naar Iraniërs in Nederland in percentages (CBS, 2004)

\begin{tabular}{|l|l|l|}
\hline Kenmerk & $\begin{array}{l}\text { Iraniërs in Nederland } \\
\text { (CBS) }\end{array}$ & $\begin{array}{l}\text { Onderzoeksgroep } \\
\text { Gegevens in percentages }\end{array}$ \\
\hline Aantal & 1000 & 148 \\
Mannen & $57 \%$ & $49 \%$ \\
Vrouwen & $43 \%$ & $51 \%$ \\
\hline Opleidingsniveau (\%) & \multicolumn{2}{|l|}{} \\
\hline Lagere school & $10 \%$ & $9.0 \%$ \\
Middelbare school, VBO, MBO & $57 \%$ & $58 \%$ \\
HBO/WO & $31 \%$ & $33 \%$ \\
Geen diploma & $2.0 \%$ & $0.0 \%$ \\
\hline Leeftijd (\%) & \multicolumn{2}{|l|}{} \\
\hline 0-9 & $13 \%$ & $0.0 \%$ \\
$10-19$ & $15 \%$ & $1.0 \%$ \\
$20-29$ & $26 \%$ & $21 \%$ \\
$30-39$ & $19 \%$ & $32 \%$ \\
$40-49$ & $10 \%$ & $38 \%$ \\
50-plus & $28 \%$ & $8.0 \%$ \\
\hline Burgerlijke staat (\%) & $23 \%$ & $32 \%$ \\
\hline Alleenstaand & $30 \%$ & $46 \%$ \\
Getrouwd/Samenwonend & $57 \%$ & $22 \%$ \\
met kinderen & \multicolumn{2}{|l}{} \\
Eenouderhuishouden & \multicolumn{2}{|l|}{} \\
\hline
\end{tabular}




\subsubsection{Validiteit en betrouwbaarheid}

De kwaliteit van ieder onderzoek wordt bepaald door de mate van betrouwbaarheid en validiteit (Swanborn, 1987; Van der Zwaan, 1990; Van Buuren et al., 1990; Den Hertog \& Van Sluijs, 1995).

Validiteit wil zeggen dat gemeten wordt wat beoogd wordt te meten. Validiteit bepaalt in hoeverre het onderzoek vrij is van systematische fouten.

Om de vraag te kunnen beantwoorden of onderzoek 1 voldoende validiteit heeft, is het belangrijk om voldoende informatie te hebben over de interne validiteit, betrouwbaarheid en constructvaliditeit.

De constructvaliditeit, die ook inhoudsvaliditeit of begripsvaliditeit genoemd wordt, gaat ervan uit dat het meetinstrument meet wat men voor ogen heeft. Swanborn (1987) formuleert het begrip constructvaliditeit als volgt:'Dit begrip heeft betrekking op de vraag in hoeverre de vertaling van de theorie naar de praktijk (de operationalisatie) geslaagd is. Met andere woorden: is het kenmerk zoals bepaald, het concrete verschijnsel, een goede afspiegeling van het theoretische concept en het kenmerk zoals bedoeld is.'

Het is voor de inhoudsvaliditeit van groot belang dat de ondervraagden de vragen van de vragenlijst goed begrijpen. Om de inhoudsvaliditeit van de begeleidingsvragenlijst te verhogen, is de vragenlijst vooraf aan een aantal Iraniërs voorgelegd. Op basis van hun opmerkingen heeft een aantal aanpassingen plaatsgevonden om de vragenlijst zo goed mogelijk begrijpelijk te maken voor de respondenten. Deze heb ik mondeling gedaan en de opmerkingen zijn verder genoteerd en later verwerkt tijdens de aanpassing van de vragenlijst.

De betrouwbaarheid van een onderzoek geeft aan in hoeverre het onderzoek vrij is van toevallige fouten. Een betrouwbaar onderzoek is repliceerbaar, dat wil zeggen dat herhaling van het onderzoek onder overeenkomstige omstandigheden leidt tot dezelfde uitkomsten.

De Cronbach's alpha's van de schalen bepalen ook in dit onderzoek de mate van betrouwbaarheid. Voor alle schalen zijn (redelijk) hoge Cronbach's alpha's gevonden.

\subsubsection{Data-analyses}

Voor de toetsing van de hypothesen die betrekking hebben op de percepties van respondenten van de begeleidingsvariabelen, met name procedurele rechtvaardigheid, inspraak en vertrouwen, werd gebruikgemaakt van de t-toets, regressie- en variantieanalysemethode. In de analyses zijn verder de effecten van de moderatoren onderzocht.

Gezien het feit dat het gebruik van de variantieanalyse afhankelijk is van een aantal voorwaarden, is eerst onderzocht in hoeverre aan die eisen is voldaan.

Hieronder is een beschrijving gegeven van onze datacontrole.

\section{Voorwaarden met betrekking tot datacontrole}

Voorafgaand zijn er enkele toetsen ter controle verricht. Dit heeft te maken met de drie voorwaarden die gesteld zijn ten behoeve van het verrichten van regressie- en variantie- 
analyses. Het is belangrijk om de data te controleren met betrekking tot de volgende drie voorwaarden:

- Controle met betrekking tot de assumpties

- De mate van selectieve uitval

- Aanwezigheid van extreme scores

\subsubsection{Datacontrole}

Voordat ik de variantieanalyse heb uitgevoerd, werden de data gecontroleerd op de volgende aspecten: meetniveau, lineaire relatie tussen afhankelijke variabele kansperceptie en onafhankelijke variabelen, multicollineariteit en homoscedasticiteittest. Daarnaast is nagegaan of er extreme scores bestaan en/of er sprake is van een bepaalde mate van selectieve uitval.

\subsubsection{Meetniveau}

Belangrijke veronderstellingen bij regressieanalyse betreft het meetniveau van de variabelen en de vorm van het verband. Voor wat betreft het meetniveau wordt verondersteld dat zowel het criterium (afhankelijke variabele) als de predictoren (onafhankelijke variabelen) interval of ratio zijn. De dummyvariabelen vormen hierop een uitzondering (Huizingh, 2006).

Het meetniveau van de verschillende zelfgemaakte schalen is bij benadering (quasi-) interval. Dat geldt ook voor de drie standaardvragenlijsten (SCL-90, BDI en UCL). Variabelen geslacht en verblijfsvergunning hebben een nominaal meetniveau. Gemiddelde en spreiding van alle respondenten staan vermeld in bijlage 1, tabel 1.

Om een beter overzicht te geven van de spreiding van de leeftijd van respondenten is de variabele leeftijd in vijf klassen van negen jaar verdeeld.

\subsubsection{Verdeling (normaliteit), selectieve uitval}

Het andere vereiste betreft de vorm van het verband. Aangenomen wordt dat de residuen normaal verdeeld zijn. Naarmate het aantal observaties in verhouding tot het aantal predictoren groter is, is het lineaire regressiemodel meer robuust tegen afwijkingen van deze assumpties. Ten aanzien van de predictorvariabelen zijn er geen assumpties noodzakelijk. Wel impliceert het gebruik van lineaire regressie dat de predictoren een lineaire en geen curvilineaire relatie met de criteriumvariabele hebben (Van Knippenberg \& Siero, 2000; Miles \& Shelvin, 2001).

Voor dit onderzoek is via een spreidingsdiagram nagegaan of de verbanden lineair zijn. Door het gebruikmaken van de correlatiecoëfficiënt is eerst de samenhang tussen het criterium (kans) met predictorvariabelen in kaart gebracht. Voor de begeleidingsvariabelen vertrouwen, inspraak en een rechtvaardige procedure is nagegaan of de verdeling van de waarden een normale verdeling heeft: een verdeling die symmetrisch en klokvormig is. Er zijn geen vreemde hoge of lage uitschieters gevonden die in de richting van een asymmetrische vorm wijzen. Er is nagegaan of elke variabele bij benadering normaal is 
verdeeld. Hiervoor werd gekeken naar de scheefheid (skewness) en de steilheid (kurtosis) van de univariate analyses. Deze lagen binnen de normen. Er is voldaan aan de eisen van de normaliteit.

Om na te kunnen gaan of er sprake is van selectieve uitval, is voor elke variabele onderzocht of de groep die een ontbrekende score heeft tot een specifieke groep behoort. Om te voorkomen dat deze specifieke groep van respondenten buiten de analyse valt en om de totale omvang van de groep uitvallers te beperken, is de methode toegepast die Cohen \& Cohen (1983) hebben geïntroduceerd. Deze methode houdt het volgende in: aan elke respondent van wie de informatie op een bepaalde variabele ontbreekt, is de gemiddelde score toegekend. Deze gemiddelde score is berekend over de scores op die variabele van alle overige respondenten. Vervolgens is er een nieuwe variabele gemaakt met twee categorieën, bestaande uit 0 en de respondenten die oorspronkelijk een geldige score hebben. Respondenten hebben een geldige score als zij op alle variabelen een respons hebben gegeven. Respondenten die oorspronkelijk een ontbrekende score hebben, krijgen een ongeldige score. Als de dichotome variabele een significante invloed heeft op de afhankelijke kansmeting, betekent dit dat degenen die oorspronkelijk geen geldige score hebben, verschillen van degenen die oorspronkelijk wel een geldige score hebben. Deze methode is uitgevoerd voor alle onafhankelijke begeleidingsvariabelen en de psychologische variabelen (moderatoren). Op grond van onze test mogen we concluderen dat er geen selectieve uitval is waardoor we de categorie van respondenten zonder geldige score uit de analyse laten.

De Vocht (2005) adviseert een grens van 3 standaarddeviaties te hanteren. De residuen dienen ook normaal verdeeld te zijn. Dit betekent dat $95 \%$ van de respondenten binnen 3 standaarddeviaties van het gemiddelde (de lijn) moeten liggen. Gevallen met zeer grote gestandaardiseerde residuen $(>3$ ) kunnen vaak beter buiten het model worden gelaten.

\subsubsection{Extreme scores}

Het is aanbevolen om na te gaan of er extreme scores optreden. Dit heeft te maken met scores die in extreme mate de richting van de regressiecoëfficiënt kunnen beïnvloeden.

Deze scores kunnen van grote invloed zijn op de regressie-uitkomsten. Het probleem van de'outliers' is vast te stellen door de residuen (het verschil tussen werkelijke en geschatte criteriumscores) te standaardiseren. Gestandaardiseerde residuen met een absolute waarde groter dan 3 kunnen worden beschouwd als 'outliers'. Het is belangrijk om vast te stellen waarom deze scores optreden en die ook vervolgens te elimineren. Cases met zeer grote gestandaardiseerde residuen kunnen beter buiten de analyse worden gelaten. Om een regressieanalyse te kunnen uitvoeren, moeten de residuen normaal verdeeld zijn, met een gemiddelde van 0 en een constante variantie (Miles, 2005).

$\mathrm{Er}$ is nagegaan of er extreme scores aanwezig zijn (outliers). Deze analyse is verricht om te voorkomen dat de richting van analyse beïnvloed wordt.

Om na te gaan of er sprake is van extreme scores, moet voor elke variabele onderzocht worden of er een groep bestaat die een extreme waarde/score heeft. Vervolgens moet 
worden nagegaan of deze scores tot een specifieke groep of systeem behoren. Bij analyse van de gegevens zijn er geen extreme scores gevonden waardoor de richting van analyses zouden kunnen veranderen.

\subsubsection{Lineaire samenhang}

Lineariteit is eigenlijk niets anders dan een 'schattingsprobleem'. Met Scatter Plots is nagegaan of er lineaire samenhang bestaat tussen de afhankelijke $Y$ (kansinschatting) en onafhankelijke $X$ (tevredenheid en moderatoren). De verbanden die zijn aangetroffen waren niet afwijkend van lineariteit.

\subsubsection{Multicollineariteit}

Er bestaan situaties waarin de predictoren onderling substantieel correleren. In het geval dat de scores op twee predictoren in sterke mate correleren, spreken we van multicollineariteit.

Bij regressieanalyse kan multicollineariteit optreden wanneer de onafhankelijke variabelen onderling sterk correleren: het effect op de afhankelijke variabele $Y$ (variabele kans) wordt dan arbitrair. Immers, beide onafhankelijke variabelen 'verklaren' vrijwel dezelfde variatie in Y. Er is geen absolute regel wanneer multicollineariteit 'ernstig' wordt. De oplossing is om één van de twee onderling correlerende onafhankelijke variabelen uit de analyse te verwijderen.

Omdat een aantal regressieanalyses in deze studie is uitgevoerd, is nagegaan of er sprake is van multicollineariteit. Bij de regressieanalyse is een multicollineariteitdiagnose uitgevoerd waaruit bleek dat de condition index enkele keren de 15 passeert maar lager is dan 30. Op basis hiervan kan worden vastgesteld dat multicollineariteit geen probleem is (De Vocht, 2005). De Vocht (2005) stelt dat multicollineariteit tot stand komt als de onafhankelijke variabelen in een en dezelfde vergelijking onderling erg hoog correleren. De Vocht stelt dat indien er correlaties van $\mathrm{R} \geq 0.80$ voorkomen, het aan te raden is om één van de beide onafhankelijke variabelen buiten het model te laten.

\subsubsection{Homoscedasticiteit}

Homoscedasticiteit wil zeggen dat de standaardafwijking van de modelafwijkingen voor iedere waarde van $Y$ dezelfde waarde heeft. Het omgekeerde wordt heteroscedasticiteit genoemd.

De nulhypothese, dit wil zeggen dat de modelafwijkingen homoscedast zijn, kan op diverse manieren worden getoetst. Een 'quick and dirty methode' is de residuen in twee gelijke groepen te verdelen en in beide groepen de steekproefvariantie te berekenen. De nulhypothese $\mathrm{H0}:=1$ wordt getoetst met de F-toets tegen het tweezijdige alternatief H1: \#1.

Uit de analyses blijkt dat verdere controle en aanpassingen wat de data van deze studie betreft, niet nodig zijn.

Bij het toetsen met de modellen zijn de covariabelen leeftijd, geslacht en het bezit van status meegenomen. 


\subsection{Onderzoek 2: diepte-interviews}

De tweede studie van dit onderzoek is een diepte-interview dat gehouden is met twintig respondenten. Deze onderzoeksgroep bestaat in totaal uit tien asielzoekers en tien (ex-) vluchtelingen. Met deze twintig diepte-interviews wordt geprobeerd vast te stellen welke subjectieve beleving de respondenten met de begeleiding hebben en hoe ze hun kansen op het slagen in de Nederlandse samenleving percipiëren.

In paragraaf 9.2.2 wordt de procedure van het onderzoek uitgelegd. Vervolgens worden de kenmerken van de onderzoeksgroep, de methodologische verantwoording en de positionering van de onderzoekster beschreven. In paragraaf 9.2.9 operationaliseer ik de vraagstellingen door middel van een topiclijst.

Ten slotte worden in paragraaf 9.2.10 de uitgangspunten van de analyse toegelicht en passeren de aspecten van de topiclijst de revue.

\subsubsection{Diepte-interviews}

Onderzoek 2 bestaat uit diepte-interviews. Door het afnemen van de diepte-interviews wordt ernaar gestreefd een beeld te geven van de complexiteit van de bestaande werkelijkheid ter aanvulling van onderzoek 1.

Volgens Den Hertog (1991) en De Leede (1997) dienen zowel de gebeurtenissen uit het verleden als de verschijnselen van het heden geplaatst te worden in een historische context.

In deze studie is naast het verleden ook gekeken is naar verschijnselen uit de hedendaagse werkelijkheid en deze worden geplaatst in een historische context. Deze interviews gaan mede over veranderingen of processen. Het gaat niet alleen om de beschrijving van de situaties op meerdere tijdstippen zelf, maar ook om de analyse van de tussenliggende processen die deze tijdstippen of situaties verbinden.

Bij het beschrijven van de gevallen is er rekening mee gehouden dat een sociale werkelijkheid altijd in een context ontstaat waarbinnen mensen zich op een bepaald moment bevinden en waarbinnen ze handelen. Het gaat om een momentopname die subjectief wordt beleefd (Braster, 2000).

In onderzoek 2 is ernaar gestreefd om een beeld te geven van de gezamenlijke of gedeelde beleving (intersubjectiviteit) van de respondenten. Het uitgangspunt van dit onderzoek en de probleemstelling zijn al eerder in de voorafgaande hoofdstukken beschreven. De wisselwerking tussen de individuele en psychologische factoren (interne factoren) enerzijds, en de begeleidingsfactoren (externe factoren) anderzijds, zijn als centraal punt uitgewerkt bij het samenstellen en het uitvoeren van onderzoek 2 .

Mijn intentie was om erachter te komen welke rol deze twee groepsfactoren en hun onderlinge interacties spelen bij het waarnemen van de kansen in de Nederlandse samenleving. Als onderzoeksmethode is gekozen voor een diepte-interview dat gebaseerd is op een topiclijst. De analyses van alle vragenlijsten die bij het kwantitatieve onderzoek 1 gebruikt zijn en de probleemstelling hebben richting gegeven aan de samenstelling van de vragen van de interviews. 


\subsubsection{Procedure}

Na een lange voorbereidingsfase heb ik in 2006-2007 twintig interviews gehouden met tien asielzoekers en tien (ex-)vluchtelingen, en deze vervolgens geanalyseerd. De respondenten hadden de vragenlijst met de vier schalen al eerder ingevuld. Elk interview duurde ongeveer 3 uur. De vragen zijn opgesteld met de nadruk op variabelen die van belang zijn voor deze studie.

Om de respondenten een helder beeld te geven over het onderzoek, besprak ik het doel van het onderzoek, de tijd die het interview in beslag zou nemen en de geheimhouding van de gegevens. Om de privacy van respondenten te waarborgen en het interview ongestoord te laten plaatsvinden, zijn de interviews onder vier ogen gehouden.

In het najaar van 2005 heb ik op basis van een randomsteekproef tachtig respondenten geselecteerd voor het interview. De respondenten zijn zowel persoonlijk als telefonisch benaderd. Uiteindelijk hebben twintig respondenten hun medewerking toegezegd. Kandidaten die niet hebben deelgenomen aan het interview, hebben gezegd dat ze geen tijd en/of interesse hebben.

De interviews met asielzoekers hebben in drie azc's plaatsgevonden: in Leusden, in Amersfoort en in Doorn. Van twee asielzoekers die in een COA-huis woonachtig waren, heb ik de interviews in een andere plaats afgenomen. De interviews zijn opgenomen met een cassetterecorder en daarnaast zijn er tijdens de interviews aantekeningen gemaakt. ledere asielzoeker die aan het interview deelnam, kreeg 15 euro betaald bij wijze van dank en als onkostenvergoeding voor de afgestane tijd.

Alle interviews zijn in het Farsi afgenomen, omdat het voor de respondenten gemakkelijker was in hun moedertaal hun emoties en gevoelens te uiten. Mijn positie als een Iraanse (ex-)vluchtelinge heeft een vertrouwensband gecreëerd. Vooral de groep asielzoekers heeft hier veel waarde aan gehecht. Bijna iedere asielzoeker/asielzoekster benadrukte dat men de hoop had door het vertellen van zijn/haar verhaal meer aandacht te kunnen krijgen voor de moeilijke situatie waarin men zich bevond. Ik heb nadrukkelijk aangegeven dat dit onderzoek geen enkele invloed heeft op hun persoonlijke positie ten opzichte van hun asielprocedure. Over het algemeen was men zich hiervan bewust. Dat neemt niet weg dat het mogelijk is dat de respondenten een boodschap hebben willen afgeven aan degenen die de resultaten van dit onderzoek onder ogen krijgen.

Nadat een inleiding is gehouden, is een aantal algemene vragen gesteld over persoonsgegevens (leeftijd, opleidingsniveau, duur van het verblijf enzovoort). Vervolgens zijn de open vragen gesteld. Bij het stellen van de vragen over de ervaren begeleiding werd de nadruk gelegd op de subjectieve beleving van de respondenten, dus op hun persoonlijke en specifieke ervaring. Het gaat immers om de eigen beleving en het eigen verhaal van de respondenten.

Begeleiding beperkt zich in deze studie niet tot de formele begeleiding. Hoewel deze vorm van begeleiding in het onderzoek centraal staat, hebben de respondenten in de praktijk veel ervaring gehad met informele begeleiding. 


\subsubsection{Kenmerken van de onderzoeksgroep}

Twintig respondenten hebben meegedaan aan het onderzoek. De onderzoeksgroep bestond uit twee groepen asielzoekers en (ex-)vluchtelingen. De groep (ex-)vluchtelingen is in het bezit van een permanente verblijfsvergunning of in het bezit van de Nederlandse nationaliteit. Asielzoekers die in het onderzoek hebben meegedaan, waren voor een deel uitgeprocedeerd en voor een deel woonachtig in azc's in afwachting van hun verblijfsvergunning.

Ik heb een poging gedaan om respondenten te selecteren die varieerden qua leeftijd, opleiding en verblijfsduur. Het opleidingsniveau van de respondenten varieerde van lagere school tot universitaire studie.

Een overzicht van de kenmerken van de respondenten staat in tabel 9.2.

\subsubsection{Methodologische verantwoording van onderzoek 2}

Om de perceptie van alle knelpunten en mogelijkheden van het systeem van begeleiding te kunnen ordenen, heb ik gebruikgemaakt van een analysekader. Dit kader is ontleend aan het schematische overzicht van Baarda et al. (2001).

Dit schematische overzicht houdt in dat er stapsgewijs volgens een cyclisch-iteratief proces een integratie plaatsvindt tussen dataverzameling en data-analyse.

Bij het opstellen van de topiclijst ben ik ervan uitgegaan dat de waargenomen kans een subjectieve aangelegenheid is. Het besef van de kansen ontwikkelt zich binnen een context waar de asielzoekers en vluchtelingen zich op bepaalde momenten bevinden.

In Nederland, als een in vergelijking met Iran meer geïndividualiseerd land, wordt van mensen verwacht dat ze hun eigen analyse van hun situatie geven. Ze worden bovendien verantwoordelijk gehouden voor hun eigen keuzen en handelingen. Volgens Coenen (1987) kunnen de respondenten van een onderzoek opgevat worden als competente acteurs in hun eigen leven. Volgens Coenen-Hanegraaf et al. (2000) is de kennisproductie niet voorbehouden aan sociale wetenschappers, maar is dat dagelijkse praktijk. Als onderzoekster had ik de theoretische kennis over het onderwerp van dit onderzoek. De geïnterviewden hadden hun eigen visie en persoonlijke mening over het onderwerp die impliciet en expliciet zijn onderbouwd. Er is volgens mij sprake van interactie tussen twee competente partijen die elkaar over en weer beïnvloeden. Daarom worden in dit onderzoek de interviews afgenomen in de vorm van een discussie.

Door het gebruiken van dezelfde taal, zich openstellen voor de kritieken en door het stellen van open vragen is geprobeerd een veilige en betrouwbare sfeer voor de respondenten te creëren. Het creëren van een betrouwbare en veilige sfeer is vooral tijdens het interview met de asielzoekers van belang. Asielzoekers bevinden zich in een onzekere en onveilige situatie. Deze onzekerheid werd versterkt door het beleid (2003-2004) om het uitzettingsbeleid te verscherpen. De dreiging om uitgezet te worden heeft voor extra stress, onzekerheid en wantrouwen gezorgd. Dit aspect moest lopende het onderzoek bijzondere aandacht krijgen. 
Tabel 9.2 Algemene gegevens van de respondenten

\begin{tabular}{|c|c|c|c|c|c|c|c|}
\hline Respondent & Status & Leeftijd & Geslacht & Opl/Iran & Opl/Ned & Burg.st & Werk \\
\hline 1 & 1 & 60 & 1 & 5 & 3 & 3 & 1 \\
\hline 2 & 1 & 48 & 2 & 4 & 3 & 2 & 2 \\
\hline 3 & 1 & 49 & 2 & 5 & 5 & 2 & 1 \\
\hline 4 & 1 & 26 & 1 & 1 & - & 1 & 1 \\
\hline 5 & 1 & 23 & 2 & 1 & - & 1 & 1 \\
\hline 6 & 1 & 37 & 1 & 2 & 3 & 1 & 1 \\
\hline 7 & 1 & 50 & 1 & 2 & 3 & 2 & 2 \\
\hline 8 & 1 & 34 & 2 & 2 & 3 & 1 & 2 \\
\hline 9 & 1 & 41 & 2 & 2 & 2 & 4 & 1 \\
\hline 10 & 1 & 33 & 1 & 2 & 2 & 2 & 2 \\
\hline 11 & 2 & 34 & 1 & 5 & - & 2 & 2 \\
\hline 12 & 2 & 32 & 2 & 5 & - & 2 & 2 \\
\hline 13 & 2 & 37 & 2 & 2 & 2 & 2 & 2 \\
\hline 14 & 2 & 42 & 1 & 2 & 2 & 1 & 2 \\
\hline 15 & 2 & 27 & 2 & 2 & 2 & 1 & 2 \\
\hline 16 & 2 & 48 & 1 & 2 & 2 & 4 & 2 \\
\hline 17 & 2 & 36 & 1 & 5 & - & 3 & 2 \\
\hline 18 & 2 & 40 & 1 & 2 & 2 & 4 & 2 \\
\hline 19 & 2 & 45 & 2 & 1 & 4 & 1 & 2 \\
\hline 20 & 2 & 25 & 2 & 1 & - & 3 & 1 \\
\hline
\end{tabular}

Verblijfsvergunning (status): $1=j a, 2=$ geen

Geslacht: $1=$ man, 2 = vrouw

Opleiding in Iran: $1=$ lagere school, $2=$ middelbare school, $3=M B O, 4=H B O, 5=W O$

Opleiding in Nederland: - = bezig, $1=$ lagere school, $2=$ middelbare school, $3=\mathrm{MBO}, 4=\mathrm{HBO}$,

$5=$ WO

Burgerlijke staat: 1 = alleenstaand, 2 = getrouwd, 3 = gescheiden, 4 = samenwonend

Werk: $1=$ ja, 2 = nee 


\subsubsection{Positionering van de onderzoekster}

Een belangrijk aspect van dit onderzoek is mijn positie als onderzoekster en mijn persoonlijke betrokkenheid bij de respondenten. Mijn positie had een positieve uitwerking, maar hield ook risico's in. Als een risicofactor kan ik het verschijnsel 'vanzelfsprekendheid' benoemen. Dit houdt in dat de respondenten over meer kennis en informatie beschikken dan zij verwoorden, omdat zij denken dat ik als hun landgenoot die kennis al heb. Ik heb deze kwestie bij de aanvang van de interviews met respondenten besproken en daardoor kon ik dit risico (hopelijk) zo veel mogelijk beperken.

Mijn positie als een hoogopgeleide en Farsi-sprekende onderzoekster heeft voor- en nadelen voor dit onderzoek.

Als voordelen kunnen we denken aan de volgende aspecten:

- Onderzoekster spreekt dezelfde taal als de respondenten. Dit aspect leidt tot een betere communicatie die vooral van belang is voor de emotionele uitingen van de respondenten.

- Onderzoekster heeft kennis van de achtergrond en de cultuur van respondenten.

- Onderzoekster heeft zelf als (ex-)vluchtelinge de asielprocedure doorgemaakt en kan zich goed inleven in de situatie van de respondenten.

Als nadelen kunnen we denken aan de volgende aspecten:

- Onderzoekster is emotioneel betrokken bij het onderwerp en de onderzoeksgroep waardoor de objectiviteit in gevaar kan komen.

- Onderzoekster heeft theoretische kennis over het onderwerp waardoor het risico bestaat dat 'gelijkwaardigheid' in het geding komt en het verschijnsel van 'vanzelfsprekendheid' kan optreden.

- Onderzoekster heeft in de ogen van de respondenten een succesvolle integratie doorgemaakt. Respondenten zullen zich vergelijken met onderzoekster. Er zijn dan drie situaties denkbaar:
A. de respondent kan zich minder en achtergesteld voelen.
B. de respondent kan de afstand tot de onderzoekster wel overbruggen of zich gelijk- waardig voelen.
C. de respondent kan zich hoger voelen dan de onderzoekster.

Om deze mogelijke processen te overbruggen en een evenwichtige, gelijkwaardige interactie te stimuleren, is ervoor gekozen om een interpersoonlijk model toe te passen. Hieronder treft u een korte beschrijving van het interpersoonlijke model van Leary dat is toegepast (Leary, 1957). 


\subsubsection{Het interpersoonlijke model van Leary}

In de jaren vijftig beschreef Leary (1957) in zijn zogenaamde Roos hoe interactiepatronen tussen therapeuten en cliënten kunnen ontstaan. Het model dat vooral bekend is als de Roos van Leary, is later uitgebreid door Kiesler (1983) en wordt regelmatig gebruikt in de huidige klinische praktijk.

Leary's model gaat ervan uit dat mensen voorkeur hebben voor een bepaalde positie die zij innemen in hun interpersoonlijke contacten en omgang. De voorkeur die ze hebben, heeft invloed op de positie die de gesprekpartner inneemt.

Volgens Kiesler (1983) en Leary (1957) worden relaties bepaald door twee dimensies: affiliatie en controle. Affiliatie heeft betrekking op de mate waarin sprake is van haat dan wel van liefde, van vriendschap dan wel van vijandigheid, van samen willen zijn dan wel van afstand willen houden. Controle gaat over de mate waarin sprake is van dominantie dan wel van submissiviteit, van hoge dan wel van lage status, van initiatieven nemen dan wel van volgen.

Grofweg bestaat de Roos van Leary dus uit twee onafhankelijke dimensies: boven-onder en tegen-samen. Boven verwijst naar een dominante opstelling, onder verwijst naar een submissieve positie, tegen verwijst naar oppositie en samen naar een op samenwerking gerichte opstelling (zie figuur 9.3, p.114).

Samengevat zijn de twee dimensies in interacties volgens het model:

De twee posities boven en onder zijn complementair. Dit betekent dat wanneer een van beiden de bovenpositie inneemt, de ander wordt gestimuleerd de onderpositie te kiezen en andersom.

De posities tegen en samen zijn symmetrisch, dat wil zeggen dat wanneer een van beiden de tegenpositie inneemt, de ander wordt gestimuleerd dezelfde positie te kiezen, terwijl een keuze voor de samenpositie door de een, de ander stimuleert eveneens deze positie in te nemen.

Volgens het model ontstaan problemen in interpersoonlijke contacten wanneer een van beiden de relatiedefiniëring waartoe hij of zij wordt uitgenodigd, niet accepteert. Wanneer beiden bijvoorbeeld dominant willen zijn, dreigt een machtsstrijd. In psychologisch opzicht gezonde personen kunnen relatief gemakkelijk wisselen van positie.

Door de moeilijke positie waarin vooral asielzoekers zich bevinden, was de interactie tijdens de interviews niet altijd eenvoudig. Door het innemen van een 'onder-samen'-positie heb ik geprobeerd de respondenten voldoende ruimte en vrijheid te geven om hun mening openlijk met mij te bespreken. Een accepterende en nieuwsgierige houding heeft me geholpen om zo nodig door te vragen.

Het bewaren van een wetenschappelijke houding ervoer ik als een moeilijk punt tijdens de interviews. 
Figuur 9.3 Interactiepatronen op basis van de twee dimensies van Leary: affiliatie (tegen-samen) en controle (boven-onder). Ontleend aan Leary (1957)

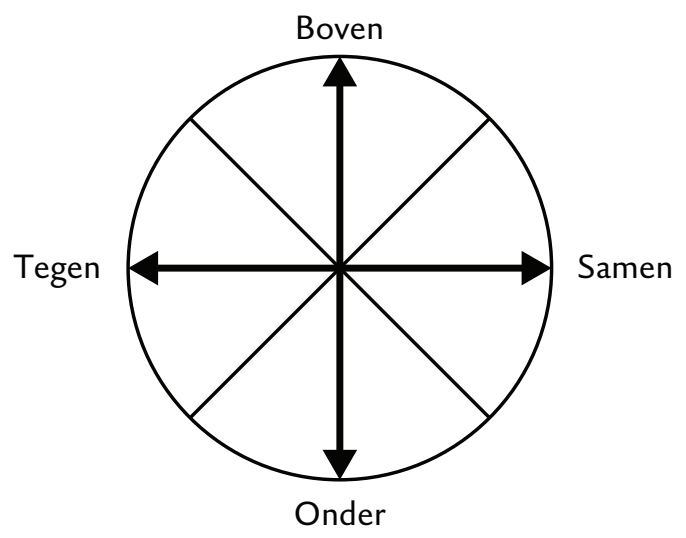

VEREENVOUDIGDE ROOS VAN LEARY

\subsubsection{Voorkomen van vertekening}

Emans (1990) geeft een aantal aanwijzingen om vertekening tijdens het afnemen van interviews te vermijden en de objectiviteit te verhogen. Emans verstaat onder objectiviteit de tegenhanger van subjectiviteit, dat is het verschijnsel dat gegevens door tussenkomst van mensen vertekend worden. Volgens Emans (1990) zijn er tijdens de totstandkoming van een interview drie momenten waarop die vertekening kan plaatsvinden:

- Bij de vormgeving van de situatie.

- Bij de verwoording van de cognities van de respondenten.

- Bij het vastleggen van de antwoorden.

Om vertekening tegen te houden, is gekozen voor een stapsgewijze situatiecontrole volgens de schematische werkwijze van Baarda et al. (2001). Bij de eerste stap heb ik getracht de standaardsituatie te waarborgen door onder andere de geïnterviewde op het gemak te stellen, een duidelijke inleiding te geven over het doel van het onderzoek, het interview onder vier ogen te houden en nauwkeurige aantekeningen te maken.

Bij de tweede stap heb ik getracht een standaardevaluatie te maken van alle gegeven antwoorden. Alle interviews zijn afgenomen in de vorm van een discussie en er werd steeds doorgevraagd naar de beleving en de betekenisgeving. Daarnaast is nagegaan of de geïnterviewde de vragen volledig en correct heeft begrepen en vervolgens de antwoorden goed en compleet heeft gedefinieerd.

Bij de derde stap heb ik geprobeerd om mij te onthouden van het geven van inhoudelijke interpretaties. Dit houdt in dat ik bewust gekozen heb voor een neutrale opstelling. Steeds zijn de feitelijke uitspraken in kaart gebracht. 


\subsubsection{Representativiteit en generaliseerbaarheid}

De vraag of materiaal geschikt is voor een bepaald onderzoek hangt vooral af van een oordeel over de representativiteit ervan. Het gaat om de vraag of de onderzoeksresultaten zijn door te trekken naar de gehele populatie. Daarbij is de vraag aan de orde in hoeverre de bevindingen extern valide zijn. Het verzamelde materiaal dient in voldoende mate de eigenschappen van het uiteindelijke analytische object te representeren.

Baarda et al. (2001) geven de volgende beschrijving van representativiteit: 'Als je een voldoende grote steekproef trekt, krijg je een resultaat dat in principe niet veel afwijkt van de resultaten die je gevonden had als je de gehele doelgroep zou benaderen.' Het is de bedoeling dat de resultaten die in de steekproef gevonden worden tevens van toepassing zijn op de populatie. Dat betekent dat de steekproef dezelfde kenmerken zou moeten hebben als de populatie.

De mate van representativiteit kan gecontroleerd worden door te kijken hoe de bekende kenmerken er in het onderzoek uitzien, en zo nodig correcties toe te passen. Representativiteit en generaliseerbaarheid liggen in feite in elkaars verlengde. Om te weten of de deelnemers een goede afspiegeling zijn van de gehele populatie, bijvoorbeeld qua leeftijd, opleiding en sekse, heb ik informatie verzameld over de demografische gegevens van de populatie Iraanse asielzoekers en vluchtelingen in Nederland. Deze gegevens zijn weergegeven in tabellen 9.1 (p. 103) en 9.2 (p. 111). Uit deze gegevens valt af te leiden dat er geen grote verschillen bestaan wat betreft leeftijd, geslacht en opleiding tussen de onderzoeksgroep en de landelijke gegevens. Dit zou gemakkelijk het idee kunnen geven dat deze studie een redelijk goede representativiteit heeft. In dit verband wil ik wijzen op het onderscheid dat Yin (1989) maakt tussen statistische en analytische generaliseerbaarheid. Wat dit onderzoek betreft, gaat het om de analytische generaliseerbaarheid. De resultaten worden gegeneraliseerd naar de theorie. Daarbij maak ik een vergelijking tussen de gevallen. Deze gevallen moeten gelijke resultaten opleveren. Een voorwaarde voor een theoretische replicatie is dat het theoretische model voldoende en rijk is uitgewerkt. De kracht van de meervoudige casestudies zit niet in een versterking van de conclusies door een grotere steekproef, maar in de mogelijkheid door replicatie de theorie te veralgemeniseren (Yin, 1989; Miles \& Huberman, 1994).

\subsubsection{Betrouwbaarheid}

Het begrip betrouwbaarheid beschrijft de nauwkeurigheid van de meting. Een meting is betrouwbaar als de uitkomsten bij herhaling van de meting binnen een bepaalde periode hetzelfde blijken te zijn (Baarda et al., 2001; Kirk \& Miller, 1986; Nievaard, 1990; Goetz \& LeCompte, 1984). Er is wel een onderscheid gemaakt tussen kwalitatief en kwantitatief onderzoek wat de mate van betrouwbaarheid betreft. In kwalitatief onderzoek is de onderzoeker zelf ook een onderzoeksinstrument. Dit betekent dat herhaalbaarheid moeilijk is. Daarom wordt bij kwalitatief onderzoek in plaats van herhaalbaarheid de term 'intersubjectieve navolgbaarheid' gehanteerd. Smaling (1987) gebruikt termen als navolgbaarheid en geloofwaardigheid. Daarmee bedoelt hij dat de methodologische aspecten van het 
onderzoek op zodanige wijze expliciet zijn gemaakt dat de lezer van het onderzoeksrapport kan volgen hoe het onderzoek is uitgevoerd, en het onderzoek ook kan beoordelen en het zou kunnen beoordelen zonder tot andere resultaten te komen (Van IJzendoorn \& Miedema, 1986; Smaling, 1987; Wester, 1995). De onderzoeksresultaten dienen daarvoor zo min mogelijk van toevalligheden afhankelijk te zijn. De toevalligheidselementen kunnen zijn veroorzaakt door de situatie en de omgeving waarin het interview plaatsvindt, de interviewer, de geïnterviewde en de vragen ('t Hart et al., 1996).

Belangrijk voor betrouwbaarheid zijn de homogeniteit en de gebruikte begrippen. Respondenten dienen onder de gebruikte begrippen hetzelfde te verstaan en zich vrij te voelen om alles te vertellen wat ze kwijt willen. Wanneer een onderzoek niet betrouwbaar is, is het in geen geval valide (Baarda et al., 2001).

\section{Interne betrouwbaarheid}

De interne betrouwbaarheid wordt beschreven als de mate waarin verschillende onderzoekers binnen hetzelfde onderzoeksgebied tot dezelfde resultaten zouden komen of de mate van overeenstemming tussen onderzoekers binnen hetzelfde onderzoek. Er worden een paar strategieën gehanteerd om de interne betrouwbaarheid van kwalitatief onderzoek te verhogen (Baarda et al., 2001; Meijer, 1999; Merriam, 1988; Janssens, 1985):

- Het gebruikmaken van dataregistratie (audio-opname en aantekeningen) en data-analyse-instrumenten.

- Zorgvuldige en nauwkeurige observatie en het maken van aantekeningen verhogen de validiteit van het onderzoek.

- Het toepassen van het triangulatieprincipe: diverse bronnen gebruiken om zo veel mogelijk informatie te verkrijgen.

In dit onderzoek is controle op interne betrouwbaarheid van de gebruikte onderzoeksprocedure gewaarborgd door aandacht te besteden aan de volgende aspecten:

De interviews zijn met behulp van een cassetterecorder opgenomen om zo min mogelijk informatie verloren te laten gaan. Daarnaast zijn tijdens de interviews regelmatig aantekeningen gemaakt en deze werden na ieder interview uitgewerkt.

Het triangulatieprincipe is toegepast. Er is getracht dit aspect te verhogen door een nauwkeurige observatie en het toepassen van de interpersoonlijke gespreksmethode van Leary.

Verder is gebruikgemaakt van een uitgewerkte topiclijst. De topiclijst bevatte voor alle respondenten dezelfde vraagstelling. Er is verder geen aparte lijst gebruikt voor de twee groepen. Er is wel bij het stellen van vragen rekening gehouden met de specifieke situatie van asielzoekers. Het concept van de topiclijst is uitgetest op vijf respondenten die eerder de vragenlijst van het kwantitatieve onderzoek hebben ingevuld. Deze behoorden niet tot de casestudie. Uit deze test is de definitieve versie van de topiclijst ontstaan. De voornaamste conclusie was dat een aantal vragen niet goed beantwoord kon worden omdat een aantal begrippen niet duidelijk gedefinieerd was. Deze begrippen zijn verbeterd in de definitieve versie. Sommige respondenten gebruikten hun dagboeken en/of andere 
documenten tijdens het interview. De interviews zijn op verschillende dagen en op verschillende tijdstippen gehouden.

\section{Externe betrouwbaarheid}

De herhaalbaarheid van het onderzoek door andere, onafhankelijke onderzoekers wordt externe betrouwbaarheid genoemd (Smaling, 1987; Janssens, 1985). Door het hanteren van een paar strategieën is het mogelijk om de externe betrouwbaarheid te verhogen (Kirk \& Miller, 1986; Smaling, 1987; Goetz \& LeCompte,1984). De volgende strategieën zijn toegepast:

- Het expliciteren van de theoretische inzichten van de onderzoeker.

- De nauwkeurige beschrijving van de situatie en de conditie van het onderzoek.

- De nauwkeurige beschrijving van de methodiek en technische informatie.

- De nauwkeurige beschrijving van de rol en de positie van de onderzoeker.

Verder is in onderzoek 2 getracht het theoretische aspect expliciet te maken door het samenstellen van een topiclijst.

De positie van de onderzoekster binnen de context van het onderzoek met betrekking tot de mate van objectiviteit is eerder in paragraaf 9.2.4.1 aan de orde geweest.

\subsubsection{Validiteit}

Bij validiteit gaat het om de vraag of het onderzoek datgene meet wat het moet meten. De vraag die hierbij gesteld moet worden, is of de interpretatie van de onderzoeker overeenkomt met de werkelijkheid.

Over het algemeen worden drie soorten validiteit onderscheiden:

\section{Constructvaliditeit}

Constructvaliditeit, ook wel begripsvaliditeit of inhoudsvaliditeit genoemd, is de enige validiteit die voorafgaande aan de verzameling van data wordt vastgesteld. Het gaat in principe om te bepalen of de theoretische begrippen terugkomen in de in de operationele voorstellingen gebruikte begrippen. Men wil weten of het meetinstrument het bedoelde begrip in zijn verschillende aspecten goed weerspiegelt (Swanborn, 1987). Constructvaliditeit is vooral belangrijk indien 'niet observeerbare constructen' gemeten worden, bijvoorbeeld intelligentie, angst, attitude, creativiteit.

Yin (1989) beschrijft drie soorten strategieën waardoor de constructvaliditeit kan worden verhoogd, te weten:

- Triangulatie: het hanteren van diverse bronnen om zo veel mogelijk informatie over de concepten ter beschikking te krijgen (Swanborn, 1987, 1996; Baarda et al., 2001; Van Buuren et al., 1990; Van Dijk et al., 1991; Miles \& Huberman, 1994; Teunissen, 1985).

- Consistentie in de bewijsvoering: men tracht deze zogenaamde 'chain of evidence' zo helder mogelijk te houden.

- Het voorleggen van gespreksverslagen aan de informanten ter correctie. 
Om een beter beeld te krijgen van de persoonlijke beleving van respondenten is in dit onderzoek gekozen voor triangulatieaanpak. Door nauwkeurige observatie door de onderzoekster en zelfrapportage van respondenten is een beeld gevormd van de subjectieve beleving van respondenten.

De uitwerking van de interviews is aan de respondenten voorgelegd en hun reacties op de schriftelijke rapporten is gevraagd. Dit heeft tot aanvulling en correcties geleid.

\section{Interne validiteit}

Een onderzoek heeft een hoge interne validiteit wanneer een terecht verband bestaat tussen de resultaten en de conclusies in de verschillende fasen van het onderzoek met de werkelijkheid waaraan ze ontleend zijn. In dit geval zijn de gevonden samenhangen aan de veronderstelde oorzaken toe te schrijven.

Er worden verschillende strategieën genoemd waardoor de interne validiteit kan worden verhoogd (Smaling, 1987; Merriam, 1988; Meijer, 1999; Beijaard \& Verloop, 1996):

\section{Triangulatie}

- Communicatieve validering: de respondenten de vraag voorleggen of de onderzoeker hun opvattingen juist heeft geïnterpreteerd.

- Lange onderzoeksperiode om onderzoekers aan het onderzoek te laten wennen.

- De onderzoeker moet proberen eigen vooroordelen bij het onderzoeksproces te achterhalen.

In deze studie is er sprake van een intensieve en langdurige periode van contact met de respondenten, waarmee hopelijk een goede 'fit' is ontstaan tussen theorie en praktijk. De interviews en rapportages sluiten aan op 'het verhaal' van de respondenten.

Interne validiteit is in dit onderzoek gewaarborgd door controle te houden op aspecten als subjectiviteit, niet direct vastleggen van observaties en controle van interpretaties bij respondenten. Er is naar gestreefd om zo veel mogelijk waardevolle informatie te verzamelen met als doel de vraagstelling te beantwoorden. Het principe van contextualiteit (zowel algemeen door alle geïnterviewden als specifiek per respondent) is in acht genomen om een goede beschrijving te kunnen geven over de beleving en de interpretatie van de gezichtspunten van de respondenten. Daarmee hoop ik de basis te hebben gelegd voor een voldoende interne validiteit, waardoor het mogelijk is om causale verbanden te leggen tussen de variabelen. Dit heb ik gedaan door gebruik te maken van wat Yin (1989) 'pattern matching' noemt, het vergelijken van de verwachte theoretische patronen met de patronen die we in de empirie, dus in de cases, aantroffen.

\section{Externe validiteit}

Er is sprake van externe validiteit als de gevonden samenhang is te generaliseren naar de relevante populatie. Betrouwbaarheid en interne validiteit zijn de voorwaarden voor generaliseerbaarheid (Baarda et al., 2001; Wallen \& Frankel, 2001). 
In het kwalitatief onderzoek gaat het meer om de inhoudelijke en analytische generalisatie dan om statistische generalisatie. Daarom is het aspect representativiteit van de respondenten hier minder relevant.

Van een hoge externe validiteit is sprake wanneer de onderzoeksresultaten goed generaliseerbaar zijn. In de praktijk kan men nooit met zekerheid beweren dat de onderzoeksresultaten uit de ene situatie in het geheel van toepassing zijn op een andere situatie. $\mathrm{Er}$ is geprobeerd de onderzoekssituatie op belangrijke punten te laten samenvallen met de situatie waarin men thans leeft. De mate van overdraagbaarheid van de onderzoekssituatie naar de beoogde alledaagse situatie heb ik in dit onderzoek zo veel mogelijk tot haar recht laten komen. Dit heb ik gewaarborgd door de respondenten in hun eigen omgeving en in een reële situatie te interviewen. Op andere punten van de externe validiteit heb ik eerder in dit hoofdstuk gewezen.

\subsubsection{Operationalisering topiclijst}

Voor dit onderzoek is een topiclijst samengesteld. De topiclijst is voor een groot deel gebaseerd op de vragenlijsten die al bij onderzoek 1 gebruikt zijn. Er is gekozen voor de meest essentiële vragen met betrekking tot zowel individuele/psychologische factoren als de begeleidingsfactoren.

De vragen zijn explorerend van aard. Om een goed beeld te geven van de interviews en de interne validiteit van het onderzoek te verhogen, is gebruikgemaakt van de triangulatiemethode. Deze methode wordt vooral bij casestudies aanbevolen ter verhoging van de interne validiteit (Yin \& Heald, 1975; Swanborn, 1987, 1996; Murray, 2002).

Tevens werd hierbij een aantal vragen gebruikt die in onderzoek 1 tot schalen zijn verwerkt.

\section{Topiclijst}

De topiclijst is mede bedoeld om door middel van open vragen illustraties en verdieping te geven van de resultaten van onderzoek 1. Daarnaast is geprobeerd om een beschrijving te verkrijgen van de huidige situatie en positie van de respondenten.

Tevens is met behulp van de topiclijst geprobeerd zo veel mogelijk informatie te verzamelen over de persoonlijke beleving van de respondenten met de begeleiding in Nederland. Mijn persoonlijke kennis en ervaring met begeleiding is ook gebruikt bij het samenstellen en het opzetten van de topiclijst.

De vragen van de topiclijst zijn samengebracht in vijf clusters, te weten:

\section{Cluster 1: Definitie en de betekenis van integratie}

- Welke betekenis geven de respondenten aan het woord integratie?

- Wat beweegt de respondenten om te gaan/willen integreren?

- Welke factoren hebben in zowel positieve als negatieve zin effect op hun integratie?

- Denkt respondent dat hij/zij geïntegreerd is, en zo ja, waarom? 
Cluster 2: De rol van begeleiding bij de integratie

- Welke rol speelt de begeleiding bij een succesvolle integratie?

- Welke specifieke aspecten van de begeleiding vinden de respondenten van belang voor een geslaagde integratie?

- Hoe beleven de respondenten de begeleiding?

- Hebben de respondenten het gevoel dat ze door de formele begeleiding meer kansen maken in Nederland?

Cluster 3: De rol van de begeleidingsfactoren (vertrouwen, eerlijke procedure, inspraak) bij het integratieproces

- Welke rol spelen volgens respondenten de systeemfactoren bij het waarnemen van de kansen?

- Welke kenmerken van het systeem van begeleiding en/of begeleider leiden tot meer vertrouwen bij de respondent?

- Heeft de respondent enige invloed (inspraak) kunnen uitoefenen op zijn/haar begeleiding en zo ja, hoe?

- Vindt de respondent het systeem van begeleiding op basis van zijn/haar persoonlijke ervaring rechtvaardig en eerlijk?

Cluster 4: De rol van individuele/psychologische factoren bij het integratieproces

- Welke effecten hebben individuele/psychologische factoren gehad op de perceptie van kansen in Nederland?

- Hoe is de persoonlijke beleving van de respondenten ten opzichte van depressie, trauma's en hun copingstijl?

- Welke effecten hebben/hadden deze factoren op het waarnemen van kansen in Nederland?

Cluster 5: De rol van discriminatie en cultuurverschil bij het waarnemen van kansen De volgende vragen maken deel uit deze cluster:

- Wat is uw ervaring met discriminatie?

- Hebt u tijdens uw begeleiding te maken gehad met discriminatie?

- Heeft volgens u discriminatie enig effect op het waarnemen van uw kansen in Nederland?

- Ziet u verschillen tussen Iran en Nederland met betrekking tot de begeleiding, en zo ja, welke?

De topiclijst heeft zowel een open als een gesloten karakter. Daarmee is deze lijst een combinatie van aanbevelingen van enerzijds Miles \& Huberman (1994) en anderzijds Dyer \& Wilkins (1991). Miles \& Huberman pleiten er op basis van Yins aanbevelingen (Yin, 1989) voor om gestandaardiseerd te werk te gaan en wel met gecodeerde onderzoeksvragen. Dyer \& Wilkins zoeken naar een meer open onderzoeksopzet. 


\subsubsection{Analysemethode: Uitgangspunten. Presentatie van de gegevens}

Bij de analyse van de interviews is de methode van Baarda (2001: 168-196) gehanteerd. Bij de analyse van gegevens vormt de probleemstelling het centrale uitgangspunt voor de analyse. De probleemstelling is de focus van waaruit de interviews bekeken worden. Het onderzoek leverde een grote hoeveelheid onderzoeksgegevens op die moesten worden gereduceerd en gestructureerd om relevante informatie over te houden voor beantwoording van de probleemstelling en onderzoeksvragen. Hieronder wordt een beschrijving gegeven van de stappen en de wijze waarop de gegevens van het onderzoek zijn verwerkt.

\section{Stap 1. Registratie en het selecteren van informatie}

De eerste stap was het registreren en opslaan van de verzamelde gegevens. Daarna zijn alle niet-relevante gegevens geschrapt. Tijdens het uitschrijven van de interviews werd een globaal beeld gevormd ten aanzien van de respondenten.

\section{Stap 2. Splitsing in fragmenten}

$\mathrm{Na}$ de selectie van de relevante tekst is deze opgesplitst in fragmenten. leder fragment bevatte één onderwerp.

\section{Stap 3. Het labelen}

Het materiaal werd nog een keer gelezen en er werden labels toegekend aan stukjes tekst. De labels waren zowel afkomstig vanuit het theoretische kader van het onderzoek als van de inhoud van het materiaal. Tijdens dit proces werden ideeën en vragen gevormd over de relaties tussen de stukken tekst.

\section{Stap 4. Ordening, reduceren en beschrijving}

In deze fase werden de tekstonderdelen met dezelfde labels bij elkaar gezet, waardoor ordenen van het materiaal plaatsvond. Daarna werd nagegaan of alle tekst die bij een bepaald trefwoord was ondergebracht, daadwerkelijk daar ook thuishoorde.

\section{Stap 5. Het definiëren van de kernlabels}

Alle kernlabels zijn in deze fase gedefinieerd en er is nog een keer nagegaan of de vastgestelde labels dekkend zijn.

\section{Stap 6. De intersubjectiviteit}

Om de intersubjectiviteit te controleren is aan collega-onderzoekers gevraagd om een aantal gelabelde interviews onafhankelijk van de onderzoekster te labelen.

\section{Stap 7. Interpretatie}

Het uitgangspunt voor deze fase in de verwerking van de gegevens was de beschrijvende samenvatting van de opvattingen van de respondenten. Deze beschrijvende samenvatting vond plaats met behulp van de theorie die in het theoretische kader van het 
onderzoek al eerder in hoofdstuk 1 aan de orde is geweest. Uitgangspunt bij dit proces was zowel de theoretische als de natuurlijke context van waaruit de opvattingen van de respondenten afkomstig zijn. Voor deze studie betekende dit dat de gegevens moesten worden geïnterpreteerd met behulp van de theorie over begeleidingsconcepten, en dat tegelijkertijd recht moest worden gedaan aan de complexiteit van de fase van integratie, waarin respondenten zich bevinden.

Bij de analyse van de gegevens en categorie-indeling heb ik me niet beperkt tot het eruit halen van strakke lijnen in interviewfragmenten. Eigen kennis en eigen inzichten zijn uiteraard ook leidend geweest. Het aspect van wisselwerking tussen heden en verleden is ook een belangrijk uitgangspunt van dit onderzoek. De wisselwerking tussen de historische context (het verleden en de achtergrondfactoren) en de huidige context (het heden) is in ogenschouw genomen. De subjectieve beleving, verwachtingen, betekenisgeving, motivatie en intentie van de respondenten zijn andere belangrijke uitgangspunten voor dit onderzoek. Behalve gezamenlijke elementen in de verhalen van respondenten, is diversiteit een opvallend punt, vooral als het over de belevingen van de respondenten gaat.

In de beschrijving van de resultaten zijn de individuele verhalen over verschillende thema's verspreid, zodat ze voor de respondenten zelf niet herkenbaar worden. Dit komt de privacy van de respondenten ten goede.

\section{Stap 8. Analyse over alle respondenten}

Er zijn diverse bewerkingen uitgevoerd bij iedere afzonderlijke respondent. De bewerkingen hebben geleid tot het verkrijgen van portretten van de respondenten. Op basis van deze portretten is een analyse over alle respondenten uitgevoerd. Er werd gezocht naar overeenkomsten en verschillen tussen de twee onderzoeksgroepen en ook binnen de groepen respondenten. Het totale proces van gegevensverwerking heeft stap voor stap op een steeds abstracter niveau plaatsgevonden. Het materiaal werd steeds verder gereduceerd waardoor er ook een steeds compacter en beter begrip over ontstond.

In tabel 9.4 wordt een overzicht gegeven van de stappen die ik heb gezet om de gegevens te verwerken. 
Tabel 9.4 Overzicht van de stappen van de gegevensverwerking

\begin{tabular}{|c|c|c|c|}
\hline \multicolumn{2}{|c|}{ Stap } & \multirow{2}{*}{$\begin{array}{l}\text { Proces } \\
\text { Opslaan van gegevens } \\
\text { Materiaal opslaan } \\
\text { Niet-relevante informatie } \\
\text { verwijderen }\end{array}$} & \multirow{2}{*}{$\begin{array}{l}\text { Product } \\
\text { Logboekteksten } \\
\text { Uitgetypte interviews } \\
\text { Observatieverslagen }\end{array}$} \\
\hline 1. & Registratie/selecteren & & \\
\hline 2. & $\begin{array}{l}\text { Splitsen in } \\
\text { fragmenten }\end{array}$ & Globaal beeld vormen & Gefragmenteerde teksten \\
\hline 3. & Het labelen & $\begin{array}{l}\text { Het lezen van materiaal } \\
\text { Trefwoorden toekennen } \\
\text { Het vormen van ideeën en } \\
\text { vragen }\end{array}$ & $\begin{array}{l}\text { Geordende teksten uit- } \\
\text { mondend in een beschrij- } \\
\text { ving van de opvattingen }\end{array}$ \\
\hline 4. & Ordenen/reduceren & $\begin{array}{l}\text { Samenvoegen van labels } \\
\text { Controle van trefwoorden }\end{array}$ & $\begin{array}{l}\text { Geordende en compacte } \\
\text { tekst }\end{array}$ \\
\hline 5. & $\begin{array}{l}\text { Definiëren van de } \\
\text { kernlabels }\end{array}$ & $\begin{array}{l}\text { Controle uitvoeren door een } \\
\text { onafhankelijke persoon }\end{array}$ & Definitieve labels \\
\hline 6. & Intersubjectiviteit & $\begin{array}{l}\text { Geordende gegevens met } \\
\text { behulp van theorie interprete- } \\
\text { ren, rekening houdend met de } \\
\text { complexiteit van de bestaande } \\
\text { werkelijkheid }\end{array}$ & - \\
\hline 7. & Interpreteren & $\begin{array}{l}\text { Het weergeven van de inhoud } \\
\text { van de opvattingen }\end{array}$ & Respondentportretten \\
\hline 8. & $\begin{array}{l}\text { Analyse over alle } \\
\text { respondenten }\end{array}$ & $\begin{array}{l}\text { Portretten vergelijken m.b.t. } \\
\text { verschillen en overeenkomsten; } \\
\text { vraagstelling beantwoorden }\end{array}$ & $\begin{array}{l}\text { Definitieve analyse en } \\
\text { conclusie }\end{array}$ \\
\hline
\end{tabular}




\subsection{Onderzoek 3: correlationeel onderzoek naar psychisch (on)welbevinden}

Het derde onderzoek is een vervolgonderzoek op het eerste vergelijkende onderzoek 1. Met dit onderzoek wordt getracht een beeld te geven van het ervaren (on)welbevinden en de psychische gezondheid van de respondenten. Dit onderzoek is verricht tussen 20082010. Onderzoek 3 werd uitgevoerd met behulp van vier vragenlijsten.

\subsubsection{Kenmerken van de onderzoeksgroep}

De steekproef bestond uit 119 Iraanse vluchtelingen. Alle respondenten waren in het bezit van een verblijfsvergunning en ze woonden langer dan 5 jaar in Nederland. De verblijfsduur verschilde van 6 tot 25 jaar. De deelnemers waren ouder dan 18 jaar. Zowel bij het eerste als bij het tweede vergelijkende onderzoek mochten de kinderen van vluchtelingen die ouder waren dan 18 jaar deelnemen aan het onderzoek. Alle respondenten waren bekend met het invullen van de vragen met meerkeuzemogelijkheden. Zoals bij het eerste onderzoek, is bij dit onderzoek ook gekozen voor een heterogene samenstelling van de steekproef wat leeftijd, opleidingsniveau en woonplaats betreft. De bedoeling was om de groep zo gevarieerd mogelijk samen te stellen.

\subsubsection{Procedure}

Tussen 2008 en 2010 is een studie verricht onder 119 Iraanse vluchtelingen. De bedoeling was om een zo goed mogelijk beeld te krijgen van de psychische gezondheid van de respondenten die al deel hadden genomen aan het eerste correlationeel onderzoek in de jaren 2004-2007. Asielzoekers die mee hebben gedaan aan het eerste onderzoek, beschikken momenteel over een verblijfsvergunning voor een bepaalde tijd. Dit is voor een groot deel tot stand gekomen mede dankzij de pardonregeling in 2008. Alle respondenten van dit onderzoek die onder de pardonregeling vallen, beschikken over een verblijfsvergunning voor bepaalde tijd. Het betreft 55 respondenten.

Mijn intentie om bij dit onderzoek vooral de psychische gezondheid van de respondenten te onderzoeken, heeft vooral te maken met de hoge mate van psychische klachten van de respondenten bij het eerste onderzoek (onderzoek 1). Uit de analyses van de gegevens van het eerste kwantitatieve onderzoek 1 bleek dat er sprake is van een hoge mate van depressieve en angstklachten, en een hoge mate van algemene psychopathologie bij de meerderheid van de respondenten. Dit geldt dus voor zowel asielzoekers als vluchtelingen van het eerste onderzoek.

Naar aanleiding van de bevindingen van het eerste onderzoek en steunend op de literatuurstudie is besloten om een duidelijker beeld te krijgen van de mate van psychopathologieklachten en daarnaast ook van de ervaren trauma's door de respondenten.

Het was een moeilijke opgave omdat het bereiken van respondenten van onderzoek 1 veel moeilijker lag dan we in eerste instantie dachten. Dit had te maken met diverse oorzaken, onder andere de anonimiteit van de respondenten, het veranderen van hun verblijfplaats, het verdwijnen in de illegaliteit, het immigreren naar andere landen en de terugkeer naar Iran. 
Mijn uitgangspunt was om voldoende vragenlijsten ingevuld te krijgen, rekening houdend met verandering van de woonplaatsen van de respondenten. Om de respondenten van onderzoek 1 te kunnen achterhalen, heb ik in eerste instantie contact opgenomen met sommige deelnemers en netwerken die voor mij beschikbaar waren. Het bereiken van de oude statushouders was in de praktijk gemakkelijker dan het bereiken van de nieuwe statushouders. Omdat ik niet onvoldoende 'oude respondenten' kon bereiken, is besloten om de steekproef samen te stellen van de beschikbare oude respondenten en de nieuwe deelnemers.

Uiteindelijk moest ik me beperken tot een groep van 119 respondenten waarvan bijna $20 \%$ uit de oude respondenten bestond.

Het benaderen van de respondenten kwam tot stand op diverse manieren, onder andere persoonlijke contacten, telefonische contacten, via via, per mail en schriftelijk. Meer dan 300 mensen zijn benaderd en uiteindelijk zijn 129 vragenlijsten geretourneerd waarvan 119 zijn gebruikt in het onderzoek.

De rest heeft de vragenlijsten niet teruggestuurd en/of niet compleet ingevuld.

De onderzoeksgroep bestaat uit 64 oude statushouders en 55 nieuwe statushouders die voor een groot deel door de pardonregeling in aanmerking kwamen voor een verblijfsvergunning. Als dank voor hun deelname kreeg iedere respondent 20 euro voor de afgestane tijd en inzet. Niet alle respondenten hebben hier positief op gereageerd. Meer dan de helft van de (ex-)vluchtelingen heeft het geld geweigerd en heeft vrijwillig meegedaan aan het onderzoek.

Instructie van de vragenlijsten werd zowel schriftelijk als mondeling gegeven. Respondenten mochten mij bellen in geval van onduidelijkheid over de instructie.

Alle respondenten kregen schriftelijk de uitslagen van hun onderzoek. Naast hun individuele vragenlijstprofiel kreeg iedereen inhoudelijke informatie over de vier vragenlijsten: de UCL, de SCL-90, de HTQ en de PSS. Daarnaast heeft iedereen een demografische vragenlijst ingevuld.

\subsubsection{Meetinstrumenten}

De vier meetinstrumenten worden zowel toegepast in het onderzoek als ten behoeve van de diagnostiek.

Hieronder zijn de gebruikte meetinstrumenten kort beschreven. Alle vragenlijsten zijn vertaald in het Farsi. De SCL-90 en de UCL zijn bij de eerste fase van deze studie ook afgenomen. Dezelfde versies zijn gebruikt voor onderzoek 3. Het vertalingsprotocol is eerder uitgelegd. Voor HTQ en PSS bestaan er standaardversies in het Farsi.

\section{De SCL-90}

De vragenlijst is een multidimensionele klachtenlijst, gebaseerd op zelfbeoordeling door de onderzochte. De vragenlijst vraagt naar recent ervaren klachten, zowel lichamelijk als psychisch. De SCL-90 bestaat uit 90 items. De items omschrijven klachten in 8 dimensies: agorafobia (7 items), angst (10 items), depressie (16 items), somatische klachten (12 items), insufficiëntie van denken en handelen (9 items), wantrouwen en interpersoonlijke sensitiviteit (18 items), hostiliteit (6 items), slaapproblemen (3 items). De SCL-90 kent ook een 
totaalscore, psychoneuroticisme (PSNEU), deze drukt het psychoneurotisch-somatisch onwelbevinden uit (Arrindell \& Ettema,1986). De betrouwbaarheid van de subschalen van de gebruikte SCL-90-versie bij onderzoek 3 varieert van 0.73 tot 0.90 .

Voor analyses van de gegevens van de UCL zijn genormeerde scores gebruikt.

$1=$ zeer laag

2 = laag

$3=$ benedengemiddeld

$4=$ gemiddeld

$5=$ bovengemiddelde

$6=$ hoog

$7=$ zeer hoog

De UCL

De vragenlijst wordt toegepast ten behoeve van het vaststellen van het karakteristieke copinggedrag bij confrontatie met problemen. Het gaat niet over de onveranderlijke eigenschappen, maar over de voorkeuren voor copingsvormen in diverse situaties. De reactiewijzen zijn mede tot stand gekomen door vroegere leerervaringen, opvoedingspatronen en persoonlijkheidskenmerken. De UCL bevat 47 items en 7 schalen: actief aanpakken (7 items), palliatieve reactie ( 8 items), vermijden (8 items), sociale steun zoeken (6 items), passief reactiepatroon (7 items), expressie van emoties ( 3 items) en geruststellende gedachten (5 items).

De betrouwbaarheid van de subschalen van de gebruikte versie bij onderzoek 3 is redelijk tot goed en deze varieert van 0.71 tot 0.75 .

Voor analyses van de gegevens van de SCL-90 zijn genormeerde scores gebruikt. Dit is gedaan om een beter overzicht te krijgen van het niveau van de klachten. De volgende categorieën zijn gebruikt:

$$
\begin{aligned}
& 1=\text { zeer laag } \\
& 2=\text { laag } \\
& 3=\text { gemiddeld } \\
& 4=\text { hoog } \\
& 5=\text { zeer hoog }
\end{aligned}
$$

\section{De HTQ}

De HTQ is een zelfbeoordelingsvragenlijst en bestaat uit vier gedeelten. Deel 1 bestaat uit 17 traumatische gebeurtenissen, zoals gebrek aan water en voedsel, marteling, verkrachting, de moord op familie of vrienden. In deel 2 wordt cliënten gevraagd de meest traumatische gebeurtenis te beschrijven die ze hebben meegemaakt. Deze vraag is weggelaten bij dit onderzoek. In deel 3 van de HTQ staan 4 items over traumatische gebeurtenissen waarbij hoofdverwondingen optraden. Deel 4 bestaat uit 30 vragen over posttraumatische stresssymptomen. De eerste 16 zijn gebaseerd op DSM-IV-criteria voor PTSS. De overige 14 items gaan over de symptomen die te maken hebben met de doorgemaakte traumatische ervaringen. 
De totale score voor het aantal PTSS-symptomen is berekend door het totaal van de scores op de items te delen door het nummer van beantwoorde items. Bij een score hoger dan 2.5 krijgt een persoon de diagnose PTSS.

De PSS

De PSS is een zelfrapportage-trauma- en angstvragenlijst die ontwikkeld is door FOA et al. (1993). Deze vragenlijst kan worden afgenomen zowel in de klinische sessies als bij het onderzoeken van PTSS- en angstklachten. PSS kan worden gebruikt als differentiële diagnose tussen PTSS en de overige angstklachten. Voor analyses van de gegevens van de PSS zijn originele scores gebruikt.

Tabel 9.5 Vergelijking van enkele kenmerken van de onderzoeksgroep met het landelijke onderzoek in percentage (CBS, 2007-2008)

\begin{tabular}{|c|c|c|}
\hline Kenmerk & Landelijke percentages & $\begin{array}{l}\text { Onderzoeksgroep } \\
\text { percentages }\end{array}$ \\
\hline \multicolumn{3}{|l|}{ Aantal } \\
\hline Mannen & $56 \%$ & $58 \%$ \\
\hline Vrouwen & $44 \%$ & $42 \%$ \\
\hline \multicolumn{3}{|l|}{ Opleidingsniveau } \\
\hline Lagere school & $10 \%$ & $7.0 \%$ \\
\hline Middelbare school & $57 \%$ & $48 \%$ \\
\hline HBO/WO & $31 \%$ & $27 \%$ \\
\hline Geen diploma & $2.0 \%$ & $0.0 \%$ \\
\hline \multicolumn{3}{|l|}{ Leeftijd } \\
\hline $0-9$ & $13 \%$ & $0.0 \%$ \\
\hline $10-19$ & $15 \%$ & $0.80 \%$ \\
\hline $20-29$ & $26 \%$ & $12 \%$ \\
\hline $30-39$ & $19 \%$ & $28 \%$ \\
\hline $40-49$ & $10 \%$ & $37 \%$ \\
\hline 50-plus & $28 \%$ & $21 \%$ \\
\hline \multicolumn{3}{|l|}{ Burgerlijke staat } \\
\hline Alleenstaand & $30 \%$ & $25 \%$ \\
\hline $\begin{array}{l}\text { Getrouwd/Samenwonend met } \\
\text { kinderen }\end{array}$ & $57 \%$ & $51 \%$ \\
\hline Eenouderhuishouden & $23 \%$ & $19 \%$ \\
\hline
\end{tabular}

Uit de bovenstaande tabel 9.5 blijkt dat de onderzoeksgroep redelijk vergelijkbaar is met de landelijke onderzoeksgegevens van het CBS. 


\subsubsection{Validiteit en betrouwbaarheid}

Zowel bij onderzoek 1 als bij onderzoek 3 is getracht om de interne en inhoudsvaliditeit van de vier vragenlijsten te verhogen. $\mathrm{Er}$ is vooral aandacht besteed aan de begrijpelijkheid voor de respondenten. De vragenlijsten zijn vooraf door enkele vertegenwoordigers van beide doelgroepen ingevuld waarbij is gevraagd onduidelijkheden over de vragen te rapporteren. De lijsten zijn ook mondeling met hen besproken. Over het algemeen waren er geen bijzondere veranderingen nodig. Er waren wel opmerkingen met betrekking tot de vertaling van de HTQ-vragenlijst.

Bij het bestuderen van de correlaties (zie hoofdstuk 10) blijkt dat de traumavragenlijsten op een logische wijze (zie bijlage 4, tabel 2) met elkaar samenhangen. Dit is een aanwijzing voor de begripsvaliditeit.

Voor de betrouwbaarheid van het vragenlijstonderzoek wordt verwezen naar de Cronbach's alfa's van de meetinstrumenten.

\subsubsection{Data-analyse}

Voor de data analyses zijn de ruwe scores gebruikt. Het meetniveau van de vier vragenlijsten (SCL-90, UCL, HTQ, PSS) is interval. Het variabele geslacht kent een nominaal meetniveau. Meetniveau, gemiddelde en spreiding van alle respondenten treft $u$ aan in bijlage 2 .

Om een beter overzicht te geven van de spreiding van de leeftijd van respondenten is de variabele leeftijd in vijf klassen van negen jaar verdeeld. 
Deel IV

Resultaten 


\section{Hoofdstuk10}

\section{Resultaten}

De resultaten worden per onderzoek beschreven. Voor onderzoek 1 worden de resultaten vermeld van de toetsing van de hypothesen. Voor onderzoek 2 worden de resultaten op de explorerende vragen weergegeven. Daarna volgt een samenvattend overzicht van de antwoorden op deze vragen. De beschrijving van de resultaten van onderzoek 3 heeft dezelfde structuur als de beschrijving van de resultaten van onderzoek 1. Ik sluit ieder onderzoek af met een korte thematische samenvatting.

\subsection{Onderzoek 1: data-analyse}

Het meetniveau van de vier vragenlijsten (SCL-90, UCL, BDI, begeleidingsvragenlijst) is interval. De variabele geslacht kent een nominaal meetniveau. Meetniveau, gemiddelde en spreiding van alle respondenten treft $u$ aan in bijlage 2 .

Om een beter overzicht te geven van de spreiding van de leeftijd van respondenten is de variabele leeftijd in vijf klassen van negen jaar verdeeld.

\subsubsection{Toetsing hypothesen}

De vraagstelling en de hypothesen van onderzoek 1 zijn eerder vermeld in hoofdstuk 1. De beschrijving van de toetsing is gebeurd in dezelfde volgorde als waarmee ze in hoofdstuk 1 is weergegeven. De paragrafen zijn ook thematisch ingedeeld. De hypothesen bij het betreffende thema worden aan het begin van de paragraaf vermeld.

Hieronder volgen de hypothesen van onderzoek 1:

- Respondenten schatten hun kansen op positieverbetering met begeleiding hoger in dan zonder begeleiding.

- Respondenten die hun begeleiding als rechtvaardig en betrouwbaar ervaren en het gevoel hebben dat ze meer inspraak hebben in hun begeleiding, schatten hun kansen op positieverbetering hoger in.

- Het beschikken over een verblijfsvergunning heeft een positief effect op de kansperceptie en op de ervaren begeleidingsfactoren (rechtvaardigheid, vertrouwen, inspraak).

- De mate van depressie en psychopathologieklachten is over het algemeen hoog en asielzoekers ervaren meer last van depressie en diverse psychopathologieklachten dan (ex-)vluchtelingen. 
- Er bestaat verschil tussen de twee groepen met betrekking tot de gehanteerde copingstijlen. Asielzoekers passen meer passieve en vermijdende copingstijlen toe dan ex-vluchtelingen.

- Individuele en psychologische factoren hebben een modererend effect op de relatie tussen de ervaren kans op positieverbetering en de begeleidingsfactoren.

\subsubsection{Hypothese 1}

Hypothese 1: respondenten schatten hun kansen op positieverbetering met begeleiding hoger in dan zonder begeleiding.

De eerste hypothese gaat ervan uit dat wanneer de begeleiding opgevat wordt als een vorm van sociale beïnvloeding, het succes van de begeleiding mede afhankelijk is van de wijze waarop deze beïnvloeding in psychologische zin vorm krijgt. Met andere woorden: als de begeleiding succes heeft, dan zouden respondenten (die alleen begeleiding kregen) de effecten van deze begeleiding op hun kansen op positieverbetering positief moeten inschatten.

Om hypothese 1 te onderzoeken, ga ik allereerst na of de respondenten de waargenomen kansen op de positieverbetering door de begeleiding positief inschatten. We hebben dan meteen een antwoord op onze hoofdhypothese. In de onderstaande tabel zijn de resultaten van de toetsing van hypothese 1 weergegeven.

Tabel 10.1 Inschatting van de respondenten (148) van hun kansen op positieverbetering door begeleiding

\begin{tabular}{|l|l|l|l|l|l|}
\hline $\begin{array}{l}\text { Vergroting van de kans } \\
\text { op }\end{array}$ & $\begin{array}{l}\text { Geheel } \\
\text { mee } \\
\text { eens }\end{array}$ & $\begin{array}{l}\text { Enigszins } \\
\text { mee eens }\end{array}$ & $\begin{array}{l}\text { Noch } \\
\text { eens, noch } \\
\text { oneens }\end{array}$ & $\begin{array}{l}\text { Enigs- } \\
\text { zins mee } \\
\text { oneens }\end{array}$ & $\begin{array}{l}\text { Geheel } \\
\text { mee } \\
\text { oneens }\end{array}$ \\
\hline Werk (baan vinden) & $53 \%$ & $32 \%$ & $11 \%$ & $4 \%$ & $0 \%$ \\
\hline Financiële situatie & $31 \%$ & $43 \%$ & $21 \%$ & $3 \%$ & $2 \%$ \\
\hline Algemene gezondheid & $33 \%$ & $46 \%$ & $14 \%$ & $4 \%$ & $3 \%$ \\
\hline Geestelijke gezondheid & $32 \%$ & $47 \%$ & $16 \%$ & $3 \%$ & $2 \%$ \\
\hline Beroepsvaardigheden & $30 \%$ & $50 \%$ & $15 \%$ & $4 \%$ & $1 \%$ \\
\hline Zelfvertrouwen & $23 \%$ & $43 \%$ & $19 \%$ & $8 \%$ & $7 \%$ \\
\hline Sociaal netwerk & $26 \%$ & $48 \%$ & $17 \%$ & $6 \%$ & $3 \%$ \\
\hline Vaste baan & $34 \%$ & $41 \%$ & $17 \%$ & $3 \%$ & $5 \%$ \\
\hline Cultuuroverbrugging & $40 \%$ & $28 \%$ & $24 \%$ & $6 \%$ & $2 \%$ \\
\hline
\end{tabular}


Uit tabel 10.1 blijkt dat de respondenten het over het algemeen eens zijn met de stelling dat de begeleiding de kansen op de positieverbetering vergroot.

Deze kansinschatting is het grootst bij het vinden van een baan (85\%) en het laagst bij het verhogen van het gevoel van zelfvertrouwen (66\%), waarbij de hoogste twee antwoordcategorieën samen zijn genomen. Een toetsing tegen de nulhypothese dat de respondenten geen positieverbetering inschatten door de begeleiding (middelste categorie) levert in alle gevallen een significant effect op, t(147)'s > 7.5; p's <.001. Ook een toets tegen de nulhypothese van een gelijke verdeling van de respondenten over de vijf categorieën levert een significant verschil op, X2(4, N = 148)'s > 64; p's <.001.

We kunnen concluderen dat de respondenten overwegend positieve waardering hebben voor hun begeleiding. Respondenten zien meer kansen door het verkrijgen van begeleiding dan zonder begeleiding. Hypothese 1 als de centrale hypothese van deze studie wordt bevestigd.

\subsubsection{Hypothese 2}

Hypothese 2: respondenten die hun begeleiding als rechtvaardig en betrouwbaar ervaren en het gevoel hebben dat ze inspraak hebben in hun begeleiding, schatten hun kansen op positieverbetering hoger in.

Om deze hypothese te toetsen zijn er correlaties berekend tussen de afhankelijke variabele kansperceptie en de drie onafhankelijke begeleidingsvariabelen (rechtvaardigheid, vertrouwen en inspraak).

Uit analyses blijkt het volgende:

- Er bestaat een significant verband tussen de onafhankelijke variabele rechtvaardigheid en de kansperceptie ( $r=0.46 ; \mathrm{N}=148 ; \mathrm{p}<0.01$ ). Respondenten die de begeleiding als rechtvaardig ervaren, hebben ook een hogere kansperceptie.

- Er bestaat een significant verband tussen de onafhankelijke variabele inspraak en de kansperceptie van de respondenten $(r=0.40 ; N=147 ; p<0.01)$. Respondenten die meer inspraak ervaren met betrekking tot hun begeleiding, ervaren ook een hogere kansperceptie.

- Er bestaat een significant verband tussen de onafhankelijke variabele vertrouwen en de kansperceptie van de respondenten $(r=0.46 ; N=147 ; p<0.01)$. Respondenten die meer vertrouwen hebben in hun begeleiding, hebben ook een hogere kansperceptie.

Hypothese 2 wordt bevestigd. De resultaten van de analyses staan vermeld in bijlage 2, tabel 1. 


\subsubsection{Hypothese 3}

Hypothese 3: het beschikken over een verblijfsvergunning heeft een positief effect op de kansperceptie en de ervaren drie begeleidingsfactoren (vertrouwen, rechtvaardigheid en inspraak). Deze hypothese is getoetst met een t-toets. Uit de analyses blijkt het volgende:

- Het effect van in het bezit zijn van een verblijfsvergunning op kansperceptie van de respondenten is over de hele linie significant: $t(146)=3.08 ; p=.002$. (Ex-)vluchtelingen zien meer kansen $(M=37.78 ; S D=7.10)$ dan asielzoekers $(M=33.54 ; S D=9.42)$.

- Het effect van het bezit van een verblijfsvergunning op vertrouwen in begeleiding is significant: $t(145)=3.89 ; p=.0001$. (Ex-)vluchtelingen hebben meer vertrouwen $(M=10.52 ; S D=3.05)$ in begeleiding dan asielzoekers $(M=8.68 ; S D=2.66)$.

- Het effect van het bezit van een verblijfsvergunning op inspraak is significant: $t(146)$ $=5.60 ; \mathrm{p}<.0001$. (Ex-)vluchtelingen ervaren meer inspraak met betrekking tot hun begeleiding ( $M=14.00 ; S D=3.24)$ dan asielzoekers $(M=10.84 ; S D=3.56)$.

- Het effect van het bezit van een verblijfsvergunning op rechtvaardigheid is significant: $\mathrm{t}(145)=3.90 ; \mathrm{p}=.0001$. (Ex-)vluchtelingen $(\mathrm{M}=22.64 ; \mathrm{SD}=6.45)$ ervaren hun begeleiding meer als rechtvaardig dan asielzoekers $(M=18.47 ; S D=6.19)$.

Hypothese 3 wordt hierdoor bevestigd. (Ex-)vluchtelingen zien meer kansen om door de begeleiding succesvol te kunnen integreren dan de asielzoekers. Daarnaast heeft de groep (ex-)vluchtelingen meer vertrouwen in begeleiding. Ze rapporteren meer inspraak in hun begeleiding en ze ervaren hun begeleiding meer als rechtvaardig dan de groep asielzoekers. De resultaten van de t-toets van de variabelen staan vermeld in bijlage 2 , tabel 4 .

\subsubsection{Hypothese 4}

Hypothese 4: de mate van depressie en psychopathologie van de respondenten is over het algemeen hoog. Asielzoekers ervaren meer last van diverse psychopathologische klachten dan (ex-)vluchtelingen.

Hieronder is eerst in tabel 10.2 een vergelijking gemaakt tussen de onderzoeksgroep en de gewone Nederlandse populatie. Voor de Beck-vragenlijst heb ik de normen van Bouman et al. (1985) gehanteerd. Voor de drie SCL-90-schalen heb ik gebruikgemaakt van de gehanteerde normen van Arrindell \& Ettema (1986) voor de normale Nederlandse populatie. Voor de vergelijkingen zijn de ruwe scores gebruikt en geen gecodeerde scores. 
Tabel 10.2 Vergelijking van de gegevens (1): gemiddelde, standaarddeviatie en p-waarde van de onderzoeksgroep en de normale populatie

\begin{tabular}{|c|c|c|c|c|c|}
\hline & $\begin{array}{l}\mathrm{m}(\mathrm{sd}) \\
\text { onderzoeksgroep } \\
\mathrm{N}=148\end{array}$ & $\begin{array}{l}\text { Normale } \\
\text { populatie } \\
\mathrm{N}\end{array}$ & $\begin{array}{l}M(s d) \\
\text { Normale } \\
\text { populatie }\end{array}$ & $t$ & $\begin{array}{l}\mathrm{p} \\
\text { Cohen's d }\end{array}$ \\
\hline $\mathrm{BDI}$ & $18.32(22.47)$ & 505 & $\begin{array}{l}2.28 \\
(3.5)\end{array}$ & $t(651)=15.44$ & $\begin{array}{l}P<0001 \\
d=1.44\end{array}$ \\
\hline $\begin{array}{l}\text { SCL: } \\
\text { totaal }\end{array}$ & $178.23(64.40)$ & 1053 & $\begin{array}{l}114.96 \\
(29.69)\end{array}$ & $t(1200)=20.00$ & $\begin{array}{l}\mathrm{p}<0001 \\
\mathrm{~d}=1.76\end{array}$ \\
\hline $\begin{array}{l}\text { SCL } \\
\text { DEP }\end{array}$ & $35.51(13.60)$ & 1052 & $\begin{array}{l}20.58 \\
(6.76)\end{array}$ & $t(1199)=21.42$ & $\begin{array}{l}\mathrm{p}<0001 \\
\mathrm{~d}=1.89\end{array}$ \\
\hline $\begin{array}{l}\mathrm{SCL} \\
\mathrm{ANG}\end{array}$ & $19.93(9.26)$ & 1052 & $\begin{array}{l}12.23 \\
(3.80)\end{array}$ & $t(1199)=18.18$ & $\begin{array}{l}\mathrm{p}<0001 \\
\mathrm{~d}=1.60\end{array}$ \\
\hline $\begin{array}{l}\mathrm{SCL} \\
\mathrm{AGO}\end{array}$ & $11.37(5.38)$ & 1052 & $\begin{array}{l}7.62 \\
(1.66)\end{array}$ & $t(1199)=17.46$ & $\begin{array}{l}\mathrm{p}<0001 \\
1.54\end{array}$ \\
\hline $\begin{array}{l}\mathrm{SCL} \\
\mathrm{SOM}\end{array}$ & $23.14(10.76)$ & 1051 & $\begin{array}{l}15.99 \\
(4.90)\end{array}$ & $t(1198)=14.04$ & $\begin{array}{l}\mathrm{p}<0001 \\
1.24\end{array}$ \\
\hline $\begin{array}{l}\mathrm{SCL} \\
\mathrm{SOM}\end{array}$ & $19.33(7.38)$ & 1051 & $\begin{array}{l}12.48 \\
(4.10)\end{array}$ & $t(1198)=16.82$ & $\begin{array}{l}\mathrm{p}<0001 \\
\mathrm{~d}=1.48\end{array}$ \\
\hline $\begin{array}{l}\text { SCL } \\
\text { SEN }\end{array}$ & $36.67(12.95)$ & 1052 & $\begin{array}{l}23.66 \\
(7.25)\end{array}$ & $t(1199)=18.10$ & $\begin{array}{l}\mathrm{p}<0001 \\
\mathrm{~d}=1.59\end{array}$ \\
\hline $\begin{array}{l}\mathrm{SCL} \\
\mathrm{HOS}\end{array}$ & $11.19(5.40)$ & 1052 & $\begin{array}{l}7.22 \\
(2.11)\end{array}$ & $t(1199)=16.50$ & $\begin{array}{l}\mathrm{p}<0001 \\
\mathrm{~d}=1.45\end{array}$ \\
\hline $\begin{array}{l}\text { SCL } \\
\text { SLA }\end{array}$ & $7.12(3.35)$ & 1052 & $\begin{array}{l}4.25 \\
(2.04)\end{array}$ & $t(1198)=14.53$ & $\begin{array}{l}\mathrm{p}<0001 \\
\mathrm{~d}=1.28\end{array}$ \\
\hline
\end{tabular}

Hierna is een overzicht gegeven van de scores van de respondenten op de psychopathologieschalen van de SCL-90 en de Beck Depressie-vragenlijst volgens de Nederlandse normen van respectievelijk Arrindell \& Ettema (1986) en Bouman et al. (1985). 
Tabel 10.3 SCL-90: de resultaten van de uitslagen van de respondenten $(\mathrm{N}=148)$

\begin{tabular}{|l|l|l|l|l|l|l|l|}
\hline SCL & $\begin{array}{l}\text { Zeer } \\
\text { laag }\end{array}$ & Laag & Ben-gem & Gem & $\begin{array}{l}\text { Boven- } \\
\text { gem }\end{array}$ & Hoog & $\begin{array}{l}\text { Zeer } \\
\text { hoog }\end{array}$ \\
\hline ANG & $6 \%$ & $5.4 \%$ & $7.4 \%$ & $4.7 \%$ & $24.4 \%$ & $19.5 \%$ & $32.6 \%$ \\
\hline AGO & $3.4 \%$ & $8.6 \%$ & $6 \%$ & $3.4 \%$ & $17.4 \%$ & $24.2 \%$ & $37 \%$ \\
\hline DEP & $2.7 \%$ & $1.3 \%$ & $2 \%$ & $6.7 \%$ & $9.4 \%$ & $30.2 \%$ & $47.7 \%$ \\
\hline SOM & $2.7 \%$ & $10.7 \%$ & $7.4 \%$ & $6 \%$ & $14 . \%$ & $31 \%$ & $28.2 \%$ \\
\hline INA & $2 \%$ & $4 \%$ & $6.7 \%$ & $12 \%$ & $7.5 \%$ & $26.8 \%$ & $41 . \%$ \\
\hline SENS & 0 & $1.3 \%$ & $2.7 \%$ & $17.4 \%$ & $10.1 \%$ & $20.8 \%$ & $47.7 \%$ \\
\hline HOS & $2 \%$ & $4.7 \%$ & $0.7 \%$ & $2.7 \%$ & $18.1 \%$ & $36.2 \%$ & $35.6 \%$ \\
\hline SLAAP & $2 \%$ & $6.7 \%$ & $2 \%$ & $10.7 \%$ & $16.8 \%$ & $32.9 \%$ & $28.9 \%$ \\
\hline Totaal & $2 \%$ & $4.1 \%$ & $3.4 \%$ & $5.4 \%$ & $13.5 \%$ & $25 \%$ & $46.6 \%$ \\
\hline
\end{tabular}

Tabel 10.4 Beck Depressie-vragenlijst: de resultaten van de uitslagen van de respondenten $(\mathrm{N}=148)$

\begin{tabular}{|l|l|l|l|l|l|}
\hline BDI & Geen & Laag & Gemiddeld & Hoog & Zeer hoog \\
\hline & $34.5 \%$ & $13.5 \%$ & $8.1 \%$ & $23.6 \%$ & $20.3 \%$ \\
\hline
\end{tabular}

Uit de bovenstaande tabellen blijkt dat de respondenten over het algemeen veel psychische en lichamelijke klachten rapporteren.

De mate van depressieve klachten van de hele groep is over het algemeen hoog.

Er is vervolgens een t-toets gebruikt om de verschillen tussen de twee groepen met en zonder verblijfsvergunning in kaart te brengen. Deze analyses zijn op de genormeerde scores uitgevoerd. Uit de analyses blijkt het volgende:

- Er bestaat een significant verschil tussen de twee groepen met betrekking tot depressieve klachten van de BDI: $\mathrm{t}(146)=4.16 ; \mathrm{p}<.0001$. Asielzoekers $(\mathrm{M}=3.34 ; \mathrm{SD}=1.46)$ hebben meer depressieve klachten dan (ex-)vluchtelingen $(M=2.31 ; S D=1.55)$.

- Er bestaat een significant verschil tussen de twee groepen met betrekking tot angstklachten: $\mathrm{t}(146)=2.50 ; \mathrm{p}=.014$. Asielzoekers ervaren meer angstklachten $(\mathrm{M}=5.84$; $\mathrm{SD}=1.41)$ dan (ex-)vluchtelingen $(M=5.23 ; \mathrm{SD}=1.56)$. 
- Er bestaat een significant verschil tussen de twee groepen met betrekking tot agorafobische klachten: $\mathrm{t}(146)=3.50 ; \mathrm{p}<0.01$. Asielzoekers $(\mathrm{M}=5.92 ; \mathrm{SD}=1.41)$ ervaren meer last dan (ex-)vluchtelingen ( $M=4.93 ; \mathrm{SD}=1.96)$.

- Er bestaat een significant verschil tussen de twee groepen met betrekking tot de slaapproblemen: $\mathrm{t}(146)=2.90 ; \mathrm{p}=.004$. Asielzoekers $(\mathrm{M}=5.85 ; \mathrm{SD}=1.22)$ ervaren meer slaapproblemen dan (ex-)vluchtelingen $(M=5.12 ; S D=1.74)$.

- Er bestaat een significant verschil tussen de twee groepen met betrekking tot algemene psychopathologische klachten: $\mathrm{t}(146)=2.30 ; \mathrm{p}=.019$. Asielzoekers $(\mathrm{M}=6.15 ; \mathrm{SD}$ $=1.39)$ ervaren meer psychopathologische klachten dan (ex-)vluchtelingen $(M=5.57$; $\mathrm{SD}=1.57)$.

Hypothese 4 wordt bevestigd. De resultaten van de toetsingen staan vermeld in bijlage 2 tabel 4.

\subsubsection{Hypothese 5}

Hypothese 5: er bestaat verschil tussen de twee groepen met betrekking tot de gehanteerde copingstijlen. Asielzoekers hanteren meer passieve en vermijdende coping dan (ex-) vluchtelingen.

Allereerst geef ik hieronder een overzicht van de gehanteerde copingstijlen van de respondenten, uitgedrukt in normscores volgens Schreurs et al. (1988).

Tabel 10.5 Utrechtse Copingvragenlijst (UCL): de resultaten van de uitslagen van de respondenten $(\mathrm{N}=148)$

\begin{tabular}{|l|l|l|l|l|l|}
\hline Coping & Zeer laag & Laag & Gemiddeld & Hoog & Zeer hoog \\
\hline AC & $5.4 \%$ & $23.6 \%$ & $46.6 \%$ & $17.6 \%$ & $6.8 \%$ \\
\hline PAL & $2.7 \%$ & $8.8 \%$ & $48.6 \%$ & $22.3 \%$ & $17.6 \%$ \\
\hline VER & $3.4 \%$ & $6.1 \%$ & $55.3 \%$ & $23 \%$ & $12.2 \%$ \\
\hline SOC & $4.7 \%$ & $10.2 \%$ & $52.7 \%$ & $20.9 \%$ & $11.5 \%$ \\
\hline PAS & $0 \%$ & $1.4 \%$ & $25 \%$ & $32.4 \%$ & $41.2 \%$ \\
\hline EXP & $3.4 \%$ & $5.4 \%$ & $55.4 \%$ & $28.4 \%$ & $7.4 \%$ \\
\hline GER & $0 \%$ & $4.7 \%$ & $47.3 \%$ & $23 \%$ & $25 \%$ \\
\hline
\end{tabular}

Uit de bovenstaande tabel blijkt dat respondenten over het algemeen flexibele copingstijlen hebben. Passieve coping is de enige uitzondering. $47 \%$ van de respondenten scoort hoog tot zeer hoog op de passieve coping. 
Om de verschillen tussen asielzoekers en (ex-)vluchtelingen in kaart te brengen zijn er t-toetsen uitgevoerd. Uit de analyses blijkt het volgende:

- Er bestaat een significant verschil tussen (ex-)vluchtelingen en asielzoekers met betrekking tot het toepassen van passieve coping: $\mathrm{t}(146)=3.15 ; \mathrm{p}<0.01$ ). Asielzoekers $(M=4.37 ; S D=0.73)$ passen meer passieve coping toe dan (ex-)vluchtelingen $(\mathrm{M}=3.93 ; \mathrm{SD}=0.87)$.

- $\quad$ r is een significant verschil tussen de twee groepen met betrekking tot het toepassen van afleiding zoekende (palliatieve) coping : $\mathrm{t}(148)=2.31 ; \mathrm{p}=.02$. Asielzoekers $(\mathrm{M}=3.62$; $\mathrm{SD}=0.95)$ passen vaker deze coping toe dan (ex-)vluchtelingen $(\mathrm{M}=3.25 ; \mathrm{SD}=0.96)$.

De resultaten voor alle copingstijlen staan vermeld in bijlage 2 tabel 4.

Hypothese 5 wordt gedeeltelijk bevestigd.

\subsubsection{Hypothese 6}

Hypothese 6: individuele en psychologische factoren hebben een modererend effect op de relatie tussen de kansperceptie en de begeleidingsfactoren.

Datacontrole met betrekking tot hypothese 6:

Uit de controle van de gegevens blijkt dat zowel de afhankelijke variabele (kansperceptie) als de begeleidingsvariabelen (rechtvaardigheid, vertrouwen, inspraak) alsook de modererende variabelen (depressie, copingstijlen, psychopathologie) van (quasi-)intervalniveau zijn. Geslacht en de verblijfsduur zijn bij de analyses ingevoerd als dummyvariabelen en moderatoren. Zowel de afhankelijke variabele kansperceptie als de onafhankelijke begeleidingsvariabelen hebben een normale verdeling. De Scatter Plots laten zien dat de verbanden tussen de afhankelijke variabele kansperceptie en de onafhankelijke variabelen lineair zijn. Er zijn geen extreme scores (outliers) gevonden.

Ter controle van multicollineariteit is er onderzocht of de variabelen onderling sterk met elkaar correleren. Een veel gehanteerde grenswaarde is .80 en hoger.

Zowel uit de literatuur (Leventhal, 1980; Leung \& Li, 1990) als uit controle blijkt dat de begeleidingsvariabelen onderling met elkaar hoog correleren. Uit de controle blijkt verder dat de mate van correlatie tussen de begeleidingsvariabelen niet hoger ligt dan .80 . Er is besloten om geen variabele uit de analyses te schrappen.

\section{Toetsing hypothese 6}

Om het effect van de modererende variabelen te onderzoeken, zijn er diverse regressieanalyses verricht. Daarnaast is gebruikgemaakt van variantieanalyses om een specifieker beeld te vormen van het interactie-effect.

De oorspronkelijke schalen voor variabele kans en de begeleidingsvariabelen zijn gehercodeerd zodat een hoge score ook een hoge mate van kans, respectievelijk tevredenheid, vertrouwen, inspraak en rechtvaardigheid representeert.

In eerste instantie is nagegaan of van de drie begeleidingsvariabelen een gezamenlijke supervariabele kan worden samengesteld. De bedoeling was om hiermee het aantal interactie-effecten te beperken. 
Door middel van een factoranalyse werd bekeken of het mogelijk was om de drie begeleidingsvariabelen te reduceren tot een supervariabele. Uit de factoranalyse blijkt dat er één factor aan de drie variabelen ten grondslag ligt welke $76 \%$ van de variantie verklaart (zie bijlage 5 Scree Plot 1). De Scree Plot laat zien dat er vanaf de tweede factor plotseling sterke daling in eigenwaarde optreedt en dat er slechts één factor is met eigenwaarde $>1$. De nieuwe variabele is tevredenheid genoemd.

Figuur 10.6 Scree Plot-1

SCREE PLOT

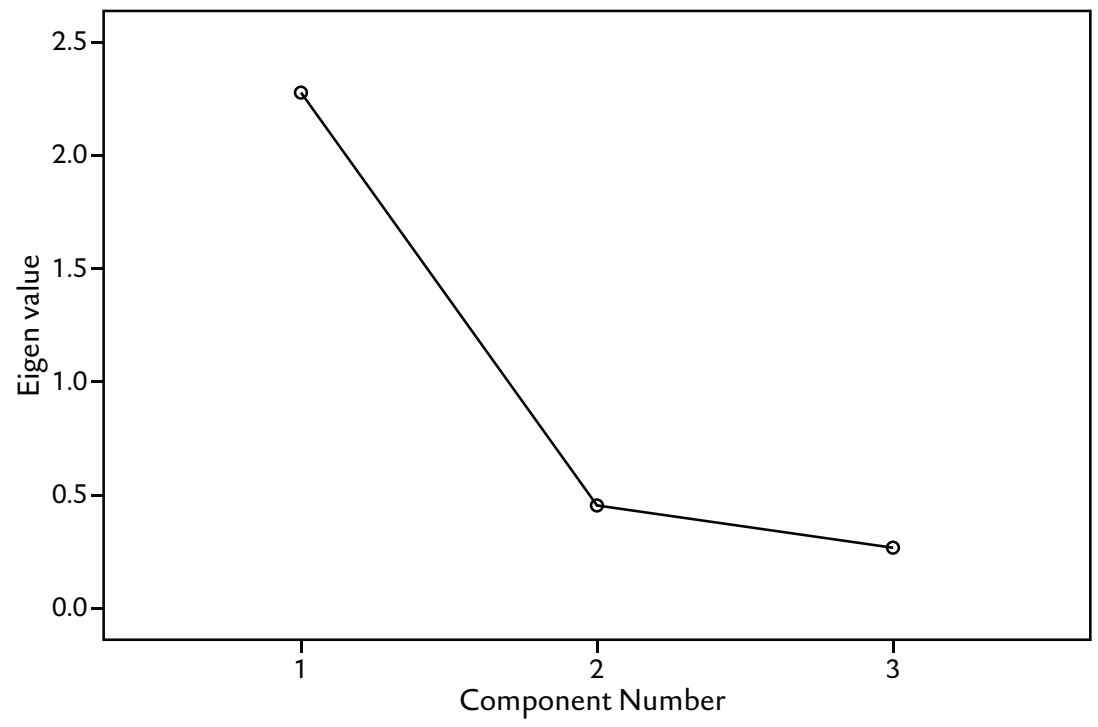

De resultaten staan vermeld in bijlage 5, figuur 1 .

Dezelfde stap is genomen voor de psychologische variabelen. De intentie was om na te gaan of het mogelijk is van deze variabelen een supervariabele te maken:

Door middel van een factoranalyse werd bekeken of het mogelijk is een reductie te maken van de psychologische moderatoren: depressie (de BDI-scores), algemene psychopathologie (totaalscore SCL-90) en de copingstijlen (7 schalen) tot een supervariabele. Een principale-componentenanalyse is uitgevoerd op de correlatie tussen de negen variabelen. Uit deze factoranalyse blijkt dat er drie factoren aan de variabelen ten grondslag liggen. De eerste factor verklaart 27,5\% van de variantie. De Beck-depressiescore, de totale psychopathologiescore van SCL-90 en passieve coping laden op deze factor. De tweede factor verklaart $24,4 \%$ van de variantie. Deze tweede factor bestaat uit actieve, palliatie- 
ve en vermijdende copingstijlen. De tweede factor heb ik actieve-gedragsmatige coping genoemd. De derde factor verklaart nog een extra 12,7\% van de variantie. Deze laatste factor bestaat uit sociale steun zoeken en expressie van gevoelens. Deze derde factor heb ik expressieve coping genoemd. De eerste groep van variabelen die gezamenlijk een supervariabele vormen heb ik psychopathologie genoemd (figuur 10.7).

Figuur 10.7 Scree Plot-2

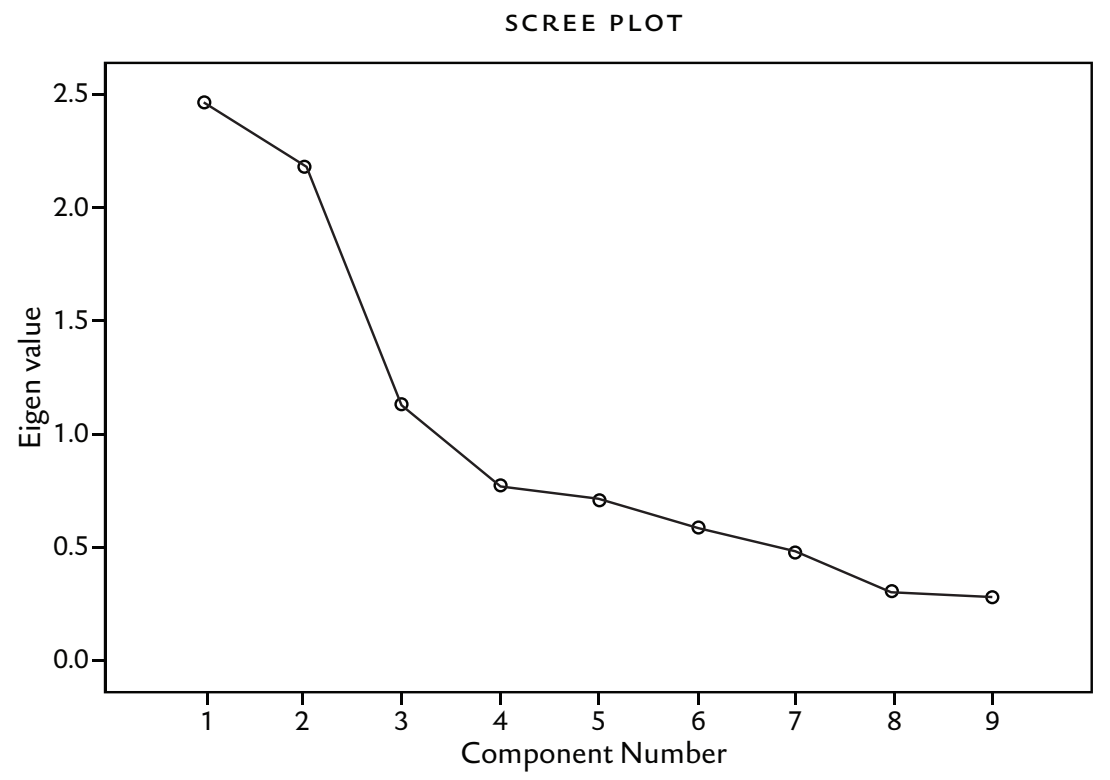

Met de nieuwe supervariabelen (bestaande uit gestandaardiseerde factorscores tevredenheid, gedragsmatige, expressieve coping en psychopathologie) zijn lineaire regressies uitgevoerd bestaande uit twee stappen om de hoofd-effecten en interactie-effecten met de nieuwe supervariabelen te onderzoeken.

Stap 1: er is nagegaan of de drie individuele variabelen (geslacht, leeftijd en het beschikken over een verblijfsvergunning) en de predictoren (tevredenheid, actief en gedragsmatige coping, expressieve coping en psychopathologie) hoofdeffect(en) hebben op de afhankelijke variabele kansperceptie.

Stap 2: bij deze stap zijn de interactie-effecten van zowel de individuele als de psychologische variabelen onderzocht met een voorwaartse procedure. Met deze stap kunnen we zien of er sprake is van een moderatie-effect. Uit de analyses blijkt dat er sprake is van een significant interactie-effect tussen tevredenheid en leeftijd. Uit de profiel plot blijkt verder dat jongere respondenten die weinig tevreden zijn over hun begeleiding, een lage- 
re kansperceptie hebben dan oudere respondenten die weinig tevreden zijn (zie figuur 10.10). De andere interacties worden niet in het model opgenomen, vanwege te hoge p-waardes (zie tabel 10.9).

Samenvatting van de resultaten van de variantieanalyse

Variantieanalyse met afhankelijke variabele kans en de twee onafhankelijke variabelen tevredenheid en psychopathologie toonde een significant effect aan voor tevredenheid: $\mathrm{t}(136)=6.592 ; \mathrm{p}<001$.

Op basis van de interactie-effecten is te concluderen dat de leeftijd de enige moderator is. Hypothesen over de moderatie-effecten van de andere variabelen, met name psychopathologie en copingstijlen, worden verworpen. 
Tabel 10.8 Regressieanalyse met kansperceptie als afhankelijke variabele, tevredenheid, actieve- gedragsmatige coping, expressieve coping en psychopathologie als onafhankelijke variabelen en het effect van verblijfsvergunning

\begin{tabular}{|l|c|c|c|c|}
\hline Variantiebron & B & $\begin{array}{c}\text { df1/df2 } \\
1 / 135\end{array}$ & t & p-waarde \\
\hline \multicolumn{5}{|l|}{ Stap1: Hoofdeffecten } \\
\hline Geslacht & .161 & & 2.210 & $.029^{*}$ \\
\hline leeftijd & .145 & & 1.933 & .055 \\
\hline Verblijf & -.036 & & .431 & .667 \\
\hline Tevredenheid & .515 & & 6.592 & $<.01^{*}$ \\
\hline Psychopathologie & -.085 & & 1.144 & .255 \\
\hline $\begin{array}{l}\text { Actieve, gedragsmatige } \\
\text { coping }\end{array}$ & -.153 & & 2.061 & $.041^{*}$ \\
\hline Expressieve coping & .009 & & .121 & .903 \\
\hline Stap2: Interactie- effecten & & & 2.589 & $.011^{*}$ \\
\hline Leeftijd x tevredenheid & -.760 & &
\end{tabular}

${ }^{*} p<.05 ;{ }^{* *} p<0.01$

Tabel 10.9 De overige interactie-effecten van de onafhankelijke variabelen met de variabele tevredenheid

\begin{tabular}{|l|l|l|}
\hline Interacties & $\mathbf{t}$ & $\mathrm{p}$-waarde \\
\hline Psychopathologie $\mathrm{x}$ tevredenheid & 1.361 & .176 \\
\hline Actieve-gedragsmatige coping $\mathrm{x}$ tevredenheid & -.140 & .889 \\
\hline Geslacht $x$ tevredenheid & .663 & .509 \\
\hline Verblijf $x$ tevredenheid & 1.406 & .162 \\
\hline Expressieve coping $x$ tevredenheid & .483 & .630 \\
\hline
\end{tabular}


Figuur 10.10 Profile Plot van de kansperceptie bij interactie-effect van leeftijd en tevredenheid

KANSPERCEPTIE OP POSITIEVERBETERING

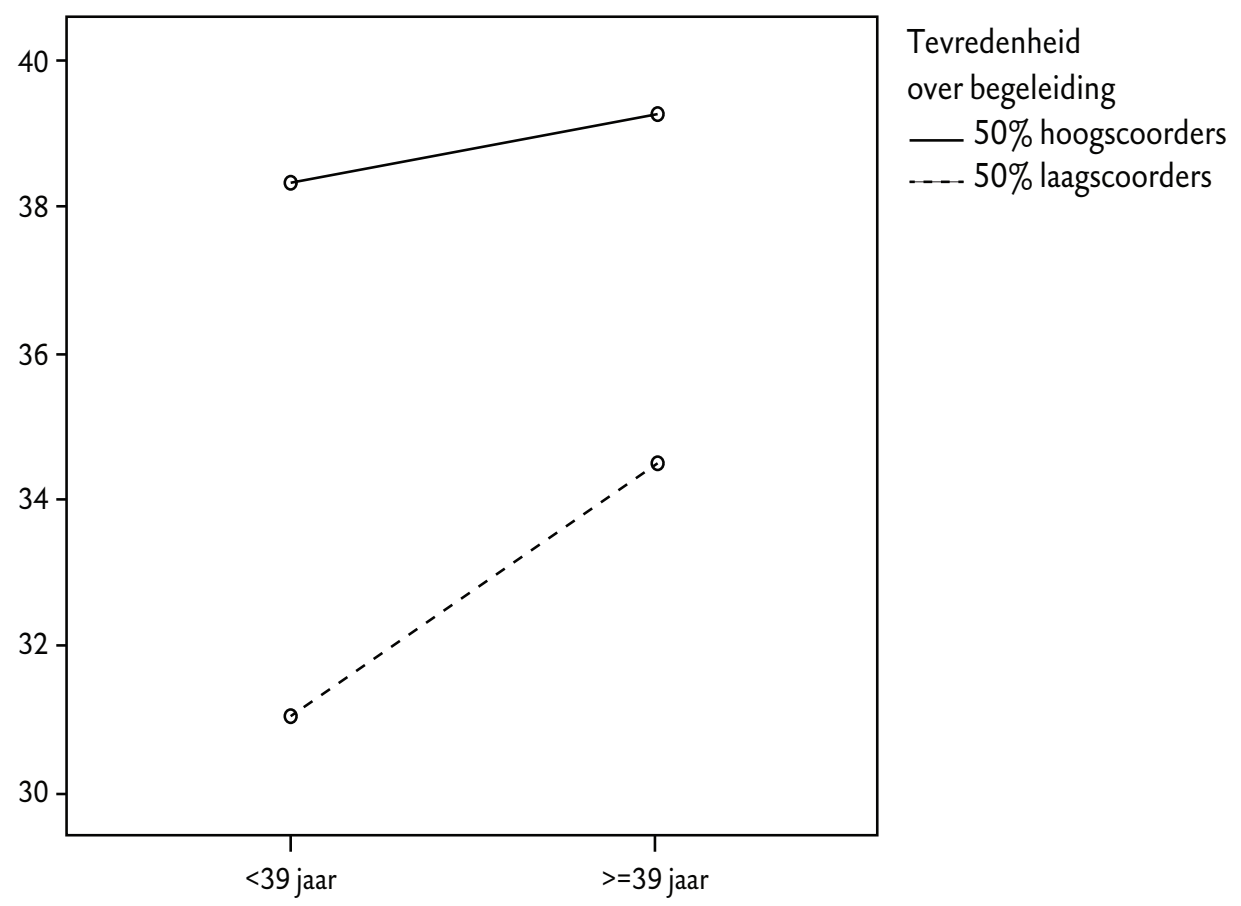

\subsubsection{Samenvatting}

In onderzoek 1 zijn vier vragenlijsten toegepast waaronder een zelfontworpen begeleidingsvragenlijst. Respondenten bestonden uit asielzoekers zonder een verblijfsvergunning en (ex-)vluchtelingen met een permanente verblijfsvergunning. Het effect van begeleidingsvariabelen op de kansperceptie van respondenten stond in onderzoek 1 centraal. Daarnaast is het modererend effect van individuele en psychologische variabelen op de relatie tussen kansperceptie en tevredenheid over begeleiding onderzocht. De belangrijkste uitkomsten van onderzoek 1 kan ik als volgt samenvatten:

- De meerderheid van de respondenten is enigszins tot sterk ervan overtuigd dat door de begeleiding zijn/haar kans op positieverbetering stijgt.

- Asielzoekers hebben minder dan degenen met verblijfsvergunning vertrouwen in begeleiding, voelen weinig inspraak in hun begeleiding en ze beoordelen het proces van begeleiding als minder rechtvaardig.

- Asielzoekers zien minder kansen om succesvol te kunnen integreren dan (ex-) vluchtelingen. 
- Tevredenheid over de begeleiding heeft een positieve relatie met kansperceptie.

- Actieve- gedragsmatige coping heeft een negatieve relatie met kansperceptie.

- Mannen zien meer kansen om succesvol te kunnen integreren dan vrouwen.

- Er bestaan negatieve correlaties tussen diverse psychopathologievariabelen en kansperceptie.

- Leeftijd modereert de relatie tussen tevredenheid en kansperceptie. Bij jongere respondenten is er een groter effect van tevredenheid over integratie op kansperceptie dan bij oudere respondenten.

\subsection{Onderzoek 2: diepte-interviews}

De resultaten van de explorerende vragen worden hierna weergegeven. Per cluster wordt een overzicht gegeven van de antwoorden van de geïnterviewden op de vragen. ledere cluster is afgesloten met een conclusie.

\subsubsection{Cluster 1: Definitie en betekenis van integratie}

De volgende vragen maken deel uit van deze cluster:

- Welke betekenis geven de respondenten aan het woord integratie?

- Wat beweegt de respondenten om te gaan/willen integreren?

- Welke factoren hebben in zowel positieve dan wel negatieve zin effect op hun integratie?

- Denkt respondent dat hij/zij geïntegreerd is, en zo ja, waarom?

Er zijn vier elementen te onderscheiden in de verschillende beschrijvingen van de integratie:

Voor de meeste respondenten betekent integratie: gemakkelijk en effectief omgaan en communiceren met autochtonen. Centraal staat hier het sociale en communicatieve element. Daarnaast betekent integratie het accepteren van normen en waarden van de Nederlandse samenleving en het zich daarbij aanpassen, dus het kunnen omgaan met normen en waarden in deze cultuur. Het normatieve element staat bij deze betekenisgeving centraal. Het derde element is instrumenteel en heeft te maken met praktische kennis van de Nederlandse samenleving, waaronder het beheersen van de Nederlandse taal en een betaalde baan. Bij het vierde element staan de eigenschappen van het individu centraal: zelfstandig kunnen functioneren, flexibel zijn, assertief zijn en onafhankelijk en autonoom kunnen handelen. Het resultaat van integratie is dat de persoon zich uiteindelijk goed thuis kan voelen en geen heimwee heeft. Sommige respondenten maken een duidelijk onderscheid tussen assimilatie en integratie.

In de definitie die respondent 6 van integratie geeft, zien we dit onderscheid: 'Ik kan niet alle aspecten van de Nederlandse cultuur accepteren. Normen en waarden van mijn eigen cultuur wil ik ook behouden. Anders heb ik het gevoel dat ik niet meer mezelf ben. Ik wil mijn eigen culturele normen ook houden.' 
Respondent 17 geeft de volgende definitie van integratie: 'Integratie is goed kunnen communiceren en gemakkelijk omgaan met de normen en waarden van de andere cultuur. Anders kom je terecht in een gettosituatie. Je kunt niet veel bereiken als je met de mensen van een ander land niet kunt communiceren. Als je de taal niet goed spreekt, kun je weinig bereiken. Taal speelt een zeer belangrijke rol bij integratie.'

Respondent 2 ziet assertiviteit en flexibiliteit als de twee belangrijkste factoren voor een succesvolle integratie: 'Je moet durven en niet bang zijn. De taal leer je als je je niet terugtrekt van Nederlanders. Je moet durven deelnemen aan de maatschappelijke activiteiten.'

Respondent 16 ziet integratie als: 'Goed kunnen communiceren en accepteren van de normen en waarden van de andere cultuur, anders kom je in een geïsoleerde situatie terecht.'

Behalve de gemeenschappelijke lijn bestaat er ook verschil tussen de asielzoekers en de (ex-)vluchtelingen over de wijze waarop ze integratie definiëren. Voor (ex-)vluchtelingen is integratie een tweezijdige weg: interactie tussen allochtonen en autochtonen en over en weer elkaar beïnvloeden. Je leert niet alleen van de bevolking van het gastland, maar je beïnvloedt ze ook op een actieve manier. Het is een dynamische wisselwerking tussen de twee groeperingen. Centraal staat hier dus het element gelijkheid.

Voor de asielzoekers lijkt integratie meer een eenzijdig proces te zijn. Respondent 16 vertelt: In een nieuw land leer je van de cultuur en je past je aan bij de normen en waarden van het gastland. Integratie is het proces van acceptatie en zich laten beïnvloeden door de bevolking van het nieuwe land. Nederlanders dragen bijvoorbeeld geen hoofddoeken, volgens mij zijn ze daar gevoelig voor. Het dragen van een hoofddoek betekent voor hen niet geïntegreerd zijn. Dat moet je dus niet doen.'

Daarnaast zien we dat bijna iedereen op een objectieve wijze de instrumentele functie van integratie benadrukt. Het beheersen van de Nederlandse taal is door 11 van de respondenten gezien als het belangrijkste instrument voor een succesvolle integratie. Daarnaast vinden respondenten 'werken' een belangrijke factor, waardoor de integratie wordt bevorderd.

\subsubsection{Conclusie cluster 1}

Respondenten geven een zeer gevarieerde betekenis aan het woord integratie. Deze betekenissen kunnen we verdelen in vier categorieën:

- sociaal-communicatieve betekenis

- normatieve betekenis

- individueel gerelateerde betekenis (onafhankelijkheid, assertief, autonoom)

- sterk instrumentele betekenis (taal en werk)

Verder maken respondenten expliciet en impliciet onderscheid tussen assimilatie en integratie.

Vrijwel iedereen benadrukt de instrumentele functie van integratie. Dat wil zeggen dat integratie in termen van praktische resultaten wordt gezien. Het beheersen van de Neder- 
landse taal wordt door 11 respondenten gezien als het belangrijkste instrument voor een goede integratie. Daarnaast zien 5 respondenten taal en werk als de belangrijkste instrumenten. Twee respondenten zien individuele eigenschappen als de doorslaggevende factor voor een goede integratie. Verder is men over het algemeen van mening dat de begeleiding zich beperkt tot praktische en instrumentele begeleiding. Op normatief en sociaal-communicatief niveau ervaart men weinig begeleiding.

\subsubsection{Cluster 2: De rol van begeleiding}

De volgende vragen maken deel uit van deze cluster:

- Welke rol speelt de formele/informele begeleiding bij een succesvolle integratie?

- Welke specifieke aspecten van de begeleiding vinden de respondenten van belang voor een geslaagde integratie?

- Hoe beleven de respondenten de formele/informele begeleiding die ze hebben gehad?

- Hebben de respondenten het gevoel dat ze door de formele begeleiding meer kansen maken in Nederland?

Bijna alle respondenten zijn van mening dat begeleiding onmisbaar is voor het integratieproces. Begeleiding heeft diverse functies: een goede begeleiding creëert hoop, versnelt het proces van integratie, is energiebesparend en zorgt ervoor dat men gericht kan werken en minder tijd verliest.

Ondanks het feit dat iedereen begeleiding zeer belangrijk vindt voor het proces van integratie, bestaat er een discrepantie tussen wat respondenten als begeleiding wenselijk vinden en wat ze in de praktijk hebben meegemaakt. Respondenten onderscheiden op basis van hun eigen ervaring twee soorten begeleiding: formele begeleiding die door diverse maatschappelijke instanties wordt gegeven en informele begeleiding die men in zijn dagelijks leven ontvangt. Voorbeelden van formele instanties zijn: het COA (Centraal Orgaan opvang asielzoekers) en de MOA (Medische Opvang Asielzoekers), twee instanties die tijdens de asielprocedure begeleiding van asielzoekers op zich nemen. Nadat men een verblijfsvergunning heeft verworven, krijgt men begeleiding op het gebied van scholing en werk. Deze begeleiding wordt gegeven door onder andere de Sociale Dienst, ROC-instanties en het Centrum van Werk en Inkomen (CWI).

Informele begeleiding komt vooral tot stand door contacten met kerken, vrijwilligers die actief zijn in asielzoekerscentra, Nederlandse kennissen en vrienden, landgenoten die al langer in Nederland wonen en de Nederlandse klasgenoten.

Respondent 6 schrijft bijvoorbeeld zijn successen toe aan zijn ex-vriendin. Hij heeft geen begeleiding gekregen van de formele instellingen: 'Mijn ex-vriendin was mijn begeleidster. Ik heb alles aan haar te danken. De taal heb ik van haar geleerd. Ze heeft me ook geholpen bij het vinden van een baan. De sociale dienst en het arbeidsbureau had ik gelukkig niet nodig. Maar niet iedereen heeft zoveel geluk gehad als ik.'

Respondenten maken tevens een onderscheid tussen het systeem van begeleiding en 
de begeleider als persoon. Het gaat vooral om de interactie tussen twee mensen. Met het systeem van formele begeleiding heeft men over het algemeen niet zoveel positieve ervaring. De rol van 'de begeleider' is belangrijker dan het systeem. Een goede begeleider is persoonlijk betrokken bij zijn/haar cliënt en kan zich de situatie van de vluchteling voorstellen. Respondenten zien het systeem van de formele begeleiding als bureaucratisch en beperkend. Tevens zien de geïnterviewden verschillen tussen de begeleiders onderling.

Respondent 5 zegt: 'Er is duidelijk verschil tussen begeleiders. Ik ben echt hiervan overtuigd. Je moet een beetje geluk hebben en de juiste begeleider tegenkomen.'

Zowel asielzoekers als (ex-)vluchtelingen zijn van mening dat ze weinig begeleiding hebben ontvangen van de maatschappelijke instanties. Wat hen vooral veel geholpen heeft, is informele begeleiding die spontaan tot stand komt. Deze vorm van begeleiding kent geen eigenbelang. Een Nederlandse klasgenote, een goede vriend, die emotionele banden heeft met vluchtelingen, een lieve oude vrouw die in de kerk actief is en iedereen die zich op basis van persoonlijke motieven bij asielzoekers en vluchtelingen betrokken voelt. Daar ligt volgens hen de basis voor een succesvolle integratie.

Respondent 16 heeft vooral veel emotionele hulp en ondersteuning gehad van zijn kennissen die betrokken zijn bij de kerken: 'Ze hebben mij en mijn gezin altijd ondersteund. Je hebt het gevoel dat er mensen zijn die om je geven. Het feit dat ze geen eigenbelang hebben en je niet beschouwen als een minderwaardige. De emotionele ondersteuning van deze groep mensen heeft me geholpen om de hoop niet te verliezen.'

Respondenten zijn van mening dat de rol van de persoon zelf net zo belangrijk is als de vorm en de inhoud van de begeleiding.

Over het algemeen zijn asielzoekers van mening dat ze weinig begeleiding hebben gekregen van de formele instanties.

Op één ex-vluchteling na is de rest van de vluchtelingen van mening dat ze geïntegreerd zijn mede door hun begeleiding. Begeleiding kan het integratieproces versnellen. Het effect van de begeleiding is volgens de respondenten vooral procesmatig. Daarnaast achten de respondenten de informele begeleiding net zo belangrijk als de formele begeleiding. Emotionele steun, betrokkenheid en geen eigenbelang hebben benoemen respondenten als de positieve aspecten van informele begeleiding. Respondenten beschouwen informele begeleiding als gelijkwaardig. Dat is in tegenstelling tot formele begeleiding die verder weg staat en zakelijk is. De rol van de formele begeleiding is beperkt: beperkt door de bureaucratie, beperkt door normen en waarden van de formele begeleiding en de hulpverleners, beperkt door beperkte sociale contacten, beperkt door het optreden van de begeleiders (zakelijk, op zichzelf gericht en assertief, en niet gelijkwaardig). Het instrumentele aspect van de begeleiding zien de respondenten als zeer belangrijk, zichtbaar en praktisch omdat dit hen verder in staat stelt om de wegen in de ingewikkelde Nederlandse samenleving te vinden. Voor zover men inzicht krijgt in de normatieve en sociaal-communicatieve aspecten, is dat men leert dat Nederland bureaucratisch is. Normen en waarden voldoen aan regels die opgelegd zijn en dus anoniem schijnen. Men leert dat assertiviteit en onafhankelijkheid cruciaal zijn en dat de begeleiders zelf gericht zijn op hun eigenbe- 
lang. Want het begeleiden doen ze in het kader van hun baan. Dit is, zo zien de respondenten het, verre van betrokken.

De rol van informele begeleiding is veel breder: men leert daardoor de Nederlandse normen en waarden kennen. Men heeft meer gevarieerde contacten. Men ziet dat Nederlanders behulpzaam en betrokken zijn en niet op zichzelf gericht zijn.

De rol van de formele begeleiding kan op verschillende punten vergeleken worden met die van de informele begeleiding. Informele begeleiding verschilt van de formele in de volgende aspecten:

- Gelijkwaardigheid (respondent is vrij en heeft keuzevrijheid).

- Emotionele steun en betrokkenheid.

- Belangeloosheid.

Een belangrijk verschilpunt tussen informele en formele begeleiding is verder de mate van verbondenheid en hechting. Verbondenheid is een belangrijk aspect van informele begeleiding. Respondenten benadrukken dat ze zich emotioneel gemakkelijker kunnen hechten aan hun informele begeleiders.

\section{Begeleiding, hechting en verbondenheid}

Vluchtelingen en asielzoekers zijn onvrijwillige migranten. Ze verlaten hun huis door levens- en/of vrijheidsbedreigingen. Bij asielzoekers en vluchtelingen is er sprake van een 'cyclus van verlies': hun oorspronkelijke gemeenschap is uiteengevallen waarna ze een vluchtgemeenschap vormden. Ze komen uiteindelijk in een volledig nieuwe en ook vreemde gemeenschap terecht. Dat betekent zich opnieuw kunnen hechten en zich wortelen in een nieuwe wereld. ledere asielzoeker dient uiteindelijk vrede te sluiten met zijn/ haar verleden en een evenwicht te vinden in het heden.

Vlucht betekent 'onthechting'. Dat betekent ook dat het vaderland dat ze achter zich hebben gelaten niet voldoende sterk en/of betrouwbaar was om zijn individuen te beschermen. Vlucht betekent verlies en onthechting, maar tegelijkertijd ook het zoeken naar verbinding en hechting in het nieuwe land. Naar mijn mening speelt 'hechtingservaring' een belangrijke rol bij een succesvol integratieproces.

De basis van het merendeel van onze ontwikkelingen bestaat uit het concept 'hechting'. Hechting verwijst naar de emotionele banden die we hebben met andere mensen, maar ook met cultuur, omgeving enzovoort.

In de literatuur wordt met het woord hechting vooral de wederzijdse band tussen het kind en zijn ouders bedoeld. Hechten is een biologisch bepaalde drijfveer en van even groot belang als de zuigreflex. Zonder hechting en hechtingsgedrag kunnen kinderen niet overleven, evenmin als veel andere jonge dieren. Voor mens en dier betekent dit dicht bij de moeder blijven in situaties van dreiging. Het doel van hechting is volgens Bowlby (1969) dat men gaat beschikken over zelfvertrouwen en vertrouwen in anderen. Veel van de emotionele ontwikkeling van een kind is geworteld in de relaties met zijn vroegere primaire verzorgers. Als de relatie met de opvoeders positief is, reguleren de cognitieve 
structuren van het kind de emoties op een positieve manier. Een negatieve relatie kan het gebruik van emotionele en cognitieve capaciteiten belemmeren (Kraemer, 1992). Een goede hechting stelt personen in staat met anderen samen te werken (Van IJzendoorn \& Miedema, 1986).

De grondlegger van de hechtingstheorie is John Bowlby. Hij heeft een onderscheid gemaakt tussen veilige en onveilige hechting tussen het kind en zijn primaire zorgfiguren (Bowlby, 1969). De kwaliteit van hechtingservaring vormt volgens Bowlby de basis voor het psychisch functioneren op latere leeftijd.

Een veilige hechting komt tot stand als ouders sensitief en responsief reageren op signalen van het kind. Dit vormt de basis voor een stabiel emotioneel en cognitief functioneren in het volwassen leven. Sensitiviteit van de primaire verzorger leidt tot vertrouwen. Dat betekent dat de hechtingsfiguren bereikbaar en beschikbaar zijn. Daardoor slaagt het kind erin om vertrouwen in zichzelf en in de anderen te ontwikkelen.

Hechting heeft ook potentieel effect op het ontwikkelen van sociale cognitie. Sociale cognitie is de capaciteit waarmee mensen hun relaties met anderen begrijpen. Als deze capaciteit slecht ontwikkeld is, kunnen mensen veel sociale interacties als stressvol of onbekend ervaren. Dit heeft volgens Kraemer (1992) vooral te maken met een niet goed ontwikkelde innerlijke representatie van de persoon. De kwaliteit van hechting in de vroege kindertijd bepaalt dus het ervaren van verbondenheid als volwassene.

Het begrip verbondenheid ligt in het verlengde van hechting. ledereen streeft naar verbondenheid. Verbondenheid bestaat uit de behoefte om bij anderen te horen en voor hen van betekenis te zijn, de behoefte om samen te zijn en verzorgd te worden en voor anderen te zorgen. ledereen is steeds bezig met het vinden van een evenwicht tussen zelfstandigheid en verbondenheid.

Uit het interview met respondenten komt duidelijk naar voren dat ze een onderscheid maken tussen de formele en informele begeleiding.

Over het algemeen zijn respondenten van mening dat ze vooral baat hebben gehad bij informele begeleiding. Deze begeleiding beschrijven ze als betrokken, zorgzaam en warm. Begeleiding die niet op eigenbelang gebaseerd is, sociale en emotionele steun biedt en geïnteresseerd is in de asielzoeker als medemens.

Vluchtelingen hebben behoefte aan verbondenheid en hechting met hun omgeving. Het leven in het nieuwe land en zich wortelen kunnen we vergelijken met het hechtingsproces dat een kind doorloopt om basisvertrouwen te ontwikkelen. Begeleiding kan volgens respondenten dit proces vergemakkelijken of juist belemmeren.

De opgave om een nieuw bestaan op te bouwen confronteert vluchtelingen met diverse crisissen. Hun emotionele weerbaarheid en evenwicht wordt keer op keer op de proef gesteld. Een evenwicht vinden tussen het verleden en heden betekent ook kunnen omgaan met een cultuurshock. Het uitvallen van het emotionele steunsysteem in combinatie met vluchten doet een appel op het evenwicht en de weerstand van vluchtelingen. Een goede begeleiding heeft een direct effect op het ontwikkelen van het gevoel van verbondenheid. Daarnaast heeft iedere asielzoeker zijn/haar eigen hechtingsgeschiedenis. 
Informele begeleiding vervult symbolisch gezien de rol van een ouderlijk figuur die warmte en veiligheid uitstraalt en betrouwbaar is: een veilige bron, waarop een vluchteling kan rekenen. De twee belangrijkste aspecten van een goede hechting, responsiviteit en sensitiviteit, vinden respondenten terug bij informele begeleiding. Met sensitiviteit en responsiviteit bedoel ik de signalen op tijd opmerken en vervolgens deze juist interpreteren en daarop willen en kunnen reageren.

Uit de interviews met de asielzoekers komt naar voren dat ze een bijzondere waarde hechten aan informele begeleiding, en een negatief beeld hebben van formele begeleiding. Het kenmerk van informele begeleiding is volgens asielzoekers vooral 'hechting'. De respondenten zien 'onthechting' als een belangrijk kenmerk van formele begeleiding en vooral asielzoekers beschrijven formele begeleiding als afstandelijk en zakelijk. Responsiviteit en sensitiviteit ontbreken volgens de respondenten aan de formele begeleiding. Het gebrek aan vertrouwen en veiligheid leidt tot kwetsbaarheid, boosheid en vervolgens tot vervreemding van de gemeenschap.

Van de sociaal-communicatieve aspecten benoemen respondenten zaken als: goed luisteren, gerichte informatie geven, rekening houden met behoeften en de achtergrond van asielzoekers en vluchtelingen.

Een goede begeleider moet zijn/haar vak goed kennen en respondenten gerichte en relevante informatie geven. De begeleider dient betrokken te zijn bij de asielzoeker/ vluchteling.

Respondent 14 is sinds kort uitgeprocedeerd. Ze vindt de manier waarop veel van de COA-medewerkers met asielzoekers omgaan afstandelijk, kortzichtig, puur zakelijk en niet eerlijk.

Respondent 12 vertelt: 'Een goede begeleider dient betrokken te zijn bij ons. Eerst moet je in de ogen van je begeleider een gelijkwaardig mens zijn. Dat gevoel heb ik niet gehad. Voor de medewerkers van het COA zijn we niet meer dan cijfers en getallen. Communiceren op een gelijkwaardige manier is echt een illusie. Men vergeet dat we in Iran een bepaalde status hadden. We zijn niet minder en we zijn ook niet zielig.'

Een belangrijk aspect voor een goede begeleiding is het geven van gerichte, duidelijke en relevante informatie. De begeleider dient zijn vak goed te kennen en weet te hebben van de bestaande mogelijkheden.

Zo definieert respondent 8 de aspecten van een goede begeleiding als volgt: 'Een goede begeleider moet weten wat voor mogelijkheden er bestaan. Bovendien moet hij ook op tijd bemiddelen. Vooral op gebieden als scholing en werk is dit zeer belangrijk, anders komen vluchtelingen door veel gissen en gokken nog meer in de war. Ik heb veel tijd verloren door onwetendheid van mezelf en fouten van mijn begeleider.'

Het weet hebben van de culturele achtergrond van vluchtelingen en mensenkennis vindt respondent 13 de twee belangrijkste aspecten die bij een goede begeleiding horen.

'leder persoon is anders en dat heeft niet echt te maken met een bepaalde cultuur. Toch is kennis hebben van onze culturele achtergrond zeer belangrijk en heeft dit effect op de wijze waarop we ons hier gedragen en met mensen omgaan. We zitten anders in elkaar, 
denk ik, dan Nederlanders. We zijn bijvoorbeeld emotioneler en we reageren ook emotioneler. Voor ons zijn vriendschap en idealen zeer belangrijk. Ook merk ik dat rechtvaardigheid voor ons belangrijker is dan voor Nederlanders. Een Nederlandse begeleider is over het algemeen minder emotioneel en doet alleen maar zijn werk. Wat we nodig hebben is betrokkenheid. Daarnaast kan het cultuurverschil tot miscommunicatie leiden. Ik denk dat de begeleiders kennis moeten nemen van onze culturele normen en waarden. Anders zijn ze eenzijdig met hun eigen mening over ons bezig en dat vind ik fout.'

De drie begeleidingsfactoren komen regelmatig terug in de beschrijvingen die respondenten geven van een goede begeleiding. Daarnaast benadrukken respondenten dat 'cultuurverschil' tot misverstanden zou kunnen leiden. Om de verschillen te kunnen overbruggen, is het wenselijk dat de begeleider enige kennis heeft van de culturele achtergrond van zijn respondent. Dit is een basisvoorwaarde voor een goede wisselwerking tussen begeleider en vluchteling.

Een ander belangrijk aspect is het verkrijgen van goede en gerichte informatie. Respondenten wensen daarnaast een rechtvaardige en eerlijke manier van communicatie en interactie met hun begeleiders. Ze wensen dat er naar hen geluisterd wordt en dat er rekening gehouden wordt met hun persoonlijke omstandigheden, wensen en behoeften. Dit betekent ook dat de vluchteling inspraak heeft en hij invloed kan uitoefenen op zijn eigen lot en leven. Een zakelijke en afstandelijke houding benoemen respondenten als slecht voor een goede begeleiding.

(Ex-)vluchtelingen schrijven hun kansen toe aan eigen inzet aan de ene kant en informele begeleiding aan de andere kant. Vluchtelingen die zich assertief en actief opstellen, nemen de regie in eigen handen en ze bereiken daardoor meer succes. Steun van de Nederlandse kennissen en vriendenkring is onmisbaar voor een succesvolle integratie. Hier benadrukken de respondenten het belang van het sociaal-communicatieve aspect van integratie.

Respondent 2 benadrukt dat zij door de formele begeleiding veel kansen heeft gemist: 'Na tien jaar heb ik mijn opleiding niet kunnen afronden. Ik heb vanaf de eerste periode duidelijk aangegeven dat ik de opleiding boekhouding wilde volgen. Dat was mijn vak in Iran en daar heb ik jarenlang ervaring mee opgedaan. Men wilde me niet geloven en heeft mij de kans niet gegeven. Mijn begeleider wist het namelijk altijd beter wat goed voor mij is. Ik moest de opleiding administratie volgen. Uiteindelijk is ze ermee akkoord gegaan en momenteel volg ik de opleiding boekhouding, belachelijk. Nu ben ik tien jaar verder en ouder en ik heb weinig energie, kracht en motivatie. Eerlijk gezegd, het interesseert me ook niet. Mijn kansen zijn alleen maar verminderd door haar begeleiding.'

Alle 9 asielzoekers zijn van mening dat er geen begeleiding bestaat tijdens de asielprocedure. Degenen die nog niet uitgeprocedeerd zijn, mogen de Nederlandse taal (beperkt) leren en ze mogen drie maanden werken. Uitgeprocedeerde asielzoekers worden uit alle voorzieningen gezet.

Respondent 17 was verbaasd en reageerde met boosheid: 'Er bestaat geen begeleiding. Ons leven in Nederland begint vanaf het moment dat we een verblijfsvergunning 
bemachtigen. Vóór die tijd en in het azc, verspil je je tijd. Wat we regelmatig doen is thee en koffie drinken en roken. Verder volgen we iedere dag het nieuws. ledere dag beginnen en beëindigen we met angst.'

Respondent 19 heeft alles wat ze tot heden bereikt heeft te danken aan een paar goede Nederlandse kennissen. Daarnaast heeft ze van de Stichting voor Vluchteling-Studenten (UAF) de kans gekregen om te studeren:'Je moet hier voor je bestaan knokken. Ik vraag me af of ik ooit rust kan hebben. Als vluchteling moet je voortdurend vechten voor je bestaan. Ik heb via UAF de mogelijkheid gekregen om te studeren. In september zal ik beginnen met een HBO-studie. Mijn begeleider bij UAF regelt praktische dingen voor mij. Door deze studie hoop ik dat ik meer kansen kan krijgen in Nederland.'

Respondent 8 kon na het afronden van zijn studie heel gauw werk vinden. Dit is hem gelukt door zijn samenwerking en goede interactie met zijn begeleider: 'Mijn begeleider vroeg me altijd wat ik wilde en onderzocht wat mogelijk was. Ik had het gevoel dat hij goed naar me heeft geluisterd. Hij heeft niet voor mij willen bepalen wat ik moest doen. Door goede samenwerking ging alles heel soepel. Hij gaf me ook complimenten en daardoor gaf hij mij ook een beter zelfvertrouwen. Ik denk dat ik door zijn begeleiding goede kansen heb gekregen in Nederland.'

\subsubsection{Conclusie cluster 2}

Respondenten schrijven hun successen toe aan eigen persoonlijke inzet, motivatie en doorzettingsvermogen. Daarnaast waarderen ze de rol van informele begeleiding. Formele begeleiding wordt niet altijd gezien als motiverend en positief. Naar de mening van sommige respondenten heeft de formele begeleiding hun kansen in Nederland juist verminderd. Dat schrijft men vooral toe aan aspecten als gebrek aan goede communicatie, onderschatten van kennis en de werkervaring van de respondenten in hun vaderland, het volgen van opleidingen die niet aansluiten bij de genoten opleiding en opgedane ervaringen in Iran. Men heeft wel vertrouwen in informele begeleiding.

Volgens de attributietheorie proberen mensen orde in hun sociale waarneming te brengen door het gedrag en de gebeurtenissen toe te schrijven aan bepaalde aspecten in een relatief stabiele omgeving, namelijk aan de omstandigheden (een situationele attributie) ofwel aan een kenmerk (emotie, trek, motief) van henzelf of van anderen.

Volgens de sociale psychologie zijn we geneigd om onze successen toe te schrijven aan onszelf (intern) en mislukking aan de omstandigheden (extern).

Er zijn twee verklaringen voor deze 'vertekening in eigen voordeel'.

Volgens de cognitieve verklaring zijn mensen over het algemeen geneigd om positieve en hoopvolle gedachten over de resultaten van hun eigen gedrag te koesteren en de positieve uitkomsten worden vaak toegeschreven aan interne factoren (eigen kwaliteit en gedrag).

De motivationele verklaring is gebaseerd op de gedachte dat onze positieve zelfachting ermee gediend is wanneer we positief bij anderen overkomen.

Het toeschrijven van succes aan onszelf en falen aan omstandigheden buiten onszelf komt direct ons zelfrespect ten goede. Dit reduceert de cognitieve dissonantie en leidt tot consonante cognities (Festinger, 1957). 
Het lijkt erop dat respondenten hun succeservaringen vooral intern attribueren (eigen inzet en motivatie), terwijl zij hun faalervaringen vooral aan hun formele begeleiding toeschrijven. Het feit dat respondenten echter zo complimenteus zijn over hun informele begeleiding geeft aan dat een simpele 'self-serving' attributiebias een onvoldoende verklaring biedt voor hun negatieve kwalificaties van de formele begeleiding.

\subsubsection{Cluster 3: De rol van de begeleidingsvariabelen}

De volgende vragen maken deel uit van deze cluster:

- Welke kenmerken van het systeem van begeleiding en/of begeleider leiden tot meer vertrouwen bij de respondent?

- Heeft de respondent enige invloed (inspraak) kunnen uitoefenen op zijn/haar begeleiding, en zo ja, hoe?

- Welke rol spelen volgens respondenten de rechtvaardigheidsfactoren bij het waarnemen van de kansen van respondenten?

- Vindt de respondent het systeem van begeleiding op basis van zijn/haar persoonlijke ervaring rechtvaardig en eerlijk?

\section{Vertrouwen in begeleiding}

Vertrouwen zien de respondenten als het resultaat van een goede communicatie tussen twee partijen.

Respondent 1 ziet het vertrouwen als het resultaat van een interactie die gebaseerd is op begrip, eerlijkheid en openheid: 'Vertrouwen is niet eenzijdig, beide partijen moeten weten wat voor verwachtingen en mogelijkheden de andere partij heeft. Ze moeten eerlijk zijn. Openheid vind ik ook zeer belangrijk. Ik heb altijd vertrouwen in mijn begeleider gehad die mij heeft geholpen bij het vinden van een baan. Ik heb trouwens ook geluk gehad omdat ik heel snel een baan kon vinden.'

Respondent 2 zegt: 'De begeleider moet eerst vertrouwen hebben in zichzelf en goed weten wat hij zijn cliënt kan bieden. Dit moet altijd in overleg met zijn cliënt gebeuren.'

Respondent 5 brengt het ontstaan van vertrouwen in verband met het karakter en de persoonlijke eigenschappen van de begeleider: 'Ik heb op de internationale school een mentor gehad over wie ik heel ontevreden was. Ze dacht te weten wat goed voor mij was. Ze had weinig vertrouwen in mij. Ik kreeg door haar het gevoel dat ik weinig kon bereiken. Later op de middelbare school kreeg ik een andere mentor. Hij ondersteunde me en gaf me hoop. Omdat hij vertrouwen in mij had, kreeg ik het gevoel dat ik veel kon bereiken. Hij had echt een goed effect op mijn leven.'

Voor asielzoekers blijkt de kwestie vertrouwen anders te liggen.

Asielzoekers benoemen de informele begeleiding als de enige bron van begeleiding waarin ze vertrouwen hebben.

Respondent 12 heeft weinig vertrouwen in het COA en de formele begeleidingsinstantie: 'Welk vertrouwen? Hoe kan ik vertrouwen hebben in het systeem, terwijl we iedere dag bang zijn voor de inval van de vreemdelingenpolitie. Ik vertrouw de MOA ook niet. 
Doet er niet toe wat voor klachten je hebt, je krijgt altijd het advies om paracetamol in te nemen. Mijn kind heeft heel lang longontsteking gehad en de dokter heeft gezegd dat haar lichaam dit zelf moet herstellen. Ik kan ook op deze manier iedereen advies geven. In het azc denk je alleen maar aan overleven. Ik heb geen vertrouwen in het systeem.'

Respondent 19 heeft wel vertrouwen in haar Nederlandse kennissen. Ze hebben haar overal mee geholpen. Ze is daar erg dankbaar voor: 'Ik heb alle vertrouwen in hen, maar als je het over het COA hebt, weet ik het niet. Ik woon sinds een paar maanden in een COAhuis. Het is niet te vergelijken met het leven in een azc. Hier hebben we een klein beetje privacy. Je bent volgens mij je eigen begeleider, je moet actief zijn en je inzetten voor je doel. Maar dat moet je overal doen, toch?'

\section{Conclusie:}

Vertrouwen zien respondenten als een wederzijds verschijnsel. In twee domeinen (dat van respondent en dat van begeleider) zijn soortgelijke processen gaande: een parallelproces.

Volgens respondenten dient de begeleider in samenspraak met de respondent te constateren wat voor de respondent het beste is. De begeleider slaat daardoor een brug, zodat er een vertrouwensrelatie en een accepterende houding ontstaan en de respondent daardoor een 'holding' ervaart.

Vertrouwen is in dit perspectief niet te onderscheiden van inspraak en rechtvaardigheid. Asielzoekers kijken anders tegen de kwestie vertrouwen aan. De dreiging om uitgezet te worden en de onzekerheid over de toekomst in Nederland hebben een zichtbaar effect op de wijze waarop asielzoekers tegen de kwestie vertrouwen aankijken. Men leeft in een onbetrouwbare situatie. Er is sprake van onthechting.

\section{Inspraak en het waarnemen van kansen}

Respondenten zien een verband tussen inspraak en copingstijl. Degenen die zich assertief opstellen en voor hun belangen opkomen, maken meer kans in de Nederlandse samenleving. 'Als je in dit land een plek wilt verwerven, moet je ook niet voor een afwachtende houding kiezen en moet je het touwtje in eigen hand nemen.'

Respondent 3 legt een link tussen inspraak en persoonlijke houding: 'Ik heb zelf veel invloed gehad op mijn leven in Nederland. Dat heeft te maken met mijn eigen houding. Ik wacht niet af wat anderen voor me goed vinden. Dat is mijn levensovertuiging en als je in een vreemd land bent moet je alles opnieuw opbouwen, weet je ook dat je niet bij de pakken neer moet zitten. Ik gaf mijn begeleiders aan wat ik wilde en wat mijn doel was. Ik was ook niet bang om ondanks mijn matige taal een discussie te voeren. Inspraak moet je zeker hebben, anders moet je de rest van je leven ontevreden doorbrengen.'

Voor respondent 2 ligt de kwestie anders. 'Men luisterde niet naar me. Ik heb 15 jaar in Iran gewerkt als boekhouder. Ik gaf duidelijk aan wat ik wilde. Men vond mijn taal niet goed genoeg. Daarom moest ik eerst de opleiding administratie afmaken. Terwijl iedereen 
weet, dat voor boekhouding weinig taal nodig is. Na 8 jaar ging mijn nieuwe begeleider in op mijn vraag, en nu hoeft het voor mij allemaal niet meer. Ik heb er helemaal geen zin meer in.'

Respondent 8 had in Iran geen opleiding genoten en wilde in Nederland aan de bak komen. Ze is van mening dat ze soms wel inspraak heeft gehad: 'Het was wisselend. De ene keer had ik meer inspraak dan de andere keer. Ik heb een opleiding gevolgd om te kunnen werken. Die heb ik samen met mijn begeleider uitgezocht. Ik heb het met veel moeite afgerond en mijn best gedaan. Ik ben wel trots op mijzelf. Naarmate je de taal beter spreekt en meer begrijpt van de mogelijkheden in Nederland, kun je ook meer inspraak hebben.'

Respondent 18 is uitgeprocedeerd. Ze ziet assertiviteit als een doorslaggevende factor voor inspraak:'Dat is zeer moeilijk om inspraak te hebben, als je iedere dag denkt dat je uitgezet wordt. Toch dacht ik, dat ik ook zelf moest bepalen wat ik wil en hoe ik wilde leven. In Iran was ik leraar. In Nederland is er een andere cultuur. Men heeft in Iran veel waardering en respect voor zijn leraar. In Nederland is hiervoor minder respect. Bovendien moet je de taal goed spreken om les te kunnen geven. Anders zou men je pesten. Ik wil ook graag met mensen werken. Uiteindelijk heb ik gekozen voor de studie maatschappelijk werk. Het is mijn levensmotto om voor mijn eigen mening op te komen en actief invloed te hebben op mijn eigen lot. Het is zeer moeilijk om uitgeprocedeerd te zijn en invloed te hebben. Je moet ook niet veel verwachten. Ik moet bekennen dat sinds ik in een ROA-huis woon, ik me beter voel, meer privacy heb en ook meer rust. In het azc had ik het gevoel dat ik helemaal geen invloed had op mijn leven. Ook mijn studie heeft me het gevoel gegeven dat ik voor een deel kan bepalen wat ik wil.'

Respondent 15 is ook uitgeprocedeerd. Ze heeft andere ervaringen met inspraak: 'lk heb het gevoel dat ik geen invloed op mijn leven heb. In het azc moet je het ook niet verwachten. Wat de begeleiding betreft, die hebben we niet. Je lot ligt in de handen van de IND zolang je in het azc woont.'

\section{Conclusie:}

Inspraak heeft te maken met persoonlijke eigenschappen en hoe men in zijn/haar leven staat. Volgens de respondenten hebben assertieve mensen ook meer vertrouwen en ze zouden ook meer in staat zijn om invloed uit te oefenen op hun lot. Daarnaast achten de respondenten de rol van de begeleider als een zeer belangrijke factor. De ene begeleider is flexibeler dan de andere, heeft een open houding en hij/zij accepteert gemakkelijker de inspraak van de cliënt.

Externe factoren zijn daarnaast bepalend voor de mate van inspraak. Asielzoekers zien hun onduidelijke en onzekere positie in Nederland als een belangrijke externe factor waardoor zij geen inspraak en invloed kunnen uitoefenen op hun eigen lot. Het gevoel van machteloosheid overheerst. Zolang men geen verblijfsvergunning heeft, kan men ook geen inspraak hebben. 


\section{Rechtvaardigheid en het waarnemen van kansen in Nederland}

Het begrip rechtvaardigheid gaat vluchtelingen aan het hart. Respondenten hechten veel waarde aan het aspect rechtvaardigheid van hun begeleiding. Een goede begeleiding en een begeleiding die op maat gesneden is en rekening houdt met (on)mogelijkheden van cliënten. Een begeleiding die goed informeert en eerlijk verdeelt, is volgens respondenten rechtvaardig.

Respondent 3 heeft de volgende beschrijving over een goede begeleiding: 'Ik denk aan een begeleiding die mensen goed informeert over de bestaande mogelijkheden. Een eerlijke begeleider probeert niet voor zichzelf het werk te creëren, maar voor de vluchteling te werken. Het evenwicht tussen rechten en plichten. Dat betekent voor mij rechtvaardigheid.'

Respondent 5 beschrijft een rechtvaardige begeleiding als: 'Een rechtvaardige begeleiding sluit zich aan bij de mogelijkheden van de persoon zelf. Lang niet iedereen doet het even goed en is even sterk. Ook wat de taal betreft: de ene heeft een taalknobbel en de ander niet. Ik denk dat er ook verschil bestaat tussen begeleiders: ik had op school twee begeleiders. De ene was bekend als een aardig, betrokken iemand die zijn best deed voor de leerlingen. De andere was bekend als een gemeen en negatief iemand die leerlingen belemmerde in hun ontwikkeling door haar negatieve houding. Ik heb geluk gehad maar veel van de anderen niet. Er was regelmatig ontevredenheid en ook ruzie met die slechte begeleider. Je moet ook een beetje geluk hebben en de juiste persoon treffen.'

Respondent 10 geeft de volgende definitie over een rechtvaardige begeleiding: 'Voor mij betekent dit: iedereen op weg helpen en rekening houden met zwakke en sterke kanten van mensen. Een goede begeleider volgt niet klakkeloos de wet en de regeltjes. Een regel op papier betekent niet dat die ook in de praktijk toepasbaar is. Een rechtvaardige begeleiding is niet star maar flexibel. Een rechtvaardige begeleiding heeft oog voor gebreken en kan tegelijkertijd die begeleiding goed motiveren. Ach, misschien stellen we allemaal hoge eisen aan elkaar.'

Respondent 15 zegt: 'Een rechtvaardige begeleider is eerlijk en verschaft passende en goede informaties over de mogelijkheden die bestaan. Hij moet niet racistisch zijn en genoeg kennis hebben van de culturele aspecten van de cliënt maar: een dergelijke ideale begeleider bestaat niet.'

\section{Conclusie:}

Het is opvallend dat in de definities en beschrijvingen die de respondenten van rechtvaardigheid geven, de vijf regels van Leventhal (1980) zijn terug te vinden (consistentieregel, corrigeerbaarheidsregel, representativiteitsregel, accuraatheidsregel en ethiekregel (zie pagina 27). Daarnaast vinden de respondenten in hun begeleiding zowel de distributieve (verdelende) als de procedurele rechtvaardigheid belangrijk. 


\subsubsection{Conclusie cluster 3}

Ondanks het feit dat iedere respondent zijn/haar eigen definitie geeft van een goede begeleiding, is er een gemeenschappelijke lijn te schetsen in hun beschrijvingen. Zo komen in hun definities regelmatig vertrouwen, inspraak en rechtvaardigheid aan de orde. Het bestaan van de drie begeleidingsfactoren zien de respondenten als de basisvoorwaarden voor iedere goede en effectieve begeleiding. Deze aspecten komen spontaan voor bij informele begeleiding. Respondenten leggen een link tussen de begeleidingsfactor en de communicatieve en individueel gerelateerde betekenissen/functies van begeleiding.

\subsubsection{Cluster 4: De rol van de psychologische factoren}

De volgende vragen maken deel uit van deze cluster:

- Welke copingstijl denkt u dat u het meest hanteert?

- Welke copingstijl acht $u$ als het meest functioneel?

- Ziet u enig verband tussen de copingstijl en een succesvol integratieproces?

- Bent u/was u depressief in uw leven en zo ja, in welke periode?

- Heeft volgens u depressie enig effect op uw integratieproces?

\section{Copingstijl en waargenomen kansen}

Respondenten hebben een flexibel en realistisch beeld van het begrip copingstijl. Het begrip is meer impliciet van aard. Volgens respondenten is het wenselijk om een oplossingsgerichte coping te hanteren, maar dat is in de praktijk niet altijd mogelijk en ook niet verstandig. Je dient geen starre actieve coping te hebben, dus moet je desnoods ook afwachten en het tijd geven.

Respondent 4 zegt: 'lk denk dat beide stijlen nodig zijn. Het hangt van de situatie af. Soms moet je ook helemaal niets doen en moet je afwachten. Maar dat moet ook niet lang duren anders raak je in een depressie. Ik denk dat ik een combinatie van twee stijlen heb. Dat werkt goed.'

Respondent 7 ziet een oplossingsgerichte coping als effectief: 'Wat de begeleiding betreft, denk ik dat een actieve coping beter werkt. Laat zien wat je wilt en wat je in huis hebt. Maar wees alert dat je niet té assertief overkomt, anders voelt je begeleider zich overbodig. Hij moet ook zijn werk kunnen houden. Het is maar een speeltje hoor.'

Respondent 8 ziet actieve, resultaatgerichte coping als de beste stijl, maar dit is niet altijd mogelijk:'Ik heb zelf geen geduld en wil graag alles heel snel geregeld hebben, maar in Nederland en voor een lange periode was ik depressief en daardoor nam ik een passieve houding aan. Later heb ik de draad weer opgepakt. Ik heb nu het gevoel dat ik zelf invloed heb op mijn lot en mijn leven. Je kunt ook niet altijd alles op een actieve manier oplossen.'

Respondent 7 verwijt zichzelf dat ze zich over het algemeen passief opstelt: 'Ik denk dat ik zeer meegaand ben, misschien te meegaand. Door wachten, niet durven en bang zijn om een beslissing te nemen heb ik veel verloren. Nu geef ik aan wat ik wil. Ook ben ik meer assertief geworden en zeg tegen mijn begeleider wat ik graag wil. Maar ze heeft een ander beeld van mij. Dat beeld kan ik niet gemakkelijk wijzigen.' 
Respondent 17 ziet zijn actieve coping als de beste manier om te overleven in een nieuw land en vooral in het azc: 'Als iemand een beslissing neemt om te vluchten betekent dat, dat hij ook een actieve coping heeft. Anders zet je zo'n grote stap niet. Maar hier word je vooral geconfronteerd met je onmacht. De situatie makt van jou een ander mens. Je hebt geen effect op je eigen leven, daarom zijn mensen hier voor een groot deel passief, maar ook depressief. We helpen elkaar om ons erdoorheen te slepen.'

Respondent 15 vertelt: 'Je moet proberen een beetje actief te blijven, anders blijft van jou niets over. We krijgen geen begeleiding hier, daarom moeten we alles zelf regelen. Onze omgeving maakt ons depressief. Je moet geen grote plannen maken of hoge verwachtingen hebben, maar je moet je ook niet helemaal isoleren van de wereld.'

\section{Psychopathologie, depressie, trauma en kansperceptie}

Bijna iedereen heeft ervaring gehad met depressie. Respondenten benoemen depressie als een van de belangrijkste redenen waardoor ze minder kansen maken in de Nederlandse samenleving. Voor de meeste asielzoekers is depressie een soort reactie op hun moeilijke situatie in Nederland. Langdurige asielprocedure, onzekerheid over de toekomst in Nederland, passiviteit en weinig mogen doen, taalproblemen en vooral de dreiging om uitgezet te worden, benoemen asielzoekers als de belangrijkste oorzaak voor hun depressiviteit. Voor een groot deel hebben ze in Iran een actief leven geleid. Ze staan machteloos tegenover hun uitzichtloze situatie.

Respondenten delen hun trauma's in drie fasen in:

- Voor de vlucht.

- Tijdens de vlucht.

- Verblijf in Nederland.

De mate, de ernst en de reactie op de trauma's in deze drie fasen zijn verschillend. Trauma's die ze in Iran hebben meegemaakt, waren zowel lichamelijk als psychisch. De oorlog tussen Iran en Irak, arrestatie en marteling en gevangenschap in Iran, bedreiging, executie van dierbaren, benoemen respondenten als voorbeelden van hun trauma's in Iran. Tijdens de vlucht hebben ze ook te maken gehad met bedreigingen en onzekerheid. Men vreesde voor zijn eigen leven en veiligheid. Ook was er sprake van financiële risico's: er was geen garantie dat de smokkelaars hen niet zouden verraden en/of niet zouden oplichten. Respondenten geven aan dat ondanks de ernst van hun trauma's in de eerste twee fasen, zij min of meer en tot op zekere hoogte invloed konden uitoefenen op hun (toekomstige) situatie.

Volgens de respondenten krijgt trauma na de vlucht en in Nederland een andere aard en is dat van een andere orde. Passiviteit en machteloosheid zijn de kenmerken van de trauma's in de derde fase. Men kan helemaal geen invloed uitoefenen op zijn lot en situatie. Gebrek aan privacy, geen autonomie hebben, een afhankelijke positie, onduidelijkheid over het eigen leven en langdurige onzekerheid leiden tot diverse psychische klachten.

Respondent 2 zegt: 'Ik kreeg voor de eerste keer in Nederland tijdens mijn asielproce- 
dure echt te maken met een depressie. Het was zo zwaar dat ik pillen moest slikken. Ik had geen controle over mijn leven. Nog steeds voel ik me niet echt goed. Veel lichamelijke klachten waarvoor men geen reden kon vinden. Na de periode van het azc wilde ik graag actief meedoen aan de maatschappij en met veel enthousiasme zei ik dat ik de opleiding boekhouding wilde volgen. Ik had nota bene 15 jaar ervaring in Iran. Dat mocht toen niet van mijn begeleidster. Twee jaar heb ik mijn tijd moeten verspillen en nu heb ik helemaal nergens zin in. Door de slechte manier van begeleiding zie ik nu weinig kansen in Nederland. Ik ben nu bijna 49 jaar oud dus te oud voor de arbeidsmarkt. Ik voel me vaak somber. Ik heb in Iran geen trauma meegemaakt. Conflicten met het islamitische regiem en de oorlog met Irak, maar echte machteloosheid heb ik hier meegemaakt.'

Respondent 3 heeft bijna hetzelfde verhaal: 'Ik werd depressief in het azc. Ik had het gevoel dat ik geen autonomie had. De hele dag deed je niks. Drie keer eten en dan wachten op de volgende dag om nog een keer te gaan eten. Voor mij als politiek vluchteling betekende dit alles dat ik geen waarde had. De laatste periode in Iran ben ik ondergedoken. Dit was zeer moeilijk, iedere dag wist je dat dit de laatste dag van je leven zou kunnen zijn, een heel ander leven, maar actief en uitdagend. De reis naar Nederland was ook gevaarlijk. Mijn jongste zoon was met mij, het was voor hem als klein jochie een zeer angstaanjagende situatie. We hebben het gered en toen we onze voeten op de grond van Nederland zetten, had ik het gevoel, dat we nu veilig waren. Dit was een onbeschrijfelijk gevoel.

Wat ik wil zeggen is dat je je actieve leven dat je altijd hebt gehad in je vaderland onder druk moet zetten, je energie, hoop en enthousiasme moet je onderdrukken. Daarnaast ziet men je als leugenaar. Ik heb veel trauma's in Nederland in het azc meegemaakt. In het azc werd ik erg depressief, slikte ik pillen en ben ik daardoor ontzettend aangekomen. Mijn zelfbeeld en zelfwaardering worden echt aangetast. $\mathrm{Nu}$, na al die jaren, ben ik een succesvolle, zelfstandige vrouw die veel heeft bereikt, maar die wonden zijn nog niet genezen. Psychische begeleiding heb ik in die periode niet gehad. Bovendien kon ik niemand vertrouwen en dacht ik dat iedereen een spion van de Iraanse autoriteiten was. Ik was toen ook erg argwanend.'

Respondent 7 heeft een andere ervaring: 'Ik ken depressie niet en ik voel me somber. In Iran was ik niet depressief. Ik ben geen politieke vluchteling, ik was op zoek naar meer vrijheid. Net als veel anderen. Van nature ben ik een gemakkelijk type, ben geen intelligente en intellectuele persoon. In Nederland heb ik heel gauw een relatie gekregen met een Nederlandse vrouw. Ze heeft me overal mee geholpen en gesteund en ik kon bij haar intrekken. Vergeleken met veel andere vluchtelingen heb ik niet veel problemen gehad. Ik heb geen trauma meegemaakt, geen depressie en geen begeleiding. Een goed evenwicht tussen vraag en aanbod.'

Respondent 16 voelt zich depressief: 'Ik voel me echt depressief. Heb weinig contact met mijn eigen familie in Iran. Ik trek me hier ook terug in mijn eigen kamer en heb weinig zin om iets te doen. Je kunt ook weinig hier in het azc. Ik merk dat ik alles wat nuchter 
moet bekijken. Ik ben nu depressief. Ik wil geen pillen slikken. Misschien moet ik meer psychologische hulp zoeken bij de RIAGG. Mijn depressie heeft te maken met mijn situatie zowel hier als mijn trauma's in Iran: mishandeling door mijn man en eigen familie. De onzekerheid in Nederland maakt het leven zeer moeilijk. Ik denk dat ik getraumatiseerd ben.'

\subsubsection{Conclusie cluster 4}

Volgens respondenten werkt een flexibele coping het meest effectief. Op het sociaal-communicatieve niveau hecht men veel waarde aan oplossingsgerichte coping. Een actieve coping leidt tot een betere beeldvorming bij de begeleider. Een actieve oplossingsgerichte coping is een bewijsstuk voor je begeleider: je laat zien dat je het kunt en dat je je best doet.

Ook op operationeel niveau vinden respondenten het belangrijk om een actieve houding in te nemen.

De interactie tussen coping als een interne en individueel gebonden factor en de begeleiding als een externe factor is vooral bepalend voor de soort coping die respondenten hanteren. Respondenten geven aan dat een effectieve coping context gebonden is.

Uit de aangeleerde hulpeloosheidstheorie (Garber \& Seligman, 1980) blijkt dat men een gevoel van machteloosheid ervaart als men het gevoel krijgt dat men niet in staat is invloed uit te oefenen op de eigen situatie. Aangeleerde hulpeloosheid treedt op als de persoon denkt oplosbare problemen niet op eigen kracht op te kunnen lossen. De gevolgen van hulpeloosheid zijn divers. Men neemt een passieve houding aan en onderneemt weinig. Lage zelfwaardering en hoge machteloosheid vormen in deze situatie een grondslag voor depressiviteit.

Asielzoekers benadrukken dat ze geen enkele invloed kunnen uitoefenen op hun huidige situatie. Ze zien geen uitweg en hebben geen andere keuze. Dit gevoel van machteloosheid en geen invloed hebben zou tot depressiviteit kunnen leiden.

Depressie is een bekend verschijnsel voor bijna alle respondenten. Zowel asielzoekers als (ex-)vluchtelingen zijn van mening dat langdurige asielprocedure, onzekerheid en 'niks mogen doen', machteloosheid, gebrek aan autonomie en een afhankelijk en geïsoleerd leven in het azc de grondslag vormen voor depressiviteit. Depressie heeft verder een duidelijk effect op het waarnemen van kansen in Nederland. Respondenten leggen een link tussen de soort copingstijl en depressie enerzijds en het waarnemen van de kansen anderzijds. Tevens beschouwen de respondenten een begeleiding die niet goed aansluit bij de wensen, achtergrond en interesse van vluchtelingen als een belangrijke factor die depressie in de hand werkt.

Niet alle respondenten hebben te maken gehad met ernstige trauma's in hun leven. Degenen die wel ervaring hiermee hebben gehad, zien een duidelijk verschil tussen de drie eerdergenoemde verschillende fasen.

Zowel asielzoekers als (ex-)vluchtelingen ervaren de langdurige asielprocedure en het leven in onzekerheid als een (potentieel) trauma. 


\subsubsection{Cluster 5: De rol van discriminatie en cultuurverschil}

De volgende vragen maken deel uit van deze cluster:

- Wat is uw ervaring met discriminatie?

- Hebt u tijdens uw begeleiding te maken gehad met discriminatie?

- Heeft volgens u discriminatie enig effect op het waarnemen van uw kansen in Nederland?

- Ziet u verschillen tussen Iran en Nederland met betrekking tot de begeleiding, en zo ja, welke?

Over het algemeen zijn (ex-)vluchtelingen van mening dat de begeleiders niet direct discrimineren. Discriminatie heeft vooral een impliciet karakter. Respondenten zijn daarnaast van mening dat in de afgelopen jaren veel veranderd is in Nederland, en vooral op het sociaal-communicatieve niveau constateren ze veranderingen in de samenleving. De veranderingen hebben een negatief effect gehad op het waarnemen van kansen.

Respondent 1 constateert wel zichtbare veranderingen in de afgelopen periodes: 'Ik heb zelf niet direct met discriminatie te maken gehad, maar ik merk dat in de afgelopen jaren veel in Nederland veranderd is. Buitenlanders worden heel gauw in een hokje gezet. Vooral na de provocatie van Pim Fortuyn merk ik duidelijk een ander klimaat in Nederland. Daarnaast een rechtse, conservatieve regering die aan de macht is. Dat heeft voor mijn gevoel veel effect gehad op onderlinge verhoudingen tussen mensen in Nederland. Ik hoop maar dat dit tijdelijk is, anders zouden buitenlanders zich van Nederland en de Nederlanders vervreemden.'

Respondent 4 heeft te maken gehad met discriminatie:'Ik heb op basis van mijn uiterlijk een bepaald gevoel. Ik ben namelijk anders dan blanke Nederlanders. Ik voel me gevoelsmatig meer thuis als ik op vakantie in Spanje of Frankrijk ben. Daar heb ik het gevoel dat ik meer op die mensen lijk. Soms doen mensen uitspraken die misschien ook goed bedoeld zijn, maar inhoudelijk wel het gevoel van "niet erbij horen" of "anders zijn" kunnen geven, bijvoorbeeld je spreekt goed Nederlands hoor, net als een echte Nederlander, bijna zonder accent. Ben je hier geboren? Het is wel goed bedoeld, maar het heeft een ander effect. Verder denk ik zelf dat iedereen discrimineert. Het is wel belangrijk dat daardoor bepaalde groepen zich niet oneerlijk en onrechtmatig behandeld gaan voelen.'

Respondent 8 heeft het gevoel dat ze gediscrimineerd wordt: 'Op basis van mijn taal wel. Ik denk dat onze kinderen gemakkelijker geaccepteerd zijn dan wij. Omdat ik de taal niet goed spreek, kan ik me ook niet goed uitdrukken. Ik heb het gevoel dat ik mijn gevoelens en meningen niet goed kan bespreken. Soms denk ik dat de anderen mij stom vinden omdat ik de taal niet goed spreek, dan voel ik dat ze op een negatieve manier naar me kijken. Ik had het gevoel dat men mij niet serieus neemt vanwege mijn taalbeheersing. Voor mijn gevoel heeft discriminatie voor een groot deel te maken met het taalprobleem, maar ook anders eruitzien.'

Respondent 11 vertelt emotioneel: 'Ik heb wel degelijk met discriminatie te maken gehad. Als ik in een supermarkt boodschappen doe, heb ik het gevoel dat men me regel- 
matig in de gaten houdt. Ik ben er misschien te gevoelig voor omdat ik een asielzoeker ben.'

Respondent 13 voelt zich gediscrimineerd door het COA: 'In het contact met mijn Nederlandse kennissen niet, maar door de COA-medewerkers heb ik het gevoel wel. Ik heb het gevoel dat ze ons niet als gelijkwaardige mensen beschouwen, maar schapen die bij elkaar ergens leven. Ik krijg een slecht gevoel van hun kille, afstandelijke arrogante manier. Ik merk dat ik nu ook zeer boos ben op die lui. Ik heb er dus regelmatig mee te maken gehad. Gelukkig discrimineren niet alle Nederlanders. Ik heb lieve Nederlandse kennissen die veel begrip hebben voor mijn situatie. De Nederlandse regering neem ik het wel wegens hun beleid erg kwalijk.'

Respondent 16 geeft het huidige beleid de schuld: 'ledereen discrimineert wel eens, maar volgens mij is het de regering, die de meerderheid de richting aangeeft en het beleid bepaalt. Het systeem hier sluit bewust bepaalde groepen uit. Zwakke groepen worden natuurlijk de dupe van dit beleid. Vooral asielzoekers krijgen harde klappen. Dat geldt ook voor onze Afghaanse vluchtelingen in Iran. Die arrogantie van het islamitische regiem en vooral onderscheid maken tussen soennieten en sjiieten in Iran. Bewust hebben ze onderscheid tussen mensen gemaakt. Het systeem geeft de meerderheid eigenlijk een vrijbrief om te discrimineren.'

Respondent 18 zegt:'Ik heb wel te maken gehad met discriminatie: door de vreemdelingenpolitie en ook in het azc voelde ik me gediscrimineerd. Een keertje zei een medewerkster van het COA tegen mij: als je het in je eigen land beter kunt krijgen, moet je teruggaan naar je eigen land. Dit soort opmerkingen hoor je regelmatig en vaak met een vriendelijke toon. Alsof we allemaal uit vrije keuze hier zijn. Ik had tegen die mevrouw moeten zeggen: ja mevrouw, misschien is het beter voor jou dat ik in Nederland ben, anders heb je ook geen baan. Hoe kortzichtig sommige mensen kunnen zijn? Ook in de winkels en zo komt het voor dat ik me anders voel. Het gevoel dat ik niet echt erbij hoor zit vanbinnen.'

\section{Cultuurverschil en begeleiding}

Respondenten zien duidelijk een verschil tussen het systeem van begeleiding in de twee landen. Wat in Nederland als begeleiding vooral op het terrein van de arbeidsmarkt en de scholing bestaat, kennen respondenten in Iran niet.

Respondent 9 zegt: 'We hebben in Iran geen systematische begeleiding. Begeleiding krijg je van je ouders en natuurlijk ook op school, maar verder gerichte begeleiding hebben we niet. Familie geeft indirect veel begeleiding.'

Respondent 10 geeft ook dezelfde mening:'In Iran krijgen we adviezen van onze familie en kennissen. Ook op school zijn je leraren veel betrokken bij je leven. Wat werkbegeleiding betreft, hebben we zoiets als in Nederland niet. Het zit anders in elkaar dan in Nederland. Ik denk dat dit met individualisme te maken heeft. In Iran is het effect van je ouders op je leven echt groter dan in Nederland.'

Respondent 13: 'In Iran is de begeleiding echt slechter dan hier. Ik bedoel dat je alles zelf moet uitzoeken, vooral je ouders hebben veel invloed op je keuzes en je leven. Of dat 
goed of slecht is, weet ik niet. Over het algemeen hechten Iraniërs veel waarde aan opleiding en universitaire studie.'

Respondent 20: 'In je eigen land heb je geen begeleiding nodig. Je leert hoe alles werkt en je bent je eigen begeleider. Je ouders en je vrienden geven je ook advies en raad. Soms ervoer ik dit ook een beetje als bemoeizucht.'

\subsubsection{Conclusie cluster 5}

Respondenten hebben over het algemeen ervaringen gehad met discriminatie. Impliciete discriminatie beschouwen respondenten als een indirecte, maar veelvoorkomende discriminatie. Discriminatie beïnvloedt het waarnemen van de kansen in negatieve zin.

Tevens leggen sommige respondenten een link tussen de veranderingen in de politieke koers in Nederland en hun persoonlijke beleving van discriminatie. Respondenten geven aan dat door het veranderen van het politieke klimaat in Nederland ook de interpersoonlijke contacten veranderd zijn. Uit verhalen van asielzoekers blijkt dat ze zich vooral gediscrimineerd voelen door het COA.

Volgens respondenten heeft discriminatie een bijzondere affectieve lading.

Het is een subjectief gevoel, waardoor mensen zich kunnen vervreemden van de meerderheid. Opvallend is dat sommige respondenten discriminatie als een normaal verschijnsel zien. Toch keuren ze dit verschijnsel af en beschouwen het als onrechtvaardig.

Er bestaat een duidelijk verschil tussen de twee landen wat de wijze en het systeem van begeleiding betreft. In Iran is begeleiding voor een groot deel informeel en indirect en wordt vooral gegeven door ouders, familie, kennissen en vriendenkring. In Nederland bestaat er een formele begeleiding, die door de instanties gegeven wordt.

De begeleiding in Iran beschrijven de respondenten als impliciet en/of indirect. In Nederland heeft de begeleiding een direct en een doelgericht karakter en is daardoor meer expliciet.

\subsubsection{Samenvatting}

De belangrijkste uitkomsten van de diepte-interviews kan ik als volgt samenvatten:

- Respondenten zien integratie als een proces. Begeleiding heeft een doorslaggevend effect op het integratieproces.

- Diverse betekenissen die respondenten aan het begrip integratie geven, kunnen in vier categorieën verdeeld worden: sociaal-communicatief, normatief, individueel en instrumenteel.

- Respondenten hechten veel waarde aan informele begeleiding. Dit heeft vooral te maken met aspecten als betrokkenheid, gelijkwaardigheid, geen eigenbelang en het persoonlijke karakter van informele begeleiding.

- De vijf regels van Leventhal (1980) van een rechtvaardige procedure beschouwen respondenten als doorslaggevende factoren voor een succesvolle begeleiding.

- Het weet hebben van de cultuur en de achtergrond van respondenten zien respondenten als een belangrijke voorwaarde voor een goede begeleiding. 
- Een gelijkwaardige positie, een persoonlijke manier van begeleiding, respect en begrip voor de achtergrond en de bagage die de vluchteling meedraagt, vinden respondenten belangrijk voor een goede communicatie met hun begeleiders.

- Respondenten hebben voorkeur voor begeleiding die vooral hun krachten accentueert en niet de klachten en zwakke kanten.

- Respondenten hebben over het algemeen individuele ervaring met discriminatie.

\subsection{Onderzoek 3: data-analyse}

\subsubsection{Overzicht van variabelen en correlaties}

Een overzicht van de waarden van de variabelen die in de toetsing van de hypothesen en de beantwoording van de onderzoeksvragen aan de orde zullen komen, staat in bijlage 3 , tabel 1. Deze waarden zijn bij de toetsing van de variabelen gebruikt. Achtereenvolgens worden vermeld: de variabele, het gemiddelde en/of de mediaan, de standaarddeviatie en het aantal respondenten waarop deze waarden zijn gebaseerd. De correlatietabellen en de t-toets-resultaten staan vermeld in bijlage 4.

De vraagstelling en de hypothesen van onderzoek 3 staan al vermeld in hoofdstuk 1.

De beschrijving van de toetsing van de hypothesen is gebeurd in dezelfde volgorde als waarmee de hypothesen in hoofdstuk 1 zijn weergegeven. De paragrafen zijn ook thematisch ingedeeld. De hypothesen bij het betreffende thema worden aan het begin van de paragraaf vermeld.

Hieronder volgen de hypothesen van onderzoek 3:

- De mate van psychopathologieklachten en PTSS-klachten van de respondenten is over het algemeen hoog.

- Respondenten die onder de pardonregeling vallen hebben meer last van diverse psychopathologie- en PTSS-klachten dan respondenten met een permanente verblijfsvergunning.

- Er bestaat een hoge correlatie tussen psychopathologieklachten, passieve en vermijdende copingstijlen en PTSS-klachten. Hoe meer vermijdende en passieve coping, hoe meer psychische klachten.

- Demografische aspecten en met name leeftijd en geslacht hebben effect op de ervaren last van PTSS-klachten en de mate van psychopathologie.

\subsubsection{Resultaten van de toetsing van hypothesen}

\subsubsection{Hypothese 1}

Hypothese 1: de mate van algemene psychopathologie- en PTSS-klachten van de respondenten is over het algemeen hoog. 
Allereerst is nagegaan of de respondenten in hoge mate last ervaren van algemene psychopathologie- en PTSS-klachten. We hebben dan meteen een antwoord op onze hoofdhypothese.

Uit tabel 10.12 blijkt dat de mate van psychopathologie van de respondenten over het algemeen hoog is. Dit geldt ook voor depressieve en angstklachten. Deze resultaten komen overeen met de resultaten van onderzoek 1 dat bijna vijf jaar geleden heeft plaatsgevonden. De conclusie is gerechtvaardigd dat Iraanse vluchtelingen over het algemeen veel psychische klachten rapporteren.

Wat de PTSS-klachten betreft, heb ik de scores van de respondenten vergeleken met de normen van de HTQ en PSS. Voor de HTQ heb ik de totale score voor het aantal PTSS-symptomen berekend door het totaal van de scores op de items te delen door het nummer van beantwoorde items (Mollica et al., 1996). Bij een score boven 2.5 krijgt een persoon de diagnose PTSS.

Voor de PSS zijn de Nederlandse normen van het onderzoek van Engelhard et al. (2007) gebruikt. Engelhard et al. (2007) rapporteren de volgende normen:

- Geen diagnose $=$ beneden 14

- $\quad$ Diagnose angst $=15-27$

- $\quad$ Diagnose PTSS = boven 27

In tabel 10.11 is een vergelijking gemaakt tussen de gemiddelden en de standaarddeviaties van de onderzoeksgroep en de onderzoeksgroep van Engelhard et al. (2007) en de SCL-90 van de normale populatie. Vanwege de vergelijkingen zijn hier de oorspronkelijke ruwe scores gebruikt.

Uit tabel 10.11 blijkt dat de respondenten vergeleken met de normale populatie significant hoger scoren op de PSS (Engelhard et al. 2007) en de SCL-90-schalen (Arrindell \& Ettema, 1986). Voor de vergelijkingen zijn ruwe scores gebruikt en ze zijn niet gecodeerd. Voor de HTQ zijn er geen gegevens voor de normale populatie beschikbaar. 
Tabel 10.11 Vergelijking van de gegevens: gemiddelde, standaarddeviatie t-toets en p-waarde van de onderzoeksgroep en de normale populatie

\begin{tabular}{|c|c|c|c|c|}
\hline & $\begin{array}{l}\text { Onderzoeksgroep } \\
N=119 \\
M \text { \& SD }\end{array}$ & $\begin{array}{l}\text { Normale Populatie } \\
\mathrm{N} \\
\text { M \& SD }\end{array}$ & $\mathrm{T}$ & $\begin{array}{l}\text { P } \\
\text { Cohens'd }\end{array}$ \\
\hline PSS & $18.86(13.15)$ & $\begin{array}{l}40 \\
2.5(3.7)\end{array}$ & $t(153)=7.75$ & $\begin{array}{l}\mathrm{p}<.001 \\
\mathrm{~d}=1.42\end{array}$ \\
\hline $\mathrm{SCL}$ totaal & $183.30(60.59)$ & $\begin{array}{l}1053 \\
114.96(29.69)\end{array}$ & $t(1172)=20.72$ & $\begin{array}{l}\mathrm{p}<.001 \\
\mathrm{~d}=2.00\end{array}$ \\
\hline $\begin{array}{l}\text { SCL } \\
\text { DEP }\end{array}$ & 36.32 (12.64) & $\begin{array}{l}1052 \\
20.58(6.67)\end{array}$ & $t(1171)=21.52$ & $\begin{array}{l}\mathrm{p}<.001 \\
\mathrm{~d}=2.08\end{array}$ \\
\hline $\begin{array}{l}\mathrm{SCL} \\
\mathrm{ANG}\end{array}$ & $20.32(8.71)$ & $\begin{array}{l}1052 \\
12.23(3.80)\end{array}$ & $t(1171)=18.41$ & $\begin{array}{l}\mathrm{p}<.001 \\
\mathrm{~d}=1.78\end{array}$ \\
\hline $\begin{array}{l}\mathrm{SCL} \\
\mathrm{AGO}\end{array}$ & $11.88(4.96)$ & $\begin{array}{l}1052 \\
7.62(1.66)\end{array}$ & $t(1171)=19.78$ & $\begin{array}{l}\mathrm{p}<.001 \\
\mathrm{~d}=1.91\end{array}$ \\
\hline $\begin{array}{l}\mathrm{SCL} \\
\mathrm{SOM}\end{array}$ & $24.40(10.83)$ & $\begin{array}{l}1051 \\
15.99(4.90)\end{array}$ & $t(1170)=15.04$ & $\begin{array}{l}\mathrm{p}<.001 \\
\mathrm{~d}=1.45\end{array}$ \\
\hline $\begin{array}{l}\text { SCL } \\
\text { INA }\end{array}$ & $20.76(7.46)$ & $\begin{array}{l}1051 \\
12.48(4.10)\end{array}$ & $t(1170)=18.80$ & $\begin{array}{l}\mathrm{p}<.001 \\
\mathrm{~d}=1.82\end{array}$ \\
\hline $\begin{array}{l}\mathrm{SCL} \\
\mathrm{SEN}\end{array}$ & $36.96(12.15)$ & $\begin{array}{l}1052 \\
23.66(7.25)\end{array}$ & $t(1171)=17.44$ & $\begin{array}{l}\mathrm{p}<.001 \\
\mathrm{~d}=1.69\end{array}$ \\
\hline $\begin{array}{l}\mathrm{SCL} \\
\mathrm{HOS}\end{array}$ & $10.97(4.29)$ & $\begin{array}{l}1052 \\
7.22(2.11)\end{array}$ & $t(1171)=16.02$ & $\begin{array}{l}\mathrm{p}<.001 \\
\mathrm{~d}=1.55\end{array}$ \\
\hline $\begin{array}{l}S C L \\
\text { SLA }\end{array}$ & $6.43(2.06)$ & $\begin{array}{l}1051 \\
4.24(2.04)\end{array}$ & $t(1170)=11.04$ & $\begin{array}{l}\mathrm{p}<.001 \\
\mathrm{~d}=1.07\end{array}$ \\
\hline
\end{tabular}


Tabel 10.12 De uitslagen van de 119 respondenten op de SCL-90-klachtenlijst

\begin{tabular}{|l|l|l|l|l|l|l|l|}
\hline SCL-90 & $\begin{array}{l}\text { Zeer } \\
\text { laag }\end{array}$ & Laag & Ben-gem & Gem & $\begin{array}{l}\text { Boven- } \\
\text { gem }\end{array}$ & Hoog & $\begin{array}{l}\text { Zeer } \\
\text { hoog }\end{array}$ \\
\hline ANG & $0.8 \%$ & $5 \%$ & $8.4 \%$ & $10.1 \%$ & $17.6 \%$ & $31.9 \%$ & $26.2 \%$ \\
\hline AGO & $0.8 \%$ & $16.8 \%$ & $4.2 \%$ & $3.4 \%$ & $14.3 \%$ & $27.7 \%$ & $32.8 \%$ \\
\hline DEP & $0.1 \%$ & $0.8 \%$ & $3.4 \%$ & $7.5 \%$ & $15.1 \%$ & $30.3 \%$ & $42.8 \%$ \\
\hline SOM & $4.1 \%$ & $14.8 \%$ & $8.6 \%$ & $8.2 \%$ & $8.4 \%$ & $28.6 \%$ & $27.3 \%$ \\
\hline INA & $0 \%$ & $4.1 \%$ & $10.7 \%$ & $7.5 \%$ & $9.8 \%$ & $33.6 \%$ & $34.3 \%$ \\
\hline SEN & $0.8 \%$ & $3.2 \%$ & $7.4 \%$ & $11.5 \%$ & $9 \%$ & $28.6 \%$ & $39.5 \%$ \\
\hline HOS & $0.2 \%$ & $3.5 \%$ & $2.8 \%$ & $4.1 \%$ & $23 \%$ & $33.6 \%$ & $32.8 \%$ \\
\hline SLA & $0 \%$ & $8.2 \%$ & $0.6 \%$ & $5.5 \%$ & $19.2 \%$ & $50.2 \%$ & $16.3 \%$ \\
\hline Totaal & $1.6 \%$ & $3.2 \%$ & $7.3 \%$ & $5.7 \%$ & $12.2 \%$ & $18 \%$ & $52 \%$ \\
\hline
\end{tabular}

ANG = angst $; A G O=$ agorafobie; $D E P=$ depressie; $S O M=$ somatisatieklachten; INA = inadequatie van gedachten; $S E N=$ sensitiviteit; $H O S=$ hostiliteit; $S L A=$ slaapproblemen; Totaal = neuroticisme

Hieronder staan ook de resultaten van de uitslagen van respondenten op de twee PTSSvragenlijsten (de HTQ en de PSS) uitgedrukt in normscores.

Tabel 10.13 PTSS-vragenlijsten: (HTQ, PSS)-uitslagen van de 119 respondenten in percentages

\begin{tabular}{|l|l|}
\hline Vragenlijst & Percentages \\
\hline HTQ & $77 \%$ \\
\hline$\leq 2.5$ & $23 \%$ \\
\hline$>2.5$ & \\
\hline PSS: & $32 \%$ \\
\hline $0-13$ & $39 \%$ \\
\hline $14-27$ & $29 \%$ \\
\hline$>27$ & \\
\hline
\end{tabular}


Bij de HTQ scoort 23\% van de respondenten gelijk of boven 2.5. Dit betekent dat de meerderheid van de respondenten (77\%) niet voldoet aan de diagnose PTSS volgens de Amerikaanse normen (Mollica et al., 1996). Voor HTQ zijn er geen normen bekend voor de normale Nederlandse populatie.

Uit de resultaten van de PSS bleek dat de scores van 32\% van de respondenten beneden 14 liggen (Normaal). De scores van 39\% liggen tussen 14-27 (als bij diagnose angst). $29 \%$ van de respondenten scoort boven 27 (voldoen aan diagnose PTSS).

Deze resultaten laten zien dat de meerderheid van de respondenten veel psychopathologische klachten rapporteert (tabellen 10.12 en 10.13). Respondenten scoren niet zo hoog op de PTSS-vragenlijsten dat ze in meerderheid in het criterium van de diagnose PTSS vallen.

Hypothese 1 wordt hiermee gedeeltelijk bevestigd.

\subsubsection{Hypothese 2}

Hypothese 2: respondenten die onder de pardonregeling vallen, hebben meer last van diverse psychopathologie- en PTSS-klachten dan respondenten met een permanente verblijfsvergunning.

Er zijn 55 respondenten die onder de pardonregeling vallen en 64 respondenten met een permanente verblijfsstatus. Voor de toetsing van hypothese 2 is een t-toets gebruikt. Uit de toetsing blijkt het volgende:

- Er bestaat een significant verschil tussen de twee groepen met betrekking tot de mate van ervaren angst: $\mathrm{t}(117)=2.86 ; \mathrm{p}=.005$. Respondenten met een pardonregeling $(M=5.80 ; S D=1.35)$ hebben meer angstklachten dan de statushouders $(M=5.03$; $\mathrm{SD}=1.54)$.

- Er bestaat een significant verschil tussen de twee groepen met betrekking tot de ervaren agorafobische klachten: $\mathrm{t}(117)=3.41 ; \mathrm{p}<0.01$. Respondenten met een pardonregeling $(M=5.87 ; S D=1.52)$ hebben meer klachten dan de statushouders $(M=4.77$; $\mathrm{SD}=1.94)$.

- Er bestaat een significant verschil tussen de twee groepen met betrekking tot de mate van somatisatieklachten: $\mathrm{t}(117)=2.65 ; \mathrm{p}=.009$. Respondenten met een pardonregeling $(M=5.53 ; S D=1.55)$ rapporteren meer klachten dan de statushouders $(M=4.59$; $\mathrm{SD}=2.18)$.

- Er bestaat een significant verschil tussen de twee groepen met betrekking tot depressieve klachten: $\mathrm{t}(117)=2.08 ; \mathrm{p}=.040$. Respondenten met een pardonregeling $(\mathrm{M}=$ $6.24 ; \mathrm{SD}=.98)$ rapporteren meer klachten dan de statushouders $(M=5.78 ; S D=1.25)$.

- Er bestaat een significant verschil tussen de twee groepen met betrekking tot de mate van sensitiviteit: $\mathrm{t}(117)=2.42 ; \mathrm{p}=.017$. Respondenten met een pardonregeling hebben meer klachten $(M=6.05 ; S D=1.17)$ dan de respondenten met een permanente verblijfsvergunningsstatus $(M=5.41 ; S D=1.65)$. 
- Er bestaat een significant verschil tussen de ervaren hostiliteit $t(117)=2.06 ; p=.041$. Respondenten met een pardonregeling $(M=6.09$; $S D=1.07)$ hebben meer klachten dan de statushouders $(M=5.66 ; S D=1.19)$.

- $\quad$ r is een significant verschil tussen de mate van algemene psychopathologie tussen de twee groepen: $\mathrm{t}(117)=2.02 ; \mathrm{p}=.045$. Respondenten met een pardonregeling hebben meer klachten $(M=6.13 ; S D=1.49)$ dan de statushouders $(M=5.55 ; S D=1.61)$.

- Er bestaat een significant verschil tussen de twee groepen met betrekking tot de HTQ-scores (totaal): $\mathrm{t}(117)=3.52 ; \mathrm{p}<0.01$. Respondenten met een pardonregeling $(\mathrm{M}=2.00 ; \mathrm{SD}=.49)$ rapporteren meer last dan de statushouders $(\mathrm{M}=1.62 ; \mathrm{SD}=.66)$.

- Er bestaat een significant verschil tussen de twee groepen met betrekking tot de PSS-scores: $\mathrm{t}(117)=2.94 ; \mathrm{p}=.04$. Respondenten met een pardonregeling $(\mathrm{M}=22.55$; $S D=10.09)$ hebben meer last dan de statushouders $(M=15.63 ; S D=14.65)$.

Hypothese 2 wordt bevestigd. Respondenten die onder de pardonregeling vallen, ervaren over het algemeen meer psychische klachten dan respondenten met een permanente verblijfsvergunning die al langer in Nederland wonen. Uit de resultaten blijkt dat respondenten met een pardonregeling ook meer PTSS-klachten rapporteren dan de respondenten met een permanente verblijfsvergunning. De resultaten van de t-toetsen staan vermeld in bijlage 4 tabel 1.

Verschillen tussen de twee groepen werden vervolgens exploratief getoetst (bijlage 4, tabel 1). Uit de resultaten blijkt het volgende:

- Er bestaat een significant verschil tussen de twee groepen met betrekking tot het toepassen van passieve coping: $\mathrm{t}(117)=2.75 ; \mathrm{p}=.007$. Ex-vluchtelingen passen minder passieve coping toe $(M=3.80 ; S D=.94)$ dan respondenten die onder de pardonregeling vallen $(M=4.24 ; S D=.76)$.

\subsubsection{Hypothese 3}

Hypothese 3: er bestaat een hoge correlatie tussen psychopathologieklachten, passieve en vermijdende copingstijlen en PTSS-klachten. Hoe meer vermijdende en passieve coping, hoe meer psychische klachten.

Allereerst geef ik hieronder een overzicht van de resultaten van de zeven schalen van de UCL. 
Tabel 10.14 Utrechtse Copingvragenlijst (UCL): uitslagen van de 119 respondenten

\begin{tabular}{|l|l|l|l|l|l|}
\hline Copingstijl & Zeer laag & Laag & Gemiddeld & Hoog & Zeer hoog \\
\hline AC & $6.7 \%$ & $16.8 \%$ & $53 \%$ & $18.5 \%$ & $5 \%$ \\
\hline PAL & $0.8 \%$ & $5 \%$ & $60.5 \%$ & $20.2 \%$ & $13.5 \%$ \\
\hline VER & $3.4 \%$ & $4.2 \%$ & $62.2 \%$ & $18.5 \%$ & $11.7 \%$ \\
\hline SOC & $2.7 \%$ & $10 \%$ & $52.7 \%$ & $24.8 \%$ & $9.8 \%$ \\
\hline PAS & $0.8 \%$ & $2.5 \%$ & $26.9 \%$ & $35.3 \%$ & $34.5 \%$ \\
\hline EXP & $2.5 \%$ & $4.5 \%$ & $50 \%$ & $32.2 \%$ & $10.8 \%$ \\
\hline GER & $0.8 \%$ & $5.1 \%$ & $42.8 \%$ & $27.5 \%$ & $23.8 \%$ \\
\hline
\end{tabular}

$A C=$ actieve coping; $P A L=$ palliatieve coping; $V E R=$ vermijdingscoping; $S O C=$ sociaal contact zoeken; $P A S=$ passieve coping; $E X P=$ expressie van gevoel; $G E R=$ geruststellende gedachten

Er zijn correlaties berekend tussen de psychopathologieklachten, PTSS-klachten en de passieve en vermijdende copingstijlen. Er is een Pearson-correlatietoets gebruikt. De resultaten zijn vermeld in bijlage 4 .

Uit de analyses blijkt het volgende:

- $\quad$ r is een significante correlatie gevonden tussen passieve coping en algemene psychopathologieklachten van de respondenten $(r=0.63 ; \mathrm{N}=119 ; \mathrm{p}<0.01)$.

- Er bestaat een significante correlatie tussen passieve coping en de PSS-vragenlijst $(r=0.51 ; N=119 ; p<0.01)$.

- Er bestaat een significante correlatie tussen passieve coping en HTQ (totaal) $(r=0.42$; $\mathrm{N}=119 ; \mathrm{p}<0.01)$.

- Er bestaat een significante correlatie tussen passieve coping en PTSS-diagnose volgens de HTQ $(r=0.52 ; \mathrm{N}=119 ; \mathrm{p}<0.01)$.

- $\quad$ r is een negatieve correlatie tussen de actieve coping en de totale scores van de SCL$90(r=-.21 ; N=119 ; p=.018)$.

De hypothese wordt gedeeltelijke bevestigd. Passieve coping correleert significant met de PTSS-klachten en met algemene psychopathologieklachten. Vermijdende coping correleert niet significant met de klachten. De resultaten van de correlatietoetsingen staan vermeld in bijlage 4, tabellen 2 en 3. 


\subsubsection{Hypothese 4}

Hypothese 4: leeftijd en geslacht hebben effect op de ervaren last van PTSS-klachten, de mate van psychopathologie en gehanteerde copingstijlen.

Uit de toetsing blijkt het volgende (bijlage 4, tabel 3):

- $\quad$ r is geen significant verschil gevonden tussen mannen en vrouwen met betrekking tot de algemene psychopathologieklachten en/of PTSS-klachten.

- Er bestaat een significant verschil tussen mannen en vrouwen met betrekking tot de actieve coping: $\mathrm{t}(117)=3.60 ; \mathrm{p}<0.01$. Vrouwen $(\mathrm{M}=3.32 ; \mathrm{SD}=.71)$ hanteren vaker actieve coping dan mannen $(\mathrm{M}=2.74 ; \mathrm{SD}=.96)$.

- Er bestaat een significant verschil tussen de twee groepen met betrekking tot afleiding zoekende coping: $\mathrm{t}(117)=2.04 ; \mathrm{p}=.044$. Vrouwen zoeken vaker afleiding $(\mathrm{M}=$ 3.58; $\mathrm{SD}=.78)$ dan mannen $(\mathrm{M}=3.28 ; \mathrm{SD}=.82)$.

- Er bestaat een significant verschil tussen de twee groepen met betrekking tot het toepassen van vermijdende coping: $\mathrm{t}(117)=2.07 ; \mathrm{p}=.041$. Vrouwen $(\mathrm{M}=3.50 ; \mathrm{SD}=.81)$ passen vaker vermijdende coping toe dan mannen $(M=3.17 ; S D=.87)$.

- Het effect van leeftijd was voor de algemene psychopathologieklachten, copingstijlen en PTSS niet significant (zie bijlage 4, tabel 3).

\subsubsection{Samenvatting}

In onderzoek 3 zijn er twee traumavragenlijsten gebruikt. De aanleiding hiervoor waren de hoge psychopathologische klachten van de respondenten van onderzoek 1 waarbij de vraag rees in hoeverre deze samenhingen met PTSS.

De respondenten van onderzoek 1 verschillen van onderzoek 3 met betrekking tot hun verblijfsstatus. Respondenten van onderzoek 3 waren allemaal in het bezit van een verblijfsvergunning en ze wonen allemaal langer dan vijf jaar in Nederland. Ik heb wel een onderscheid gemaakt tussen de twee groepen binnen onderzoek 3. Het onderscheid heeft te maken met de soort verblijfsvergunning. De groep (ex-)vluchtelingen beschikt over een permanente verblijfsvergunning of heeft de Nederlandse nationaliteit, terwijl de groep pardonregeling een tijdelijke verblijfsvergunning heeft. De belangrijkste uitkomsten van onderzoek 3 kan ik als volgt samenvatten:

- Respondenten hebben veel psychopathologieklachten en met name depressieve, angst- en agorafobische klachten. Dit komt overeen met de resultaten van onderzoek 1.

- De groep pardonregeling rapporteert meer psychopathologieklachten dan de groep permanente statushouders.

- Respondenten met een pardonregeling rapporteren over het algemeen meer PTSS-klachten dan respondenten met een permanente verblijfsstatus.

- Respondenten hebben meer last van psychopathologie, angst, depressieve klachten en PTSS-klachten vergeleken met de normale Nederlandse populatie. 
- De meerderheid van de respondenten scoort niet hoog op de twee traumavragenlijsten en valt niet in de normen van een PTSS-diagnose. Dit betekent dat de hoofdhypothese verworpen kan worden.

- $\quad$ r is een positieve en significante correlatie gevonden tussen de passieve coping en de algemene psychopathologie en traumascores van de respondenten. De correlaties van vermijdingscoping met traumascores en met algemene psychopathologie waren niet significant, in tegenspraak met de hypothese.

- Er zijn verschillen gevonden tussen mannen en vrouwen met betrekking tot actieve, afleiding zoekende en vermijdende coping.

- Het niveau van PTSS-klachten is niet van dien aard dat de gerapporteerde psychopathologie vooral vanuit PTSS te verklaren is. 

Deel V

Discussie 


\section{Hoofdstuk 11}

\section{Discussie}

In dit hoofdstuk volgt na een korte inleiding eerst een discussie over de resultaten van de drie onderzoeken. Steeds wordt per thema aangegeven in hoeverre de resultaten een ondersteuning vormen voor de hypothesen en wat in het kort de antwoorden op de explorerende vragen hebben opgeleverd, waarna verklaringen worden gegeven voor de uitkomsten. Waar dit relevant is, wordt vergeleken met uitkomsten uit andere onderzoeken. Vervolgens passeren de theoretische en praktische implicaties de revue. Ten slotte komen beperkingen van de drie onderzoeken van deze studie aan bod alsmede implicaties voor vervolgonderzoek.

\section{$11.1 \quad$ Inleiding}

Voor deze verhandeling is gekozen om de sociaalpsychologische en gezondheidspsychologische invalshoek te nemen om de begeleiding van Iraanse (ex-)vluchtelingen en asielzoekers naar integratie in kaart te brengen. Dit doe ik ook vanuit het perspectief van de crossculturele psychologie.

Deze keuze is mede gemaakt omdat ik geïnteresseerd ben in de subjectieve en persoonlijke beleving van vluchtelingen in het algemeen en mijn landgenoten in het bijzonder, van de begeleiding die ze in Nederland hebben ontvangen om te kunnen integreren en zich thuis te voelen. Daarnaast is het voor mij belangrijk om op een wetenschappelijke en verantwoorde manier een beeld te geven van de knelpunten en de (on)mogelijkheden van de begeleiding. Verder wil ik mijn eigen waarneming uit de praktijk vergelijken met een wetenschappelijke toetsing.

Bij aanvang deed ik een sociaal- en gezondheidspsychologische literatuurstudie over de procedurele rechtvaardigheid en de psychopathologie onder migranten en vluchtelingen. Dit was niet mogelijk zonder een blik te werpen op de crossculturele psychologie. De thema's die daarin zijn gevonden, zijn toegespitst op de huidige studie.

Onderzoek 1 is een correlationeel en kwantitatief onderzoek. Het onderzoek had tot doel de relatie tussen de evaluatie van de begeleiding naar integratie en de kansperceptie van de respondenten op positieverbetering door begeleiding te expliciteren. Hoofdeffecten en modererende effecten van individuele en psychologische factoren werden nader onderzocht.

Onderzoek 2 is een kwalitatief onderzoek. De bedoeling was om de persoonlijke ervaringen over begeleiding door middel van diepte-interviews te expliciteren en deze te vergelijken met het eerste (kwantitatieve) onderzoek. 
Bij het verrichten van onderzoek 3 was mijn aandacht gericht op psychopathologie en vooral op posttraumatische klachten van de respondenten en de rol die de verblijfsvergunning daarin heeft. De hoge mate van diverse psychopathologische klachten van de respondenten in onderzoek 1 riep de vraag bij mij op in welke mate een verblijfsvergunning van invloed is op de psychopathologie en de PTSS-klachten van de respondenten. Bovendien rees naar aanleiding van onderzoek 1 en 2 de vraag in hoeverre de hoge mate van psychopathologie te begrijpen was als voortkomend uit PTSS.

\subsection{Resultaten}

De resultaten zijn in drie clusters te verdelen:

- De eerste cluster betreft de resultaten van de onderzoeken naar de sociaalpsychologische variabelen en het patroon daarvan: de begeleidingsfactoren (inspraak, vertrouwen, rechtvaardigheid) en de correlatie tussen de afhankelijke variabele 'kansperceptie' en deze begeleidingsfactoren. De eerste cluster is in de onderzoeken 1 en 2 geanalyseerd. Er zijn diverse vergelijkingen gemaakt tussen asielzoekers en (ex-)vluchtelingen met betrekking tot hun kansperceptie en de mate van tevredenheid over de begeleiding die ze ontvangen.

- De tweede cluster betreft de resultaten van de onderzoeken naar de modererende effecten van individuele en psychologische variabelen. In onderzoek 1 staat het modererende effect van de individuele variabelen (leeftijd, verblijfsstatus, geslacht) en psychologische variabelen (psychopathologieklachten, depressie en copingstijlen) centraal.

- De derde cluster betreft de algemene psychopathologie- en de PTSS-klachten. In onderzoek 3 heb ik getracht de vraag te beantwoorden in hoeverre respondenten last hebben van diverse psychopathologie- en PTSS-klachten. Ik heb de twee groepen pardonregeling en (ex-)vluchtelingen met elkaar vergeleken wat de mate en het patroon van psychopathologie-, PTSS-klachten en copingstijlen betreft. De centrale vraag betreft de kwestie of het vooral PTSS is dat de hoge mate van psychopathologie kan verklaren.

Ik bespreek hieronder de resultaten van de drie onderzoeken.

\subsubsection{Resultaten van onderzoek 1}

Onderzoek 1 is een correlationeel en kwantitatief onderzoek. Door middel van vier vragenlijsten is vooral aandacht besteed aan de (subjectieve) beleving van de respondenten van hun kansperceptie op positieverbetering in Nederland. Daarnaast heb ik getracht de vraag te beantwoorden of individuele en psychologische factoren een modererende rol spelen in de relatie tussen de kansperceptie van de respondenten en de drie begeleidingsfactoren (rechtvaardigheid, vertrouwen en inspraak). De steekproef bestond uit asielzoe- 
kers (zonder verblijfsstatus) en (ex-)vluchtelingen (met een permanente verblijfsstatus). De resultaten van de twee groepen zijn met elkaar vergeleken.

Hypothesen en samenvatting van de resultaten

Hieronder passeren de hypothesen en de samenvatting van de resultaten de revue. Vervolgens komen de verklaringen en interpretatie van de resultaten aan de orde.

Hypothese 1 gaat ervan uit dat respondenten hun kansen op positieverbetering vergroot achten door begeleiding. Deze hypothese is bevestigd (tabel 10.1). Uit de resultaten kan worden geconcludeerd dat zowel asielzoekers als (ex-)vluchtelingen van mening zijn dat hun kansen door begeleiding verbeterd zijn. De kansperceptie is het grootst bij het vinden van een baan, gevolgd door beroepsvaardigheden en algemene en geestelijke gezondheid. Zelfvertrouwen en cultuuroverbrugging scoren laag.

Hypothese 2 gaat vervolgens ervan uit dat respondenten die meer vertrouwen hebben in hun begeleiding, hun begeleiding als rechtvaardiger beoordelen, meer inspraak ervaren ten opzichte van hun begeleiding en een hogere inschatting laten zien van hun kansen op positieverbetering. Uit de analyses bleek dat de drie begeleidingsfactoren significant correleren met de kansperceptie van de respondenten (bijlage 2 tabel 1). Deze hypothese is bevestigd.

Hypothese 3 betreft de relatie tussen kansperceptie en het beschikken over een verblijfsvergunning. Hypothese 3 gaat ervan uit dat er een groot verschil bestaat tussen de twee groepen asielzoekers (zonder een verblijfsvergunning) en (ex-)vluchtelingen (met een verblijfsvergunning) wat hun kansperceptie betreft. De resultaten steunen deze hypothese. Asielzoekers zien duidelijk minder kansen dan (ex-)vluchtelingen en het verschil tussen de twee groepen is significant (bijlage 2, tabel 4).

Hypothese 4 gaat over de verschillen tussen de twee groepen in de mate van depressie en algemene psychopathologische klachten. Er is van uitgegaan dat asielzoekers meer last ervaren van diverse psychopathologische klachten dan (ex-)vluchtelingen. Uit de analyses bleek inderdaad dat asielzoekers meer depressieve en andere psychopathologische klachten rapporteren dan (ex-)vluchtelingen (bijlage 2, tabel 4).

Hypothese 5 veronderstelt dat asielzoekers geneigd zijn meer passieve en vermijdende copingstijlen toe te passen dan (ex-)vluchtelingen. Deze hypothese is gedeeltelijk bevestigd. Uit de analyses bleek dat het verschil tussen de twee groepen voor passieve coping significant is. Asielzoekers passen meer passieve coping toe dan (ex-)vluchtelingen. Dit verschil is voor de vermijdende coping niet significant. Daarnaast bleek dat (ex-)vluchtelingen meer en/of vaker dan asielzoekers actieve copingstijlen toepassen. Het verschil tussen de twee groepen is niet significant

De laatste hypothese van onderzoek 1 betreft de modererende effecten van individuele en psychologische variabelen op de relatie tussen tevredenheid over begeleiding en kansperceptie.

Op het effect van leeftijd na, is deze hypothese niet bevestigd. Uit regressieanalyses 
bleek dat deze factoren de richting van de relatie tussen tevredenheid en kansperceptie niet significant beïnvloeden. Verder bleek dat er bij jongere respondenten een groter effect van tevredenheid is over integratie op kansperceptie dan bij oudere respondenten. Voor alle anderen individuele (geslacht, verblijfsvergunning) en psychologische variabelen (depressie, diverse copingstijlen en algemene psychopathologie) zijn er geen modererende effecten gevonden.

\section{Interpretatie van de resultaten van onderzoek 1}

Bestaat er in de werkelijkheid wel zoiets als kansperceptie?

Respondenten blijken daarover een referentiekader te hebben. Deze indruk komt voort uit de resultaten van onderzoek 1 . Het blijkt dat beide groepen overtuigd zijn van de rol van begeleiding bij een succesvolle integratie (boven 70\%). Daarnaast waren de twee groepen het ermee eens dat de begeleidingsfactoren (rechtvaardigheid, vertrouwen en inspraak) een positief effect hebben op hun kansperceptie op positieverbetering. Er is een significante correlatie gevonden tussen de drie begeleidingsfactoren en de kansperceptie van de respondenten.

$\mathrm{Er}$ is geen groot meningsverschil gevonden tussen de twee groepen asielzoekers en (ex-)vluchtelingen over de rol van een goede begeleiding: zo acht $85 \%$ van alle respondenten de rol van de begeleiding belangrijk bij het vinden van een baan. $79 \%$ van de respondenten gelooft dat een goede begeleiding zijn/haar psychische en lichamelijke gezondheid zal bevorderen en $80 \%$ is van mening dat de begeleiding hem/haar zal helpen bij het bevorderen van de beroepsvaardigheden.

Uit de toetsing van hypothese 2 bleek dat de drie begeleidingsvariabelen hoog met de kansperceptie correleren. De correlatie tussen de variabele tevredenheid (samengesteld uit de drie begeleidingsvariabelen) en de afhankelijke variabele kansperceptie was hoog $(r=0.80 ; p<.01)$. Dit betekent dat er een sterke onderlinge relatie bestaat tussen de drie begeleidingsfactoren enerzijds en de kansperceptie van de respondenten anderzijds: respondenten die meer vertrouwen hebben in de begeleiding, ervaren meer inspraak in hun begeleiding en ze ervaren hun begeleiding als rechtvaardig. Ze hebben daarnaast een optimistischer beeld van een succesvolle integratie. Hypothese 2 is hiermee bevestigd. Dit resultaat komt overeen met de bevindingen van Ramaekers (2003) over het verband tussen kansperceptie en de drie begeleidingsfactoren.

Hoewel asielzoekers en (ex-)vluchtelingen een hoge waarde hechten aan de begeleiding en ze van mening zijn dat hun kansen door de begeleiding bevorderd worden, bleek uit de toetsing van hypothese 3 dat de asielzoekers beduidend minder positief zijn over hun positieverbetering door de begeleiding dan respondenten met een verblijfsstatus. Uit de vergelijkingen tussen de twee groepen komt verder naar voren dat asielzoekers minder kansen waarnemen dan de (ex-)vluchtelingen. Het verschil tussen de twee groepen is significant. Deze bevindingen en de replicatie van resultaten van eerdere studies ondersteunen de validiteit van de kansperceptiemetingen. 
Uit de toetsing van hypothese 4 bleek dat beide groepen veel last ervaren van diverse psychopathologische klachten. Het bleek dat de mate van algemene psychopathologie, depressie en angst over de hele linie hoog is. Dit neemt niet weg dat asielzoekers meer psychische klachten rapporteren dan (ex-)vluchtelingen. Tussen mannen en vrouwen heb ik geen significant verschil gevonden.

De mogelijke verklaring voor de naar voren gekomen verschillen tussen de twee groepen kan volgens mij gevonden worden in de positie van asielzoekers. De onzekere situatie waarin ze leven, postmigratiefactoren, het leven met machteloosheid en onzekerheid over hun toekomst in een vreemd land zouden ertoe kunnen leiden dat asielzoekers meer psychologische klachten rapporteren en minder positief zijn over hun kansperceptie. Uit de literatuurstudie blijkt inderdaad dat migranten en vluchtelingen over het algemeen, en asielzoekers in het bijzonder in vergelijking met de normale bevolking meer last ervaren van psychopathologische klachten (zie hoofdstuk 6 en 8). Daarnaast blijkt dat de postmigratiefactoren, onder andere acculturatiefactoren, van invloed zijn op ervaren (on)welbevinden van vluchtelingen (zie hoofdstuk 6).

Gerritsen et al. (2007) en Laban et al. (2008) komen op basis van hun onderzoeken eveneens tot de conclusie dat asielzoekers over het algemeen veel psychische en lichamelijke klachten rapporteren en negatiever denken over hun levensperspectieven.

Bij de Iraanse respondenten is er sprake van een hoge mate van algemene psychopathologie. Vanuit de stresstheorie en steunend op de migratiestudies kan worden geconcludeerd dat blootstelling aan stressvolle situaties, ervaren verlies en life events tot een kwetsbaarheid voor diverse psychische klachten kunnen leiden.

Een belangrijke uitkomst van onderzoek 1 is het verschil tussen de twee groepen met betrekking tot de passieve en vermijdende copingstijlen. Uit de toetsing van hypothese 4 bleek dat asielzoekers vooral geneigd zijn meer passieve coping te hanteren. Dit is volgens de verwachting. Asielzoekers zitten jarenlang in asielzoekerscentra. Daar is weinig te doen. Men is afhankelijk van de begeleiders van het COA. Autonomie en zelfstandigheid worden niet gemotiveerd, integendeel, deze worden juist tegengehouden. Het is niet verwonderlijk dat mensen zich erg kwetsbaar gaan voelen, erg onzeker zijn over zichzelf en hun toekomst, en het gevoel hebben dat ze weinig invloed kunnen uitoefenen op hun lot en leven in het nieuwe land. Het feit dat (ex-)vluchtelingen gunstiger scoren op diverse factoren, en met name lager scoren op de passiviteitschaal, was volgens de verwachtingen. Dit heeft te maken met hun positie in Nederland. Ze wonen al langer in Nederland, zijn zeker over hun verblijfsvergunning, ervaren meer autonomie, zijn zelfstandiger geworden en hebben meer tijd gehad om zich aan te kunnen passen aan de normen en de verwachtingen van de Nederlandse samenleving. Ze hebben betere taalvaardigheden, ze mogen werken, en ten slotte hebben ze een groter netwerk en meer sociale contacten. Deze factoren leiden er (waarschijnlijk) toe dat asielzoekers in vergelijking met (ex-)vluchtelingen meer geneigd zijn om vaker passieve copingstijlen toe te passen dan (ex-)vluchtelingen. De laatste hypothese van onderzoek 1 gaat over het modererende effect van zowel de individuele variabelen (demografische kenmerken en het bezit van een verblijfsvergun- 
ning) als de psychologische variabelen (depressie, psychopathologie, copingstijlen). De resultaten van onderzoek 1 laten zien dat actieve-gedragsmatige coping een hoofdeffect heeft op de kansperceptie. Als alleen gecontroleerd wordt voor geslacht en leeftijd, dan heeft verblijfsvergunning een hoofdeffect. Door het meenemen van de actieve-gedragsmatige coping vervalt het hoofdeffect van verblijfsvergunning.

De rol van psychopathologie als een moderator is onderzocht. Uit de regressieanalyses bleek dat psychopathologie geen modererend effect heeft op de kansperceptie (tabel 10.8). Voor diverse copingstijlen, geslacht en verblijfsvergunning zijn er ook geen modererende effecten gevonden. Dit was niet volgens de verwachting. Dit betekent dat hypothese 6 in grote lijnen kan worden verworpen. Leeftijd is de enige moderator die de relatie tussen tevredenheid over de begeleiding en kansperceptie sterk beïnvloedt. Jongere respondenten die weinig tevreden zijn over hun begeleiding hebben een lagere kansperceptie dan oudere respondenten die weinig tevreden zijn.

Als mogelijke verklaring voor het modererende effect van leeftijd kan men bijvoorbeeld denken aan een grotere gevoeligheid van jongere respondenten voor begeleiding waar ze ontevreden over zijn, terwijl oudere respondenten autonomer zijn en zich minder afhankelijk voelen van hun begeleiding.

Voor de hoge psychopathologische klachten van de respondenten kan ik de volgende mogelijke verklaringen opperen.

Mijn eerste verklaring zou zijn dat zowel de meegemaakte trauma's in het land van herkomst als de postmigratiefactoren- en de acculturatiefactoren in Nederland voor een soort kwetsbaarheid zorgen waardoor psychopathologie eerder tot stand komt.

De tweede verklaring zou te maken kunnen hebben met'affectieve en communicatieve componenten' van begeleiding. Deze componenten worden voor een groot deel gemist na migratie, wat tot diverse psychopathologieklachten zou kunnen leiden.

Een mogelijke verklaring wat betreft het verschil tussen asielzoekers en (ex-)vluchtelingen met betrekking tot hun kansperceptie zou te maken kunnen hebben met de positie van asielzoekers en het feit dat voor deze groep integratie minder vorm heeft gekregen. Asielzoekers zijn nog niet in dezelfde mate en/of op dezelfde wijze in aanraking gekomen met de formele begeleiding gericht op integratie als (ex-)vluchtelingen.

\subsubsection{Resultaten van onderzoek 2}

\section{Samenvatting van de resultaten}

Onderzoek 2 was een kwalitatief onderzoek. Het onderzoek kwam tot stand door middel van diepte-interviews. Zowel asielzoekers als (ex-)vluchtelingen zijn geïnterviewd. Er is een topiclijst samengesteld met 5 clusters. De vragen per cluster werden door een diepte-interview geëxpliciteerd.

De uitkomsten van onderzoek 2 hebben diverse aspecten van individuele beleving van de geïnterviewden van hun kansperceptie in beeld gebracht. Ik heb daarnaast aandacht besteed aan culturele aspecten, acculturatiestrategieën en de persoonlijke ervaring van 
respondenten met thema's als discriminatie. Uit de interviews bleek dat respondenten veel waardering hebben voor de begeleidingsvariabelen (vertrouwen, rechtvaardigheid en inspraak). Ze waren het ermee eens dat begeleiding een cruciale rol speelt bij het integratieproces. De uitkomsten van de interviews lieten daarnaast een pessimistisch en negatief beeld zien van de formele begeleiding. Aan de respondenten zijn vragen gesteld over hun individuele en persoonlijke beleving van begeleiding naar integratie. Het bleek dat respondenten zich over het algemeen niet begrepen voelden door hun begeleiders. Men voelde zich in vele gevallen in de steek gelaten en soms gediscrimineerd. Sommige respondenten beschreven formele begeleiding als afstandelijk, zakelijk en soms weinig betrokken.

Respondenten hadden weinig vertrouwen in de formele begeleiding. Ze ervoeren weinig inspraak in de genomen beslissingen en ze zagen het proces van begeleiding naar integratie als 'niet rechtvaardig'. Dit in tegenstelling tot de informele begeleiding, die persoonlijk is, dicht bij de persoon staat, betrokken is, vertrouwen opwekt en sensitief en responsief is. Verder zien de respondenten de persoonlijkheid van begeleiders als een belangrijke factor voor een goede begeleiding. Dit betekent dat de ene begeleider meer betrokken en geïnteresseerd is dan de andere begeleider.

Het contact houden met de Nederlandse vrienden en kennissen en de gewone Nederlandse bevolking werd zeer op prijs gesteld en gewaardeerd.

De antwoorden op de explorerende vragen duiden verder aan dat respondenten zichzelf en hun prestaties, persoonlijke successen en/of falen in Iran met die in Nederland vergelijken. Ze gaven verklaringen over de oorzaken van hun successen die ze in hun land hebben bereikt en die ze hopen in Nederland te bereiken. De kansperceptie van de respondenten betreft diverse gebieden: arbeidsmarkt, scholing en onderwijs, communicatie met autochtonen en hun financiële situatie.

\section{Interpretaties en de verklaringen}

De verklaringen die respondenten gaven over hun kansperceptie op positieverbetering, zijn voor een deel volgens de verwachtingen. Respondenten schreven hun successen toe aan eigen inzet en de steun die ze hebben kunnen krijgen van informele begeleiding. Ze schreven hun falen vooral toe aan de formele begeleiding.

Volgens de attributietheorie zouden successen of falen verklaard kunnen worden door uit te gaan van interne (persoonlijke) of externe (situationele) oorzaken. Bij interne attributie wordt de causaliteit toegewezen aan interne factoren of eigen kracht, en deze vallen binnen de eigen controle van de persoon. Bij externe attributie wordt de causaliteit toegewezen aan een factor van buitenaf. Externe factoren bevinden zich buiten de controle van de persoon. We zijn geneigd om de successen van anderen en de mislukkingen van onszelf aan externe factoren toe te schrijven. Uit de interviews blijkt dat deze neiging duidelijk aanwezig is.

Een mogelijke verklaring voor deze negatieve en/of kritische houding ten opzichte van 'formele begeleiding' en de negatieve opmerkingen over 'formele begeleiding' zou kun- 
nen zijn dat de begeleiding niet goed aansluit bij het persoonlijke verwachtingspatroon, de waarden, normen en/of culturele achtergrond van de respondenten.

Weer een andere verklaring voor deze discrepantie kan mogelijk gevonden worden in de verschillen die (vermoedelijk) bestaan tussen de cognitieve, communicatieve en affectieve waarden die respondenten hechten aan de begeleiding. In cognitief opzicht hechten respondenten een hoge waarde aan begeleiding omdat begeleiding geacht wordt hun positie te verbeteren. Vanuit communicatief opzicht ligt de kwestie anders. De twee verschillende talen en culturele achtergronden, acculturatieaspecten, zakelijkheid en afstandelijkheid van de begeleider, strakke regels en beperkingen zorgen er bijvoorbeeld voor dat de begeleiding minder gewaardeerd wordt. Vanuit affectief opzicht herhaalt het verhaal zich opnieuw. In onderzoek 2 vertellen respondenten dat ze distantie voelen in de wijze waarop hun begeleiders met hen contact maken. Met andere woorden: de werkrelatie is vooral zakelijk en minder affectief.

De hechtingstheorie zou ook voor een deel een verklaring voor de kritiek kunnen geven. Bowlby (1969), Ainsworth \& Bowlby (1954) en Stern (1977) hebben het hechtingsgedrag van baby's en peuters in interactie met hun opvoeders en verzorgers bestudeerd. Hun navolgers hebben hechtingsgedrag onderzocht bij volwassenen (Rholes \&Simpson, 2004; Stein et al., 2002). Een mens heeft als ieder zoogdier de neiging om zich vanaf zijn geboorte te hechten aan de regelmatig aanwezige figuren in hun leven. In de kindertijd gaat het vooral om verzorgers. Hoe betrouwbaarder, (emotioneel) beschikbaarder en veiliger deze figuren zijn, hoe veiliger de hechting. Een veilige hechtingsfiguur is sensitief en responsief. Deze aspecten blijven belangrijk en onmisbaar voor de latere relationele contacten voor volwassenen. Hechting kan door onveiligheid in de omgeving, door traumata (ook bij de verzorgers), verstoord raken; men raakt ambivalent of angstig gehecht. De hechtingstheorie stelt dat bij mensen die een gezonde hechtingsstijl hebben, dit 'opnieuw hechten' in nieuwe situaties gemakkelijker gaat. Dit zou bij mensen met angstige hechtingsstijlen veel moeizamer tot stand komen. Indien de oorspronkelijke vertrouwensfiguren in het land van herkomst juist ook degenen zijn geweest die de onveiligheid mede veroorzaakten, dan is er ook sprake van een 'attachment injury' die het moeilijker maakt onbekenden in vertrouwen te nemen. In dit geval kunnen we verwachten dat mensen gevoeliger zijn ten opzichte van hun begeleider als een betrouwbaar figuur. Dit stelt dus extra eisen aan de vertrouwensrelatie die begeleiders aangaan. Daarnaast heeft een (on)veilig hechtingsgedrag invloed op de wijze waarop mensen sociale steun geven en/of vragen (Bowlby, 1969; Johnson \& Whiffen, 2005; Mikulincer \& Shaver 2007; Mikulincer \& Shaver 2009). Mensen die veilig gehecht zijn, zijn ook beter in staat om sociale steun te geven en te ontvangen.

Op zoek naar iets herkenbaars, iets eigens, ontmoeten vluchtelingen nieuwe mensen in het nieuwe land. Ze hopen dan zich te kunnen hechten aan deze (hopelijk betrouwbare) figuren. Wat de respondenten van deze studie missen, is waarschijnlijk een sensitieve en responsieve manier van begeleiden die aan deze behoefte tegemoetkomt. Dit zou niet alleen leiden tot grotere tevredenheid, maar ook tot een positievere kansperceptie op positieverbetering. 


\subsubsection{Resultaten van onderzoek 3}

Onderzoek 3 is een correlationeel en kwantitatief onderzoek. De steekproef bestond voor een deel uit respondenten die ook meegedaan hadden aan onderzoek 1 . Het verschil met onderzoek 1 is dat alle respondenten in het bezit waren van een verblijfsstatus. Er was wel een verschil tussen de twee groepen binnen de onderzoeksgroep. Respondenten die onder de pardonregeling vallen, hadden een voorlopige en tijdelijke verblijfsstatus.

In onderzoek 3 is vooral aandacht besteed aan psychopathologische klachten en de posttraumatische stressstoornis. De uitkomst van onderzoek 1 was de belangrijkste reden voor het verrichten van onderzoek 3. De aanleiding was vooral de hoge mate van ervaren psychopathologische klachten van de respondenten van onderzoek 1, en de vraag in hoeverre dit aan PTSS toe te schrijven zou kunnen zijn. In onderzoek 1 werden PTSS en PTSS-klachten niet gemeten.

\section{Hypothesen en samenvatting van resultaten}

Hypothese 1 gaat ervan uit dat de mate van algemene psychopathologie en PTSS-klachten over het algemeen hoog is.

Deze hypothese is voor een groot deel bevestigd. Er bleek inderdaad dat respondenten veel last ervaren van zowel depressie als angstklachten. Ze scoorden daarnaast hoog op algemene psychopathologieklachten. In vergelijking met de normale Nederlandse populatie scoorden respondenten van onderzoek 3 hoger op diverse specifieke psychopathologieklachten (zie tabel 10.11).

Verder bleek dat de meerderheid van de respondenten wel hoger, maar niet significant hoog scoort op de PTSS-vragenlijsten dat ze binnen de normen van de diagnose PTSS vallen. De hoofdhypothese van onderzoek 3 werd dus verworpen. Het is belangrijk om te benadrukken dat de ernst van de PTSS-klachten van de respondenten op de HTQ is vergeleken met een Amerikaanse patiëntenpopulatie en niet met een Nederlandse normale populatie. Op de andere schaal van PTSS-klachten, de PSS, kon dit echter wel gebeuren.

Hypothese 2 maakt een onderscheid tussen de groep pardonregeling (met een tijdelijke verblijfsvergunning) en (ex-)vluchtelingen (met een permanente verblijfsvergunning). De veronderstelling van hypothese 2 was dat respondenten met een tijdelijke verblijfsvergunning vergeleken met respondenten met een permanente status meer psychopathologische klachten, inclusief PTSS-klachten, ervaren.

Deze hypothese werd bevestigd. De resultaten lieten zien dat respondenten met een tijdelijke verblijfsstatus op bijna alle psychopathologieschalen hoger scoren, en de verschillen zijn over het algemeen significant.

Hypothese 3 veronderstelt de samenhang tussen psychopathologie en passieve en vermijdende copingstijlen.

Uit de resultaten van de toetsingen bleek inderdaad dat respondenten die vooral geneigd zijn om passieve copingstijlen toe te passen, ook meer psychopathologische klachten op de SCL-90 en PTSS-klachten rapporteerden. Voor vermijdende coping heb ik geen significante correlaties gevonden. 
Hypothese 4 gaat ervan uit dat zowel geslacht als leeftijd effect hebben op de mate van psychopathologie, PTSS-klachten en copingstijlen.

Deze hypothese is in grote lijnen verworpen. De enige uitzondering betreft het verschil tussen mannen en vrouwen met betrekking tot actieve, afleiding zoekende en vermijdende coping. Vrouwen passen meer actieve coping toe dan mannen en het verschil tussen de twee groepen was significant. Verder bleek dat vrouwen vaker op zoek zijn naar een afleiding dan mannen. Tegelijkertijd passen mannen in moeilijke situaties minder vermijdende coping toe dan vrouwen.

\section{Interpretatie en verklaringen}

Hoe kunnen we deze resultaten verklaren?

Bij mijn eerste verklaring ga ik ervan uit dat de respondenten veel life events hebben meegemaakt die tot veel angst- en depressieve klachten hebben geleid. Deze ervaringen hoeven niet per se een trauma volgens de DSM-IV te zijn.

Wat betreft de gevonden verschillen tussen de groep pardonregeling en de groep (ex-) vluchtelingen, kan het volgende opgemerkt worden. Uit de resultaten bleek dat de groep pardonregeling meer psychische klachten heeft dan de groep (ex-)vluchtelingen die een permanente verblijfsvergunning heeft. Een verklaring voor de hogere mate van klachten van de groep pardonregeling zou kunnen zijn dat de meerderheid van hen nog steeds in asielzoekerscentra woonachtig was en/of niet zeker was over hun permanente verblijf (toen onderzoek 3 plaatsvond). Deze respondenten waren nog niet begonnen met taallessen en ze waren praktisch gezien nog niet in staat om een zelfstandig en autonoom bestaan op te bouwen. Dit betekent dat de factor onzekerheid in hun dagelijks leven nog krachtig aanwezig was. Diverse stressfactoren, zoals de stress van het vluchten, de asielprocedure, en het wonen in een asielzoekerscentrum, waren nog steeds aanwezig en voelbaar in hun leven. Andere belangrijke stressfactoren zijn bijvoorbeeld het niet kunnen werken, en de confrontatie met de eisen en de verwachtingen van de samenleving om zelfstandig en autonoom te kunnen functioneren ( $x 2(4, N=148)^{\prime} s>64$, p's < .001). De leden van de pardonregelingsgroep voelden zich wellicht nog angstig en onzeker omdat men bang is niet te kunnen voldoen aan de verwachtingen.

Uit de toetsingen kan geconcludeerd worden dat respondenten met een pardonregeling meer passieve coping toepassen dan (ex-)vluchtelingen. Er zijn positieve relaties gevonden tussen vermijdende en passieve coping en psychopathologie- en PTSS-klachten. In de literatuurstudie zijn er diverse studies verricht naar het verband tussen PTSS en de copingstijlen. In deze studies zijn vooral correlaties gevonden tussen de vermijdende coping, depressie en PTSS-klachten (zie resultaten). Deze resultaten zijn volgens de verwachtingen. Uit de literatuur blijkt verder dat copingstijl 'context afhankelijk' is. Dit betekent dat wanneer er een probleem als controleerbaar gezien en ervaren wordt, mensen ook meer probleemoplossende en actieve copingstijlen hanteren dan wanneer ze weinig controle kunnen uitoefenen op de situaties (Folkman \& Lazarus, 1980; Carver et al., 1989). Uit onderzoek 1 en 3 bleek dat psychopathologie en depressie hoog met passieve coping 
correleren. Dit zou kunnen betekenen dat respondenten met een passieve coping meer risico lopen om psychische klachten te ontwikkelen.

Dit neemt het niet weg dat het net zo goed mogelijk is dat zowel depressie als psychopathologie tot het toepassen van passieve copingstijl kan leiden. Uit diverse literatuurstudies weten we dat er duidelijke relaties bestaan tussen emotionele copingstijlen, en met name vermijdende copingstijl, en depressie, PTSS en psychopathologische klachten (Gil, 2005; Olff et al., 2005; Mosher \& Prelow, 2007; Yamada et al., 2003).

De uitkomsten van de twee kwantitatieve onderzoeken zijn voor een deel verklaarbaar in het kader van de stresscopingtheorie van Folkman \& Lazarus. In situaties waarin men zich machteloos voelt en/of weinig controle ervaart (asielzoekers en personen met een tijdelijke verblijfsvergunning), is men geneigd om meer emotiegerichte coping te hanteren. Emotionele coping is dan realistischer en functioneler dan oplossingsgerichte copingstrategieën.

\subsection{Implicaties van het onderzoek}

\subsubsection{Theoretische implicaties}

De procedurele rechtvaardigheidstheorie

In deze studie is aannemelijk gemaakt dat de twee groepen asielzoekers en (ex-)vluchtelingen dezelfde waarde hechten aan het belang van integratievariabelen (vertrouwen, rechtvaardigheid, inspraak). Dit betekent dat ze over het algemeen vanuit hetzelfde perspectief hun begeleiding naar integratie beoordelen. Dit impliceert dat de inzichten vanuit de procedurele rechtvaardigheidstheorie hier kunnen worden toegepast. Zowel (ex-) vluchtelingen als asielzoekers zijn sterk ervan overtuigd dat de drie begeleidingsfactoren, vertrouwen, inspraak en rechtvaardigheid, zeer bepalend zijn voor het begeleidingsproces naar integratie. Begeleiding die deze aspecten bevat, bevordert volgens de twee groepen hun kans op positieverbetering in Nederland.

Toch zijn er enkele kanttekeningen te plaatsen met betrekking tot het toepassen van deze theorie.

Het eerste aandachtspunt is volgens mij dat er een discrepantie bestaat tussen de theoretische beschrijvingen en de persoonlijke beleving van de respondenten in de praktijk. Wat men meent belangrijk te vinden voor een goede begeleiding, kan verschillen van wat men in de praktijk meent te hebben ervaren.

Het tweede aandachtspunt heeft te maken met de grote nadruk die de theorie legt op de cognitieve aspecten van de procedure waarmee de wijze van beleving vooral een cognitief accent krijgt. Uit deze studie blijkt dat de respondenten ook een grote nadruk leggen op de affectieve en communicatieve aspecten. Respondenten menen dat aspecten als vertrouwen, inspraak en rechtvaardigheid niet weg te denken zijn bij een goede begeleiding. Daarnaast, en misschien net zo belangrijk, is de hoge waarde die respondenten hechten aan de persoonlijke manier van het geven van begeleiding. Respondenten 
waarderen een begeleiding die warm is, niet afstandelijk en/of zakelijk, die meer aansluit bij de persoonlijke behoeften en (on)mogelijkheden van cliënten, en oog en interesse heeft voor de (culturele) achtergrond van cliënten. Kortom, een 'begeleiding die sensitief en responsief' is. In het kader van hun persoonlijke beleving hebben respondenten een grote waardering voor informele begeleiding die belangeloos is, die zich niet beperkt tot regels en wetten en die niet zakelijk is. In de theorie krijgen deze affectieve aspecten, zoals persoonlijke communicatie, empathie en warmte, betrokkenheid, sensitiviteit, responsiviteit en flexibiliteit minder aandacht dan de cognitieve aspecten.

Het tweede aandachtspunt heeft naar mijn mening te maken met de geringe aandacht die de theorie heeft voor de culturele aspecten. Zoals vele andere theorieën van de sociale psychologie, heeft deze theorie een westers cultureel fundament. De specifieke kenmerken van mensen met een niet-westerse culturele achtergrond, en met name van migranten en vluchtelingen uit niet-westerse gebieden, komen in deze theorie niet tot hun recht. Zakelijkheid en afstandelijkheid in de begeleiding worden in westerse culturen misschien als meer'vanzelfsprekend' ervaren dan in oosterse culturen. Dit verschil zou kunnen leiden tot een ander verwachtingspatroon en andere communicatiecodes bij vluchtelingen en hun begeleiders. In lijn hiermee toont onderzoek 2 aan dat respondenten aspecten als het beheersen van de Nederlandse taal, de wijze van betekenisgeving, en de non-verbale communicatiemiddelen zeer belangrijk vonden voor een goede communicatie met hun begeleiders.

Concluderend: met betrekking tot de procedurele rechtvaardigheidstheorie kan gesteld worden dat culturele achtergrond en daaraan gebonden affectieve factoren weinig aandacht krijgen in de theorie van procedurele rechtvaardigheid.

Het begrijpen van de hoge mate van psychopathologie bij asielzoekers en (ex-)vluchtelingen

Voor dit aspect van het onderzoek heb ik gekozen voor een geïntegreerd theoretisch kader. De cognitieve theorie en de stressbenadering vormen gezamenlijk het theoretische kader.

Uit de literatuurstudie (zie hoofdstuk 6 en 8) blijkt dat acculturatie en andere postmigratieproblemen als ernstige life events ervaren kunnen worden.

Vanuit experimentele, klinische en migrantenstudies is de conclusie gerechtvaardigd dat zowel de meegemaakte trauma's en verliezen als het leven onder langdurige stress tot het ontwikkelen van psychopathologische klachten zouden kunnen leiden. In de literatuur en in de Nederlandse GGZ bestaat de neiging om veel van de psychische problemen van asielzoekers en (ex-)vluchtelingen in verband te brengen met trauma's volgens de DSM-definitie en daarmee met PTSS. Respondenten van deze studie rapporteren echter geen overmatige PTSS-klachten, wel veel angst en depressie en andere algemene psychopathologie en veel life events.

In beide kwantitatieve onderzoeken is er aandacht besteed aan psychopathologie, waaronder de posttraumatische klachten van de respondenten. Op basis van de bevindingen van deze studie kan geconcludeerd worden dat vooral angst- en depressieve klachten 
het psychopathologische beeld van de respondenten domineren. Dit geldt voor zowel asielzoekers als voor respondenten met een tijdelijke verblijfsstatus en ook voor respondenten met een permanente verblijfsstatus en/of de Nederlandse nationaliteit. Voor de (ex-)vluchtelingen zouden deze postmigratiefactoren een risicofactor kunnen zijn voor het ontstaan van psychopathologie. Respondenten van de kwalitatieve studie (zie onderzoek 2) gaven aan dat de postmigratiefactoren en met name de wijze waarop ze begeleiding hebben gekregen, soms tot stress en het gevoel van machteloosheid hebben geleid.

Het is aan te bevelen de zorgwekkende uitkomst van deze studie vanuit een breed perspectief in acht te nemen. De bevindingen van deze studie suggereren dat deze klachten veel meer voortkomen uit de stress en de machteloosheid die de opvangcentra, de asielprocedure en de problematische integratie met zich meebrengen dan door specifieke trauma-ervaringen in het land van herkomst.

\subsubsection{Praktische implicaties}

De resultaten van de drie onderzoeken laten zien dat ondanks het bestaan van een soort 'homogeniteit' onder de respondenten er duidelijke verschillen bestaan tussen de subjectieve belevingen van de respondenten en de mate van kwetsbaarheid voor psychopathologieklachten.

Vlucht betekent in vele gevallen een ongewilde onthechting. Uit mijn studie blijkt dan ook dat asielzoekers en vluchtelingen een kwetsbare groep vormen voor het ontwikkelen van diverse psychische klachten. Dit vergt extra aandacht voor de levensomstandigheden van asielzoekers. Het gaat over langdurig leven in een onzekere situatie, waardoor de kwetsbaarheid voor psychopathologie in de hand wordt gewerkt.

Asielzoekers rapporteren op basis van de bevindingen van deze studie meer psychopathologische klachten dan (ex-)vluchtelingen. Een betere opvang van en begeleiding aan asielzoekers kan een positief effect hebben en leiden tot het verminderen van psychopathologische klachten. Daarnaast kan het toepassen van goede, sensitieve en individueel gerichte en op maat gesneden begeleiding in deze periode een buffer zijn tegen de ontwikkeling van diverse psychische klachten, ook in de latere levensfasen van de asielzoekers.

Alvorens verder in te gaan op de implicaties van dit onderzoek voor de praktijk, moet eerst worden opgemerkt dat er diverse ontwikkelingen spelen in de Nederlandse gezondheidszorg en arbeidsmarkt. De gevolgen hiervan voor de begeleiding zijn niet direct te voorspellen. Eén van deze ontwikkelingen is de pardonregeling voor en de begeleiding van bijna 26.000 mensen die in aanmerking zijn gekomen voor een verblijfsvergunning. Deze nieuwe ontwikkeling vergt speciale aandacht en zorg vanwege de diversiteit binnen deze groep en het ingewikkelde karakter van de opvang van asielzoekers.

Een andere ontwikkeling is dat er steeds meer stemmen opgaan om vluchtelingen 'zelf en zonder een gerichte begeleiding' veel zaken te laten regelen. Dit heeft te maken met de financiële overwegingen die de overheid maakt. Deze overwegingen zouden volgens mij kunnen leiden tot een risico. Het risico dat er veel ad hoc gewerkt zal worden en dat de daar- 
mee samenhangende stress tot nog meer psychopathologie zal leiden dan nu al het geval is.

Op basis van de bevindingen van dit onderzoek weten we hoe belangrijk het voor vluchtelingen is om als gelijkwaardige partij gezien en behandeld te worden. Het geeft een gevoel van vertrouwen als de begeleiders laten merken dat ze zich betrokken voelen met de persoonlijke omstandigheden van asielzoekers en vluchtelingen. Dat ze de culturele achtergronden, persoonlijke ervaring, kennis en capaciteiten van vluchtelingen waarderen, deze niet afwijzen en/of niet als minderwaardig en als teken van achterstand beschouwen. Deze acceptatie betekent dat vluchtelingen zich geaccepteerd en gelijkwaardig voelen en zich kunnen hechten aan de Nederlandse samenleving. In mijn perspectief is er dan pas sprake van communicatie tussen twee gelijkwaardige partijen die elkaars rechten, plichten en grenzen accepteren en vervolgens met elkaar samenwerken. Daarvoor is een proces van bewustwording nodig. Dit betekent dat men zich bewust zou moeten worden van wederzijdse afhankelijkheid van elkaars informatie en kennis. Vervolgens is de verwachting dat beide partijen hier ook naar handelen. Beide partijen hebben informatie die alleen in combinatie met elkaar tot goede en vruchtbare resultaten kan leiden. Bij dit proces van wederzijdse afhankelijkheid, bewustwording en samenwerking nemen de drie begeleidingsfactoren een onmisbare plaats in.

Een ander belangrijk aandachtspunt is dat de verantwoordelijkheidsverdeling helder moet zijn voor beide partijen. Deze verdeling dient rechtvaardig en passend te zijn. De helderheid over het proces en het delen van verantwoordelijkheden betekent niet dat men een rigide werkwijze moet volgen, integendeel. De persoonlijke werkwijze van begeleiders dient vooral gecombineerd te zijn met flexibiliteit en acceptatie van de (on)mogelijkheden van deze groep.

Om vertrouwen te bevorderen, zijn in eerste instantie zowel formele als informele manieren van contact leggen nodig. Met informele contacten bedoel ik een belangstellende, persoonsgerichte, aandacht gevende en empathische manier van communicatie, zoals een luisterend oor hebben, vragen stellen over de culturele achtergrond en het land van herkomst, interesse tonen in de gezinssituatie en culturele waarden en normen van de vluchtelingen. Door deze informele manier van contact en communicatie komt de begeleider dichter bij de persoonlijke wereld en beleving van de vluchteling. Dit schept een individuele en een persoonlijke band. Door een persoonlijke manier van communicatie en contact zullen de vooroordelen verminderen. Als eenmaal een positief contact ontstaat, volgt er in gunstige zin een zichzelf versterkend proces.

De praktische belemmeringen kunnen in een positieve sfeer besproken worden, omdat de vluchteling zich als gelijkwaardig ziet, omdat de vluchteling vertrouwen heeft, inspraak voelt en omdat hij/zij zich geaccepteerd en gerespecteerd ziet in de ogen van zijn/haar begeleider.

Naast het gebruikmaken van de resultaten uit deze studie is het belangrijk om voor het verbeteren van het begeleidingsproces als een proces van gedragsverandering gebruik te maken van nieuwe inzichten en ontwikkelingen uit de cognitieve gedragstherapie en sociale psychologie. Daarnaast zullen migratie- en vluchtelingenstudies een bijzondere 
bijdrage leveren aan betere communicatieve middelen, zowel in de geestelijke gezondheidszorg als voor de scholing en de begeleiding naar de arbeidsmarkt.

\subsection{Beperkingen van de drie onderzoeken}

\subsubsection{Onderzoek 1}

Er is gekozen voor enkele vragenlijsten om de hypothesen van onderzoek 1 te toetsen. Dit is een veelgebruikte methode voor een correlationeel onderzoek.

De hoofdvraag van onderzoek 1 gaat over de kansperceptie van vluchtelingen en asielzoekers naar de positieverbetering in Nederland. De vragen van deze vragenlijst zijn gedeeltelijk gebaseerd op de onderzoeken van anderen met ongeveer vergelijkbare thema's. Inhoudelijk gingen die studies over de thema's die ook interessant zijn voor de arbeids- en organisatiepsychologie en de sociale psychologie.

Bij het samenstellen van de vragenlijst heb ik getracht om diverse vormen van validiteit nauwkeurig in acht te nemen. Validiteit is een ingewikkeld begrip. Voor mijn onderzoek waren van de drie bekende 'drie-eenheidvaliditeiten' vooral de constructvaliditeit en de inhoudsvaliditeit belangrijk. Bij de constructvaliditeit is de centrale vraag of het meetinstrument gericht is op de factoren die het testgedrag verklaren. Met andere woorden: sluit de vragenlijst aan bij de heersende theoretische opvattingen? Mijn intentie was om de constructvaliditeit van de oorspronkelijke vragenlijst verder te vergroten. De schalen van de vragenlijst zijn aangepast aan de specifieke populatie van dit onderzoek. Het was belangrijk om de theoretische inhoud hetzelfde te laten blijven. Dit heeft wel geleid tot opmerkingen van de respondenten over de lengte van de begeleidingsvragenlijst. De herhaling van de vragen in de vragenlijsten ervoeren de respondenten van dit onderzoek over het algemeen als irritant en tijdrovend.

Een andere ingewikkelde kwestie was de inhoudsvaliditeit. Bij de inhoudsvaliditeit is de centrale vraag in hoeverre de inhoud van een vragenlijst de bedoelde kennisgebieden, kennisinhouden en gedragswijzen van de respondenten representeert.

Om de inhoudsvaliditeit van de vragenlijst begeleidingsvariabelen te verbeteren, is de vragenlijst vooraf aan enkele respondenten van de doelgroep voorgelegd met de bedoeling de eventuele onduidelijkheden en begripsmoeilijkheden aan te geven. De vragenlijst is op basis van hun opmerkingen aangepast. Ik heb bewust gekozen voor respondenten met diverse taalvaardigheden en opleidingsniveaus. De schalen zijn tevens aangepast aan de specifieke kenmerken van de doelgroep. Ondanks al deze pogingen om de inhoudsvaliditeit te verbeteren, blijft het overigens altijd de vraag of de items die zijn gebruikt, goede indicatoren zijn van de begrippen die onderzocht worden (Cronbach, 1971; Drenth \& Stijsma, 1990). Wat de begeleidingsvragenlijst betreft, had ik geen vergelijkbare vragenlijst voor deze specifieke doelgroep tot mijn beschikking. De inhoudsvaliditeit en de constructvaliditeit van de verschillende schalen kunnen voor de toekomstige onderzoeken verder worden verbeterd. Daarnaast is het raadzaam om aandacht te besteden aan aspec- 
ten als synthetische validiteit (het feit of validiteitgegevens van de ene naar de andere situatie geëxtrapoleerd kunnen worden) en congruente validiteit (de correlatie van een test met een bekende, als soortgenoot gedefinieerde test; De Groot, 1961; 1994).

Zowel bij onderzoek 1 als bij onderzoek 3 heb ik te maken gehad met het 'non-responsverschijnsel.' De respons was over het algemeen minder hoog dan ik had verwacht. Van alle vragenlijsten die ik Iraniërs heb toegezonden, ontving ik ongeveer $30 \%$ terug. Bij asielzoekers was de kwestie van 'interesse' wisselend. De lage respons kan voortkomen uit verschillende factoren.

Binnen dit onderzoek kunnen redenen voor non-respons onder andere gevonden worden in het onderwerp van deze studie. Onderwerpen zoals integratie, psychopathologie en trauma zijn gevoelige en precaire thema's. Een andere mogelijke oorzaak voor 'lage respons' zou te maken kunnen hebben met de lengte van de vragenlijsten, onder andere de begeleidingsvragenlijst en de SCL-90. Financiële beloning speelde enerzijds een positieve rol, anderzijds ook niet. (Ex-)vluchtelingen weigerden over het algemeen een financiële beloning aan te nemen. Of deze reactie met de culturele achtergrond van Iraniërs te maken heeft, kan ik niet met zekerheid beweren. Voor asielzoekers speelde financiële beloning een rol om deel te nemen aan het onderzoek.

Het is natuurlijk ook mogelijk dat een reden voor non-respons is geweest dat respondenten de vragen niet goed begrepen hebben of de vragen te ingewikkeld hebben gevonden.

Er waren kritische opmerkingen over de inhoud van de vragenlijsten, maar er waren over het algemeen weinig klachten en/of opmerkingen over het begrijpen van de vragen. Ik kan niet achterhalen of deze kritische houding een reden voor 'non-respons' was.

Om eventuele 'common-methode variance' (men is geneigd bij de vergelijkbare vragen steeds meer hetzelfde antwoord te geven) te beperken, heb ik bijvoorbeeld vergelijkbare vragen op verschillende pagina's gezet of de lay-out veranderd. Respondenten hebben wel aangegeven dat ze zich hebben geërgerd aan de herhaling van de vragen. Ik kan niet achterhalen of deze strategische herhaling tot irritatie en vervolgens tot 'non-respons' heeft geleid.

Het is mogelijk dat selectie is opgetreden, wat gevolgen zou kunnen hebben voor de generalisatie van de resultaten. Het is mij niet goed duidelijk of de groep asielzoekers geneigd was om diverse vragenlijsten in te vullen als waren het klachtenlijsten. Het is mogelijk dat men de hoop had op die manier meer aandacht te kunnen krijgen voor de uitzichtloze situatie waarin men zich bevond. Het is niet na te gaan welke invloed een eventuele selectie op meningen van de respondenten heeft gehad. Het is daarom raadzaam om enige mate van terughoudendheid in acht te nemen met het generaliseren van de resultaten van dit onderzoek.

In deze studie is het (modererend) effect van acculturatiestress op de perceptie van kansen niet onderzocht. Dit vormt een beperking. De vraag die dus onbeantwoord blijft, is of acculturatiestress ook sommige resultaten zou kunnen verklaren die nu aan psychopathologie of coping zijn toegeschreven. Het is mogelijk dat de verbanden die in dit proefschrift 
gevonden zijn, ook gevonden kunnen worden wanneer bijvoorbeeld psychopathologie vervangen zou worden door acculturatiestress. Verder onderzoek zal moeten uitwijzen of er overlap bestaat tussen de twee begrippen acculturatiestress en psychopathologie. Daarom is het belangrijk om te onderzoeken welke meetinstrumenten zouden kunnen worden toegepast waarmee differentiaties tussen deze twee begrippen mogelijk worden.

Een van de belangrijkste beperkingen van onderzoek 1 en 2 is dat niet daadwerkelijk integratiesucces is onderzocht, maar alleen de kansperceptie. Hoewel het aannemelijk is dat een positieve perceptie van kansen integratieversterkend gedrag bevordert, zou het belangrijk zijn in vervolgonderzoek dit veronderstelde verband direct te meten. Uit diverse studies blijkt dat optimisme tot een ander gedrag leidt dan pessimisme (Lazarus, 2003; Seligman \& Csikszentmihalyi, 2000; Compton, 2005).

Nog een andere beperking zou te maken kunnen hebben met het maken van onderscheid tussen verschillende subschalen, en voornamelijk de schalen van de begeleidingsvragenlijst. In hoeverre meten de verschillende subschalen wel wat ze verondersteld worden te doen, of meten ze (gedeeltelijk) algemene antwoord-tendenties? Zouden ontevreden respondenten ook hun ontevredenheid uiten door een negatieve score te geven op hun integratiekansen, zodat we eigenlijk geen kansperceptie meten maar ontevredenheid met de begeleiding? In hoeverre zijn de gevonden verbanden wellicht tautologisch? Met andere woorden: drukken de gevonden verbanden algemene ontevredenheid over begeleiding uit?

Het is belangrijk om te benadrukken dat behalve de begeleidingsfactoren andere externe factoren (zoals postmigratiefactoren en zich gediscrimineerd voelen) de kansperceptie op positieverbetering kunnen beïnvloeden. In onderzoek 1 heb ik me beperkt tot het onderzoeken van de relatie tussen ervaren begeleiding en de kansperceptie op positieverbetering. Had ik naar de kansperceptie op positieverbetering in het algemeen gevraagd, dan was de kans groot geweest dat tal van andere factoren deze perceptie zouden beïnvloeden waardoor ik veel minder gerichte hypothesen kon toetsen. Daarom heb ik in de begeleidingsvragenlijst de relatie tussen begeleiding en de kansperceptie onderzocht. Dit kan men als een specificatie beschouwen die de respondenten heeft geholpen om gericht na te denken over het verband/de relatie die ik wilde toetsen. In een onderzoek waarin de effecten van diverse factoren op de kansinschatting op positieverbetering wordt onderzocht, moet natuurlijk die specificatie worden weggelaten.

Ten slotte is het correlationeel karakter van dit onderzoek een beperking. We kunnen niets zeggen over de causaliteit van de gevonden verbanden. Om de causaliteit te toetsen, zouden we een experimentele methodologie moeten gebruiken. Het zou bijvoorbeeld interessant zijn om asielzoekers en vluchtelingen (gestratificeerd) te randomiseren over twee begeleidingscondities, de één de gebruikelijke, de ander een aangepaste, waarvan we verwachten dat deze beter tegemoetkomt aan de behoeften van degenen die moeten integreren. Van zo'n verbeterde begeleiding verwachten we dan niet alleen grotere tevredenheid, maar ook hogere integratie-kanspercepties, en dat is uiteindelijk nog het belangrijkste: meer geslaagde daadwerkelijke integratie. 


\subsubsection{Onderzoek 2: diepte-interviews}

De interviews zijn verricht naar aanleiding van onderzoek 1. Er is een topiclijst samengesteld. Het was mogelijk om met een selectie van de respondenten diep in te gaan op hun persoonlijke ervaring met het onderwerp 'begeleiding'.

In de veilige privésituatie voelden de respondenten zich meer op hun gemak dan in een onderzoekssituatie, waarin de vragenlijsten zijn afgenomen. Dit hebben enkele geïnterviewden na het verloop van de interviews aangegeven. Het afnemen van de interviews in de asielzoekerscentra was toch een belemmering voor het veiligheidsgevoel van de asielzoekers. Sommige geïnterviewde asielzoekers hebben me gevraagd of ik ze op een andere locatie wilde interviewen. Mijn hypothese is dat deze respondenten de interviewsituatie vergeleken zouden hebben met het afnemen van interviews door de IND.

Kwalitatief onderzoek kent over het algemeen een bekende beperking. Dit heeft te maken met het aspect representativiteit. Een kwalitatief onderzoek is niet representatief in de statistische zin van het woord: we kunnen niet dus op basis van een kwalitatief onderzoek automatisch uitspraken doen over de totale populatie van onze steekproef. Het gaat vooral om de representativiteit in inhoudelijke zin.

Het is wel mogelijk om enkele belangrijke aspecten na te streven bij zowel de selectieprocedure als bij het interpreteren van de gegevens. Ik heb stappen gezet om de representativiteit van het onderzoek te vergroten:

- Ik heb respondenten op diverse manieren (zowel telefonisch als mondeling als schriftelijk) benaderd om mee te doen aan het onderzoek. 20 mensen hebben uiteindelijk meegedaan aan het onderzoek: een redelijk goede deelname.

- Ik heb doelbewust naar contrasterende gevallen gezocht met diverse demografische en individuele aspecten zoals leeftijd en opleidingsniveaus.

- Ik heb doelbewust gekozen om de gebeurtenissen systematisch te ordenen. Dit was niet altijd even gemakkelijk met betrekking tot de interpretatie van de verhalen. De verhalen waren zo nu en dan zeer emotioneel geladen en daardoor verliep het ordenen van het materiaal moeizaam.

De interviews zijn gebruikt om een aantal begrippen nader uit te werken. Ik ben van mening dat de interviews een illustratief beeld geven van de subjectieve beleving van de respondenten: een illustratief beeld van de wijze van denken, maar vooral van de emoties van respondenten. Dit heeft volgens mij te maken met het semigestructureerde karakter van onderzoek 2 .

Het opnieuw doen herinneren van wat men heeft meegemaakt in het land van herkomst, de verliezen die men heeft geleden, de gebeurtenissen tijdens de asielperioden, liet de respondenten natuurlijk niet onberoerd. Er kwam dan ook veel los. Dit heeft wel geleid tot veel pijnlijke confrontaties en gevoelens. De reacties van de geïnterviewden riepen bij mij betrokkenheid en begrip op, maar waren soms belastend voor mij en het was soms moeilijk om professionele distantie te bewaren.

Ik zet hieronder enkele kanttekeningen bij onderzoek 2 die ook beschouwd mogen worden als de beperkingen en/of kritische aantekeningen bij onderzoek 2. 
- Vergelijken en onderscheid maken: ik weet weinig over de werkelijke opvang van asielzoekers en vluchtelingen binnen Europa. Is de opvang van vluchtelingen en asielzoekers elders in Europa anders geregeld en zou men daar andere antwoorden krijgen op dezelfde soort vragen? Valt er te destilleren hoe een opvang in de meest ideale vorm hoort te zijn? Hoe is de opvang elders georganiseerd, onderzocht en beoordeeld? Deze vragen kan ik niet op basis van mijn onderzoek beantwoorden.

- Mijn rol als interviewer: ik weet niet wat zou er gebeuren met de antwoorden op de vragen als ik ze niet had gesteld maar iemand anders. Heb ik de rol van een advocaat of een vertegenwoordiger op me genomen?

- Mijn functie als interviewer: ik heb me steeds afgevraagd hoe de respondenten me hebben gezien, ervaren en beoordeeld en wat ze verwachten van de antwoorden die ze gaven. Het blijft erg moeilijk om al deze facetten te achterhalen, laat staan te controleren.

- Plaats van interviews: ik heb me afgevraagd of de antwoorden te maken zouden kunnen hebben met de plaats van interviews en de plaats van opvang. Mensen worden natuurlijk beïnvloed door het systeem om hen heen. Geven de antwoorden van de respondenten ook een beeld van die bepaalde plaats en vooral van een asielzoekerscentrum?

- Tijd en proces van het onderzoek: onderzoek is ook een tijdsbeeld. Het onderzoek is nu alweer een tijd geleden. Zou het interessant zijn om dezelfde mensen enkele jaren na dato opnieuw te ondervragen? Hebben ze een andere mening over de begeleiding? Is er een correlatie tussen de tijd, de antwoorden en de waarneming, en hun begeleiding? Wat is de invloed van de maatschappelijke context op de factor tijd? Deze vragen kan ik niet met zekerheid beantwoorden.

- Mijn rol als observator: hebben mijn ideeën, mijn indrukken, mijn sfeerbeelden als aspecten van mijn eigen verwerkingsproces effect gehad op vermelde resultaten?

- Mijn positie als een lotgenoot: welke gevoelens en gedachten hebben de geïnterviewden over mij als een succesvol en geïntegreerde landgenoot? Heeft mijn positie naast hun bewondering ook bij sommige deelnemers defensieve reacties teweeggebracht, waardoor ze de vragen selectief hebben beantwoord?

Ik kan deze vragen niet beantwoorden op basis van wetenschappelijk verantwoorde metingen.

\subsubsection{Onderzoek 3}

Zoals eerder is vermeld, heeft onderzoek 3 vorm gekregen naar aanleiding van de uitkomsten van onderzoek 1 , nadat de analyses van de resultaten van de psychologische factoren van onderzoek 1 zijn gedaan. De vraag rees namelijk waarom respondenten zo hoog scoren op diverse psychopathologieschalen en of deze resultaten te maken zouden kunnen hebben met de meegemaakte trauma's. Bij de selectie van de meetinstrumenten was mijn aandacht gericht op enkele vragenlijsten waarmee een beter beeld te verkrijgen 
is van de mate van psychopathologieklachten. De twee vragenlijsten UCL en SCL-90 had ik al eerder gebruikt bij onderzoek 1. Daarnaast zijn er twee traumavragenlijsten, HTQ en PSS, gebruikt. De genoemde beperkingen wat betreft de construct- en inhoudsvaliditeit zijn hier minder van toepassing omdat de gebruikte vragenlijsten al bestaande standaardvragenlijsten zijn en de schalen van de vragenlijsten een betere betrouwbaarheid hebben dan de door mij samengestelde begeleidingsvragenlijsten. Alle gebruikte vragenlijsten worden in de klinische praktijk en bij onderzoeken regelmatig gebruikt.

Non-respons vormt voor onderzoek 3 ook een beperking.

Respondenten hadden kritische opmerkingen met betrekking tot de wijze waarop de HTQ-vragen samengesteld zijn. De ingewikkelde samenstelling van de vragen en een slechte vertaling benoemden de respondenten als de zwakke kanten van de HTQ. De respondenten waren beduidend meer tevreden over de inhoud en de samenstelling van de vragen van de PSS.

Ik kan op basis van de vragenlijstresultaten geen onderscheid maken tussen voor en na de migratiegebeurtenissen. Ook is het niet mogelijk om een duidelijk onderscheid te maken tussen 'life events' en de meegemaakte trauma's. Respondenten beschouwen hun moeilijke en onzekere periode in asielzoekerscentra als trauma's, terwijl men in de classificatie van DSM-IV een andere definitie voor trauma en PTSS hanteert.

Een andere beperking heeft te maken met de normering van de HTQ. Respondenten van deze studie komen uit een gewone populatie van Iraanse vluchtelingen en asielzoekers. De normen die ik heb gebruikt, zijn gebaseerd op de resultaten van een klinische populatie. Dit eist enige mate van terughoudendheid met betrekking tot de interpretatie van de resultaten.

In deze studie is verder geen gerichte aandacht besteed aan de acculturatieaspecten. Dit betekent dat het effect van acculturatie op psychopathologie en PTSS-klachten niet onderzocht is. Dit is een beperking van deze studie. Vooral omdat de hoge mate van angst en depressie niet direct lijkt voort te komen uit PTSS, rijst de hypothese dat ze samenhangt met verschillende acculturatieaspecten. Deze hypothese kon niet worden getoetst, behoudens de samenhang met status.

Onderzoek 3 was ook een correlationeel onderzoek. Er zijn diverse correlaties berekend tussen de vier vragenlijsten. Correlatie is niet hetzelfde als causaliteit (Milles \& Shevlin, 2001; Miles, 2005). Er bestaat een risico dat men een causale link gaat leggen tussen bijvoorbeeld een bepaalde soort coping en psychopathologie en/of PTSS-klachten, of tussen verblijfsstatus en psychopathologie.

Aangezien het huidige onderzoek heeft plaatsgevonden onder Iraanse (ex-)vluchtelingen en asielzoekers, kunnen de resultaten niet direct worden gegeneraliseerd naar de gehele vluchtelingenpopulatie. Het is denkbaar dat de andere vluchtelingengroepen met bijvoorbeeld een zeer collectieve culturele achtergrond andere behoeften en meningen hebben dan Iraniërs die een semi-individueel en semicollectivistische culturele achtergrond hebben. Dit geldt ook voor vluchtelingen die uit oorlogsgebieden/landen afkomstig zijn en/of langdurige oorlogen hebben meegemaakt. Toekomstige onderzoeken zul- 
len dan ook uitwijzen in hoeverre de resultaten van deze studie generaliseerbaar zijn naar andere vluchtelingengroepen.

In deze studie (onderzoek 1 en 3) zijn de normgegevens van de normale Nederlandse populatie gebruikt. De scores van de respondenten zijn niet vergeleken met de normgegevens van de normale Iraanse populatie in Iran. Dit heeft te maken met het gebrek aan goede vergelijkbare Iraanse normgegevens. Ik heb contact opgenomen met twee grote bedrijven die zich bezighouden met de ontwikkeling en normering van diverse psychologische vragenlijsten (Azmonyar en Ravantajhiz). Voor de SCL-90 zijn er wel normgegevens beschikbaar voor de adolescenten- en jongvolwassenengroepen (15-26). Deze normen zijn niet geschikt voor mijn onderzoeksgroep vanwege het andere leeftijdbereik. Er bestaan ook Iraanse normgegevens voor verslaafden (psychiatrische patiënten). Deze normgegevens heb ik niet gebruikt omdat de respondenten van mijn studies tot de normale Iraanse populatie behoren. De BDI-normen die in Iran worden toegepast, komen gedeeltelijk overeen met de normen van de Nederlandse populatie.

Samengevat heb ik de Nederlandse normen gebruikt vanwege het ontbreken van geschikte Iraanse normen, en op basis van de aanname dat omdat de respondenten al jaren in Nederland wonen deze normen acceptabel zijn. De context van hun leven is immers "Nederland"; ze wonen niet meer in Iran, en velen kregen verblijfsvergunningen wat pleit voor het gebruik van Nederlandse normen .

\subsection{Implicaties voor vervolgonderzoek}

Er zijn verschillende richtingen van vervolgonderzoek denkbaar. Het verdient aanbeveling om in vervolgonderzoek na te gaan of het toepassen van de inzichten van dit proefschrift ook in de praktijk tot verbetering van het begeleidingsproces leidt. Het is vooral zinvol om stil te staan bij de causaliteit van het effect van de begeleidingsfactoren op een succesvolle integratie. Daarnaast kan onderzoek worden gedaan naar het verband tussen specifieke aspecten van begeleidingsvariabelen en psychisch (on)welbevinden van migranten en vluchtelingen.

Onderzoek 1 is in eerste instantie opgezet om de formele begeleiding te onderzoeken. Het ging over begeleiding die respondenten hebben ontvangen van diverse maatschappelijke instanties (gezondheidszorg, werk en scholing). Het verschil tussen formele en informele begeleiding werd pas tijdens het verrichten van het kwalitatieve onderzoek 2 duidelijk, en toen was het kwantitatieve onderzoek 1 al bijna uitgevoerd. Later, tijdens onderzoek 2 , bleek dat de respondenten een groot verschil ervoeren tussen de formele en de informele begeleiding. De kwalitatieve studie 2 bracht nog meer aan het licht dat van tevoren niet bedacht was in het opzetten van de kwantitatieve studie.

Naast verschillen tussen formele en informele begeleiding, bleken sommige psychologische kenmerken van begeleiding als rationele en affectieve aspecten een rol te spelen. Achteraf gezien was het inderdaad interessant geweest om apart naar de verschillende 
vormen van begeleiding (cognitieve en rationele, affectieve en emotionele aspecten) te vragen. Een nieuw onderzoek zou nodig zijn om deze verschillende soorten begeleiding in een kwantitatief model te toetsen. Hopelijk zal in de toekomst bij een vervolgstudie aandacht worden besteed aan deze affectieve aspecten. In een eventueel nieuw onderzoek zou het raadzaam zijn deze aspecten in de metingen mee te nemen. Achteraf gezien was het beter geweest het kwalitatieve onderzoek eerst te verrichten, omdat dat informatie had opgeleverd die in de opzet van het kwantitatieve onderzoek meegenomen had kunnen worden. Hopelijk zal deze ervaring worden meegenomen in eventueel vervolgonderzoek.

Dit proefschrift kan geen uitspraken doen over causaliteit, ondanks het feit dat dit aspect van groot belang is. Uit de resultaten van deze studie blijkt dat tevredenheid over begeleiding samenhangt met een betere en hogere kansperceptie. Het is dus goed mogelijk dat (ex-)vluchtelingen en asielzoekers baat hebben bij een begeleiding die zowel cognitief als affectief gericht is en de culturele achtergrond van cliënten voldoende betrekt bij het proces van begeleiding. Dit betekent dat de begeleiders trainingen zouden moeten volgen om hun communicatieve vaardigheden en/of stijlen te verbeteren.

Voor een vervolgonderzoek kan bijvoorbeeld gedacht worden aan een experimenteel design, waarbij een experimentele groep begeleiders voordat ze (ex-)vluchtelingen en asielzoekers gaan begeleiden, getraind wordt in deze specifieke aspecten van begeleiding. Een controlegroep krijgt deze training niet en bestaat uit andere begeleiders die ook deze doelgroep zullen begeleiden. Na een bepaalde tijd kan dan een vergelijking plaatsvinden tussen de resultaten van de begeleiding van deze twee groepen, bijvoorbeeld of de experimentele training heeft geleid tot een beter en effectiever integratieproces.

In de training dient men vooral aandacht te besteden aan het opbouwen van vertrouwen, openstaan en bevorderen van inspraak, aandachtig luisteren, het geven van effectieve en gerichte informatie, en het werken aan een rechtvaardige procedure. Deze aspecten beschouw ik als de cognitieve aspecten van een rechtvaardige begeleidingsprocedure. Daarnaast zijn de affectieve en communicatieve aspecten van begeleiding zeer belangrijk voor de begeleiding van asielzoekers en vluchtelingen zoals deze beschreven zijn onder informele begeleiding. Het is naar mijn mening belangrijk om bij het opstellen van het trainingsprogramma ook stil te staan bij individuele en persoonlijke ervaringen van de begeleiders met de doelgroep.

Affectieve componenten van de begeleiding zijn door de respondenten erg belangrijk gevonden en deze vormen volgens een nog niet getoetste hypothese een succesfactor voor een goede begeleiding. Het onderzoek daarnaar zou gebruik kunnen maken van de hechtingstheorie en kunnen toetsen of hechtingsprocessen hierin een cruciale rol spelen.

Nadere verdieping in de thema's en de begrippen, zoals vertrouwen, inspraak, rechtvaardigheid en positieverbetering in het proces van de begeleiding, zou kunnen helpen om een stimulerend en een succesvol begeleidingsproces tot stand te brengen: begeleiding die de kansperceptie van de vluchtelingen verder verhoogt.

Zowel cognitieve en gedragspsychologie als sociale en crossculturele psychologie kun- 
nen vanuit diverse perspectieven dit thema verder onderzoeken. Het gaat daarbij niet alleen om het kwantificeren van een succesvol integratieproces, maar vooral ook om de subjectieve beleving en de persoonlijke tevredenheid. Een combinatie van kwalitatieve en kwantitatieve onderzoeken zal naar mijn mening een beter beeld van de verschillende aspecten, perspectieven en de persoonlijke ervaringen van respondenten tot stand brengen.

Naar de informele en individueel gerichte begeleiding zijn weinig onderzoeken verricht. Deze vorm van begeleiding is door de Iraanse respondenten van deze studie zeer gewaardeerd. Nadere verdieping in deze vorm van begeleiding zal waardevolle informatie verschaffen voor de formele begeleiding.

Op het gebied van psychopathologie en traumatologie denk ik bijvoorbeeld aan meer aandacht voor de etiologie van depressie en angst, een betere en tijdige diagnose van diverse psychopathologieklachten en preventieprogramma's voor asielzoekers. Het is aan te bevelen om na te denken hoe opvang, procedure en integratie zo ingericht kunnen worden dat mensen minder angstig en depressief worden. De rol van sociale steun, de rol van de hechtingstheorie bij het proces van 'vlucht en migratie', en de individuele psychologische en biologische kwetsbaarheid van de vluchteling verdienen meer aandacht, vooral in het kader van preventie.

In deze studie is niet gekeken naar de veranderingen in psychopathologische symptomen binnen de groep van asielzoekers en vluchtelingen die beide keren aan het onderzoek hebben deelgenomen. Dat dit niet tot stand is gekomen, is om de volgende redenen:

Onderzoek 3 is een cross-sectioneel correlationeel onderzoek. In het onderzoek is gekeken naar de algemene psychopathologie- en PTSS-klachten van twee groepen. Het onderzoek gaat primair om de vraag of PTSS de hoge psychopathologieklachten kan verklaren, en niet om de vraag of verandering in status (het verkrijgen van een verblijfsvergunning) leidt tot een vermindering van psychopathologische klachten.

De verklaring dat de stress van de asielzoekers wellicht een oorzaak van de klachten is, is een post-hoc-hypothese. Het klopt dat deze onderzocht had kunnen worden door longitudinale bestudering van psychopathologieklachten en de relatie tussen dat beloop en diverse vormen van stress tijdens de procedures en het verblijf in asielzoekerscentra, alsmede de status. In zo'n onderzoek zou men aandacht kunnen besteden aan de relatie tussen diverse stressfactoren (zoals de duur van het verblijf, onzekerheid over de verblijfsvergunning, hygiënische omstandigheden en privacy in asielzoekerscentra) en het ontwikkelen van psychische klachten en PTSS-klachten. De onderzoeksgroep kan in diverse fasen van het verblijf in Nederland onderzocht worden, bijvoorbeeld gedurende de asielprocedure, een jaar nadat men de verblijfsstatus heeft ontvangen en 3 jaar later. In de studie van Laban et al. (2008) is het effect van diverse stressfactoren op de psychische klachten van de Irakese asielzoekers onderzocht.

Onderzoek naar verschillende copingpatronen zou ook interessante uitkomsten kunnen opleveren. Ik denk bijvoorbeeld aan de combinatie van het bevorderen van actieve coping met het leren om zichzelf gerust te stellen of sociale steun te zoeken, en zich minder pas- 
sief op te stellen in sociale en interpersoonlijke communicatie. Ik denk hierbij ook aan het geven van diverse trainingen gedurende het proces van begeleiding. Een evenwichtige combinatie van oplossingsgerichte en emotiegerichte coping zou op lange termijn een buffer kunnen zijn tegen psychische klachten.

Het geven van diverse trainingen die enerzijds rekening houden met een traumatische en moeilijke voorgeschiedenis van deze groep, maar anderzijds vooral de krachten benaderen, zou kunnen leiden tot een vertrouwelijke en veilige sfeer voor de begeleiding. Dit kan ook leiden tot het verminderen van diverse psychopathologische klachten. Een voorbeeld van deze trainingen is empowerment training, waarin vooral de (innerlijke en persoonlijke) krachten benadrukt worden.

Resumerend is het belangrijk om ons te realiseren dat een goede begeleiding zowel voor gezondheidsinstellingen als voor andere maatschappelijke organisaties belangrijk is. Het gaat om een multidimensioneel proces. Een breed proces van attitude- en gedragsverandering tot het bevorderen van interculturele en communicatieve vaardigheden.

Het is aan te bevelen om in vervolgonderzoeken aandacht te besteden aan de relatie tussen tevredenheid over de begeleiding, de kwaliteit van leven en de mate van psychopathologie van asielzoekers en vluchtelingen. Leidt bijvoorbeeld het verminderen van stress in het leven van vluchtelingen en asielzoekers tot het verminderen van psychopathologie? Leidt meer tevredenheid over begeleiding naar een betere kwaliteit van leven van asielzoekers en vluchtelingen?

\section{Besluit:}

De belangrijkste bevinding van dit onderzoek is het belang van de drie begeleidingsvariabelen (vertrouwen, rechtvaardigheid en inspraak) voor de kansperceptie op een succesvolle integratie.

Het blijkt verder dat de respondenten van deze studie veel waarde hechten aan 'communicatieve en affectieve componenten' van hun begeleiding. Ik hoop dat deze bevindingen iets kunnen betekenen voor de praktijk van de begeleiding en voor de organisaties die zich bezighouden met begeleiding van vluchtelingen en asielzoekers.

Zorgwekkende bevindingen van deze studie zijn de hoge mate van angst en de hoge mate van algemene psychopathologische klachten van de respondenten. Vooral de hoge mate van psychopathologie van asielzoekers en respondenten met een pardonregeling is zorgwekkend. Voor de klinische praktijk is het van belang om meer onderzoek te verrichten naar psychopathologie bij diverse vluchtelingengroepen. In het vervolg zou ook meer gebruik kunnen worden gemaakt van andere gedrags- en cognitieve vragenlijsten in combinatie met bijvoorbeeld hechtingsinstrumenten

Uit de resultaten van dit proefschrift blijkt dat leeftijd de enige moderator is in de relatie tussen de mate van tevredenheid over de begeleiding en de kansperceptie. Dit zou van belang kunnen zijn voor verder onderzoek en in het kader van preventie. 
Langetermijneffecten van bijvoorbeeld een goede begeleiding zouden vaker moeten worden onderzocht. Verder zou er kunnen worden gekeken naar voorspellende variabelen en met name copingstijlen om te onderzoeken hoe preventieve methoden kunnen worden ontwikkeld en toegepast bij het verbeteren van zowel psychische gezondheid van vluchtelingen en asielzoekers als voor een betere begeleiding.

Ik hoop dat beleidsmakers er meer van overtuigd raken dat het investeren in preventie en effectieve begeleiding veel vruchten afwerpt.

Last but not least kan gezegd worden dat het snijvlak tussen klinische psychologie, crossculturele en sociale psychologie een boeiend veld van onderzoek is. Hopelijk vormen de uitkomsten van deze studie een aanzet tot het verrichten van meer integratieve onderzoeken. 


\section{Summary}

For the past two decades, Western countries in particular have been facing an influx of migrants and refugees. The character of migration from 'non-Western' countries in recent decades has shifted from labor-related to asylum-related migration. In most European countries, the 'refugee issue' is high on the political agenda.

On January 1, 2010, there were 16 million inhabitants in the Netherlands. Over the last five years, immigrants have become one-third of the population in the Netherlands. According to data from the Central Bureau of Statistic (CBS, 2008), the percentage of non-Western immigrants has risen from $7.6 \%$ in 1996 to $19 \%$ of the population in 2007. In 2015, it is predicted that the Netherlands will have 3.5 million immigrants and $40 \%$ will be from Third World countries.

One in five Dutch residents is an immigrant, although half were born in the Netherlands and are a second generation. The proportion of 'non-Western'immigrants in the total population has gradually increased over the last ten years. Somalis, Afghans, Iraqis, and Iranians are the four largest non-Western populations in the Netherlands and they mainly migrated for political and humanitarian reasons (Annual Report Integration 2010).

In 2010, 13,300 thousand people requested asylum in the Netherlands - a drop from 2009. However, the top four countries for asylum-seekers (Somalia, Afghanistan, Iraq, Iran) have not changed. The CBS figures also show that unlike the other three countries, the number of asylum-seekers from Iran increased by $13 \%$ in the first quarter of 2011 compared to the same time period in 2010 (CBS, 2011).

CBS reports that there were 11,731 naturalized Iranians in the Netherlands on January 1, 2000. The reasons for their flight from Iran included: fear of persecution, threats and the loss of freedom due to the fundamentalist regime. On January 1, 2010, there were 39,000 Iranians living in the Netherlands. Displaced Iranians generally come to the Netherlands from large cities, speak English and have a good educational background. When in Iran, these refugees were part of a modern population and generally lived a Western lifestyle. Unfortunately, their former high life style in Iran is not possible in the Netherlands. My decision to research Iranian refugees is primarily motivated by the fact that I am an Iranian (former) refugee, and emotionally involved with my compatriots. I am also interested in the experiences of the refugees in the Netherlands.

This dissertation consists of three studies. Studies 1 and 3 are quantitative research and study 2 is qualitative research. The three studies investigated Iranian (ex-)refugees and asylum-seekers between 2004-2010. 
Data for study 1 was collected from 2004-2006. During that period there were 72 Iranian asylum-seekers and 76 (former) Iranian refugees throughout the Netherlands surveyed using four questionnaires. Three standard questionnaires included the Beck Depression Inventory (BDI), Utrecht's Coping List (UCL), and the Symptoms Check List (SCL-90) and a fourth questionnaire was self-designed and called the 'guidance questionnaire'.

The central question of study 1 is whether Iranian refugees and asylum-seekers see any relationship between the guidance variables (trust, participation and fair procedure) and their perception of their chance to integrate into the Netherlands. The study further examined the moderation effects of both psychological variables (depression, coping style and psychopathology) and individual variables (gender, age and residence status) on the relationship between contentment about guidance and the respondents' perceptions of their chances for integration. The effect of moderating variables on the respondents' perception of their chance to integrate was tested.

A moderator is a qualitative or quantitative variable that effects the direction and/or the strength of the relationship between predictor(s) and the dependent variable. I called these variables 'individual and psychological variables'. Individual variables included the respondents' demographic characteristics (gender, age) and residence. The degree of depression (measured by the $\mathrm{BDI}$ ), the applied coping style (measured by the $\mathrm{UCL}$ ) and general psychopathology (measured by SCL-90) of the respondents that I called 'psychological variables' were all examined. Study 1 included regular comparisons between (ex-)refugees who had obtained a residence permit and asylum-seekers who did not have a residence permit.

I examined whether these variables had a moderating effect on the relationship between the independent variable: guidance (composed of three variables: fair procedure, trust and participation) and the dependent variable: perception of their chance to integrate. I made a new variable for the three guidance variables, which I named the 'satisfaction variable'. In addition to the psychological variables, I also examined the demographic characteristics of the respondents and if they had any effect on the perception of their chance to integrate.

In study 1, it was assumed that a good and efficient guidance would have a significant effect on the refugees' perceptions of chance of successful integration.

By guidance, I include both the official assistance the Iranian refugees receive during their integration process, as well as the support of various non-profit organizations and the Dutch population. The latter form of guidance, in many cases, is not targeted and/or official; thus, in this study, this type of guidance is described as 'non-formal guidance'.

For this dissertation thesis, the subjective manner in which Iranian (former) refugees and asylum-seekers integrate based their guidance experience is central. In my opinion, successful guidance means that the refugees feel that guidance in Dutch society offers them better opportunities to build a good life.

Guidance is an integral part of the integration process such that an interactive process between a coach/consultant and a refugee allows the refugee to choose from many options for their future - a road that is compatible with his/her personal situation. In refugee 
guidance, the emphasis is to imagine a process of providing information, advice, support, as well as referrals for therapy and treatment if necessary. In my view, guidance yields a good outcome. Good integration support ultimately has the effect of a (more) successful integration. When analyzing the role of the guidance, I make the following distinctions.

First, I make a distinction between two phases for refugees in the Netherlands. In the first phase, the asylum-seeker has no status, no home, no right to education and no work. In the second phase, the refugee becomes a citizen with a Dutch residence permit, the right to education and housing, and the right to social security and benefits if he/she has a job. In my second distinction, I assume that refugee integration is a lengthy process. This process is, I assumed, under the influence of two groups of factors (variables):

1- The first group of factors (external factors) are guidance factors, such as the refugees' experiences and has to do with the way the refugees are accompanied. To what extent do they experience being listened to and having a say in decisions that affect them? To what extent do they believe that the guidance procedures are applied fairly and equitably? To what extent do they trust the way they are supervised?

2- The second group of factors (internal factors) are individual and psychological factors. Individual factors include demographic factors like gender, age, as well as the process of obtaining a residence permit. As psychological factors, I investigated the degree of psychopathology, depression and coping styles of the respondents and to what extent these factors affected the respondents' perceived chance to integrate into Dutch society.

The findings of study 1 show that there is a significant relationship between contentment with guidance variables and the respondents' perception of their chance for a successful integration. The three guidance variables (i.e. trust, participation and fair procedure) have a high correlation with the respondents' perception of their chance for integration: asylum-seekers see less of a chance to integrate than (ex-)refugees. The results further show that age is the only variable with a moderating effect on the relationship between the respondents' contentment about guidance and the perception of their chance to integrate. Younger respondents who were less satisfied with their guidance have also a relatively lower perception of chances than older respondents who were little satisfied with their guidance. For all other individual factors (gender, residence) and psychological variables (depression, coping style and general psychopathology), no moderating effects were found. However, significant direct effects on chance perception were found for residence and active coping style. It also appeared that asylum-seekers report more psychopathological complaints than refugees with a residence permit.

Study 2 was a qualitative research study. In-depth interviewing was performed to investigate the respondents' subjective perception of their chance (with guidance) for successful integration. The individual perception of the respondents to integrate with guidance is the key element of study 2 . The study used in-depth interviews with both asylum-seekers and (former) refugees. There was a topic list with five clusters. The questions from each cluster were addressed in an explicit in-depth interview. 
Respondents for study 2 had already completed four questionnaires in study 1 and the in-depth interviews were a follow-up to their original questionnaire responses. Each interview lasted approximately three hours. The questions were written with a focus on variables that were relevant to this study: cultural aspects, acculturation strategies and the respondents' personal experience with issues such as discrimination.

The interviews revealed that many respondents appreciated the guidance variables (trust, fair procedure and participation). They agreed that guidance plays a crucial role in the integration process. The results of the interviews also showed a negative and pessimistic picture of formal guidance. Respondents were asked about their individual and personal experience of managing integration. Results demonstrated that respondents generally did not feel understood by their consultants. In many cases, they felt abandoned and sometimes discriminated against. Some respondents described formal guidance as aloof, business-like, and sometimes not relevant.

The findings of study 2 show that the interviews make a distinction between formal and informal care support. The interviewees were most critical of the formal care support that is dispassionate and impersonal and not always in line with the interviewees' wishes and abilities.

Study 3 is a quantitative and a correlational research in which I investigated the degree of the respondents' psychopathological complaints. Study 3 was performed from 2008-2010 and was conducted among 119 Iranian refugees. The sample consisted partly of respondents who had also participated in study 1 . The difference in survey 1 respondents and those in study 3 was that all respondents in study 3 were in possession of a residence permit. Asylum-seekers who had participated in the first study, now (in study 3 ) had had a residence permit for a certain period of time. This was largely due to an offer of amnesty in 2008; thus half of the respondents in study 3 had qualified under the pardonregeling (amnesty) and received residence permits. The intention of study 3 was to provide the best possible picture of the mental health of the respondents, who had already participated in the first correlational research in 2004-2007.

It was examined whether there were any differences between the two groups of respondents in study 3: one group with a permanent residence permit and a second group with a temporary residence permit. In study 3 , I focused on psychopathological symptoms and in particular on posttraumatic stress disorder (PTSD). The outcome of an investigation of results from studies 1 and 2 was the main reason for conducting study 3 . High levels of psychopathological symptoms were reported by the respondents from the surveys in studies 1 and 2, and I wanted to determine to what extent this was due to PTSD. In study 1 , PTSD and PTSD symptoms were not measured. For study 3 , I used standard questionnaires namely the Utrecht Coping list (UCL), Symptom Check list (SCL-90), the trauma Questionnaire (HTQ) and Posttraumatic Symptom Scale (PSS). The last two questionnaires were used to measure PTSD for the respondents.

The findings of study 3 show that that the respondents had in general many psycho- 
pathological complaints. It also showed that the majority of respondents have increased anxiety, but not necessarily a high enough score on the PTSD questionnaires to fall within the standard for a diagnosis of PDSD. The main hypothesis for study 3 was therefore rejected. The extent of the respondent's PTSD complaints was not high enough to conclude that they satisfied the diagnosis of PTSD.

The analysis also showed that the extent of depression and anxiety complaints, in particular, was high in all respondents.

\section{General conclusions}

The results confirm the hypothesis that the three guidance variables trust, participation and justice have a high correlation with chance perceptions for successful integration. This finding indicates how guidance can be improved to enhance integration. However, although theoretically we can expect that a positive expectation affects integration behavior and thus actual integration, further research is needed to prove this.

Asylum seekers were shown to perceive fewer opportunities to integrate than the (former) refugees.

This finding could be related to the effects of some factors such as post-migration factors and the uncertainty of the asylum seekers about their permits.

The results show that age is the only variable with a moderating effect on the relationship between satisfaction with guidance and the respondents' chance perception. Younger respondents who were less satisfied with their guidance have a relatively lower perception of chances than older respondents who were little satisfied with their guidance. This may indicate that the younger people need more and stronger support, for example to help them to actively participate in the labor market.

Although no other variables were found that had a moderating effect on the relationship between satisfaction with guidance and chance perceptions, there were direct links. For example psychopathology had a negative relationship with perception of chances for successful integration. This might indicate that in cases with elevated levels of psychopathology, it might be helpful to treat the psychopathological problems so that expectations are increased and successful integration is stimulated.

The qualitative study 2 confirmed that the respondents believe that the three variables trust, participation and justice are important for guidance. This is important as this was an assumption in study 1 that needed validation.

The main finding of this study is that informal guidance is judged as more valuable than formal guidance by many respondents. This raises the question of whether formal guidance can be improved, taking advantage of what the respondents value as informal guidance (eg, equality, highlighting their strengths, etc.); or whether this preference is caused by inherent characteristics of formal guidance. In the latter case, perhaps the whole 
system of formal guidance should be replaced by an informal guidance system.

The results of the first two studies show that respondents who are more inclined to apply active coping, perceive more chances for successful integration. This may mean that the use of active coping in practice has a significant effect, such as more contact with and support from Dutch organizations (authorities) and Dutch inhabitants. This would probably give the respondents a feeling of more competence. They would then assess their chances for integration more positively.

The analysis also shows that passive coping significantly correlates with psychopathology in general. This could indicate that passive coping increases psychopathology, and/ or that psychopathology increases passive coping, for instance by intensifying feelings of powerlessness and vulnerability. A probable interpretation is that of a vicious circle by which psychopathology and psychopathology reinforce each other.

For the practice of guidance, the findings give an indication that one should pay more attention to promoting active coping, for example being more active during the asylum-seeking process, learning the Dutch language, and calling for help and support upon arrival in the Netherlands. Nevertheless, the uncertainty of a residence remains as probably one of the most important pathogenic factors. This raises the question of how much influence asylum seekers people can exert in practice to reduce psychopathological symptoms as long as this uncertainty remains.

The results of the two studies show that respondents appreciate emotional and personal guidance. This means that a coach who is not detached, but rather is emotionally involved, and shows an interest in cultural background and needs of respondents, is better able to provide a sense of security, which in turn strengthens the expectations of a successful integration.

We conclude that a safe and personal approach to guidance creates secure attachment opportunities, which apparently is important for good coaching results. This can create a difficult situation in practice, because there is interaction between two parties each with their own attachment style. The expectation is that a coach who is securely attached, is better able to communicate with clients with a problematic history, and can provide a more secure attachment even to these more problematic clients.

The findings of the three studies show that respondents had many psychopathological symptoms. The degree of depression and anxiety symptoms of the respondents is particularly high. The degree of PTSD symptoms of the respondents is not high enough to conclude that they meet the diagnosis of PTSD and makes it unlikely that their high level of general psychopathology came from PTSD. Prolonged stress during the asylum procedure and acculturation-stress seem to be better explanations for the high degree of psychopathology. If this is true, guidance and the entire asylum process should focus more on reducing the stress caused by the asylum procedure and the acculturation. 


\section{Samenvatting}

Dit proefschrift bestaat uit drie onderzoeken. Onderzoek 1 en 3 zijn correlationeel en kwantitatief en onderzoek 2 is een kwalitatief onderzoek. De drie onderzoeken hebben in de periode 2004-2010 onder Iraanse (ex-)vluchtelingen en asielzoekers plaatsgevonden.

De centrale vraag van onderzoek 1 is of de Iraanse vluchtelingen en asielzoekers relaties zien tussen de begeleidingsvariabelen (vertrouwen, inspraak en rechtvaardige procedure) en hun kansperceptie om succesvol in Nederland te kunnen integreren. Onderzoek 1 is verder uitgevoerd naar de modererende effecten van zowel psychologische variabelen (depressie, copingstijl, psychopathologie) als de individuele variabelen (geslacht, leeftijd en verblijfsstatus) over de relatie tussen tevredenheid over begeleiding en de kansperceptie van de respondenten. In onderzoek 1 zijn regelmatige vergelijkingen gemaakt tussen (ex-)vluchtelingen met een verblijfsvergunning en asielzoekers zonder een verblijfsvergunning.

Onderzoek 2 is een kwalitatief onderzoek. Door middel van diepte-interviews werd onderzoek gedaan naar de subjectieve beleving van de respondenten met de begeleiding naar een succesvolle integratie en de relatie met hun kansperceptie. De individuele beleving van de respondenten met de begeleiding staat in onderzoek 2 centraal.

Onderzoek 3 is een correlationeel en kwantitatief onderzoek waarin de mate van psychopathologische klachten van de respondenten is onderzocht. Daarbij is specifiek gekeken of de hoge mate van algemene psychopathologische klachten verklaard zou kunnen worden uit het vaak voorkomen van posttraumatische stressklachten. Verder werd onderzocht of er verschillen bestaan tussen de twee groepen van respondenten: een groep met een permanente verblijfsvergunning en een tweede groep met een tijdelijke verblijfsvergunning.

De belangrijkste conclusies van dit proefschrift luiden als volgt:

De drie begeleidingsvariabelen vertrouwen, inspraak en rechtvaardigheid hebben een hoge correlatie met de kansperceptie op succesvolle integratie. Tevredenheid met de begeleiding beïnvloedt de perceptie van kansen in positieve zin. We kunnen dus concluderen dat begeleiding die deze drie aspecten optimaliseert, een positief effect zou moeten hebben op de verwachting succesvol te kunnen integreren. Hoewel we theoretisch kunnen verwachten dat positieve verwachtingen ook een effect zullen hebben op integratiegedrag en daarmee op de daadwerkelijke integratie, is verder onderzoek nodig om 
dit aan te tonen. Verder wordt duidelijk dat asielzoekers minder kansen waarnemen om te kunnen integreren dan (ex-)vluchtelingen. Uit de resultaten blijkt dat leeftijd de enige variabele is met een modererend effect op de relatie tussen tevredenheid over begeleiding en de kansperceptie van de respondenten. Bij jongere respondenten er een groter effect is van tevredenheid over integratie op kansperceptie dan bij oudere respondenten. Dit kan erop wijzen dat er in de begeleiding speciale aandacht aan de integratiemogelijkheden van jongeren besteed moet worden. Hoewel er geen andere variabelen werden gevonden die de relatie tussen tevredenheid over de begeleiding en kansperceptie beïnvloedden, waren er wel rechtstreekse verbanden. Psychopathologie heeft bijvoorbeeld een negatieve relatie met kansperceptie: hoe meer psychopathologie, hoe lager de kansen worden ingeschat.

Uit de kwalitatieve studie 2 blijkt dat de respondenten de drie begeleidingsvariabelen belangrijke aspecten van begeleiding vinden. De belangrijkste bevinding van deze studie is wellicht dat de informele begeleiding door zoveel respondenten als veel waardevoller wordt beoordeeld dan de formele begeleiding. Dit roept de vraag op of de formele begeleiding verbeterd kan worden, daarbij gebruikmakend van wat de respondenten zo waarderen aan informele begeleiding (bijvoorbeeld gelijkwaardigheid, benadrukken van hun sterke kanten); of dat dit veroorzaakt wordt door inherente kenmerken van formele begeleiding. In dat laatste geval zou wellicht het hele formele begeleidingssysteem beter vervangen kunnen worden door een informeel systeem.

Uit de resultaten van de eerste twee studies blijkt dat respondenten die geneigd zijn meer actieve coping toe te passen, meer kansen percipiëren om succesvol te kunnen integreren. Dit kan betekenen dat het toepassen van actieve coping in de praktijk een belangrijke werking heeft, zoals het meer contacten leggen en onderhouden met de Nederlandse instanties en bevolking. Hierdoor zullen respondenten zich waarschijnlijk ook competenter gaan voelen en positieve reacties ontvangen. Vervolgens zullen ze hun kansen positiever gaan inschatten.

Tevens blijkt uit de analyses dat passieve coping significant met PTSS en psychopathologie in het algemeen correleert. Dit zou erop kunnen wijzen dat passieve coping de gevoelens van machteloosheid en kwetsbaarheid verder versterkt. Omgekeerd kan psychopathologie het gebruik van passieve coping versterken. Er is dan sprake van een vicieuze cirkel waardoor psychopathologie verder versterkt wordt.

Voor de praktijk van de begeleiding is dit een aanwijzing dat men meer aandacht dient te besteden aan het bevorderen van actieve coping door bijvoorbeeld actievere tijdbesteding gedurende de asielprocedure, het leren van de Nederlandse taal en het inschakelen van hulp, en begeleiding bij de aankomst in Nederland. Dit neemt niet weg dat de onzekerheid over een verblijfsvergunning waarschijnlijk een van de belangrijkste ziekmakende factoren blijft. Het roept de vraag op hoeveel invloed men in de praktijk kan uitoefenen op het verminderen van psychopathologieklachten zolang deze onzekerheid blijft.

Uit de resultaten van onderzoek 2 kunnen we concluderen dat respondenten een affectieve en persoonlijke manier van begeleiding zeer waarderen. Dit betekent dat een 
begeleider die zich niet zakelijk en afstandelijk opstelt, maar emotioneel betrokken, en die interesse toont voor de culturele achtergrond en de behoeften van de respondent, beter in staat is om een gevoel van veiligheid teweeg te brengen, wat weer de verwachtingen van succesvolle integratie versterkt. We concluderen dat een veilige en persoonlijke manier van begeleiden veilige hechtingsmogelijkheden biedt, wat blijkbaar belangrijk is voor een goed begeleidingsresultaat. Een dergelijke veiligheid bieden kan in de praktijk een moeilijke kwestie zijn, omdat er sprake is van interactie tussen twee partijen met hun eigen hechtingstijl. De verwachting is dat een begeleider die veilig gehecht is, ook beter in staat is om te communiceren met cliënten met een problematische voorgeschiedenis, en een veiliger hechting kan bieden.

De bevindingen van onderzoek 3 tonen aan dat alle respondenten inderdaad veel psychopathologische klachten hebben. Vooral de mate van depressie en angstklachten van alle respondenten was hoog. De mate van PTSS-klachten van de respondenten was niet hoog genoeg om te kunnen concluderen dat ze voldoen aan de diagnose van PTSS, en maakte het onwaarschijnlijk dat de hoge mate van algemene psychopathologie voortkwam uit PTSS-klachten. Langdurige stress tijdens de asielaanvraagprocedure en acculturisatiestress lijken betere verklaringen te zijn voor de hoge mate van psychopathologie. 



\section{Literatuurlijst}

Ai, A.L., Peterson, C., \& Ubelhor, D. (2002). War-related trauma and symptoms of post traumatic stress disorder among adult Kosovar refugees. Journal of Traumatic Stress, 15, 157-160.

Ai, A.L., Tice, T.N., Whitsett, D.D., Ishisaka, T., \& Chim, M. (2007). Post traumatic symptoms and growth of Kosovar war refugees: the influence of hope and cognitive coping. The Journal of Positive Psychology, 2 , 55-65.

Ainsworth, M.D., \& Bowlby, J. (1954). Research strategy in the study of mother-child separation. Courr. Cent. Int. Enf., 4, 105.

Ajduković, M., \& Ajduković, D. (1993). Psychological well-being of refugee children. Child-Abuse and Neglect, $17(6), 843-850$.

Allodi, F.A. (1991). Assessment and treatment of torture victims: a critical review. The Journal of Nervous and Mental Disease, 179, 4-11.

Almqvist, K., \& Hwang, P.H. (1999). Iranian refugees in Sweden: Coping processes in children and their families. Journal of Child Research, 6 (2), 167-188.

Al-Saffar, S., Borga, P., Edman, G., \& Hallstrom, T. (2003). The etiology of post traumatic stress disorder in four ethnic groups in out-patient psychiatry. Social Psychiatry, Psychiatric Epidemiology, 38, 456-462.

American Psychiatric Association. (2004). DSM-IV. Diagnostic and Statistical Manual of Mental Disorders, $4^{\text {th }}$ edition (DSM-IV). Washington, DC: APA.

Ang, W. (2007). Workshop: Transculturele ervaring bij het werken met vluchtelingen: omgaan met trauma. Studiedag 'Begeleiding op Vreemde maat'. 22 november 2007.

Arcia, E., Skinner, M., Bailey, D., \& Correa, V. (2001). Models of acculturation and health behaviours among Latino immigrants to the US. Social Science and Medicine, 53, 41-53.

Arends-Tóth, J.V., \& Vijver, F. van de. (2003). Multiculturalism and acculturation: views of Dutch and Turkish-Dutch. European Journal of Psychology, 33, 249-266.

Arrindell, W.A., \& Ettema, J.H.M. (1986). SCL: Handleiding bij een multidimensionele psychopathologie-indicator. Lisse: Swets, testpublisher.

Ataca, B., \& Berry, J.W. (2002). Psychological, sociocultural and material adaptation of Turkish immigrant couples in Canada. International Journal of Psychology, 37, 13-26.

Azghari, Y. (2005). Cultuurbepaalde communicatie. Waarden en belangen van passieve en actieve culturen. Soest: Uitgeverij Nelissen.

Aziz, N. (1999). Cultural sensitization and clinical guidelines for mental health professionals working with immigrant/refugee women in the United States. Dissertation Abstracts International: section B. The Science \& Engineering, 60 (3-B). p. 1239.

Baarda, D.B., Goede, M.P.M. de, \& Teunissen, J. (2001). Basisboek kwalitatief onderzoek. Praktische handleiding voor het opzetten en uitvoeren van kwalitatief onderzoek. Groningen: Wolters-Noordhoff.

Baker, R. (1992). Psychosocial consequences for tortured refugees seeking asylum and refugee status in Europe. New York, NY, US: Cambridge University Press.

Bakker, A.B., Schufeli, W.B., Sixma, H.J., Bosveld, W., \& Dierendonck, D. van. (2000). Patient demand, lack of reciprocity and burnout: A five year longitudinal study among general practitioners. Journal of Managerial Psychology, 16 (34-4), 268-280.

Bala, J. (1995). The interactive context of stress, adjustment and support refugee families and children. In M. Balledux, \& J. de Mare (Red.), Ouder en kindzorg voor migranten en vluchtelingen. Assen: Van Gorcum. 
Bala, J., Dijk, R. van, Kramer, S., \& Ory, F. (2003). Making sense of experience: patronen van betekenisgeving en coping van asielzoekers. Utrechtse School voor Bestuurs- en Organisatiewetenschap. Utrecht.

Bargai, N., Ben-Shakhar, G., \& Shalev, A.Y. (2007). Post traumatic stress disorder and depression in battered women: the mediating role of learned helplessness. Journal of Family Violence, 22, 267-275.

Barnes, D.M. (2001). Mental health screening in the refugee population. Journal of Immigrant Health, 3 (3), 141-149.

Baron, R.M., \& Kenny, D.A. (1986). The moderator-mediator variable distinction in social psychological research-conceptual, strategic, and statistical considerations. Journal of Personality and Social Psychology, 51 (6), 1173-1182.

Basoglu, M., Kilic, S., Salcioglu, E., \& Livanou, M. (2004). Prevalence of posttraumatic stress disorder and comorbid depression in earthquake survivors in Turkey: an epidemiological study. Journal of Traumatic Stress, 17, 133-141.

Bauer, M., \& Priebe, S. (1994). Psychopathology and long-term adjustment after crisis in refugees from East Germany. The International of Social Psychiatry, 40 (3), 165-176.

Bean, T., Eurelings-Bontekoe, E., Mooijaart, A., \& Spinhoven, P. (2006). Factors associated with mental health service need and utilization among unaccompanied refugee adolescents. Administration and Policy in Mental Health, 33 (3), 342-355.

Bean, T.M., Derluyn, I., Eurelings-Bontekoe, E., Broekaert, E., \& Spinhoven, P. (2007a). Comparing psychological distress, traumatic stress reaction, and experiences of unaccompanied refugee minors accompanied by parents. The Journal of Nervous and Mental Disease, 195, 288-297.

Beck, A.T., Rush, A.J., Shaw, B.F., \& Emery, G. (1979). Cognitive therapy of depression. New York: Wiley.

Beek, S. van. (1999). Rechtvaardigheid en vertrouwen, een onderzoek naar de invloed van vertrouwen in de autoriteit op rechtvaardigheidsoordelen. Doctoraal onderzoek. Vakgroep Sociale en Organisatie Psychologie. Universiteit Utrecht.

Beijaard, D., \& Verloop, N. (1996). Assessing teachers' practical knowledge. Studies in Educational Evaluation, 22, 275-286.

Beiser, M., \& Hyman, I. (1997). Time perspective and mental health. American Journal of Psychiatry, 154 (7), 996-1002.

Beiser, M.A., \& Hyman, I. (1997). Refugee, time, perspective and mental health. American Journal of Psychiatry, 154 (7), 996-1002.

Benotsch, E.G., Brailey, K., Vasterling, J.J., Uddo, M., Constans, J.I., \& Sutker, P.B. (2000). War zone stress, personal and environmental resources, and PTSD symptoms in Gulf war veterans: a longitudinal perspective. Journal of Abnormal Psychology, 109, 205-213.

Berg, H. van den, Denolf, L., \& Veer, K. van der. (1997). Het kleine verschil: slaag- en faalfactoren bij trajectbemiddeling van allochtonen. Stichting voor Culturele Studies. Amsterdam: J. Mets.

Bermasco, W. (1999). Vertrouwen en samenwerking in duurzame relaties. Facta, 2, 10-13.

Bernal, G. (1982). Cuban families. In M. Mac-Goldrick, J.K. Pearce, \& J. Giordano (Eds.), Ethnicity and family therapy (pp. 187-207). New York: Guilford Press.

Berry, J.W. (1976). Human ecology and cognitive style: Comparative studies in cultural and psychological adaptation. New York: Sage/Halsted.

Berry, J.W. (1980). Acculturation as varieties of adaptation in: Acculturation, theory, models and some new finding. AAAS selected symposium 39 (Ed.): Amodom. Padilla (pp. 9-25). Boulder, Colorado: Westview Press.

Berry, J.W. (1992). Acculturation and adaptation in a new society. In International Migration. Special Issue. Migration and Health in the 1990s. 30, 69-85.

Berry, J.W. (1997). Immigration, acculturation and adaptation. Applied Psychology: An International Review, 46, 5-68.

Berry, J.W. (2001). A psychology of immigration. Journal of Social Issues, 57, 615-631.

Berry, J.W. (2005). Acculturation: Living successfully in two cultures. International of Intercultural Relations, 29, 697-712.

Berry, J.W., Kim, U., Minde, T., \& Mok, D. (1987). Studies of acculturative stress. International Migration Review, 21, 491-511. 
Berry, J.W., Poortinga, Y.H., Segall, M.H., \& Dasen, P.R. (1992). Cross-Cultural Psychology: Research and Applications. Cambridge: Cambridge University Press.

Besjes, K., Bulder, B., \& Kriek, F. (1998). Monitor kleine groepen. Integratiebeleid minderheden. Een onderzoek. Research voor beleid. Leiden.

Bhugra, D. (2004). Migration and mental health. Acta Psychiatrica Scandinavia, 109, 243-258.

Bies, R.J., \& Moag, J.S. (1986). Interactional justice: communication criteria for fairness. In B. Sheppard (Ed.), Research on negotiation in organizations. Vol 1 (pp. 43-55). Greenwich CT: JAI.

Birman, D., \& Trickett, E.J. (2001). Cultural transitions in first-generation immigrants: acculturation of Soviet Jewish refugee adolescents and parents. Journal of Cross-Cultural Psychology, 32, 456-477.

Birman, D., Trickett, E.J., \& Vinokurv. A. (2002). Acculturation and adaptation of Soviet Jewish refugees adolescents. Predictors of adjustment life domains. American Journal of Community Psychology, 30, 582-607.

Blair, R.G. (2000). Risk factors associated with PTSD and major depression among Cambodian refugees in Utah. Health and Social Work, 25 (1), 23-30.

Blanchard, E.B., Hickling, E.J., Malta, L.S., Jaccard, J., Devineni, T., Veazey, C.H., \& Galovski, T.E. (2003). Prediction of response to psychological treatment among motor vehicle accident survivors with PTSD. Behavior Therapy. 34, 351-363.

Bliatout, B.T., Bliatout, H.Y., \& Lee, D.T.T. (1985). Mental health and prevention activities targeted to Southeast Asian mental health: treatment, prevention, services, training and research. Washington DC: Department of Health and Human Service.

Bontempo, R., \& Rivero, J.C. (1992). Cultural variation in cognition: the role of self-concept in the attitude, behavior. Paper presented at the meeting of the American Academy of Management. Las Vegas. NV.

Boomkamp, M.E. (2008). Trauma's, sociale steun en copingstijl als voorspellers van posttraumatische stress. Master thesis. Utrecht: Universiteit Utrecht.

Boomstra, R., \& Kramer, S. (1997). Cultuurverschillen in de interacties tussen hulpverleners en vluchtelingen. Utrecht: Universiteit Utrecht.

Boon, S.D., \& Holmes, J.G. (1991). The dynamics of interpersonal trust: resolving uncertainty in the face of risk. In R.A. Hinde, \& J. Grobel (Eds.), Cooperation and prosocial behavior (pp. 190-211). Cambridge, England: Cambridge University Press.

Bos, K. van den. (1996). De rechtvaardigheid van procedures en de eerste aanzetten tot een nieuwe rechtvaardigheidstheorie. Nederlands Tijdschrift voor de Psychologie, 5, 183-191.

Bos, K. van den. (2001). Uncertainty management: the influence of uncertainty salience on reactions to perceived procedural fairness. Journal of Personality and Social Psychology, 80, 931-941.

Bos, K. van den. (2002). Wat is eerlijk: de sociale psychologie van waargenomen rechtvaardigheid. De Psycholoog, 3, 177-182.

Bos, K. van den. (2005). What is responsible for the fair process effect? In J. Greenberg, \& J.A. Colquilt (Red.), Handbook of organizational justice: Fundamental questions about fairness in the workplace (pp. 273-300). Mahwal, NJ: Erlbaum.

Bos, K. van den. (2007). Hot cognition and social justice judgments: the combined influence of cognitive and affective factors on the justice judgment process. In D. De Cremer (Red.), Advances in the Psychology of Justice and Affect (pp. 59-82). Greenwich, CT: Information Age Publishing.

Bos, K. van den, Lind, L.E., Vermunt, R., \& Wilke, H.A.M. (1997). How do I judge my outcome when I do not know the outcome of others? The psychology of the fair process effect. Journal of Personality and Social Psychology. 72, 1034-1046.

Bos, K. van den, Wilke, H.A.M., \& Lind, E.A. (1998). When do we need procedural fairness? The role of trust in authority. Journal of Personality and Social Psychology, 75, 1449-1458.

Bos, K. van den, Bruins, J., Wilke, H.A.M., \& Dronkert, E. (1999). Sometimes unfair procedures have nice aspects: on the psychology of fair process effects. Journal of Personality and Social psychology, 77 (2), 324-336.

Bourhis, R.Y., Moïse, L.C., Perreault, S., \& Senégal, S. (1997a). Toward an interactive acculturation model: a social psychological approach. International Journal of Psychology, 36 (6), 369-389. 
Bouwman, T.K, Luteijn, F., Albersnagel, F.A., \& Ploeg, F.A.E. van der. (1985). Enige ervaring met de Beck Depression Inventory (BDI). Gedragstherapie, 13, 13-24.

Bovenkerk, F. (1978). Omdat zij anders zijn: Patronen van rasdiscriminatie in Nederland. Meppel: Boom Uitgeverij.

Bowlby, J. (1969). Attachment and loss. Attachment (1). New York: Basic Books.

Boyd, M.A. (1998). Psychiatric Nursing: Contemporary Practice. Philadelphia: Lippincott.

Brassé, P., \& Schelven, W. van. (1980). Assimilatie van vooroorlogse immigranten: drie generaties Polen, Slovenen, Italianen in Heerlen. Den Haag: Staatsuitgeverij.

Braster, J.F.A. (2000). De kern van casestudy's. Assen: Van Gorcum.

Brennan, B., \& Tamara, S. (1996). Stress and social support among dispersed refugees from Guatemala: Toward the creation of a community-based intervention for survivors of political repression. The Science-and-Engineering, 57 (1-B): 0691.

Breslau, N., Neria, Y., \& Bromet, E.J. (2000). Comorbidity of PTSD and depression: linked or separate incident? Society of Biological Psychiatry, 48, 878-880.

Brewer, M., \& Campbell, D.T. (1976). Ethnocentrism and intergroup attitudes: East African evidence. New York: Halstead/Wiley.

Brewin, C.R., Andrews, B., \& Valentine, J.D. (2000). Meta-analysis of risk factors for posttraumatic stress disorder in trauma-exposed adults. Journal of Consulting and Clinical Psychology, 68, 748-766.

Brink, M. (1997). Waar een wil is, is een weg? De moeizame integratie van vluchtelingen uit Iran, Somalië en voormalig Joegoslavië. Amsterdam: Faculteit Ruimtelijke Wetenschappen. UNI.

Brink, M., Pasariboe, M., \& Hollands, M. (1996). Integratie van vluchtelingen op de arbeidsmarkt: resultaten van een vervolgonderzoek onder statushouders afkomstig uit Iran, Somalië en voormalig Joegoslavië. Amsterdam: Sociaal-Geografische Studies. UAF.

Bruce, M.L., Takeuchi, D.T., \& Leaf, P.J. (1991). Poverty and psychiatric status; longitudinal evidence from the New Haven. Epidemiologic area study. Archives of General Psychiatry, 48, 470-474.

Budding, P. (1998). Inburgering en beleving van vluchtelingen in de provincie Utrecht: de ervaring en beleving van vluchtelingen en zorgverleners in de provincie Utrecht. Utrecht: Multicultureel Instituut.

Buijs, F.J., \& Nelissen, C. (1994). Tussen continuïteit en verandering: Marokkanen in Nederland (Between continuity and change: Moroccans in the Netherlands. In H.J. Vermeulen, \& R. Penninx (Eds.), Het democratische ongeduld: de emancipatie van zes doelgroepen van het minderhedenbeleid (pp. 177-206). Amsterdam: Het Spinhuis.

Buuren, J.A. van, Hutjes, J., \& Giesbertz, W. (1990). De kwaliteit van het onderzoeksontwerp. In Kwalitatief onderzoek. De gevalsstudie als onderzoeksstrategie, deel 1, opzet en dataverzameling, hoofdstuk 3 (pp. 58-87). Heerlen: Open Universiteit.

Byrne, D. (1971). The attraction paradigm. New York: Academic Press.

Can, M., \& Voordouw, I. (2001). Handleiding voor de cursus 'Lichte dagen, donkere dagen'. Utrecht: Trimbos Instituut.

Cappeliez, P.H., Flynn, R.J. (1993). Depression and social environment. Research and intervention with neglected population. London: Mc Gill-Queen's: University Press. Montreal \& Kingston.

Carlson, E.B. (2002). Challenges to assessing traumatic stress histories in complex trauma survivors, paper presented at the Annual Meeting of the International Society for Traumatic Stress Studies. Baltimore, MD.

Carlson, E.B., Rosser-Hogan, R. (1991). Trauma experiences post traumatic stress, dissociation and depression in Cambodian refugees. American Journal of Psychiatry, 148, 1548-1551.

Carlsson J.M., Rolf Olsen, D., Mortensen E.L., \& Kastrup, M. (2006). Mental health and health-related quality of life: 10 year follow-up of tortured refugees, The Journal of Nervous and Mental Disease, 194 (10), 725 731.

Carver, C.S., Scheier, M.F., \& Weintraub, J. (1989). Assessing coping strategies: A theoretically based approach. Journal of Personality and Social Psychology, 56, 267-283.

CBS. (2004). Bevolkingstrends 2004, Centraal Bureau voor de Statistiek. Voorburg. p. 45. 
CBS. (2008). Bevolkingstrends, 1e kwartaal 2008. Centraal Bureau voor de Statistiek. Voorburg.

CBS. (2009). Bevolkingstrends, 1e kwartaal 2009. Centraal Bureau voor de Statistiek. Voorburg.

CBS. (2010). Bevolkingstrends, 1e kwartaal 2010. Centraal Bureau voor de Statistiek. Voorburg.

CBS. (2011). Bevolkingstrends, 1e kwartaal 2011. Centraal Bureau voor de Statistiek. Voorburg.

Chan Won Shing, R. (2001). The effects of distal traumas on posttraumatic stress disorders and co-morbid psychopathology. Dissertation-Abstract-International Section. The Sciences and Engineering, 61 (8-B): 4395.

Chavoushi, M. (1996). Kritische integratie in de praktijk. Afstudeeropdracht. Hogeschool Rotterdam \& Omstreken. Faculteit WAG.

Choi, J.W., Miller, A., \& Wilbur, J.E. (2009). Acculturation and depressive symptoms in Korean immigrant women. Journal of Immigrant and Minority Health 11 (1), 13-19.

Coenen, H.M.J. (1987). Handelingsonderzoek als exemplarisch leren. Groningen: Konstapel.

Coenen-Hanegraaf, M., Valkenburg, B., Ploeg, M., \& Coenen, H.M.J. (2000). Begeleid werken: theorie en methodiek van een individuele, vraaggerichte benadering. Utrecht: Jan van Arkel.

Cohen, J., \& Cohen, P. (1983). Applied multiple regression/correlation analysis for the behavioral sciences (2e druk). Hillsdale, New Jersey: Lawrence Erlbaum Associates Publishers.

Cohen, R.L. (1988). Fabrications of Justice. Paper presented at the International conference on Social Justice and Social Problems. The Netherlands: The University of Leiden.

Compton, W.C. (2005). Introduction to positive psychology. Belmonth, Wadworth.

Cornelis, B., Dallinga, A., \& Voeten, H. (1997). Inburgering aan den lijve. Een onderzoek naar ervaringen van vluchtelingen met het inburgeringsbeleid. VON en Vluchtelingen Werk Nederland. Amsterdam.

Coutts, A., Ramos-Pinto, P., Cave, B., \& Kawachi, I. (2007). Social capital indicators in UK. Londen: Commission for Racial Equality.

Cronbach, L. (1971). Test validation. In R.L. Thorndike (Ed.), Educational measurement. Washington D.C. American Council on Education. Hiatry.

Cuijpers, P., Straten, A. van, Warmerdam, L., \& Andersson, G. (2008). Psychological treatment of depression: a meta-analytic database of randomized studies. BioMed Central Psychiatry, 8 (1), 36.

D'Avanzo, C.E., Frye, B., \& Froman, R. (1994). Culture, stress, and substance use in Cambodian refugee women. Journal of Studies on Alcohol, 55 (4), 420-426.

Dagevos, J. (2001). Perspectief op integratie. Over de sociaal-culturele en structurele integratie van etnische minderheden in Nederland. WRR. Werkdocument, W121, Den Haag.

Dagevos, J. (2008). Informatievoorziening integratie niet-westerse allochtonen: inventarisatie van de beschikbare bronnen en voorstellen voor verbetering. In J. Dagevos, \& M. Gijsberts, Sociaal en Cultureel Planbureau (SCP). $50 \mathrm{p}$.

Dawson, E.J., Crano, W.D., \& Burgoon, M. (1996). Refining the meaning and measurement of acculturation: Revisiting a novel methodological approach. Intercultural Rel, 1, 97-114.

Deutsch, M. (1975). Equity, equality and needs: what determines, which value, will be used for distributive justice? Journal of Social Issues, 31, 137-150.

Devillé, W., Uiters, E., Westert, G.P., \& Groenewegen, P. (2006). Perceived health and consultation of Gps among ethnic minorities compared to the general population in the Netherlands. In G.P. Westert, L. Jabaaij, \& F.G. Schellevis (Eds.), Morbidity performance and quality in primary care. Dutch General Practice on Stage (pp. 85-96). Oxford: Radcliffe.

Dijk, R. van, Bala J., Öry F., Kramer S. (2001). Now we have lost everything: Asylum seekers in the Netherlands and their experience with health care. Medische Antropologie, 13 (2), 284-299.

Dijk, J.A.G.M. van, Goede, M.P.M. de, Hart, H, 't., \& Teunissen, J. (1991). Onderzoeken en veranderen: methoden van praktijkonderzoek. Leiden/Antwerpen: Stenfert Kroese.

Dijk, R. van. (1995). Cultuur en trauma. Culturele variabelen in de omgang met schokkende gebeurtenissen. Medische Antropologie, 7 (1), 128-142.

Domínguez, S., \& Maya-Jariego, I. (2008). Acculturation of host individuals: immigrants and personal networks. American Journal of Community Psychology, 43 (3), 309-327. 
Domino, G., \& Acosta, A. (1987). The relation of acculturation and values in Mexican Hispanic. Journal of Behavioral Sciences, 9, 131-150.

Doosje, B., Spears, R., \& Koomen, W. (1996). Cognitieve en motivationele aspecten van stereotypering. Nederlands Tijdschrift voor de Psychologie, 51, 211-218.

Dovidio, J.F., Gaertner, S.L., \& Validzic, A. (1998). Intergroup bias, status, differentiation and common intergroup identity. Journal of Personality and Social Psychology. 75, 109-120.

Drenth, P.J.D., \& Stijsma, K. (1990). Testtheorie: inleiding in the theorie van psychologische test en zijn toepassingen. Houten: Bohn Stafleu van Loghum.

Dupont, H.B., Kaplan, C., Verbraek, H., Braam, R., \& Wijngaart, G. van de. (2005). Killing time: drug and alcohol problems among asylum seekers in the Netherlands. International Journal of Drug Policy, 16, $27-36$.

Dyer, W.G., Jr., \& Wilkins, A.L. (1991). Better stories, not better construct, to generate better theory: a rejoinder to Eisenhardt. Academy of management Review, 16 (3), 613-619.

Early, P.C., \& Lind, E.A. (1987). Procedural justice and participation in task selection: the role of control in mediating justice judgments. Journal of Personality and Social Psychology, 5, 1158-1160.

Elbaz, M., \& Helly, D. (2000). Mondialisation, citoyenneté et multiculturalisme. Les Presses de l'université Laval: L'Harmattan.

Elchardus, M. (1998). Wantrouwen en behagen. VUBPers, 37-76.

Elk, J. van. (2005). Communicatiewijzer allochtonen. Den Haag: SDU.

Ellemers, J.E., \& Vaillant, R.E.F. (1985). Indische Nederlanders en gerepatrieerden. Muiderberg: Coutinho.

Emans, B. (1990). Interviewen, theorie, techniek en training. Groningen: Wolters-Noordhoff, 2e druk.

Engbersen, G., \& Gabriëls, R. (Red.). (1995). Sferen van integratie: naar een gedifferentieerd allochtonenbeleid. Amsterdam/Meppel: Boom.

Engelhard, I.M., Arntz, A., \& Hout, M.A. van den. (2007). Low specificity of symptoms on the post-traumatic stress disorder symptom scale. British Journal of Clinical Psychology, 46, 449-456.

Entzinger, H.B., \& Biezeveld, R.L. (2003). Benchmarking in immigrant integration. Report to the European Commission. Rotterdam: Erasmus Universiteit/ERCOMER.

Erdogan, B., Kraimer, M.L., \& Liden, R.C. (2001). Procedural justice as a two-dimensional construct: An examination in the performance appraisal account. Applied-Behavioral-Science, 37 (2), 205-222.

Evers, A., Vliet-Mulder, J.C. van, \& Groot, C.J. (2000). Documentatie van tests en testresearch in Nederland. Assen: Gorcum \& Comp.

Eyken, N. van. (2005). Vluchtelingen bij de psychiater. In Goede praktijkvoorbeelden uit de hulpverlening aan vluchtelingen. Gent: Tanghe Printing.

Eyou, M.L., Adair, V., \& Dixon, R. (2000). Cultural identity and psychological adjustment of adolescent Chinese immigrants in New Zealand. Journal of Adolescence, 23, 531-543.

Falicov, G.J. (1982). Mexican families. In M. Mac-Goldrick, J.K. Pearce, \& J. Giordan (Eds.), Ethnicity and Family therapy. (pp. 134-163). New York: Guilford Press.

Fazel, M., Wheeler, J., \& Danesh, J. (2005). Prevalence of serious mental disorder in 7000 refugees resettled in Western countries: a systematic review. The Lancet, 365, 1309-1314.

Feeny, N.C., Zoellner, L.A., Fitzgibbons, L.A., \& Foa, E.B. (2000). Exploring the roles of emotional numbing, depression and dissociation in PTSD. Journal of Traumatic Stress, 13, 489-498.

Feijter, C. de. (2008). Interculturalisatie is geen vrijblijvend onderwerp meer: meer kennis en aandacht nodig voor achtergrond allochtone patiënten. Huisartsen en Praktijk, 19 (4), 48-49.

Feldmann, C.T. (2007). Verder leven na de vlucht. Is de huisarts een bondgenoot? Cultuur Migratie Gezondheid 4 (7), 194-205.

Feldmann, C.T., Bensing, J.M., Ruijter, A. (2007). Worries are the mother of many diseases: general practitions and refugees in the Netherlands on stress, being ill and prejudice. Patient Education and Counseling, 65 (3), 369-380.

Ferguson, E., \& Cox, T. (1991).The nature of primary appraisal. British Journal of Psychology (submitted). 
Festinger, L. (1957). A theory of social comparison processes. Human Relations, 7, 117-140.

Flynn, R.J. (1993). Depression and the social environment: research and intervention with neglected population. Canada: MacGill-Queens, University Press.

Foa, E.B., Cashman, L., Jaycox, L., Perry, K., \& American Psychiatric Association. (1997). The validation of a self-report measure of posttraumatic stress disorder: the Posttraumatic Diagnostic Scale. Psychological Assessment, 9, 445-451.

Foa, E.B., Riggs, D.S., Dancu, C.V., \& Rothbaum, B.O. (1993). Reliability and validity of a brief instrument for assessing Post Traumatic Stress Disorder. Journal of Traumatic Stress, 6, 459-473.

Folger, R. (1977). Distributive and procedural justice: combined impact of 'voice' and improvement of experienced in equity. Journal of Personality and Social Psychology, 35, 108-119.

Folkman, S., \& Lazarus, R.S. (1980). An analysis of coping in a middle age community sample. Journal of Health and Social Behavior, 21, 219-239.

Folkman, S., \& Moskowitz, J.T. (2004). Coping: pitfalls and promise. Annual Reviews of Psychology, 55, 745774.

Frye, B., \& D'Avanzo, C.D. (1994). Cultural themes in family stress and violence among Cambodian refugee women in the inner city. Advance in Nursing-Science, 16 (3), 64-77.

Gaertner, S.L., \& Dovidio, J.F. (2000). Reducing intergroup bias. Psychology Press: Hove.

Garber, J., \& Seligman, M.E.P. (1980). Human helplessness: theory and applications. New York Press.

Garza, R.T., \& Gallegos, P.I. (1985). Environmental influences and personal choice: A humanistic perspective on acculturation. Hispanic Journal of Behavioral Sciences, 7, 365-379.

Gernaat, H.B.P.E., Malwand, A.D., Laban, C.J., Komproe, I., \& Jong, J.T.V.M. de. (2002). Veel psychologische stoornissen bij Afghaanse vluchtelingen met verblijfsstatus in Drenthe, met name depressieve en posttraumatische stressstoornis. Nederlands Tijdschrift voor Geneeskunde, 146, 127-131.

Gerritsen A.A.M, Ploeg, H.M. van der, Devillé W., Lamkaddem, M. (2005). 'Gevlucht - Gezond?' Een onderzoek naar de gezondheid van, en het zorggebruik door asielzoekers en vluchtelingen in Nederland. Utrecht: Nivel, VU medisch centrum.

Gerritsen, A.A.M., Bramsen, l., Devillé, W., Willigen, L.H.M. van, Hoems, J.E., \& Ploeg, H.M. van der. (2006). Physical and mental health of Afghan, Iranian en Somali asylum seekers and refugees living in the Netherlands. Social psychiatry Psychiatric Epidemiology, 41, 18-26.

Gerritsen, A.A.M., Ploeg, H.M. van der, Devillé, W., \& Lamkaddem, M. (2007). Het onderzoek 'Gevlucht-Gezond?' vanuit preventieperspectief; epidemiologische gegevens over de gezondheidstoestand en het zorggebruik van asielzoekers. Utrecht: Landelijke Service Bureau MOA van GGD Nederland.

Ghorashi, H. (2006). Ik ben veilig maar niet gelukkig: de impact van de verzorgingsstaat op het leven van vluchtelingen. Tijdschrift voor cultuur, management en organisatie, 71 (3/4), 73-85.

Gijsberts, M., \& Dagevos, J. (2004). Concentratie en wederzijdse beeldvorming tussen allochtonen en autochtonen. Migratiestudies, 3, 145-168.

Gijsberts, M., \& Dagevos, J. (Red.). (2009). Jaarrapport integratie 2008, Den Haag: Sociaal en Cultureel Planbureau.

Gijsberts, M., \& Dagevos, J. (Red.). (2010). Jaarrapport integratie 2009. Den Haag: Sociaal en Cultureel Planbureau.

Gijsberts, M., \& Dagevos, J. (Red.). (2011). Jaarrapport integratie 2010. Den Haag: Sociaal en Cultureel Planbureau.

Gijsberts, M., Huijnk, W.,\& Dagevos, J. (Red.). (2012). Jaarrapport integratie 2011. Den Haag: Sociaal en Cultureel bureau.

Gil, S. (2005). Coping style in predicting posttraumatic stress disorder among Israeli students. Anxiety, Stress and coping, 18,351-359.

Gil, S., \& Caspi, Y. (2006). Personality traits, coping style, and perceived threat as predictors of posttraumatic stress disorder after exposure to terrorist attack: A prospective study. Tijdschrift voor Psychiatrie, 41, 341-348. 
Gilson, L. (2001). The role of procedural Justice in the relationship between demographic diversity, dissimilarity, work-related affective outcomes, and creative performance. Human and Social-Sciences, $61(2-A): 2802$.

Ginzburg, K. (2006). Comorbidity of PTSD and depression following myocardial infarction. Journal of Affective Disorders, 94, 135-143.

Goetz, J.P., \& LeCompte, M.D. (1984). Ethnography and qualitative design in educational research. New York: Academic Press.

Gong-Guy, E., Cravens, R.B., \& Patterson, T.E. (1991). Clinical issues in mental health service delivery to refugees. American Psychologist, 46 (6), 642-648.

Good, B.J., Delvecchio-Good, M.J., \& Moradi, R. (1985). The interpretation of Iranian depressive illness and dysphoric affect. In A. Kleinman en B. Good (Eds.), Culture and depression (pp. 369-428). Berkeley and Los Angeles, California: University of California Press.

Goosen, S., Gerritsen, A. (2007). Het onderzoek 'Gevlucht-Gezond?' vanuit preventieperspectief. Epidemiologische gegevens over de gezondheidstoestand en het zorggebruik van asielzoekers. Utrecht: GGD Nederland, literatuurreferenties 85.

Gowricharn, R. (1997). Multiculturele samenleving. Integratiekolder? Over de dynamiek van de multiculturele samenleving. Justitiële verkenningen, 23, 73-82.

Goyani, L., \& Halberstadt, E. (1994). Gevangenen van het verleden: een onderzoek naar psychosociale en somatische klachten onder Albanezen uit Kosovo in Nederland. Utrecht: University Utrecht, Master thesis.

Greenberg, J. (1987). A taxonomy of organizational justice theories. Academy of Management Review, 12, 9-22.

Groot, A.D. de. (1961, 1e druk: 1994, 2e druk). Methodologie. Den Haag: Mouton.

Grumbkow, J. von, \& Ramaekers, E. (2000a). Trajectbegeleiding: faire procedures en kansen op positieverbetering. Tijdschrift voor Welzijnswerk, 24 (229), 23-34.

Grumbkow, J. von, \& Ramaekers, E. (2000b). Vertrouwen: de cruciale factor in trajectbegeleiding. Gids op Maatschappelijk gebied, 91 (9), 30-41.

Grumbkow, J. von, \& Ramaekers, E. (2004). Is trajectbegeleiding een werkzame medicijn voor werklozen met depressieve gevoelens? Tijdschrift voor Welzijnswerk, 28 (262), 30-41.

Gunthert, K.C., Cohen, L.H., Butler, A.C., \& Beck, J.S. (2005). Predictive role of daily coping and affective reactivity in cognitive therapy outcome: Application of a daily process design to psychotherapy research. Behavior Therapy, 36, 77-88.

Haan, A. de, Knipscheer, J., Kleber, R. (2007). Trauma en acculturatie. Bosnische vluchtelingen en de invloed van acculturatie en traumatische stress op de psychische gezondheid. Cultuur, Migratie, Gezondheid 4, 206-217.

Hagendoorn, L., \& Hraba, J. (1989). Foreign different, deviant, seclusive and working class: anchors to an ethnic hierarchy in the Netherlands. Ethnic and Racial Studies, 12, 441-468.

Hagendoorn, L., Veenman, J., \& Vollebergh, W. (2003). Integrating immigrants in the Netherlands. England Ashgate.

Halewijn Staal, B. (1997). Hoogopgeleide vluchtelingen in het Nederlandse arbeidsproces: belemmeringen en mogelijkheden. Onderzoek in opdracht van Vluchtelingen Organisatie Nederland. Universiteit Utrecht.

Hart, H. 't, Dijk, J.A.G.M. van, \& Goede, P.M. de. (1996). Onderzoeksmethode. Amsterdam/Meppel: Boom.

Hart, O.D. (1998). Exploring applicant reactions to selection processes from an organizational justice perspective. The Sciences and Engineering, 59 (2-b), 902.

Helman, C.G. (1990). Mental health status in refugees: an integrative review of current research. Mental Health Nursing, 21, 397-410.

Heptinstall, E., Sethna, V., \& Taylor, E. (2004). PTSD and depression in refugee children: Association with pre-migration trauma and post-migration trauma and post migration stress. European Child \& Adolescent Psychiatry, 13, 373-380.

Hertog, J.F. den. (1991). Gevalsstudies in het organisatieonderzoek. Methodologische Verkenning. No. 4. Maastricht: Merit. 
Hertog, J.F. den, \& Sluijs, E. van. (1995). Onderzoek in organisaties. Een methodologische reisgids. Assen: Van Gorcum.

Hessels, T. (2002). Iraniërs in Nederland, een profiel. Ministerie van Binnenlandse Zaken en Koninkrijksrelaties. Den Haag.

Hofstede, G. (1980). Culture's consequences: International differences in work-related values. Beverly Hills, CA: Sage Publications.

Hofstede, G. (1983). Dimensions of national cultures in fifty countries and three regions. In J.B. Deregowski, S. Dziurawiec et al. (Eds.), Explications in Cross-Cultural Psychology (pp. 335-355). Netherlands: Swets \& Zeitlinger.

Hofstede, G. (1997). Cultures and organizations: software of the mind. New York: McGraw-Hil.

Hofstede, G., \& Bond, M.H. (1984). Cultural dimensions. Journal of Cross-Cultural Psychology, 15, 417-433.

Hofstede, G., \& Hofstede, G.J. (2005a). Allemaal andersdenkenden, omgaan met cultuurverschillen. Amsterdam: Contact.

Hondius, A.J.K., \& Willigen, L.H.M. van. (1992). Empirisch onderzoek naar de klachten van vluchtelingen, Amsterdam: Swets \& Zeitlinger.

Hondius, A.J.K., \& Willigen, L.H.M. van. (1992). Vluchtelingen en Gezondheid. Deel II. Lisse: Swets \& Zeitlinger. Hoofdakker, R.H. van den. (1978). Het klinische begrip depressie. Nederlands Tijdschrift voor de Psychologie, 33, 221-254.

Hooge, J. (1995). Wie neemt deel aan het individueel begeleidingsplan? Psychosociaal profiel en opvolging van de deelnemers. Leuven: Hoger Instituut voor de Arbeid.

Hoogerwerf, H. (2001). De onweerstaanbare gelijkheid: een geschiedenis van het sociaal-politieke denken. Amsterdam: Damon BV. Uitgeverij.

Horebeek, K. van. (2005). Samenwerken met partners: samen kan het beter: de meerwaarde van samenwerking tussen eerste- en tweedelijnshulpverlening. In Goede praktijkvoorbeelden uit de hulpverlening aan vluchtelingen. Gent: Tanghe Printing.

Horowitz, M.J. (1979). Psychological response to serious life events. In V. Hamilton, \& D.M. Warburton (Eds.), Human stress and cognition: an information processing approach. (pp. 235-266).

Horowitz, M.J. (1986). Stress response syndromes (2 $2^{\text {nd }}$. ed.). New York: Jason Aronson.

Houldon, P., Latour, S., Walker, L., \& Thibaut, J. (1978). Preferences for modes of dispute resolution as a function of process and decision control. Journal of Experimental Social Psychology, 14, 13-30.

Hsu, S. (1999). Somatization among Asian refugees and immigrants as a culturally shaped illness behaviour. Academy Medical in Singapore, 28, 841-845.

Huffman, C., \& Cain, L.B. (2001). Adjustment in performance measures: distributive and procedural justice effects on outcome satisfaction. Psychology and Marketing, 18 (5), 283-295.

Huizingh, E. (2006). Handleiding SPSS 14.0 voor Windows. Amsterdam: Meeuwis.

IJzendoorn, M.H. van, \& Miedema, S. (1986). De kwaliteit van kwalitatief onderzoek. Pedagogische Studiën, 63, 498-505.

Jaarrapport integratie. (2004). ISEO/SCP (SPVA-03 gewogen).

Jahanara-Darabi, M. (1997). De integratie van vluchtelingen en de rol van hulpverleners in het proces. Afstudeerscriptie. Ichthus Hogeschool Rotterdam.

Jansen J., Schuit, A.J., Lucht, F. van der. (2002). Tijd voor gezond gedrag; Bevordering van gezond gedrag bij specifieke groepen. Bilthoven: Rijksinstituut voor Volksgezondheid en Milieu (RIVM).

Janssens, F.J.G. (1985). Betrouwbaarheid en validiteit in interpretatief onderzoek. Pedagogisch Tijdschrift, 10, 149-161.

Jasinskaja-Lahti, I., \& Liebkind, K. (2000). Predictors of the cultural degree of acculturation of Russian speaking immigrant adolescents in Finland. International Journal of Intercultural Relations, 24, 503-518.

Jaukov, J. (2002). The forms of victimization in the territory of the former Yugoslavia. European Journal of Crime, Criminal Law and Criminal justice, 10, 109-116. 
Joels, C. (2008). Impact of international policy on the health of people seeking asylum. Nursing standard, 22 (31), 35-40.

Johnson, H., \& Thompson, A. (2007). The development and maintenance of post-traumatic stress disorder (PTSD) in civilian adult survivors of war trauma and torture: A review. Clinical Psychology Review, 28, 36-47.

Johnson, S.M., \& Whiffen, V.E. (2005). Attachment processes in couple and family therapy. New York: Guilford Press.

Jong, J.T.V. de. (1996). Epidemiologie, hulpzoekgedrag en zorgconsumptie. In J.T.V.M. de Jong, \& M. van den Berg (Red.), Transculturele psychiatrie en psychopathologie. Handboek voor hulpverlening en beleid. Lisse: Swets \& Zeitlinger.

Jongh, D. de, \& Ee, M. Van. (2002). Onderzoek naar gezondheidsbeïnvloedende factoren ervaren door asielzoekers in een asielzoekerscentrum. MOA/GGD.

Jongh, D.M. de, Ee, M.J. van, \& Dieleman, M.A. (2004). Leven in een asielzoekerscentrum; asielzoekers aan het woord over hun gezondheid. Tijdschrift voor Gezondheidswetenschappen, 82, 112-117.

Jozefzoon, L.M.E. (1999). Gezondheidservaring van asielzoekers en hun verblijf in het asielzoekerscentrum. Utrecht: NSPH scriptie.

Karregat, S., \& Steensma, H. (2005). Sociale rechtvaardigheid, psychologisch terugtrekgedrag en ziekteverzuim. Gedrag \& Organisatie, 18, 139-155.

Kashima, Y., Siegal, M., Tanaka, K., \& Kashima, E. (1992). Do people believe behaviors are consist with attitudes? Toward a cultural psychology of attribution process. British Journal of Social Psychology, 31, 111-124.

Kawachi, I. (2006). Justice at work and health: caution or correlation? Occupational and Environmental Medicine, 63, 578-580.

Keane, T.M., Marshall, A.D., \& Taft, C.T. (2006). Post traumatic stress disorder, etiology, epidemiology and treatment outcome. Annual Review of Clinical Psychology, 2, 161-197.

Kessler, R.C., Berglund, P., Demler, O. (2003). The epidemiology of major depressive disorder-Results from the National Comorbidity Survey Replication. Journal of the American Medical Association, 289, 30953105.

Keyes, F. (2000). Mental health status in refugees: an integrative review of current research. Mental Health Nursing, 21, 397-410.

Kiesler, D.J. (1983). The interpersonal circle: a taxonomy for the complementarity in human transactions. Psychological Review, 90, 185-214.

Kingma, M. (1999). Preventie en opvang van traumatische ervaringen. Tijdschrift voor verpleegkundigen, 6, 178-182.

Kirk, J., \& Miller, M.L. (1986). Reliability and validity in qualitative research. Beverly Hils/London/New Delhi: Sage.

Klaver, J., Mateman, S., \& Tromp, E. (2005). Vluchtelingen en werk. Integratiebarometer: een onderzoek naar de integratie van vluchtelingen in Nederland. Eindrapport. Amsterdam: Regioplan, Beleidsonderzoek.

Kleber, R.J. (1996). Het begrip posttraumatische stress-stoornis in cross-cultureel perspectief. Mogelijkheden, beperkingen en bedenkingen. Medische Antropologie, 8 (1), 27-43.

Kleber, R.J. (2000). Het trauma voorbij. Over de grenzen van de psychotraumatologie. De Psycholoog, 35 (1), 8-14.

Kleber, R.J., \& Brom, D. (2003). Coping with trauma, theory prevention and treatment, Lisse: Swets \& Zeitlinger.

Kleber, R.J., Figley, C.H.R., \& Cresons, B.P.R. (1995). Beyond trauma: social and cultural dimensions. New York: Plenum.

Kleinpenning, G., \& Hagendoorn, L. (1993). Vormen van racisme en de cumulatieve dimensie van etnische attitudes. Social Psychology Quarterly, 56 (1), 21-36.

Klink, J.J.L. van der, \& Terluin, B. (2005). Psychische problemen en werk. Lisse: Bohn Stafleu van Loghum.

Knippenberg, A. van, \& Siero, F.W. (2000). Multivariate analysis. Derde druk. Houten/Zaventem: Bohn Stafleu van Loghum. 
Knipscheer, J.W., \& Kleber, R.J. (2004a). A need for ethnic similarity in the therapist patient interaction? Mediterranean migrant in Dutch mental health care. Journal of Clinical Psychology, 60, 543-554.

Knipscheer, J.W., \& Kleber, R.J. (2005). Psychotherapie met allochtonen, echt anders. Maandblad Geestelijke Volksgezondheid, 60 (7), 717-724.

Knipscheer, J.W., \& Kleber, R.J. (2005b). Migranten in de GGZ. Empirische bevindingen rond gezondheid, hulpzoekgedrag, hulpbehoeften en waardering van zorg. Tijdschrift voor Psychiatrie, 47 (11), 753-759.

Knipscheer, J.W., \& Kleber, R.J., (1998). Migratie, psychische (on)gezondheid en hulpverlening. De psycholoog, 33 (4), 151-157.

Knipscheer, J.W., Kleber, R.J. (2006). The relative contribution of post-traumatic and acculturative stress to subjective mental health among Bosnian refugees. Journal of Clinical Psychology, 6 (293), 339-353.

Knipscheer, J.W., Kok, H., \& Kleber, R.J. (2004c). Allochtonen in de GGZ: naar een verbetering van kwaliteit van hulpverlening. Utrecht: Universiteit Utrecht.

Komproe, I.H. (2002). PTSD, Angst en depressie bij vluchtelingen in oorlogsgebieden. Transcultural Psychological Organization (TPO). Peace of Mind, Vrije Universiteit Amsterdam.

Korsgaard, M.A., \& Roberson, L. (1995). Procedural justice in performance evaluation: the role of instrumental and non-instrumental voice in performance appraisal discussions. Journal of Management, 21 (4), 657-699.

Koser, K. (1997). Het toelatingsbeleid: ervaring van Iraanse asielzoekers in Nederland. Migrantenstudies, 1, 42-55.

Kraemer, G.W. (1992). A psychological theory of attachment. Behavioral and Brain Sciences, 15, 493-541.

Kramer, R., \& Tyler, T.R. (1996). Trust in organizations: frontiers of theory and research. Thousend Oaks, CA, Cage.

Kramer, S. (2003). Binnen de grenzen van het (on)mogelijke: patroon in betekenisverlening en coping van asielzoekers. Phaxx, 10, 12-15.

Kramer, S., \& Bala, J. (2004). Managing uncertainty; coping styles of refugees in Western countries. Intervention, 2 (1), 33-42.

Kramer, S., \& Cense, M. (2004). Overleven op de M2: Veiligheidsbeleving en strategieën van vrouwen in de centrale opvang voor asielzoekers. Pharos/Transact. Utrecht.

Kraus, U., \& Zavalkink (2009). De mate van psychopathologie en interpersoonlijke problematiek. Tijdschrift voor Psychotherapie, 35 (2), 123-133.

Laban, C.J., Komproe, I.H., Gernaat, H.B., \& Jong, J.T. de. (2008). The impact of a long asylum procedure on quality of life, disability and physical health in Iraqi asylum seekers in the Netherlands. Soc Psychiatry Epidemiology, 43 (7), 507-515.

Laban, K. (2003). Wachten op een status is ziekmakend. Phaxx,10, 10-11.

Lam, P. (2002). Vrijwilligerswerk met een andere bril op. Wat vinden allochtonen van vrijwilligerswerk? Vakwerk 2. Utrecht: NOV/SVM.

Lamkaddem, M., \& Devillé, W. (2005). Health and health care use of asylum seekers and refugees in the Netherlands: a medical records study. In A.A.M. Gerritsen, H.M. van der Ploeg, W. Devillé \& M. Lamkaddem, 'Gevlucht-Gezond?' Een onderzoek naar de gezondheid van, en het zorggebruik door de asielzoekers en vluchtelingen in Nederland. Utrecht: NIVEL/VUmc.

Langley, A.K., \& Jones, R.T. (2005). Coping efforts and efficacy. Acculturation and post-traumatic symptomatology in Adolescents following wildfire. Fire Technology, 41 (2), 125-143.

Latour, S. (1978). Determinants of participant and observer satisfaction with adversary and inquisitorial modes of adjudication. Journal of Applied Psychology, 65, 355-356.

Lazarus, R.S. (1966). Psychological stress and the coping process. New York: Mac Graw Hil.

Lazarus, R.S. (1984). On the primacy of cognition. American Psychologist, 39, 124-129.

Lazarus, R.S. (2003). Does the positive psychology movement have legs? Psychological Inquiry, 14 (2), $93-109$.

Lazarus, R.S., \& Folkman, S. (1984). Stress, appraisal and coping. New York: Springer.

Leary, T. (1957). Interpersonal diagnosis of personality. New York: Oxford University Press. 
Leede, J. de. (1997). Innoveren van onderop. Over de bijdrage van taakgroepen aan product- en procesvernieuwing. Dissertatie UT.

Lemons, M.A., \& Jones-Coy, A. (2001). Procedural justice in promotion decisions: using perceptions of fairness to build employee commitment. Journal of Managerial Psychology, 16, 268-280.

Lengua, L.J., \& Stormshak, E.A. (2000). Gender, gender roles, and personality: gender differences in the prediction of coping and psychological symptoms. Sex Roles, 43, 787-820.

Leung, K., \& Li, W.K. (1990). Psychological mechanism of process-control effects. Journal of Applied Psychology, 6, 613-620.

Leventhal, G.S. (1976). The distribution of rewards and resources in groups and organizations. In L. Berkowitz, \& E. Walster (Eds.), Advances in Experimental Social Psychology, 9 (pp. 31-91). New York: Academic Press.

Leventhal, G.S. (1980). What should be done with equity theory? New approaches to the study of fairness in social relationships. In K. Gergen, M. Greenberg, \& R. Willis (Eds.), Social exchange: advances in theory and research (pp. 27-55). New York, Plenum.

Lifton, R.J. (1979). The broken Connection: on death and the Continuity of life. New York: Simon and Schuster.

Lin, E.H.B., Ihle, L.J., \& Tazuma, L. (1985). Depression among Vietnamese refugees in primary care clinic. American Journal of Psychiatry, 78, 41-44.

Lind, A. (1998). When do we need procedural fairness? The role of trust in authority. Journal of Personality and Social Psychology. 75 (6), 1449-1458.

Lind, E.A., \& Tyler, T.R. (1988). The social psychology of procedural justice. New York: Plenum.

Lind, E.A., Kurtz, S., Musante, L., Walker, L., \& Thibaut, J. (1980). Procedure and outcome effects on reaction to adjudicated resolution of conflicts of interest. Journal of Personality and Social Psychology, 39, 643653.

Lind, E.A., Lissak, R.I., \& Conlon, D.E. (1983). Decision control effects of procedural fairness judgment. Journal of Applied Social Psychology, 4, 338-350.

Lindencrona, F., Ekblad, S., Hauff, E. (2008). Mental health of recently resettled refugees form the Middle East in Sweden: the impact of pre-resettlement trauma, resettlement stress and capacity to handle stress. Social Psychiatry Epidemiology, 43, 121-131.

Lindo, F. (1994). Het stille succes: de sociale stijging van Zuid-Europese arbeidsmigranten in Nederland. In H.J. Vermeulen, \& R. Penninx (Red.), Het democratisch ongeduld: De emancipatie van zes doelgroepen van het minderhedenbeleid (pp. 117-144). Amsterdam: Het Spinhuis.

Littleton, H., Horsley, S., John, S., \& Nelson, D.V. (2007). Trauma, coping strategies and psychological distress: a meta-analysis. Journal of Traumatic Stress, 20 (6), 977-988.

Lloyd, D.A., \& Turner, R.J. (2003). Cumulative adversity and posttraumatic stress disorder: Evidence from a diverse community sample of young adults. American Journal of Orthopsychiatry, 73 (4), 381-391.

Lock, M. (2005). De asielzoeker zieker door gepieker? De asielzoeker tobt - wat helpt, dat het stopt? Onderzoeksverslag van een sociaal verpleegkundige te AZC Paalte.

Lommen, M.J.J., Sanders, A.J.M.L., Buck, N., \& Arntz, A. (2008). Psychosocial predictors of chronic post traumatic stress disorder in Sri Lankan tsunami survivors. Behavior Research and Therapy, 1-6.

Maas, J., Dam, A. van, \& Wismeijer, A. (2009). Het effect van actieve coping in protocollaire behandeling, Directieve Therapie, 29 (2), 127-138.

MacKinnon, D.P. (2008). Introduction to Statistical Mediation Analysis. New York: Erlbaum.

Markus, H.R., \& Kitayama, S. (1991). Culture and the self: Implications for cognition, emotion and motivation. Psychological Review, 98, 224-253.

Marrewijk, L. van. (1997). Narahati dan wel een depressie. Klachten van depressieve aard bij Iraniërs. Doctoraalscriptie. Culturele antropologie. Amsterdam: Vrije Universiteit Amsterdam.

Matheson, K., Jorden, S., \& Anisman, H.Y. (2008). Relations between trauma experiences and psychological, physical, and neuroendocrine functioning among Somali refugees. Mediating pole of coping with acculturation stress. Journal of Immigrant and Minority Health, 10 (4), 291-304. 
McAllister, D.J. (1995). Affect- and cognition-based trust as foundations for interpersonal cooperation in organizations. Academy of Management Journal, 38 (1), 24-59.

Meijer, P.C. (1999). Teachers' practical knowledge: Teaching reading comprehension in secondary education. Dissertatie Universiteit Leiden.

Meredith, L.S., Wenger, N., Liu, H., \& Khan, K. (2000). Development of a brief scale to measure acculturation among Japanese Americans. Journal of Community Psychology, 28, 103-113.

Merriam, S.B. (1988). Case study research in education: A qualitative approach. San Francisco/London: Jossey-Bass.

Meylemans, H. (2005). Methodieken: Het lichaam als uitgangspunt in psychotherapie bij vluchtelingen. In Goede praktijkvoorbeelden uit de hulpverlening aan vluchtelingen. Gent: Tanghe Printing.

Mezzich, J.E., Kleinman, A., \& Fabrega, J.E.A. (1993). Revised cultural proposals for DSM-IV (technical report). Pittsburgh, PA, NIMH. Culture and Diagnosis Group.

Mghir, R., Freed, W., Paskin, A., \& Katon, W. (1995). Depression and post traumatic stress disorder among a community sample of adolescent and young adult Afghan refugees. The Journal of Nervous and Mental Disease, 183 (1), 24-30.

Michalowski, I., Snel, E., Svensson, J., \& Thränhardt, D. (2006). Nieuwkomers integreren. Een vergelijkende evaluatie van lokale programma's in Munster en Enschede. Munster.

Mikulincer, M., \& Shaver, P.R. (2007). Attachment in adulthood: structure, dynamics, and change. Guildford Press.

Mikulincer, M., \& Shaver, P.R. (2009). An attachment and behavioral system perspective on social support. Journal of Social and Personal Relationships, 26 (1), 7-19.

Miles, J.N.V. (2005). Several entries: Central Limit Theorem, Regression Diagnostics, Regression Residuals, Residuals Plots. In D. Howell, \& B. Everitt (Eds.), The Encyclopedia of Statistics in Behavioral Science. Chichester: Wiley.

Miles, J.N.V., \& Shelvin, M. (2001). Applying regression and correlation. London: Sage.

Miles, M.B., \& Huberman, A.M. (1994). Qualitative Data Analysis. An expanded Sourcebook. Second Edition Thousand Oaks. London/New Delhi: Sage.

Mol, S.S.L., Arntz, A., \& Metsemakers, J.F.M. (2005). Symptoms of post-traumatic stress disorder after non-traumatic events: evidence from an open population study. British Journal of Psychiatry, 186, 494499.

Mollica, R.F., Caspi-Yavin, Y., Lavelle, J., Bollini, P., Truong, T., Tor, S., \& Lavelle, J. (1992). The Harvard Trauma Questionnaire: Validity al cross-cultural instrument for measuring torture, trauma, and posttraumatic stress disorder in Indochinese refugees. The Journal of Nervous and Mental Disease, 190, 11-116.

Mollica, R.F., Caspi-Yavin, Y., Lavelle, J., Tor, S., Yang, T., Chan, S., Pham, T., Ryan, A., De Marneffe, D. (1996). The Harvard Trauma Questionnaire (HTQ) Manual for use with Cambodian Lao and Vietnamese versions. Torture, 6, 5-21.

Mollica, R.F., Mc Donald, L.S., Massagli, M.P., \& Silove, D.M. (2004). Measuring trauma, measuring torture. Harvard Program in refugee trauma. Cambridge. MA.

Mollica, R.F., Sarajlic, N., Chernoff, M., Lavelle, J., Vukovic, I.S., \& Massagli, M.P. (2001). Longitudinal study of psychiatric symptoms, disability, mortality and emigration among Bosnian refugees. JAMA, 286, 546-554.

Momartin, S., Silove, D., Manicavasgar, V., \& Steel, Z. (2004). Comorbidity of PTSD and depression: associations with trauma exposure, symptoms severity and functional impairment in Bosnian refugees resettled in Australia. Journal of Affective Disorders, 80, 231-238.

Mooren, T.T.M., Jong, K. de, Kleber, R.J., \& Ruvic, J. (2003). The efficacy of a mental health program in Bosnia-Herzegovina: impact on coping and general health. Utrecht: Willey.

Morris, P., \& Silove, D.M. (1992). Cultural influence in psychotherapy with refugees survivors of torture and trauma. HOSP Community Psychiatry, 43, 820-824.

Mosher, C.E., \& Prelow, H.M. (2007). Active and avoidant coping and coping efficacy as mediators of de relation of maternal involvement to depressive symptoms among urban adolescents. Journal of Affective Disorders, 82, 315-320. 
Murphy, H.B.M. (1965). Migrants and the major mental disorders: A reappraisal. In M.B. Kantor (Ed.), Mobility and Mental Health. Springfield: Thomas.

Murray, E. (2002). Challenges in educational research. [Commentaries] Medical Education, 36, 110-112.

Muskens-Lepelstraat, G. (2008). Jongeren en integratie: onderzoek naar de eigen mening van de jongeren in Amsterdam-West, Rotterdam-Zuid, Amsterdam-Noord en elders. DOCA Bureaus.

Naumann, S.E. (1998). A case for procedural justice climate: Development and test of a multilevel model. Humanities and Social Sciences, 59 (6-A): 201.

Naumann, S.E., Bennett. N. (2000). Development and test of a multi level model. Academy of Management Journal, $43(5), 881-884$.

Negy, C., \& Woods, D.J. (1992a). The importance of acculturation in understanding research with Hispanic Americans. Hispanic Journal of Behavioral Science, 14, 224-247.

Nguyen, H. (2006). Acculturation in the United States. In D. Sam, \& J. Berry (Eds.), Cambridge Handbook of Acculturation Psychology (pp. 311-330). United Kingdom: Cambridge University Press.

Nguyen, H., \& von Eye, A. (2002). The Acculturation Scale for Vietnamese adolescents: A bidimensional perspective. International Journal of Behavior Development, 26 (30), 202-213.

Nguyen, S.D. (1989). Psychiatric and psychosomatic problems among Southeast Asian refugees, Ottawa: UN/Ottawa.

Nekuee, S., \& Verkuyten, M. (1999). Emotionele distantie en integratie: Iraanse politieke vluchtelingen in Nederland. Mens en Maatschappij, 75 (3), 218-234.

Neuner, F., Schauer, M., Karunakara, U., Klaschik, C., Robert, C., \& Elbert, T. (2004). Psychological trauma and evidence for enhanced vulnerability for posttraumatic stress disorder through previous trauma among West Nile refugees. BioMed Central psychiatry, 4, 1-7.

Nievaard, A.C. (1990). Validiteit en betrouwbaarheid in kwalitatief onderzoek. In I. Maso, \& A. Smaling (Red.), Objectiviteit in kwalitatief onderzoek (pp. 76-96). Meppel: Boom.

Nooteboom, B., Berger, H., \& Noorderhaven, N.C. (1997). Effects of trust and governance on relational risk. Academy of Management Journal, 40 (2), 308-338.

Oetzel, J., \& Ting-Toomey, S. (Eds.). (2006). The sage handbook of conflict communication. Integrating theory. Research and Practice. California: Sage Publication.

Olff, M., \& Vries, G.J. de. (2004). Prevalence of trauma and PTSD in the Netherlands. Proceedings of the $20^{\text {th }}$ Annual Meeting of the International Society for Traumatic Stress Studies. 14-18 november, New Orleans, USA.

Olff, M., Langeland, W., \& Gersons, B.P.R. (2005). The psychology of PTSD: coping with trauma. Psychoneuroendocrinology, 30, 974-982.

Ommeren, M. van, Sharma, B., Sharma, G.K., Komproe, I., Gardena, E., Jong, J.T. de. (2002). The relationship between somatic and PTSD symptoms among Bhutanese refugees torture survivors: examination of comorbidity with anxiety and depression. Journal of Traumatic Stress, 15 (5), 415-421.

Oostrum, I. van, Goosen, S., Uitenbroek, D., Koppenaal, D., Stronks, K. (2011). Mortality and causes of death among asylum seekers in the Netherlands, 2002-2005. Epidemiol Community Health 2011; 65: 376-383.

Orbe, M., \& Everett, M. (2006). Interactional and interethnic conflict and communication in the United States. In J. Oetzel, \& S. Ting-Toomey (Eds.), The Sage handbook of conflict communication. Integrating theory. Research and Practice (pp. 575-594). California: Sage Publications.

Orthel, M. (2004). Gezond AZC: Samen werken aan gezondheidsbevordering in een AZC. Uitgave van GGD. (Gemeentelijke Gezondheidsdienst) Nederland en COA.

Oudenhoven, J.P. van. (2000). Omgaan met culturele verschillen. Multiculturele effectiviteit op maatschappelijk, bedrijfs- en individueel niveau. Gedrag en Organisatie, 13 (3), 129-149.

Oudenhoven, J.P. van, Prins, K.S., \& Buunk, B.P. (1998). Attitudes of minority and majority members towards adaptation of immigrants. European Journal of Social Psychology, 28, 995-1013. 
Oudenhoven, J.P. van, Willemsma, G., \& Prins, K. (1996). Integratie en assimilatie van Marokkanen, Surinamers en Turken in Nederland. De Psycholoog, 31, 468-471.

Ozer, E.J., Best, S.R., Lipsey, T.L., \& Weiss, D.S. (2003). Predictors of posttraumatic stress disorder and symptoms in adults: a meta analysis. Psychological Bulletin, 129 (2), 52-73.

Pen, M., \& Tissing, H.A. (2000). Vluchtelingen op de arbeidsmarkt in de sector zorg en welzijn. Leiden: OSA-publicatie.

Penedo, F., Antoni, M.H., Schneiderman, N., Ironson, G.H., Malow, R.M., Cruess, S., Hurwitz, B., \& LaPerriere, A. (2001). Dysfunctional attitudes, coping and depression among HIV-seropositive men who have sex with men. Cognitive Therapy and Research, 25, 591-606.

Penley, J.A., Tomaka, J., \& Wiebe, J.S. (2002). The association of coping to physical and psychosocial health outcomes: A meta-analytic review. Journal of Behavioral Medicine, 25, 551-603.

Penninx, R. (1988). Minderheidsvorming en emancipatie: balans van kennisverwerving ten aanzien van immigranten en woonwagenbewoners, 1967-1987. Alphen aan den Rijn \& Brussel: Samson.

Penninx, R. (2004). Integration of migrants: economics, social, cultural and political dimensions. Background paper for the sessions on International migration: promoting management and integration.

Penninx, R., \& Schrover, M. (2002). Bastion of bindmiddel. De organisatie van migranten in een lange-termijn perspectief. Programma Sociale Cohesie/De Nederlandse Multiculturele en Pluriforme Samenleving. Universiteit van Amsterdam.

Pernice, R., \& Brook, J. (1996). Refugees and immigrants mental health: association of demographic and post immigration factors. Journal of Social Psychology, 136, 511-520.

Phalet, K. (2003). A cross-cultural analysis of immigrant and host values and acculturation orientations. In H. Vinken, J. Soeters, \& P. Ester (Eds.), Comparing Cultures. Leiden: Brill.

Pol, M.C. van der. (1995). Depressie bij vluchtelingen: een literatuuronderzoek. Scriptie in het kader van huisartsenopleiding. Utrecht: Universiteit Utrecht.

Poortinga, Y.H., Berry, J.W., Dasen, P.R., \& Segall, M.H. (1993). Cross-Cultural Psychology: Research and Application. New York: Cambridge University Press.

Porter, M., Haslam, N. (2005). Predisplacement and Post displacement Factors Associated With Mental Health of Refugees and internally Displaced Persons. A Meta-analysis. JAMA, 294 (5), 602-612.

Postel, A.A., \& Boekhoorn, P.F.M. (1993). Een wereld van verschil. Ervaring van vluchtelingen in Nederland. Nijmegen: OABG.

Priebe, S., \& Esmaili, S. (1998). Lang term mental sequelae of torture in Iran-who seeks treatment. The Journal of Nervous and Mental Disease, 185 (2), 74-77.

Prins, B.(1993). Multiculturalisme als een theorie van rechtvaardigheid. Migrantenstudies, 2, 117-129.

Prins, J.B.A., \& Linden, A.J. van der. (1999). Buitengewoon talent. Nijmegen: Druk \& Vorm.

Ramaekers, E. (2003). Trajectbegeleiding: waargenomen kansen: een onderzoek onder werklozen, werkgevers en begeleiders in Belgisch-Limburg. Doctoraatthesis. Heerlen: Open Universiteit Nederland.

Ramakers, J. (1995). De asielzoekers. Leuven: Davidsfonds.

Rath, J. (1999). Minorisering, de sociale constructie van etnische minderheden. Amsterdam: SUA.

Redfield, R., Linton, R., \& Herskovits, M.J. (1936). Memorandum on the study of acculturation. American Anthropologist, 38, 149-152.

Regina, P., \& Brook, J. (1997). Refugees and immigrant's mental health: association of demographic and post immigration factors. Journal of Social Psychology, 136 (4), 397-410.

Reichle, B., \& Gefke, M. (1998). Social-Justice Research, 11 (3), 271-287.

Rholes, S.W., \& Simpson, J.A. (Eds.). (2004). Adult attachment: theory, research and clinical implications. New York: Guilford Press.

Richters, J.M. (1991). De medisch antropoloog als een vertaler. Delft: Eubron.

Ridder, D.T.D. de, Heck, G.L. van, Endler, N.S., \& Parker, J.D.A. (2004). Coping Inventory for stressful situation: CISS handleiding. Lisse: Swets \& Zeitlinger. 
Rijnders, R. (2002). De rol van de therapeut in de behandeling van getraumatiseerde asielzoekers en vluchtelingen. In E. van Meekeren, A. Limburg-Okken, \& R. May (Red.), Culturen binnen psychiatriemuren. Amsterdam: Boom.

Roccas, S., Horenczyk, G., \& Schwartz, S.H. (2000). Acculturation, discrepancies and well-being: the moderating role of conformity. European Journal of Social Psychology, 30, 323-334.

Roelandt, T., \& Veenman, J. (1991). Een etnische onderklasse in Nederland? Migrantenstudies, 7 (3), 21-38.

Rohlof, J.G.B.M. (2003). Migratie en gezondheid bij vluchtelingen. In M. Braakman, M. Mensinga, \& J. Rohlof, Culturen zonder muren. Badhoevedorp: Mension.

Rotter, J.B. (1966).Generalized expectations for internal versus external control of reinforcement. Psychological Monographs, 80 .

Rousseau, D.M., Sitkin, S.B., Burt, R.S., \& Camerer, C. (1998). Not so different after all: A cross-discipline view of trust. Academy of Management review, 23, 393-404.

Rudmin, F.W., \& Ahmadzadeh, V. (2001). Psychochometric critique of acculturation psychology: the case of Iranian immigrants in Norway. Scandinavian Journal of Psychology, 42, 41-56.

Sadock, B.J., \& Sadock, V.A. (2003). Synopsis of Psychiatry. Philadelphia: Lippincott Williams \& Wilkins.

Schaufeli, W., \& Dierendonck, D. van. (1992). De betrouwbaarheid en validiteit van de Utrechtse Copinglijst. Gedrag en Gezondheid, 20 (1), 38-45.

Scheepers, P., Coenders, M., \& Lubbers, M. (2004). Historisch overzicht van etnocentrische reacties in Nederland aan het eind van de $20^{\text {ste }}$ eeuw. Tijdschrift voor Beleid, Politiek \& Maatschappij, 30, 80-89.

Schnider, K.R., Elhai, J.D., \& Gray, M.J. (2007). Coping style use as predicts post traumatic stress and complicated grief symptom severity among college students reporting a traumatic loss. Journal of Counseling Psychology, 54, 344-350.

Schnurr, P.P., Friedman, M.J., \& Benardy, N.C. (2002). Research on post traumatic stress disorder: Epidemiology, pathophysiology, and assessment. Psychotherapy in Practice, 58 (8), 877-889.

Schoormans, J., \& Grumbkow, J. von. (1988). Attitudes towards the Dutch social security system. In S. Maital (Ed.), Applied behavioral economics. Amsterdam: North Holland, Elsevier.

Schoormans, J., \& Syroit, J. (1989). Rechtvaardigheidsoordelen over het sociale zekerheidsstelsel in Nederland. In G.J.M. Jehoel-Gijbers (Red.), Leven met een uitkering. Tilburg: Katholieke Universiteit Brabant. IVA.

Schreurs, P.J.G., Tellegen, B., Willige, G. van de, \& Brosschot, J.F. (1988). De Utrechtse Copinglijst: UCL-herziene Handleiding: Lisse: Swets \& Zeitlinger.

Schwarz-Nielsen K.H., \& Elklit, A. (2009). An evaluation of the mental status of rejected asylum seekers in two Danish asylum centers. TORTURE $19(1), 51-59$.

Schweitzer, R., Melville, F., Steel, Z., \& Lacherez, P. (2006). Trauma, post-migration living difficulties, and social support as predictors of psychological adjustment in resettled Sudanese refugees. Australian \& New Zealand Journal of Psychiatry, 40, 179-187.

Seeleman, C., Suurmond, J., \& Stronks, K. (2005). Een arts van de wereld: etnische diversiteit in de medische praktijk. Houten: Bohn Stafleu van Loghum.

Seiffge-Krenke, I., \& Klessinger, N. (2000). Long-term effects of avoidant coping on adolescents' depressive symptoms. Journal of Youth and Adolescence, 29, 617-630.

Seligman, M.E.P., \& Csikszentmihalyi, M. (2000). Positive psychology. An introduction. American Psychologist, 55 (1), 5-14.

Shadid, W.A. (1998). Grondslagen van interculturele communicatie: studieveld en werkterreinen. Houten/Degem: Bohn Stafleu van Loghum.

Shadid, W.A. (2007). Grondslagen van interculturele communicatie: studieveld en werkterreinen. Hoofddorp: Wolters Kluwer Business.

Shen, B.J., \& Takeuchi, D.T. (2001). A structural model of acculturation and mental health status among Chinese Americans. American Journal of Community Psychology, 29, 387-418.

Shon, S.P., \& Ja, D.Y. (1982). Asian families. In M. McGoldrick, J.K. Pearce, \& J. Giordano (Eds.), Ethnicity and Family therapy. (pp. 208-228). New York: Guilford Press. 
Shrestha, N.M., Sharma, B., Ommeren, M. van, Regmi, S., Makaju, R., Komproe, I., Shrestha, G.B., \& Jong, J.T.V.M. de. (1998). Impact of torture on refugees displaced within the developing world: sympathology among Bhutanese refugees in Nepal. Journal of the American Medical Association, 280, 443-448.

Shrout, P.E., Link, B.G., Dohrenwend, B.P., Skodol, A.E., Stueve, A., \& Mirotznik, J. (1989). Characterizing life events as risk factor depression: the role of faithful loss events. Journal of Abnormal Psychology, 98, 460-467.

Siegel, P., Brockner, J., \& Tyler, T. (1995). Revisiting the relationship between procedural and distributive justice: the role of trust. Paper presented at the Academy of Management conference, Vancouver.

Silove, D., \& Ekblad, S. (2002). How well do refugees adapt after resettlement in Western countries? Acta Psychiatrica Scandinavia, 106, 401-402.

Silove, D., Manicavasagar, V., Cello, M., \& Aroche, J. (2005). PTSD, depression and acculturation. Intervention, $3(1), 46-50$.

Silove, D., Manicavasagar, V., Mollica, R., Mengthai, M., Khiek, D., Lavelle, J., \& Svangtor, B.A. (2007). Screening for depression and PTSD in Cambodian population unaffected by war. The Journal of Nervous and Mental Disease, 195 (2), 152-157.

Silove, D., Steel, Z., \& Watters, C. (2000). Policies of deterrence and the mental health of asylum seekers in Western countries. JAMA, 284, 604-611.

Silove, D., Steel, Z., Mc Gorr, P., Miles, V., \& Drolony, J. (2002). The impact of torture on post traumatic stress symptoms in war affected Tamil refugees and immigrants. Comprehensive Psychiatry, 43, 49-55.

Singareddy, R.K., \& Balon, R. (2002). Sleep in Posttraumatic Stress Disorder. Annals of Clinical Psychiatry, 14, 183-189.

Smaling, A. (1987). Methodologische objectiviteit en kwalitatief onderzoek. Lisse: Swets \& Zeitlinger.

Snel, E. (2003). Allochtonen in de WAO. In B. Wiendels (Ed.), Gemeentelijke arbeidsmarktbeleid gericht op participatie van iedereen, vol 6 (pp. 53-58). Den Haag: VNG uitgeverij.

Snel, E., Boonstra, N. (2005). De waarde van interetnisch contact: een onderzoek over initiatieven en beleidsprojecten om interetnisch contact te bevorderen. Raad van Maatschappelijke Ontwikkeling (RMO). Den Haag.

Stein, H., Koontz, A.D., Fonagy, P., Allen, J.G., Fultz, J., Brethour, J.R., Jr., Allen, D., \& Evans, R.B. (2002). Adult attachment: What are the underlying dimensions. Psychology and psychotherapy: Theory, Research and Practice, 75, 77-91.

Stern, D.N. (1977). The first relationship: infant and mother, London: Fontana. Open Books.

Stevens, G.W.J.M., Volleberg, W.A.M., Pels, T.V.M., \& Crijnen, A.A.M. (2005). Patronen van acculturatie en probleemgedrag bij Marokkaanse jongeren in Nederland. Nederlands Tijdschrift voor de Psychologie, 60 (05), 163-173.

Swanborn, P.G. (1987). Methoden van sociaal-wetenschappelijk onderzoek. Amsterdam/Meppel: Boom.

Swanborn, P.G. (1996). Case-study's: Wat, wanneer en hoe? Amsterdam/Meppel: Boom.

Syroit, J., Grumbkow, J. von, \& Ramaekers, E. (2007). Vertrouwen in kansen van kansgroepen: een onderzoek onder werkzoekenden en werkgevers naar de waargenomen kansen op de arbeidsmarkt. In S. Prins, S. Schruijer, J. Verboven, \& K. de Witte (Red.), Diversiteit en vertrouwen in sociale systemen (pp. 211-230). Leuven: Lannoo.

Taris, T.W., Peeters, M.C.W., Le Blanc, P.M., Schreurs, P.J.G., \& Schaufeli, W.B. (2001). From inequity to burnout: the role of job stress. Journal of Occupational Health Psychology, 6, 303-323.

Taylor, S. (2006). Clinician's guide to PTSD: a cognitive-behavioral approach. New York: Guilford Press.

Teunissen, J. (1985). Triangulatie als onderzoeksstrategie in symbolisch interactionistisch onderzoek. In W.A. Arts, H.W.A. Hilhorst, \& F. Wester (Eds.), Betekenis en interactie: Symbolisch interactionisme als onderzoeksperspectief (pp. 82-97). Deventer: Van Loghum Slaterus.

Thabet, A.A.M., Abed, Y., Vostanis, P. (2004). Co-morbidity of PTSD and depression among refugee children during war conflict. Journal of Child Psychology and Psychiatry, 45, 533-542.

Thibaut, J., \& Walker, L. (1975). Procedural justice: A psychological analysis. Erlbaum: Hillsade/NJ.

Thibaut, J., \& Walker, L. (1978). A theory of procedure. California: Law Review, 66, 541-566. 
Thompson, S.C., Armstrong, W., Thomas, C. (1998). Illusions of control, under estimation and accuracy. A control heuristic explanation. Psychological Bulletin, 123, 143-161.

Tillaart, H. van den, Olde Monnikhof, M., Berg, S. van den, \& Warmerdam, J. (2000). Nieuwe etnische groepen in Nederland: een onderzoek onder vluchtelingen en statushouders uit Afghanistan, Ethiopië en Eritrea, Iran, Somalie en Vietnam. Nijmegen: Instituut voor Toegepaste Sociale Wetenschappen.

TNS/NIPO. (1998 \& 2004). http://www.tns-nipo.com/persbericht/immigranten.

Toar, M., O'Brien, K.K., \& Fahey, T. (2009). Comparison of self-reported health and health care utilisation between asylum-seekers and refugees: an observational study. BMC. Public Health, 9, 214.

Trahan, P.E. (1995). Dealing with difficulties of return in Orange County. Humanities and-Social-Sciences, 56 (4-A): 1412.

Triandis, H.C. (1989). The self and social behavior in differing cultural context. Psychological Bulletin, 96, 506-520.

Triandis, H.C. (1990). Cross-Cultural studies of individualism and collectivism. In J. Berman (Ed.), Nebraska Symposium on motivation, 1989 (pp. 41-188). Thousand Oaks, CA: Sage.

Triandis, H.C. (1994). Culture and social behavior. New York Mc Graw-Hill.

Triandis, H.C. (1995). A theoretical framework for the study of diversity. In M.M. Chemers, S. Oskamp, \& M.A. Costanzo (Eds.), In Diversity in Organizations: New perspectives for a changing workforce (pp. 11-36). California: Sage Publications.

Triandis, H.C. (2001). Individualism-collectivism and personality. Journal of Personality, 69 (6), 907-924.

Triandis, H.C., \& Gelfand, M. (1998). Converging measurement of horizontal en vertical individualism and collectivism. Journal of Personality and Social Psychology, 74, 118-128.

Tropp, L.R., Erkut, S., Coll, C.G., Alarcón, O., \& Garcia, H.A.V. (1999). Psychological acculturation: development of a new measure for Puerto Ricans on the US mainland. Educational and Psychological Measurement, 59, 351-367.

Tseng, W.S. (2001). Handbook of cultural psychiatry. San Diego, CA: Academic Press.

Tyler, T.R. (1988). What is procedural justice? Criteria used by citizens to assess the fairness of legal procedures. Law and Society Review, 22, 103-135.

Tyler, T.R., \& Folger, R. (1980). Distributional and procedural aspects of satisfaction with citizen-police encounters. Basic and Applied Social Psychology, 1, 281-292.

Tyler, T.R., \& Lind, E.A. (1992). A relational model of authority in groups. In M.P. Zanna (Ed.), Advances in Experimental Social Psychology, 25 (pp. 115-191). San Diego/CA: Academic Press.

Tyler, T.R., Degoey, P., \& Smith, H. (1996). Understanding why the justice of group procedures wasters: A test of the psychological dynamics of the group-value model. Journal of Personality and Social Psychology, 70 (5), 913-930.

Tyler, T.R., Rasinski, K., \& McGraw, K.M. (1985). The influence perceived in justice on the endorsement of political leaders. Journal of Applied Psychology, 15, 700-725.

Tyler, T.R., Rasinski, K., \& Spodick, N. (1985). The influence of voice on satisfaction with leaders: Exploring the meaning of process control. Journal of Personality and Social Psychology, 48, 72-81.

Tyler, T.R., \& Schuller, R. (1990). A relational model of authority in work organization: The psychology of procedural justice. Manuscript. American Bar Foundation.

Ullman, S.E., \& Fillipas, H.H. (2005). Gender differences in social reactions to abuse disclosures, post-abuse coping and PTSD of child sexual abuse survivors. Child abuse and neglect, 29, 767-782.

Vanmarcke, S. (2005). Asielprocedure; tussen hoop en vrees. Stressbeleving bij asielzoekers tijdens de asielprocedure. Eindwerkstuk derde jaar sociaal werk, optie maatschappelijk werk.

Vedder, P., \& Vijver, F.J.R. van de. (2003). De acculturatie en adaptatie van migranten in Nederland. Een vergelijkende studie. Migrantenstudies, 19 (4), 252-265.

Veenman, J. (1994). Maatschappelijke tweedeling en sociale cohesie. Assen: Van Gorcum.

Veer, G. van der. (1987). Psychische problemen van jonge Iraanse vluchtelingen. Jeugd en Samenleving, 17 (46), 354-365. 
Veer, G. van der. (1991). Hulpverlening en psychotherapie met vluchtelingen: een inleiding. In J. de Jong, \& M. van den Berg (Red.), Transculturele psychiatrie en psychotherapie. Handboek voor hulpverlening en beleid (pp. 173-183). Lisse: Swets \& Zeitlinger.

Veer, G. van der. (1998). Hulpverlening aan vluchtelingen. Psychische problemen en de gevolgen van traumatisering en ontworteling. Baarn: Uitgeverij Intro.

Vera, P. (1998). Dan is je spiegel gebroken: een onderzoek naar de problemen van vluchtelingen met gezondheid en gezondheidszorg in Nederland. Tilburg: $\mathrm{BOZ}$.

Verkuyten, M., \& Thijs, J. (2002). Racist victimization among children in the Netherlands: the effect of ethnic group and school. Ethnic and Racial Studies, 25, 310-331.

Vermeulen, H. (2002). Cultuur en ongelijkheid. De relatie tussen de eigen cultuur van immigrantengroepen en de ontwikkeling van hun maatschappelijke positie. Programma Sociale Cohesie. De Nederlandse Multiculturele en Pluriforme Samenleving. Amsterdam: Universiteit van Amsterdam.

Vermeulen, J., \& Penninx, R. (Red.). (1994). Het democratisch ongeduld; de emancipatie en integratie van zes deelgroepen van het minderheidsbeleid. Amsterdam. Het Spinhuis.

Vermunt, R., \& Steensma, H. (2005). 'How can justice be used to manage stress in organizations?' In J. Greenberg, \& J.A. Colquitt (Eds.), Handbook of Organizational Justice (pp. 383-410). Erlbaum: Mahwah, NJ.

Vijver, F.J.R. van de, Helms-Lorenz, M., \& Feltzer, M.F. (1999). Acculturation and cognitive performance of migrant children in the Netherlands. International Journal of Psychology, 34, 149-162.

Vijver, F.J.R. van de. (2001). Psychologie en de multiculturele samenleving. Katholieke Universiteit Brabant. Faculteit Sociale Wetenschappen.

Vocht, A. de. (2005). Basishandboek SPSS.13 voor Windows. Utrecht: Bijleveld Press.

Vollebergh, W.A.M. (1996). Identification with social groups and intolerance in Dutch adolescent. In R.F. Farnen, H. Dekker, R. Meyenberg, \& D.B. German (Eds.), Democracy, socialization and conflicting loyalties in East and West: Cross National and Comparatives (pp. 304-331). London: MacMillan Press.

Vollebergh, W.A.M. (2000). Etnische distantie en etnische affirmatie in de identiteitsontwikkeling van etnische jeugd. Nederlands Tijdschrift voor de Psychologie, 148-158.

Vries, S. de. (2002). Psychosociale hulpverlening en vluchtelingen. Zeist: A-D Druk.

Vries, T.A. de, \& Werve, E. van der. (1999). Werkeisen, coping en burn-out bij fysiotherapeuten. Nederlands Tijdschrift voor de Psychologie, 54, 219-226.

Wagenvoort, M.A., Yperen, N.W. van, Hoogduin, C.A.L., \& Schaap, C.P.D.R. (1998). Persoonskenmerken en burn-out: de mediërende rol van copingstijl. Nederlands Tijdschrift voor de Psychologie, 53, 128-143.

Waldrop, A.E., \& Resick, P.A. (2004). Coping among adult female victims of domestic violence. Journal of Family Violence, 19, 291-302.

Wallen, N.E., \& Frankel, J.R. (2001). Educational Research: A guide to the process. Mahwah N.J., London: Lawrence Erlbaum.

Weine, S.M., Vojvoda, D., Becker, D., Mc Glashan, T., Hodzic, E., Laub, D., Hyman, L., Sawyer, M., \& Lazove, S. (1998). PTSD symptoms in Bosnian refugees 1 year after resettlement in the US. American Journal of Psychiatry. 155 (4), 562-564.

Wester, F. (1995). Strategieën voor kwalitatief onderzoek. Bussum: Coutinho.

Westermeyer, J., Bouafuely, M., Neider, J., \& Callies, A. (1989). Somatization among refugees: an epidemiologic study. Psychosomatic, 30, 34-43.

Wheeler, L., Reis, H., \& Bond, M.H. (1989). Collectivism-Individualism in everyday social life: The middle kingdom and the meeting point. Journal of Personality and Social Psychology, 57, 79-86.

Wiggins, J.S. (1973). Personality and prediction: principles of personality assessment: Menlo Park, CA: Addison-Wesley.

Williams, C.L., \& Berry, J.W. (1991). Primary prevention of acculturative stress among refugees. American Psychologist. 4 (66), 632-641. 
Willigen, L.H.M. van. (2003). Het kind en het asielbeleid in praktijk: een inventarisatie van knelpunten ten aanzien van de waarborging van een zo ongestoord mogelijke ontplooiing en ontwikkeling van kinderen die naar Nederland zijn gekomen om asiel te verkrijgen. Den Haag: Adviescommissie voor Vreemdelingenzaken.

Willigen, L.H.M. van, Hondius, A.J.K., \& Ploeg, H.M. van der. (1995). Health problems of refugees in the Netherlands. Tropical and Geographical Medicine, 47 (30), 118-124.

Withuis, J. (1995). Cultuur en trauma. Kanttekeningen bij enige recente publicaties over vluchtelingenzorg. Symposium Cultuur en trauma op 15 december.

Yamada, K., Nagayama, H., Tsutiyama, K., Kitamura, T., \& Furukawa, T. (2003). Coping behavior in depressed patients: a longitudinal study. Psychiatry Research, 121, 169-177.

Yamaguchi, S. (1994). Collectivism among the Japanese: A perspective from the self. In U. Kim, H.C. Triandis, C. Kagitcibasi, S.C. Choi, \& G. Yoon (Eds.), Individualism and Collectivism: Theory, method, and applications (pp. 175-188). Thousand Oaks, CA: Sage.

Ybema, J.F. (2007). De invloed van rechtvaardigheid op werkuitkomsten: een longitudinaal perspectief. Gedrag \& Organisatie, 20 (4), 409-429.

Ybema, J.F., Sanders, J., \& Vroome, E. de. (2006). Cohortstudie arbeid, verzuim en gezondheid (AVG): Methodologie en eerste resultaten 2004-2006. Hoofddorp: TNO.

Yin, R.K. (1989). Case study research. Design and Method. Newbury Park/London/New Delhi: Sage.

Yin, R.K., \& Heald, K.A. (1975). Using the case survey method to analyze policy studies. Administrative Science Quarterly, 20, 371-381.

Zagefka, H., \& Brown, R. (2002). The relationship between acculturation strategies, relative fit and intergroup relations: Immigrant-majority relations in Germany. European Journal of Social Psychology. 36 (6), 369-389.

Zeidner, M. (2006). Individual differences in psychological to terror attack. Personality and Individual Differences, 40, 771-781.

Zheng, X., Sang, D., \& Wang, L. (2004). Acculturation and subjective well-being of Chinese students in Australia. Journal of Happiness Studies, 4 (1), 57-72.

Zonke, M. (1995). Dealing with difficulties to return to South-Africa: the role of social support and coping. Journal of Refugee Studies, 8 (2), 210-227.

Zwaan, A.H. van der. (1990). Organisatieonderzoek. Leerboek voor de praktijk: het ontwerpen van onderzoek in organisaties. Assen/Maastricht: Van Gorcum. 


\section{Dankwoord}

Graag wil ik van de gelegenheid gebruikmaken om alle mensen te bedanken die op wat voor manier dan ook hebben bijgedragen aan de totstandkoming van dit proefschrift.

Allereerst wil ik mijn promotor, prof. dr. Arnoud Arntz, bedanken voor de begeleiding in de afgelopen jaren. Arnoud, je hebt mij de kans en het vertrouwen gegeven om dit proefschrift, naast mijn klinische werk, voort te zetten en af te ronden. Je hebt mij met veel geduld begeleid en mij veel ruimte gegeven. Ik heb veel mogen leren van jouw scherpe wetenschappelijke en nauwkeurige manier van kijken naar mijn onderzoek.

Verder wil ik Erik Schouten van de Universiteit Maastricht noemen. Erik, je hebt mij enorm geholpen en gesteund bij de statistische analyses van de onderzoeksgegevens. Jouw geduld wat betreft het toepassen van herhaaldelijke analyses en jouw kalmte toen ik gestrest was, waren erg geruststellend. Zonder jouw begeleiding was er geen promotie en had ik deze studie niet tot een goed einde kunnen brengen.

Dank ook aan Rink en Ineke Rietveld, Coby Swart en Herman de Jong voor hun nauwe betrokkenheid bij mijn onderzoek en de niet aflatende hulp bij het corrigeren van de tekst. Rink, dank voor je voortdurende inzet bij het regelmatig corrigeren van de teksten.

Dank aan mijn zoon Ladbon, die mij gedurende het verrichten van deze studie met zijn leuke humor en emotionele steun de moed heeft gegeven om door te zetten. Mijn lieve Ladbon, je bent ook serieus bezig met je eigen promotieonderzoek. Jouw onderzoek vraagt van jou ook veel inzet en doorzettingsvermogen en ik weet het zeker dat je het met succes kunt afronden. Je weet hoe trots ik op je ben.

Ik wil ook graag mijn diepe waardering en dank betuigen aan Khosro Khajeh. Lieve Khosro, je bent mijn beste vriend, je hebt mij enorm bijgestaan gedurende de hele onderzoeksperiode. Je hebt het voor mij mogelijk gemaakt om diverse asielzoekerscentra te bezoeken. Je was betrokken bij het verzamelen en invoeren van de vele gegevens en bij de vele praktische werkzaamheden. Jouw emotionele en praktische steun tijdens de lastige fasen van dit proefschrift, kan ik niet genoeg waarderen.

Mijn speciale dank aan Jaap Zoetmulder. Van jou, Jaap, leerde ik veel van een aantal kritische opmerkingen over het theoretische deel van dit proefschrift. Daarnaast heb je mij enorm geholpen met de eerste opgemaakte versie van de tekst. Zonder jouw geduld en steun was me dit niet gelukt.

Mina Fasiholzaman, Parwin Shabazy en Mitra Aslani waren alle drie zeer betrokken bij het verzamelen van de gegevens en het benaderen van de respondentengroep van deze studie. Jullie zijn mij dierbaar, enorm bedankt voor jullie inzet. 
Mijn grote dank gaat ook uit naar alle mensen die als respondenten hebben meegedaan aan het onderzoek. Jullie bijdragen vormen de essentie van deze studie en ik ben jullie zeer erkentelijk voor het invullen van alle vragenlijsten en voor de interviews. Ik weet hoe zwaar het was om terug te kijken naar de moeilijke periodes, zowel in Iran als in Nederland. Jullie inspanningen, tips, kritische opmerkingen en ideeën heb ik zeer gewaardeerd.

En ik wil dit dankwoord besluiten met mijn dank aan de Leden van de promotiecommissie, dank voor het lezen van dit proefschrift.

Ik heb veel steun gekregen van mijn vrienden, vriendinnen en (ex-)collega's. Jullie hebben mijn verhalen gehoord, interesse getoond en mij de steun gegeven die ik nodig had om door te gaan.

Paranimfen, Marian en Sacha, jullie hebben niets met onderzoek te maken, maar wel met mij, gelukkig. Hartelijk dank voor jullie steun en fijn dat jullie me ook tijdens de verdediging bij willen staan.

En last but not least, mijn oprechte waardering en dank aan prof. dr. Jasper von Grumbkow en prof. dr. René van Hezewijk die mij bij aanvang en bij het verrichten van deze studie gedurende de eerste jaren hebben begeleid. 


\section{Curriculum vitae}

Mahnaz Tabesh is geboren op 22 februari 1956 in Teheran, Iran. In 1975 heeft ze haar middelbare school in Teheran afgerond. In hetzelfde jaar begon ze met de studie psychologie aan de universiteit in Teheran, een studie die vanwege haar gevangenschap en de culturele revoluties van het islamitische regime 10 jaar heeft geduurd. Ze kon uiteindelijk in 1984 haar masterstudie in klinische psychologie met succes afsluiten.

Van 1984 tot 1993 was Mahnaz werkzaam in Iran als klinisch psycholoog, zowel in haar eigen praktijk als in twee privéklinieken in Teheran. In Iran heeft Mahnaz meegewerkt aan diverse wetenschappelijke studies, zoals het effect van gedrags- en cognitieve therapie en biofeedback op het verminderen van chronische pijnklachten, het effect van gedragstherapie op het verminderen van negatieve symptomen bij schizofrenie, het effect van gedrags- en cognitieve therapie op het verminderen van chronische hoofdpijn, het effect van gedragstherapie bij stotteren en het standaardiseren van de Beck Depressie-vragenlijst en de Eysenck Persoonlijkheidsvragenlijst.

Mahnaz Tabesh kwam in 1994 naar Nederland en begon in 1996 haar aanvullende studie psychologie aan de Open Universiteit in Utrecht. Haar masterstudie richting gezondheidszorg kon ze in 2001 afronden. Tussen 2005 en 2008 heeft Mahnaz haar post-masteropleiding tot gedrags- en cognitieve therapeut afgerond en vervolgens in 2010 haar opleiding tot psychotherapeut met succes afgesloten. Mahnaz begon in 2003 met haar promotietraject, dat zij in Maastricht kon afronden.

Mahnaz Tabesh was van 2002 tot 2003 als studiebegeleidster werkzaam bij UAF Job Support (de stichting voor vluchteling-studenten) in Utrecht. Van 2003 tot 2011 heeft Mahnaz als psycholoog, gedragstherapeut en psychotherapeut gewerkt bij diverse GGZ-instellingen, zoals Altrecht in Zeist, Utrecht en Nieuwegein; Riagg Amersfoort en de Stichting Centrum 45.

Mahnaz heeft voor de gemeente Amersfoort diverse workshops georganiseerd over de psychische klachten en postmigratieproblemen bij vluchtelingen in het algemeen en Iraniërs in het bijzonder. Als externe promovenda heeft Mahnaz haar promotie voortgezet naast haar werkzaamheden als psycholoog. Sinds juli 2011 werkt Mahnaz als vrijgevestigde psychotherapeut in haar eigen praktijk in Amersfoort waar ze vooral getraumatiseerde vluchtelingen behandelt. 



\section{Bijlagen}

\section{Bijlage 1 Onderzoek 1}

Bijlage 1 tabel 1: Overzicht van de gegevens van respondenten en het integratiepatroon van onderzoek 1 voor de gehele groep met gemiddelde en spreiding.

Variabele

Aantal (148)

(ex-)vluchteling

Asielzoeker

Leeftijd

Geslacht

Man

Vrouw

Burgerlijke staat

Alleenstaand

Getrouwd

Gescheiden

Samenwonend

Opleiding

Lagere school

Middelbare school

MBO

$\mathrm{HBO}$

WO
Meetniveau Gemiddeld Frequency

$\%$

Min-Max SD 
VERVOLG Bijlage 1 Onderzoek 1

\begin{tabular}{|c|c|c|c|c|c|c|}
\hline Variabele & Meetniveau & Gemiddeld & Frequency & $\%$ & Min-Max & SD \\
\hline Werk & Nominaal & & & & & \\
\hline Ja & & & 53 & $36 \%$ & & \\
\hline Nee & & & 93 & $63 \%$ & & \\
\hline Overige & & & 2 & $1 \%$ & & \\
\hline Volgen stage & Nominaal & & & & & \\
\hline $\mathrm{Ja}$ & & & 45 & $30 \%$ & & \\
\hline Nee & & & 103 & $70 \%$ & & \\
\hline \multicolumn{7}{|l|}{ Studie } \\
\hline Bezig & & & 50 & $34 \%$ & & \\
\hline Afgerond & & & 69 & $47 \%$ & & \\
\hline Geen & & & 29 & $19 \%$ & & \\
\hline Integratie & Nominaal & & & & & \\
\hline Integratie & & & 128 & $87 \%$ & & \\
\hline Assimilatie & & & 7 & $5 \%$ & & \\
\hline Separatie & & & 2 & $1 \%$ & & \\
\hline Marginalisatie & & & 11 & $7 \%$ & & \\
\hline
\end{tabular}

Bijlagen 1 tabel 2: Overzicht van de mate van de beoordeling van emotionaliteit en zakelijkheid tussen twee landen, aantallen en percentages: $\mathrm{N}=148$.

\begin{tabular}{lcccc}
$\begin{array}{l}\text { Iraniër-veel } \\
\text { emotioneler }\end{array}$ & $\begin{array}{c}\text { Iraniër-beetje } \\
\text { emotioneler }\end{array}$ & Gelijke & $\begin{array}{c}\text { Nederlander-veel } \\
\text { emotioneler }\end{array}$ & $\begin{array}{c}\text { Nederlander-beetje } \\
\text { emotioneler }\end{array}$ \\
\hline $98(66 \%)$ & $29(20 \%)$ & $14(9 \%)$ & $4(3 \%)$ & $3(2 \%)$
\end{tabular}


Bijlage 1 tabel 3: Overzicht van de originele schalen van variabele kansperceptie, begeleidingsvariabelen en de genormeerde scores van de BDI, de SCL-90 en de UCL van onderzoek 1 (ex-vluchtelingen en asielzoekers) met gemiddelde en spreiding voor nominale en dichtome variabelen. De beschrijvende statistiek die wordt gegeven van Kansperceptie, Vertrouwen, Inspraak en Rechtvaardigheid is die van de originele schalen, vóór hercodering.

\begin{tabular}{lccccc} 
Variabele & Gemiddeld & Min & Max & SD & N \\
\hline Kansperceptie & 24 & 12 & 57 & 8.50 & 148 \\
Vertrouwen & 10 & 4 & 20 & 2.90 & 147 \\
Inspraak & 12 & 5 & 22 & 3.70 & 148 \\
Rechtvaardigheid & 24 & 10 & 45 & 6.60 & 147 \\
BDI & 2.40 & 1 & 4 & 1.60 & 148
\end{tabular}

SCL-90

AGO
DEP

SOM

IN

HOS

UCL

AC

PAL

VER

SOC

EXP 


\section{Bijlage 2: Analyses onderzoek 1}

Bijlage 2 tabel 1: Correlaties tussen de variabele kansperceptie en begeleidingsvariabelen, $\mathrm{N}=148$.

Variabele Tevredenheid Kans Rechtvaardigheid Inspraak Vertrouwen

Tevredenheid

Kans $.51^{* *}$

Rechtvaardigheid

$.85^{* *} \quad .46^{* *}$

Inspraak

$.85^{* *}$

$.40^{* *}$

$.55^{* *}$

Vertrouwen

$.91^{* *}$

$.46^{* *}$

$.68^{* *}$

$.69 * *$

${ }^{* *} p \leq .01$

Bijlage 2 tabel 2: correlaties tussen de variabele kansperceptie en psychopathologie variabelen, $\mathrm{N}=148$.

\begin{tabular}{|c|c|c|c|c|c|c|c|c|c|c|}
\hline Variabele & Kans & ANG & AGO & DEP & som & INA & SEN & HOS & SLA & ALG \\
\hline Kans & & & & & & & & & & \\
\hline ANG & $-.18^{*}$ & & & & & & & & & \\
\hline AGO & -.098 & $.69^{* *}$ & & & & & & & & \\
\hline DEP & $-.20^{*}$ & $.69^{* *}$ & $.53^{* *}$ & & & & & & & \\
\hline SOM & -.11 & $.72^{* *}$ & $.69^{* *}$ & $.54^{* *}$ & & & & & & \\
\hline INA & -.15 & $.71^{* *}$ & $.60^{* *}$ & $.70 * *$ & $.70^{* *}$ & & & & & \\
\hline SEN & -.16 & $.65^{* *}$ & $.64^{* *}$ & $.48^{* *}$ & $.56^{* *}$ & $.65^{* *}$ & & & & \\
\hline HOS & -.14 & $.58^{* *}$ & $.46^{* *}$ & $.48^{* *}$ & $.56^{* *}$ & $.61^{* *}$ & $.53^{* *}$ & & & \\
\hline SLA & -.054 & $.68^{* *}$ & $.60^{* *}$ & $.66^{* *}$ & $.58^{* *}$ & $.55^{* *}$ & $.60^{* *}$ & $.44^{* *}$ & & \\
\hline ALG & $-.17^{*}$ & $.81^{* *}$ & $.68^{* *}$ & $.85^{* *}$ & $.70^{* *}$ & $.76^{* *}$ & $.76^{* *}$ & $.56^{* *}$ & $.77^{* *}$ & \\
\hline
\end{tabular}


Bijlage 2 tabel 3: Correlatie tussen de variabele kansperceptie en de schalen van de copingstijlen, $\mathrm{N}=148$.

\begin{tabular}{|c|c|c|c|c|c|c|c|c|}
\hline Variabele & Kans & $A C$ & PAL & VER & SOC & PAS & EXP & GER \\
\hline \multicolumn{9}{|l|}{ Kans } \\
\hline$A C$ & .017 & & & & & & & \\
\hline PAL & -.082 & .15 & & & & & & \\
\hline VER & -.039 & $.35^{* *}$ & $.40^{* *}$ & & & & & \\
\hline SOC & $.170^{*}$ & $.28^{* *}$ & $.22^{* *}$ & .14 & & & & \\
\hline PAS & -.116 & $-.31^{* *}$ & $.20^{*}$ & $.18^{*}$ & -.067 & & & \\
\hline EXP & .052 & -.00 & .052 & -.054 & $.19^{*}$ & .047 & & \\
\hline GER & -.123 & $.47^{* *}$ & $.29 * *$ & $.28^{* *}$ & $.23^{* *}$ & -.096 & $.18^{*}$ & \\
\hline
\end{tabular}


Bijlage 2 tabel 4: t-toets voor variabelen kansperceptie, vertrouwen, inspraak, rechtvaardigheid en de genormeerde scores van de BDI, de SCL-90 en de UCL tussen asielzoekers (ex) vluchtelingen.

\begin{tabular}{|c|c|c|c|c|}
\hline Variabele & $M(s d)$ & $t$ & $\mathbf{N}$ & p-waarde \\
\hline Kans & $\begin{array}{l}33.54(9.42) \\
37.78(7.10)\end{array}$ & 3.08 & 148 & $.002^{* *}$ \\
\hline Inspraak & $\begin{array}{l}10.84(3.56) \\
14.00(3.24)\end{array}$ & 5.60 & 148 & $<.0001^{* *}$ \\
\hline Rechtvaardigheid & $\begin{array}{l}18.47(6.19) \\
22.64(6.45)\end{array}$ & 3.90 & 147 & $.0001^{* *}$ \\
\hline Vertrouwen & $\begin{array}{c}8.68(2.66) \\
10.52(3.05)\end{array}$ & 3.89 & 147 & $.0001^{* *}$ \\
\hline BDI & $\begin{array}{l}3.34(1.46) \\
2.31(1.55)\end{array}$ & 4.16 & 148 & $<.0001^{* *}$ \\
\hline \multicolumn{5}{|l|}{ SCL-90 } \\
\hline ANG & $\begin{array}{l}5.84(1.41) \\
5.23(1.56)\end{array}$ & 2.50 & 148 & $.014^{*}$ \\
\hline AGO & $\begin{array}{l}5.92(1.41) \\
4.93(1.96)\end{array}$ & 3.50 & 148 & $.01^{* *}$ \\
\hline DEP & $\begin{array}{l}6.16(1.31) \\
5.83(1.44)\end{array}$ & 1.50 & 148 & .139 \\
\hline SOM & $\begin{array}{l}5.29(1.79) \\
5.19(1.77)\end{array}$ & .34 & 148 & .73 \\
\hline IN & $\begin{array}{l}5.67(1.78) \\
5.59(1.38)\end{array}$ & .31 & 148 & .75 \\
\hline SEN & $\begin{array}{l}6.10(1.22) \\
5.69(1.38)\end{array}$ & 1.90 & 148 & .063 \\
\hline HOS & $\begin{array}{l}5.79(1.47) \\
5.83(1.32)\end{array}$ & -.14 & 148 & .88 \\
\hline SLA & $\begin{array}{l}5.85(1.22) \\
5.12(1.74)\end{array}$ & 2.90 & 148 & $.004^{* *}$ \\
\hline PSNEUR & $\begin{array}{l}6.15(1.39) \\
5.57(1.57)\end{array}$ & 2.30 & 148 & $.019^{*}$ \\
\hline \multicolumn{5}{|l|}{ UCL } \\
\hline$A C$ & $\begin{array}{l}2.82(.99) \\
3.11(.89)\end{array}$ & 1.83 & 148 & .070 \\
\hline PAL & $\begin{array}{l}3.62(.95) \\
3.25(.96)\end{array}$ & 2.31 & 148 & $.020^{*}$ \\
\hline VER & $\begin{array}{l}3.33(.97) \\
3.36(.81)\end{array}$ & .21 & 148 & .80 \\
\hline SOC & $\begin{array}{l}3.11(.96) \\
3.37(.92)\end{array}$ & 1.70 & 148 & .09 \\
\hline PAS & $\begin{array}{l}4.37(.73) \\
3.93(.87)\end{array}$ & 3.15 & 148 & $.01^{* *}$ \\
\hline EXP & $\begin{array}{l}3.21(.79) \\
3.41(.84)\end{array}$ & .23 & 146 & .12 \\
\hline GER & $\begin{array}{l}3.71(.88) \\
3.65(.92)\end{array}$ & .40 & 146 & .7 \\
\hline
\end{tabular}




\section{Bijlage 3}

Bijlage 3 tabel 1: Algemene informatie en het integratiepatroon van onderzoek 3 voor de gehele groep met gemiddelde en spreiding.

\begin{tabular}{|c|c|c|c|c|c|}
\hline Variabele & Meetniveau & $\mathbf{N}$ & $\%$ & Min-Maximum & SD \\
\hline Aantal (119) & & 119 & & & \\
\hline (ex-)vluchteling & & 64 & $54 \%$ & & \\
\hline Pardonregeling & & 55 & $46 \%$ & & \\
\hline Leeftijd & Interval & 41 & & $18-64$ & \\
\hline Geslacht & Nominaal & & & & \\
\hline Man & & 68 & $57 \%$ & & \\
\hline Vrouw & & 51 & $43 \%$ & & \\
\hline Burgerlijke staat & Nominaal & & & & \\
\hline Alleenstaand & & 35 & $30 \%$ & & \\
\hline Getrouwd & & 61 & $51 \%$ & & \\
\hline Gescheiden & & 23 & $19 \%$ & & \\
\hline Opleiding & Nominaal & & & & \\
\hline Lagere school & & 6 & $5 \%$ & & \\
\hline Middelbare school & & 73 & $61 \%$ & & \\
\hline $\mathrm{MBO}$ & & 8 & $7 \%$ & & \\
\hline $\mathrm{HBO}$ & & 12 & $10 \%$ & & \\
\hline WO & & 20 & $17 \%$ & & \\
\hline Werk & Nominaal & & & & \\
\hline Ja & & 33 & $28 \%$ & & \\
\hline Nee & & 67 & $56 \%$ & & \\
\hline Vrijwillig & & 19 & $16 \%$ & & \\
\hline Volgen traject & Nominaal & & & & \\
\hline Ja & & 50 & $42 \%$ & & \\
\hline Nee & & 69 & $58 \%$ & & \\
\hline Studie & Nominaal & 41 & $35 \%$ & & \\
\hline Bezig & & 73 & $61 \%$ & & \\
\hline Geen & & 5 & $4 \%$ & & \\
\hline Integratiepatroon & Nominaal & & & & \\
\hline Integratie & Nominaal & 93 & $78 \%$ & & \\
\hline Assimilatie & & 15 & $13 \%$ & & \\
\hline Separatie & & 6 & $5 \%$ & & \\
\hline Marginalisatie & & 5 & $4 \%$ & & \\
\hline
\end{tabular}


Bijlage 3 tabel 2: Overzicht van de mening over het verschil tussen de mate van emotionaliteit tussen Iraniërs en Nederlanders, aantallen en percentages. $\mathbf{N}=119$.

\begin{tabular}{lcccc}
$\begin{array}{l}\text { Iraniër veel } \\
\text { emotioneler }\end{array}$ & $\begin{array}{c}\text { Iraniër beetje } \\
\text { emotioneler }\end{array}$ & Gelijke & $\begin{array}{c}\text { Nederlander veel } \\
\text { emotioneler }\end{array}$ & $\begin{array}{c}\text { Nederlander beetje } \\
\text { emotioneler }\end{array}$ \\
\hline $69(58 \%)$ & $36(30 \%)$ & $9(8 \%)$ & $3(2 \%)$ & $2(2 \%)$
\end{tabular}

Bijlage 3 tabel 3: Overzicht van de schalen van de HTQ, de PSS en de genormeerde scores van de SCL-90 en de coping vragenlijst ( de UCL) van onderzoek 3 voor de groep vluchtelingen en pardonregeling met gemiddelde en spreiding van schalen, $\mathrm{N}=119$

\begin{tabular}{lccccc} 
Vragenlijst & Gemiddeld & Minimaal & Maximaal & SD & N \\
\hline HTQ (totaal) & 2.08 & 0 & 54 & 11 & 119 \\
DSM & 1.93 & .8 & 3.37 & 6.5 & 119 \\
PSS & 18.86 & .0 & 56 & 13.14 & 118
\end{tabular}

SCL-90

$\begin{array}{llllll}\text { ANG } & 5.39 & 1 & 7 & 1.5 & 119 \\ \text { AGO } & 5.28 & 1 & 7 & 1.84 & 119 \\ \text { DEP } & 6.00 & 1 & 7 & 1.15 & 119 \\ \text { SOM } & 5.03 & 1 & 7 & 1.96 & 119 \\ \text { IN } & 5.63 & 1 & 7 & 1.48 & 119 \\ \text { SEN } & 5.71 & 1 & 7 & 1.48 & 119 \\ \text { HOS } & 5.86 & 1 & 7 & 1.151 & 119 \\ \text { SLA } & 5.5 & 1 & 7 & 1.32 & 119 \\ \text { PSY } & 5.82 & 1 & 7 & 1.57 & 119 \\ \text { UCL } & & & & & \\ \text { AC } & 3.00 & 1 & 5 & .911 & 119 \\ \text { PAL } & 3.40 & 1 & 5 & .816 & 119 \\ \text { VER } & 3.31 & 1 & 5 & .861 & 119 \\ \text { SOC } & 3.29 & 1 & 5 & .877 & 119 \\ \text { PAS } & 4.00 & 1 & 5 & .893 & 119 \\ \text { EXP } & 3.43 & 1 & 5 & .829 & 119 \\ \text { GER } & 3.71 & 1 & 5 & .915 & 119\end{array}$




\section{Bijlage 4}

Bijlage 4 tabel 1: $t$-toets voor de HTQ, de PSS en de genormeerde scoren van de SCL-90 en de UCL: verschil tussen en pardonregeling $N=55$ en ex-vluchtelingen $N=64$, onderzoek $3 . N=119$.

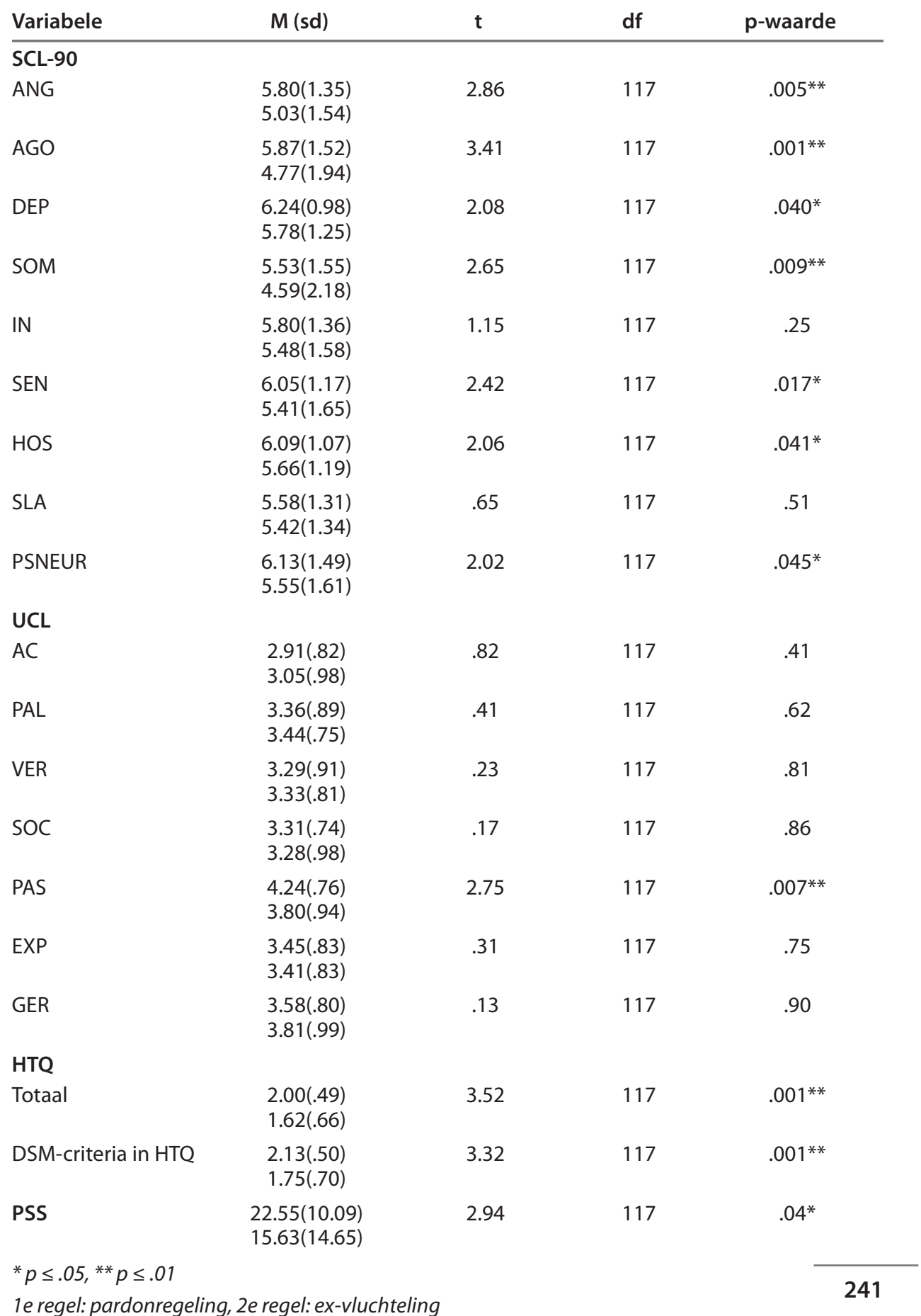


Bijlage 4 tabel 2: Correlatie tussen leeftijd, de HTQ, de PSS en de genormeerde scores van de SCL-90 en de UCL, $\mathrm{N}=119$.

\begin{tabular}{|c|c|c|c|c|c|c|c|c|c|c|c|c|}
\hline Variabele & Age & $A C$ & PAS & VER & PAL & SOC & EXP & GER & $\mathrm{SCL}$ & HTQ & DSM & PSS \\
\hline \multicolumn{13}{|l|}{ leeftijd } \\
\hline$A C$ & .050 & & & & & & & & & & & \\
\hline PAS & .019 & $-.21^{*}$ & & & & & & & & & & \\
\hline VER & -.030 & $.35^{* *}$ & .12 & & & & & & & & & \\
\hline PAL & .063 & $.19^{*}$ & $.20^{*}$ & $.29 * *$ & & & & & & & & \\
\hline SOC & -.11 & .15 & $.22^{*}$ & .14 & .10 & & & & & & & \\
\hline EXP & -.044 & .043 & .16 & .061 & .043 & $.46^{* *}$ & & & & & & \\
\hline GER & -.057 & $.50^{* *}$ & -.16 & .17 & $.24^{* *}$ & .077 & .056 & & & & & \\
\hline SCL-90 & .021 & $-.21^{*}$ & $.63^{* *}$ & .079 & $.20^{*}$ & .13 & .066 & -.15 & & & & \\
\hline HTQ totaal & .12 & -.096 & $.42^{* *}$ & .021 & .053 & .095 & -.036 & -.14 & $.50 * *$ & & & \\
\hline $\begin{array}{l}\text { DSMscores } \\
\text { in HTQ }\end{array}$ & .16 & -.067 & $.52^{* *}$ & .044 & .078 & .14 & .062 & -.19 & $.52^{* *}$ & $.85^{* *}$ & & \\
\hline PSS & .056 & $-.21^{*}$ & $.51^{* *}$ & .13 & .13 & .047 & .026 & $-.12^{*}$ & $.57^{* *}$ & $.62^{* *}$ & $.70^{* *}$ & \\
\hline
\end{tabular}

Bijlage 4 tabel 3: Correlatie tussen leeftijd en de genormeerde scores van de SCL-90, $N=119$.

\begin{tabular}{|c|c|c|c|c|c|c|c|c|c|c|}
\hline Variabele & Age & Ang & Ago & Dep & Som & In & Sen & Hos & Sla & PSN \\
\hline \multicolumn{11}{|l|}{ Age } \\
\hline Ang & -.051 & & & & & & & & & \\
\hline Ago & -.041 & $.65^{* *}$ & & & & & & & & \\
\hline Dep & .087 & $.75^{* * *}$ & $.50^{* *}$ & & & & & & & \\
\hline Som & .077 & $.76^{* *}$ & $.55^{* *}$ & $.62^{* *}$ & & & & & & \\
\hline In & .008 & $.69^{* * *}$ & $.51^{* *}$ & $.73^{* *}$ & $.61^{* *}$ & & & & & \\
\hline Sen & .023 & $.71^{* *}$ & $.49^{* *}$ & $.70^{* *}$ & $.56^{* *}$ & $.57^{* *}$ & & & & \\
\hline Hos & -.11 & $.61^{* *}$ & $.51^{* *}$ & $.48^{* *}$ & $.49^{* *}$ & $.52^{* *}$ & $.52^{* *}$ & & & \\
\hline Sla & .036 & $.58^{* *}$ & $.29 * *$ & $.49^{* *}$ & $.44^{*}$ & $.42^{* *}$ & $.42^{* *}$ & $.40^{* *}$ & & \\
\hline PSN & .021 & $.79 * *$ & $.57^{* *}$ & $.71^{* *}$ & $.72^{* *}$ & $.70^{* *}$ & $.70^{* *}$ & $.58^{* *}$ & $.56^{* *}$ & \\
\hline \multicolumn{11}{|c|}{${ }^{*} p \leq .05,{ }^{* *} p \leq .01$} \\
\hline
\end{tabular}


Bijlage 4 tabel 4: t-toets voor de HTQ, de PSS en de genormeerde scores van de SCL-90 en de UCL: verschil tussen mannen $\mathrm{N}=69$ en vrouwen $\mathrm{N}=50$ voor de hele groep. $\mathrm{N}=119$.

\begin{tabular}{|c|c|c|c|c|}
\hline Variabele & $M(s d)$ & $t$ & $\mathrm{~N}$ & Significante (tweezijdig) \\
\hline \multicolumn{5}{|l|}{ SCL-90 } \\
\hline ANG & $\begin{array}{l}5.43(1.41) \\
5.32(1.620\end{array}$ & .41 & 119 & .68 \\
\hline AGO & $\begin{array}{l}5.49(1.56) \\
4.98(2.14)\end{array}$ & 1.50 & 119 & .13 \\
\hline DEP & $\begin{array}{l}6.00(1.05) \\
5.98(1.28)\end{array}$ & .093 & 119 & .92 \\
\hline SOM & $\begin{array}{l}5.03(1.97) \\
5.02(1.96)\end{array}$ & .025 & 119 & .98 \\
\hline IN & $\begin{array}{l}5.59(1.48) \\
5.68(1.50)\end{array}$ & .30 & 119 & .75 \\
\hline SEN & $\begin{array}{l}5.75(1.40) \\
5.64(1.60)\end{array}$ & .41 & 119 & .68 \\
\hline HOS & $\begin{array}{l}5.71(1.17) \\
6.06(1.11)\end{array}$ & 1.60 & 119 & .10 \\
\hline SLA & $\begin{array}{l}5.57(1.19) \\
5.40(1.49)\end{array}$ & .66 & 119 & .50 \\
\hline PSNEUR & $\begin{array}{l}5.71(1.71) \\
5.96(1.37)\end{array}$ & .85 & 119 & .39 \\
\hline \multicolumn{5}{|l|}{ UCL } \\
\hline$A C$ & $\begin{array}{l}2.74(.96) \\
3.32(.71)\end{array}$ & 3.60 & 119 & $<.001^{* *}$ \\
\hline PAL & $\begin{array}{l}3.28(.82) \\
3.58(.78)\end{array}$ & 2.04 & 119 & $.044^{*}$ \\
\hline VER & $\begin{array}{l}3.17(.87) \\
3.50(.81)\end{array}$ & 2.07 & 119 & $.041^{*}$ \\
\hline SOC & $\begin{array}{l}3.26(.88) \\
3.34(.87)\end{array}$ & .48 & 119 & .62 \\
\hline PAS & $\begin{array}{l}4.07(.89) \\
3.90(.88)\end{array}$ & 1.04 & 119 & .30 \\
\hline EXP & $\begin{array}{l}3.39(.86) \\
3.48(.78)\end{array}$ & .57 & 119 & .56 \\
\hline GER & $\begin{array}{l}3.67(.96) \\
3.76(.84)\end{array}$ & .54 & 119 & .58 \\
\hline \multicolumn{5}{|l|}{ HTQ } \\
\hline Totaal & $\begin{array}{l}1.78(.62) \\
1.81(.62)\end{array}$ & .92 & 119 & .35 \\
\hline DSM & $\begin{array}{l}1.93(.67) \\
1.92(.62)\end{array}$ & .096 & 119 & .92 \\
\hline PSS & $\begin{array}{l}19.25(13.63) \\
18.31(12.54)\end{array}$ & .38 & 119 & .70 \\
\hline
\end{tabular}

${ }^{*} p \leq .05,{ }^{* *} p \leq .01$

1e regel: man, 2e regel: vrouw 


\section{Bijlage 5: Onderzoek 1}

Bijlage 5 figuur 1: Scree Plot afhankelijke variabele tevredenheid

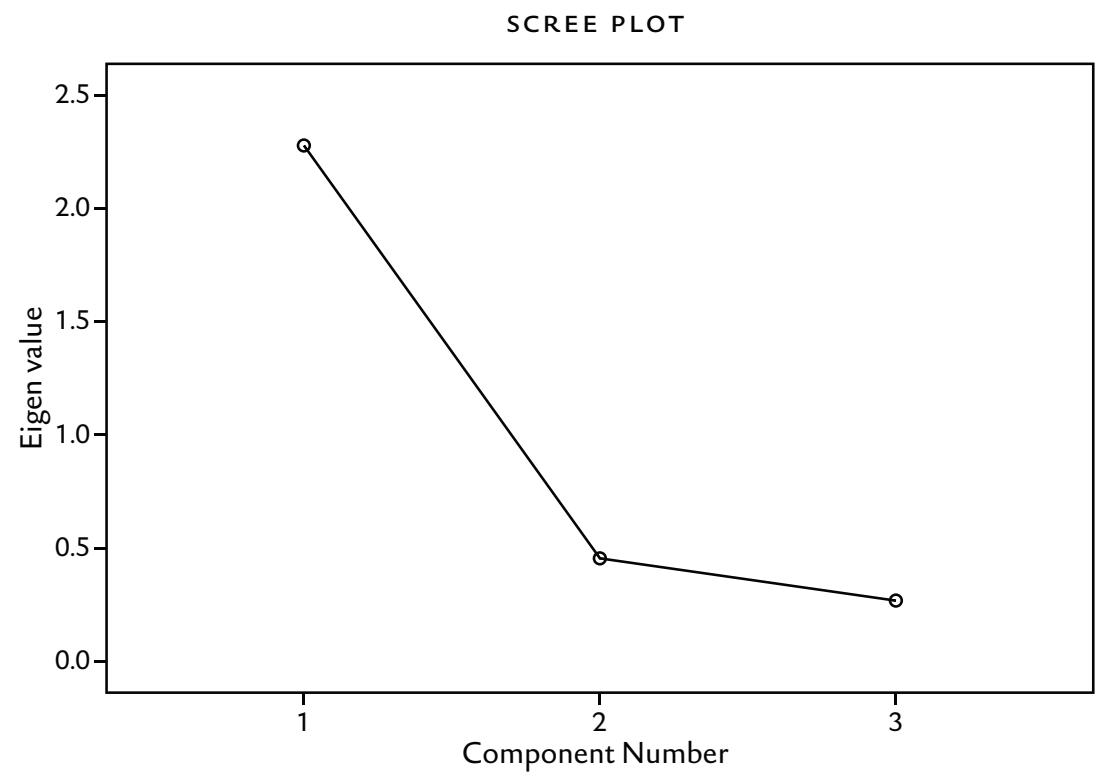

Principale Componentenanalyse met Orthogonale rotatie voor tevredenheid met drie begeleidingsvariabelen (inspraak, rechtvaardigheid, vertrouwen). 


\section{Bijlage 5 figuur 2: Scree Plot variabele psychopathologie}

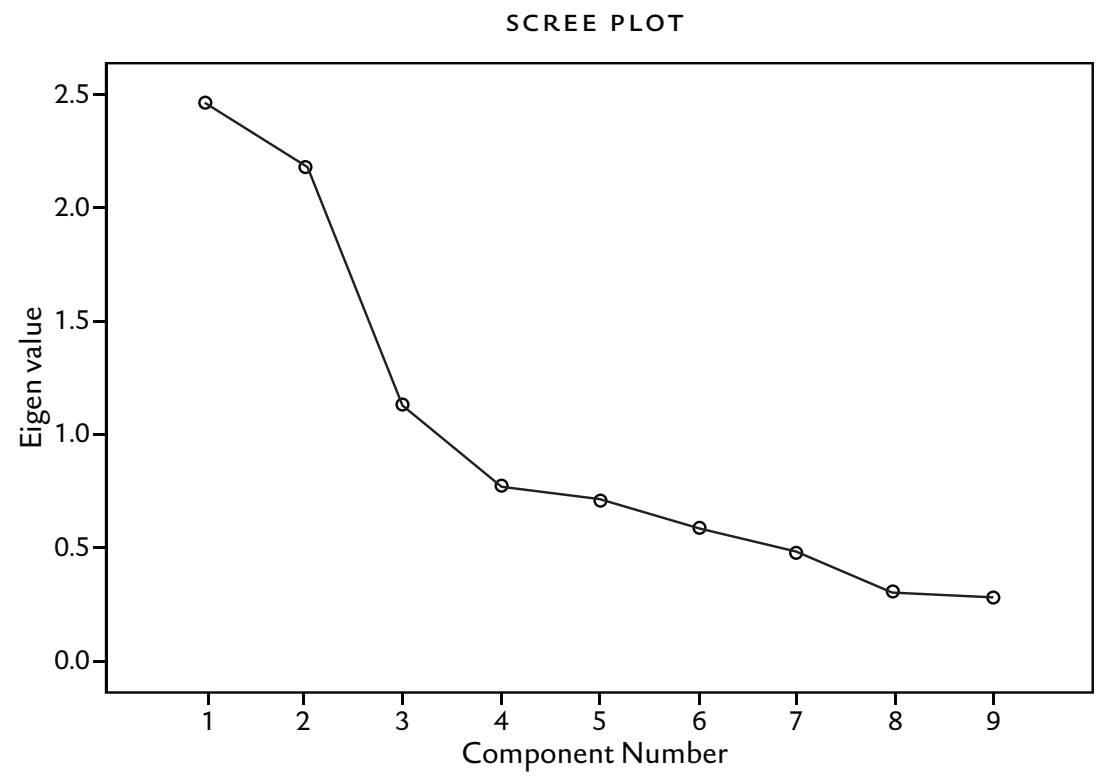

Principale Componentenanalyse met Orthogonale rotatie voor psychopathologie met de BDI-score, totale SCL-90-score en de UCL-scores . 


\section{Afkortingenlijst}

A-status Vluchtelingenstatus

Azc Asielzoekerscentrum

BDI Beck Depression Inventory

CBS Centraal Bureau voor de Statistiek

COA Centraal Orgaan opvang asielzoekers

COTAN Commissie Testaangelegenheden Nederland

CWI Centrum van Werk en Inkomen

D-document Verstrekt aan vluchtelingen die vanwege klemmende redenen van humanitaire aard in Nederland mogen blijven

DSM-IV Diagnostic and Statistical Manual for Mental Disorders (vierde editie)

HTQ Harvard Trauma Questionnaire

IND Immigratie- en Naturalisatiedienst

MOA Medische Opvang Asielzoekers

OC Tijdelijke verblijfplaats waar asielzoekers drie maanden verblijven

PSS PTSS Symptom Scale

PTSS Posttraumatische stressstoornis

ROA Regeling Opvang Asielzoekers

ROC Regionaal Opleidingen Centrum

SCL-90 90-items Symptom Checklist:

ANG Angst in SCL-90

AGO Agorafobie in SCL-90

DEP Depressie in SCL-90 
SOM Somatisatie in SCL-90

IN Insufficiëntie van denken en handelen in SCL-90

HOS Hostiliteit in SCL-90

SLA Slaapproblemen in SCL-90

PSNEUR Psychoneuroticisme in SCL-90

UAF Stichting voor Vluchteling-Studenten

UCL Utrechtse Copinglijst:

AC Actief aanpakken in UCL

PAL Palliatieve coping in UCL

VER Vermijdende, afwachtende coping in UCL

SOC Sociale steun zoeken in UCL

PAS Passief reactief patroon in UCL

EX Expressie van gevoelens in UCL

GER Geruststellende gedachten

UNHCR United Nations High Commissioner for Refugees

VVA-BT Verblijfsvergunning voor Asiel-Bepaalde Tijd

VVA-OT Verblijfsvergunning voor Asiel-Onbepaalde Tijd

WHO World Health Organization

WI Wet inburgering

WIN Wet Inburgering Nieuwkomers

WODC Wetenschappelijk Onderzoeks- en Documentatie Centrum

WRR Wetenschappelijke Raad voor het Regeringsbeleid 


\section{Lijst met afbeeldingen (tabellen en figuren)}

$\begin{array}{ll}\text { Figuur } 1.1 \text { Het onderzoeksmodel } & 14\end{array}$

Tabel 3.1 Het Interactieve Acculturatie Model (IAM) $\quad 40$

Tabel 9.1 Vergelijking enkele kenmerken van de onderzoeksgroep met het landelijke CBS-onderzoek naar Iraniërs in Nederland in percentages (CBS, 2004) 103

Tabel 9.2 Algemene gegevens van de respondenten 111

Figuur 9.3 Interactiepatronen op basis van de twee dimensies van Leary: affiliatie (tegen-samen) $\begin{array}{ll}\text { en controle (boven-onder). Ontleend aan Leary (1957) } & 114\end{array}$

$\begin{array}{ll}\text { Tabel } 9.4 \text { Overzicht van de stappen van de gegevensverwerking } & 123\end{array}$

Tabel 9.5 Vergelijking van enkele kenmerken van de onderzoeksgroep met het landelijke onderzoek in percentage (CBS, 2007-2008)

Tabel 10.1 Inschatting van de respondenten (148) van hun kansen op positieverbetering door begeleiding

Tabel 10.2 Vergelijking van de gegevens (1): gemiddelde, standaarddeviatie en p-waarde van de onderzoeksgroep en de normale populatie

Tabel 10.3 SCL-90: de resultaten van de uitslagen van de respondenten $(\mathrm{N}=148)$

Tabel 10.4 Beck Depressie-vragenlijst: de resultaten van de uitslagen van de respondenten $(\mathrm{N}=148)$

Tabel 10.5 Utrechtse Copingvragenlijst (UCL): de resultaten van de uitslagen van de respondenten $(\mathrm{N}=148)$

Figuur 10.6 Scree Plot-1

Figuur 10.7 Scree Plot-2

Tabel 10.8 Regressieanalyse met kansperceptie als afhankelijke variabele, tevredenheid, actieve- gedragsmatige coping, expressieve coping en psychopathologie als onafhankelijke variabelen en het effect van verblijfsvergunning

Tabel 10.9 De overige interactie-effecten van de onafhankelijke variabelen met de variabele tevredenheid

Figuur 10.10 Profile Plot van de kansperceptie bij interactie-effect van leeftijd en tevredenheid

Tabel 10.11 Vergelijking van de gegevens: gemiddelde, standaarddeviatie t-toets en $p$-waarde van de onderzoeksgroep en de normale populatie 
Tabel 10.13 PTSS-vragenlijsten: (HTQ, PSS)-uitslagen van de 119 respondenten in percentages

Tabel 10.14 Utrechtse Copingvragenlijst (UCL): uitslagen van de 119 respondenten

Bijlage 1 tabel 1: Overzicht van de gegevens van respondenten en het integratiepatroon van onderzoek 1 voor de gehele groep met gemiddelde en spreiding.

Bijlagen 1 tabel 2: Overzicht van de mate van de beoordeling van emotionaliteit en zakelijkheid tussen twee landen, aantallen en percentages: $N=148$.

Bijlage 1 tabel 3: Overzicht van de originele schalen van variabele kansperceptie, tevredenheid, begeleidingsvariabelen en de genormeerde scores van de BDI, de SCL-90 en de UCL van onderzoek 1 (ex-vluchtelingen en asielzoekers) met gemiddelde en spreiding van variabelen.

Bijlage 2 tabel 1: Correlaties tussen de variabele kansperceptie en begeleidingsvariabelen, $\mathrm{N}=148$.

Bijlage 2 tabel 2: Correlaties tussen de variabele kansperceptie en de genormeerde scores van de SCL-90, $\mathrm{N}=148$.

Bijlage 2 tabel 3: Correlatie tussen de variabele kansperceptie en de genormeerde scores van de UCL, $\mathrm{N}=148$.

Bijlage 2 tabel 4: t-toets voor variabelen kansperceptie, vertrouwen, inspraak, rechtvaardigheid en de genormeerde scores van de BDI, de SCL-90 en de UCL tussen asielzoekers (ex) vluchtelingen. 238

Bijlage 3 tabel 1: Algemene informatie en het integratiepatroon van onderzoek 3 voor de gehele groep met gemiddelde en spreiding.

Bijlage 3 tabel 2: Overzicht van de mening over het verschil tussen de mate van emotionaliteit tussen Iraniërs en Nederlanders, aantallen en percentages. $\mathrm{N}=119$.

Bijlage 3 tabel 3: Overzicht van de schalen van de HTQ, de PSS en de genormeerde scores van de SCL-90) en de coping vragenlijst (de UCL) van onderzoek 3 voor de groep vluchtelingen en pardonregeling met gemiddelde en spreiding van schalen, $\mathrm{N}=119$.

Bijlage 4 tabel 1: t-toets voor de HTQ, de PSS en genormeerde scoren van de SCL-90 en de UCL: verschil tussen en pardonregeling $(n=55)$ en ex-vluchtelingen $(n=64)$.

Bijlage 4 tabel 2: Correlatie tussen leeftijd, de HTQ, de PSS en de genormeerde scores van de SCL-90 en de $\mathrm{UCL}, \mathrm{N}=119$.

Bijlage 4 tabel 3: Correlatie tussen leeftijd en de genormeerde scores van de SCL-90, N =119.

Bijlage 4 tabel 4: t-toets voor de HTQ, de PSS en de genormeerde scores van de SCL-90 en de UCL: verschil tussen mannen $\mathrm{N}=69$ en vrouwen $\mathrm{N}=50$ voor de hele groep. $\mathrm{N}=119$.

Bijlage 5 figuur 1: Scree Plot afhankelijke variabele tevredenheid 


\section{Begeleidingsvragenlijst (deel B)}

\section{Deel I: Hoe ervaart u de begeleiding?}

De onderstaande vragen hebben betrekking op diverse soorten van uw begeleiding, bijvoorbeeld gezondheidszorg, onderwijs en werk.

1 Door de begeleiding wordt de kans op werk groter dan zonder begeleiding.

2 Door de begeleiding wordt de kans dat mijn lichamelijke gezondheid op peil blijft groter dan zonder begeleiding.

3 Door de begeleiding is de kans dat mijn psychische gezondheid op peil blijft groter dan zonder begeleiding.

4 Door de begeleiding is de kans om mijn financiële situatie te verbeteren groter dan zonder begeleiding.

5 Door de begeleiding is de kans dat ik meer beroepsvaardigheden kan verwerven groter dan zonder begeleiding.

6 Door de begeleiding wordt de kans dat ik meer zelfvertrouwen krijg groter dan zonder begeleiding.
1-Geheel mee eens

2-Enigszins mee eens

3-Geen mening

4-Enigszins mee oneens

5-Geheel mee oneens

1-Geheel mee eens

2-Enigszins mee eens

3-Geen mening

4-Enigszins mee oneens

5-Geheel mee oneens

1-Geheel mee eens

2-Enigszins mee eens

3-Geen mening

4-Enigszins mee oneens

5-Geheel mee oneens

1-Geheel mee eens

2-Enigszins mee eens

3-Geen mening

4-Enigszins mee oneens

5-Geheel mee oneens

1-Geheel mee eens

2-Enigszins mee eens

3-Geen mening

4-Enigszins mee oneens

5-Geheel mee oneens

1-Geheel mee eens

2-Enigszins mee eens

3-Geen mening

4-Enigszins mee oneens

5-Geheel mee oneens 
7 Door de begeleiding wordt de kans op meer sociale contacten groter dan zonder begeleiding.

8 Door de begeleiding wordt de kans op werk dat beter aansluit bij mijn persoonlijke wensen en voorkeuren groter dan zonder begeleiding.

9 Door de begeleiding wordt de kans op werkaanbiedingen groter dan zonder begeleiding.

10 Door de begeleiding wordt de kans op een vaste baan groter dan zonder begeleiding.

11 Door de begeleiding is de kans dat ik mijn situatie verbeter groter dan zonder begeleiding.

12 Door de begeleiding is de kans dat ik het verschil tussen de Iraanse en de Nederlandse cultuur kan overbruggen groter dan zonder begeleiding.
1-Geheel mee eens

2-Enigszins mee eens

3-Geen mening

4-Enigszins mee oneens

5-Geheel mee oneens

1-Geheel mee eens

2-Enigszins mee eens

3-Geen mening

4-Enigszins mee oneens

5-Geheel mee oneens

1-Geheel mee eens

2-Enigszins mee eens

3-Geen mening

4-Enigszins mee oneens

5-Geheel mee oneens

1-Geheel mee eens

2-Enigszins mee eens

3-Geen mening

4-Enigszins mee oneens

5-Geheel mee oneens

1-Geheel mee eens

2-Enigszins mee eens

3-Geen mening

4-Enigszins mee oneens

5-Geheel mee oneens

1-Geheel mee eens

2-Enigszins mee eens

3-Geen mening

4-Enigszins mee oneens

5-Geheel mee oneens 


\section{Deel II: Hoe ervaart u de begeleiding?}

De onderstaande vragen hebben betrekking op diverse soorten van uw begeleiding, bijvoorbeeld gezondheidszorg, onderwijs en werk.

13 Het systeem van begeleiding bezorgt iedere vluchteling evenveel kansen.

14 Mijn begeleider behandelt iedere vluchteling op dezelfde manier.

15 Over het geheel genomen is de informatie die ik van mijn begeleider krijg/kreeg zorgvuldig en juist.

16 Mogelijke klachten over de begeleiding worden door het systeem van begeleiding altijd zorgvuldig behandeld.

17 Mogelijke klachten over de begeleiding worden door mijn begeleider altijd zorgvuldig behandeld.

18 Het systeem van begeleiding houdt rekening met mijn levenshouding (bijvoorbeeld godsdienst, mening, behoeftes).

19 Mijn begeleider houdt rekening met mijn levenshouding (bijvoorbeeld godsdienst, mening, behoeftes).
1-Geheel mee eens

2-Enigszins mee eens

3-Geen mening

4-Enigszins mee oneens

5-Geheel mee oneens

1-Geheel mee eens

2-Enigszins mee eens

3-Geen mening

4-Enigszins mee oneens

5-Geheel mee oneens

1-Geheel mee eens

2-Enigszins mee eens

3-Geen mening

4-Enigszins mee oneens

5-Geheel mee oneens

1-Geheel mee eens

2-Enigszins mee eens

3-Geen mening

4-Enigszins mee oneens

5-Geheel mee oneens

1-Geheel mee eens

2-Enigszins mee eens

3-Geen mening

4-Enigszins mee oneens

5-Geheel mee oneens

1-Geheel mee eens

2-Enigszins mee eens

3-Geen mening

4-Enigszins mee oneens

5-Geheel mee oneens

1- Geheel mee eens

2-Enigszins mee eens

3-Geen mening

4-Enigszins mee oneens

5-Geheel mee oneens 
20 Het systeem van begeleiding is eerlijk en fair.

21 Mijn begeleider is eerlijk.

22 Begeleiding heeft mijn positie/situatie vergeleken met andere vluchtelingen verbeterd.

23 Begeleiding heeft mijn positie/situatie vergeleken met mijn vroegere situatie verbeterd.
1-Geheel mee eens

2-Enigszins mee eens

3-Geen mening

4-Enigszins mee oneens

5-Geheel mee oneens

1-Geheel mee eens

2-Enigszins mee eens

3-Geen mening

4-Enigszins mee oneens

5-Geheel mee oneens

1-Geheel mee eens

2-Enigszins mee eens

3-Geen mening

4-Enigszins mee oneens

5-Geheel mee oneens

1-Geheel mee eens

2-Enigszins mee eens

3-Geen mening

4-Enigszins mee oneens

5-Geheel mee oneens

24 Begeleiding heeft mijn positie ten opzichte van wat ik zelf steeds wil/wilde verbeterd.
1-Geheel mee eens

2-Enigszins mee eens

3-Geen mening

4-Enigszins mee oneens

5-Geheel mee oneens 


\section{Deel III: Hoe ervaart u uw begeleiding?}

Wat is uw ervaring met het verkrijgen van informatie, met vertrouwen, inspraak, respect en discriminatie? Deze vragen kunnen betrekking hebben op verschillende soorten van uw begeleiding, bijvoorbeeld gezondheidszorg, onderwijs, werk.

$25 \mathrm{lk}$ kan veel invloed uitoefenen op de begeleiding.

$26 \mathrm{lk}$ ben in grote mate zelf verantwoordelijk voor het resultaat van de begeleiding.

27 Ik word heel goed op de hoogte gesteld van de mogelijkheden van de begeleiding.

$28 \mathrm{lk}$ kan tijdens de gesprekken met mijn begeleider mijn ideeën en gevoelens uiten.

29 Mijn begeleider weet goed wat er bij mij leeft.

$30 \mathrm{lk}$ heb veel vertrouwen in de wijze waarop de begeleider mij adviseert.

$31 \mathrm{lk}$ heb veel vertrouwen in wat de begeleider voor mij kan bereiken.
1-Geheel mee eens

2-Enigszins mee eens

3-Geen mening

4-Enigszins mee oneens

5-Geheel mee oneens

1-Geheel mee eens

2-Enigszins mee eens

3-Geen mening

4-Enigszins mee oneens

5-Geheel mee oneens

1-Geheel mee eens

2-Enigszins mee eens

3-Geen mening

4-Enigszins mee oneens

5-Geheel mee oneens

1-Geheel mee eens

2-Enigszins mee eens

3-Geen mening

4-Enigszins mee oneens

5-Geheel mee oneens

1-Geheel mee eens

2-Enigszins mee eens

3-Geen mening

4-Enigszins mee oneens

5-Geheel mee oneens

1-Geheel mee eens

2-Enigszins mee eens

3-Geen mening

4-Enigszins mee oneens

5-Geheel mee oneens

1-Geheel mee eens

2-Enigszins mee eens

3-Geen mening

4-Enigszins mee oneens

5-Geheel mee oneens 
$32 \mathrm{lk}$ heb veel vertrouwen in de resultaten van de begeleiding.

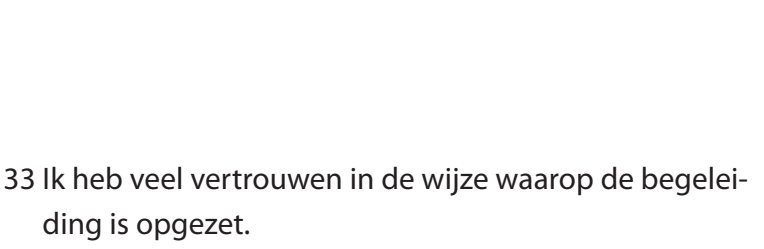

34 Het systeem van begeleiding discrimineert mensen niet op basis van hun persoonlijke kenmerken zoals hun geloof, ras, afkomst en geslacht.

35 Mijn begeleider discrimineert mensen niet op basis van hun persoonlijke kenmerken zoals hun geloof, ras, afkomst en geslacht.

$36 \mathrm{lk}$ ben van mening dat mijn begeleider rekening houdt met mijn ideeën doordat hij/zij zich in mij als persoon heeft verdiept.

$37 \mathrm{lk}$ ben van mening dat mijn begeleider rekening houdt met mijn ideeën doordat hij/zij zich betrokken voelt bij mij.

$38 \mathrm{lk}$ ben van mening dat mijn begeleider rekening houdt met mijn ideeën doordat hij/zij mij begrijpt en ondersteunt.

$39 \mathrm{lk}$ ben van mening dat mijn begeleider rekening houdt met mijn ideeën doordat hij/zij alles zakelijk en afstandelijk opvat.
1-Geheel mee eens

2-Enigszins mee eens

3-Geen mening

4-Enigszins mee oneens

5-Geheel mee oneens

1-Geheel mee eens

2-Enigszins mee eens

3-Geen mening

4-Enigszins mee oneens

5-Geheel mee oneens

1-Geheel mee eens

2-Enigszins mee eens

3-Geen mening

4-Enigszins mee oneens

5-Geheel mee oneens

1-Geheel mee eens

2-Enigszins mee eens

3-Geen mening

4-Enigszins mee oneens

5-Geheel mee oneens

1-Geheel mee eens

2-Enigszins mee eens

3-Geen mening

4-Enigszins mee oneens

5-Geheel mee oneens

1-Geheel mee eens

2-Enigszins mee eens

3-Geen mening

4-Enigszins mee oneens

5-Geheel mee oneens

1-Geheel mee eens

2-Enigszins mee eens

3-Geen mening

4-Enigszins mee oneens

5-Geheel mee oneens

1-Geheel mee eens

2-Enigszins mee eens

3-Geen mening

4-Enigszins mee oneens

5-Geheel mee oneens 
$40 \mathrm{lk}$ ben van mening dat mijn begeleider goed naar me luistert en bij het nemen van beslissingen rekening houdt met mijn ideeën en meningen.
1-Geheel mee eens

2-Enigszins mee eens

3-Geen mening

4-Enigszins mee oneens

5-Geheel mee oneens 